Award Number

DE-FC36-07GO17109

\title{
Evaluation of the Potential Environmental Impacts from Large-Scale Use and Production of Hydrogen in Energy and Transportation Applications
}

\section{Final Report}

\author{
Recipient \\ University of Illinois \\ Principal Investigator \\ Donald J. Wuebbles \\ (University of Illinois)
}

\begin{abstract}
Working Partners
Manvendra K. Dubey (Los Alamos National Laboratory), Jae Edmonds (Pacific Northwest National Laboratory), David Layzell (Queen's University, Canada), Seth Olsen (University of Illinois), Thom Rahn (Los Alamos National Laboratory), Angus Rocket (University of Illinois), Dong Wang (University of Illinois), Wenjing Jia
\end{abstract} (University of Illinois)

\section{Contact}

Dr. Donald Wuebbles, Phone: 217-244-1568, wuebbles@uiuc.edu

\section{DOE Managers}

Fred Joseck, Katie Randolph 


\section{Table of Contents}

Executive Summary ................................................ page 3

Acknowledgments ................................................. page 10

Emissions Scenario Development ............................... Section 1 (page 11)

Tropospheric Impact Assessment ............................... Section 2 (page 37)

Stratospheric Ozone Impact Assessment ....................... Section 3 (page 91)

Regional Air Quality Impact Assessment ................... Section 4 (page 127)

$\mathrm{H}_{2}$ Microbial Adaptive Soil Sink Assessment ............... Section 5 (page 161)

Integrated Assessment Model .......................................Section 6 (page 167)

Oxygen Plume Risk Assessment ..................................Section 7 (page 177)

Metal Embrittelment Risk Assessment ....................... Section 8 (page 183) 


\section{Executive Summary}

\section{Project Objective:}

The purpose of this project was to systematically identify and examine possible near and long-term ecological and environmental impacts from the use of hydrogen in future road transportation and power applications. The project involved modeling, data analysis and some field and laboratory experiments. This project was aimed at an end-to-end analysis of the potential ecological and environmental impacts of transitioning to a hydrogen-based road transportation sector.

\section{Background:}

There is limited quantitative understanding of the projected market penetration, the changes in emissions avoided or gained upon transitioning to hydrogen-based systems, and on the resulting impacts on the environment. Our project team is composed of scientists, engineers, and economists that have the right blend of expertise and tools to appropriately attack the issues we will face in this assessment.

The specific objectives include analyses to address the following:

- Impact of hydrogen releases on the oxidative capacity of the atmosphere

- Long-term stability of the ozone layer due to changes in hydrogen emissions

- Impact of hydrogen emissions and resulting concentrations on atmospheric chemistry and climate

- Impact on microbial ecosystems involved in hydrogen uptake

- Role of biological impacts in causing indirect effects on the atmosphere and climate 
- Criteria pollutants emitted given different scenarios of vehicle market penetration

- Impact of criteria pollutants on human health, air quality, ecosystems and structures under different penetration scenarios

Using a state-of-the-art model of the energy-technology-economy system (MiniCAM) along with other analyses, we evaluated changes in emissions due to hydrogen technologies and uses. We evaluated the effects of hydrogen on all aspects of atmospheric chemistry and composition using state-of-the art three-dimensional global models of atmospheric chemistry and physics (models used: CAM-chem, CMAQ, MOZART). Through field and laboratory studies, we gained new insights into the relationships affecting soil uptake and the impacts on ecosystems. Analyses were carried out, under various assumptions of hydrogen concentrations, of the effect of the potential of hydrogen to degrade materials and structures.

\section{Summary of Future $\mathbf{H}_{2}$-Based Road Transportation Sector Impact Assessment Findings}

- High and low 2050 emissions scenarios that bracket possible future emissions were developed. Emissions scenarios were developed for 2050 based on the IPCC high-emitting A1FI and low-emitting B1 growth scenarios and two hydrogen technology adoption scenarios (fuel cell (FC) and internal combustion engine (ICE) technologies). Our basic assumptions are that the hydrogen for road transportation is produced cleanly and renewably, e.g., with wind, solar, or nuclear power, that all road-based transportation switches to $\mathrm{H}_{2}$, and that in 2050 the efficiency of fuel cells and internal combustion engines will be comparable. The implications of these assumptions as well as the sensitivity of the emissions to these assumptions are explored in the full 
report. With the adoption of an $\mathrm{H}_{2}$ based road transportation sector $\mathrm{H}_{2}$ emissions increase due to $\mathrm{H}_{2}$ leakage (by $\sim 4$ times for the A1FI and $\sim 7$ times for the $\mathrm{B} 1$ scenarios; however, the total $\mathrm{H}_{2}$ emissions increase only 1.8 times for the A1FI and 1.6 times for the B1 scenarios) and fossil fuel combustion related emissions decrease (e.g., $\mathrm{CO}$ decreases by $25 \%$ and $9 \%$ and NOx decreases by $29 \%$ and $24 \%$ for the A1FI and B1 scenarios, respectively). Even with the emissions changes the absolute emissions for the B1 scenarios are lower than those for any of the A1FI scenarios. There are still large uncertainties in future $\mathrm{H}_{2}$ emissions since these depend on many factors with large uncertainties, e.g., leakage rates, fuel cell and internal combustion engine efficiency improvements, and growth in population and energy demand. Our assumptions were conservatively chosen to represent the higher end and larger impact $\mathrm{H}_{2}$ emissions.

- There is a general improvement in tropospheric air quality with the adoption of an $\mathbf{H}_{2}$ fuel cell powered transportation sector. Annual mean global ozone burdens decrease by $7 \%$ and $1 \%$ for the A1FI-FC and A1FI-ICE scenarios and $5 \%$ and $1 \%$ for the B1-FC and B1-ICE scenarios. Summertime ozone concentrations decrease by $\sim 15 \mathrm{ppb}$ over population centers. The annual mean global CO burden decreases by $14 \%$ and $18 \%$ for the A1FI-FC and A1FI-ICE scenarios by $4 \%$ and $7 \%$ for the B1 scenarios. There are also substantial decreases in soot and sulfate aerosols. However, $\mathrm{H}_{2}$ burdens increase by $\sim 40 \%$ and $\sim 20 \%$ for the A1FI and B1 scenarios respectively. There is also a decrease of $\sim 4 \%$ in $\mathrm{OH}$ radical concentrations, and hence the oxidizing power of the troposphere, for both the A1FI and B1 fuel cell technology scenarios. $\mathrm{OH}$ concentrations actually increase by $7 \%$ and $3 \%$ for the A1FI-ICE and B1-ICE scenarios, respectively. For the A1FI-FC scenario about one half of the $\mathrm{OH}$ decrease is due to the $\mathrm{H}_{2}$ increase and the other half due to the changes in other fossil fuel combustion emissions and decrease in $\mathrm{O}_{3}$ concentration. The decrease in the oxidizing capacity of the troposphere 
could increase the lifetime of methane, a potent greenhouse gas. However, this trade off must be evaluated against the improvements in air quality and could be somewhat ameliorated by decreasing $\mathrm{H}_{2}$ leakage emissions. Though the adoption of an $\mathrm{H}_{2}$ based road transportation sector improves air quality to some degree for both $\mathrm{H}_{2}$ fuel cell and $\mathrm{H}_{2}$ internal combustion engine technology in both the A1Fi and B1 scenarios, for all of the gaseous pollutants the improvements due to the adoption of $\mathrm{H}_{2}$ as a fuel are smaller than those achieved by following the lower emitting B1 growth path instead of the higher emitting A1FI growth path.

- A Future $\mathrm{H}_{2}$ based road transportation sector may adversely impact stratospheric ozone but total ozone levels would still be higher than current levels due to recovery of CFC induced ozone loss. The impact of an $\mathrm{H}_{2}$-based road transportation sector on stratospheric ozone depends on the $\mathrm{H}_{2}$ scenario examined. Global annual mean stratospheric ozone burdens decrease by $0.5 \%$ for the A1FI-FC scenario, $0.2 \%$ for the A1FI-ICE and B1-FC scenario and increases by $0.04 \%$ for the B1-ICE scenario. The largest relative decreases generally occur in the tropical upper troposphere and lower stratosphere. These changes are caused by a combination of increased HOx concentrations and decreased NOx concentrations and the interaction between the HOx and NOx ozone chemistry. Put in context, the possible adverse impact on stratospheric ozone (up to $0.5 \%$ decrease) is considerably less than the $\sim 3 \%$ decrease throughout the 1980s and 1990s due to chlorofluorocarbon (CFC) caused ozone destruction. In addition by 2050 ozone levels likely will have substantially recovered from the CFC induced ozone loss and even with the possible ozone loss from the adoption of an $\mathrm{H}_{2}$ based road transportation sector, stratospheric ozone levels would be greater than they are today.

- Substantial improvements in U.S. regional air quality are possible for a future $\mathbf{H}_{2}$ based road transportation sector. There are substantial 
improvements in all of the key air quality indicators (e.g., $\mathrm{O}_{3}, \mathrm{NOx}, \mathrm{PM} 2.5$, $\mathrm{CO}, \mathrm{PAN}$ ) in a future fuel cell powered $\mathrm{H}_{2}$ based transportation sector. Most of these improvements occur during times of maximum concern about pollution thereby enhancing the efficacy of improvements in terms of regulatory and health impacts. For example, the largest $\mathrm{O}_{3}$ reductions occur during summertime when $\mathrm{O}_{3}$ concentrations are typically highest. Although there are many substantial uncertainties in predicting the future impacts of an $\mathrm{H}_{2}$ powered road transportation sector in 2050 some inferences appear to be robust. For all $\mathrm{H}_{2}$-FC scenarios substantial air quality improvements were observed. This robust conclusion is directly due to the emissions reductions and independent of growth scenario and season. The absolute air quality differences between the $\mathrm{A} 1 \mathrm{Fi}$ and $\mathrm{B} 1$ growth scenarios are typically larger than the differences between technology scenarios, e.g., the air quality in a B1 type scenario is generally better than in any A1Fi scenario regardless of $\mathrm{H}_{2}$ technology adoption or not. In other words, a societal move away from fossil fuel use to alternative energy and transportation choices is generally better for air quality than remaining heavily fossil fuel intensive. If $\mathrm{H}_{2}$-ICE technology is adopted there are relatively small improvements in some key air quality species, e.g., $\mathrm{O}_{3}$, NOx, PAN, and less improvement in PM 2.5 air quality than in the $\mathrm{H}_{2}-\mathrm{FC}$ technology case.

\section{- Enhanced $\mathrm{H}_{2}$ soil microbial uptake may mitigate future $\mathrm{H}_{2}$ concentration} increases. Soil microbes play a major role in the global hydrogen $\left(\mathrm{H}_{2}\right)$ cycle, accounting for about $80 \%$ of the $\mathrm{H}_{2}$ removed from the current atmosphere. Our laboratory results suggest there would be a significant stimulatory effect on the $\mathrm{H}_{2}$ uptake by soils at increased atmospheric $\mathrm{H}_{2}$ concentrations expected with the adoption of an $\mathrm{H}_{2}$-based road transportation sector. In our simulations this decreases tropospheric $\mathrm{H}_{2}$ concentrations by over $20 \%$ over the nonenhanced sink. This negative feedback to increasing $\mathrm{H}_{2}$ concentrations would 
also tend to ameliorate the adverse impact of an $\mathrm{H}_{2}$ based road transportation sector on stratospheric ozone.

- An $\mathrm{H}_{2}$ integrated assessment model allows quick scientifically-based assessment of climate impacts. An integrated assessment model (IAM) has been developed to allow easy estimates of the impact of the adoption of an $\mathrm{H}_{2}$ powered road transportation sector. The IAM is based on the global model simulations with comprehensive chemistry used for the tropospheric and stratospheric impact analysis. It will allow the emissions, atmospheric chemical concentrations, and radiative forcings to be determined for a user selected market penetration of one of the scenarios examined here (A1FI-FC, A1FI-ICE, B1-FC, B1-ICE). It will output data tables and figures for each of the species of interest $\left(\mathrm{H}_{2}, \mathrm{O}_{3}, \mathrm{CO}, \mathrm{NOx}, \mathrm{OH}\right.$, column $\left.\mathrm{O}_{3}, \mathrm{CO}_{2}\right)$ as latitude $\mathrm{x}$ longitude surface plots, zonal mean altitude x latitude plots, or time series plots. The IAM is based on the distilled science of the sophisticated global chemistry transport models but allows the exploration of $\mathrm{H}_{2}$ adoption scenarios in minutes instead of the weeks to months necessary for the full chemistry model simulations.

- Oxygen plumes from $\mathrm{H}_{2}$ production may increase the risk of fire in close vicinity of the electrolysis facility and should be assessed on a case by case basis. Oxygen $\left(\mathrm{O}_{2}\right)$ is a by-product of the production of hydrogen via water electrolysis. With the large scale production of $\mathrm{H}_{2}$ it is likely that this oxygen will be released to the atmosphere and these increased oxygen concentrations could increase the risk of fire occurrence and spread. The energy demand for the entire U.S. transportation system in 2002 was estimated to be 26.5 Quads. We assume that future road transportation will be roughly equal to this value. The corresponding $\mathrm{O}_{2}$ production is $\sim 5 \times 10^{4} \mathrm{~kg} \mathrm{sec}^{-1}$. Assuming there are 100 $\mathrm{H}_{2}$ factories with equal production capacities distributed throughout the U.S, 
each would release $\sim 500 \mathrm{~kg} \mathrm{O}_{2} \mathrm{sec}^{-1}$. This oxygen is assumed to be released from an $80 \mathrm{~m}$ high stack. A $5 \%$ volume increase in oxygen concentration causes a significant increase in fire spread; therefore we take this as a threshold for a significant impact of oxygen from a large-scale electrolyzer. While this threshold is not exceeded under most conditions, under stagnant atmospheric conditions this threshold could be exceeded for up to $\sim 2 \mathrm{~km}$ downwind of the facility. Though there are many uncertainties and unknowns about the details of the facilities this study points to the necessity of more detailed site and plant specific assessment once the details of future plant design are known.

\section{- Hydrogen embrittlement of materials and structures not likely a threat.}

Analysis of the predicted levels of atmospheric hydrogen combined with an extensive theoretical and experimental analysis of hydrogen embrittlement mechanisms in metals shows that the hydrogen road transportation sector does not represent a threat. The primary concern in a hydrogen economy would be in pressurized storage vessels and pipelines where metals are exposed to high pressures of pure hydrogen for extended times. Knowing this, designs can be adopted and specific metals chosen to reduce or practically eliminate concerns. We therefore conclude that hydrogen embrittlement of metals does not pose a threat to structures or devices under normal circumstances. 


\section{Acknowledgments:}

Funding for this study was provided by the U.S. Department of Energy through award number DE-FC36-07GO17109 to the University of Illinois project 'Evaluation of the Potential Environmental Impacts from Large-Scale Use and Production of Hydrogen in Energy and Transportation Applications'. 


\title{
Section 1 \\ Scenarios for Hydrogen and Other Emissions from Hydrogen-Based Transportation Systems
}

\author{
Wenjing Jia, Seth Olsen, Don Wuebbles, Dong Wang
}

\section{Introduction}

The heavy reliance on fossil fuels in energy and transportation systems have led to a number of environmental issues including impacts on air quality, human health, agriculture, and ecosystems. Hydrogen $\left(\mathrm{H}_{2}\right)$ is being considered as the key fuel for energy and transportation systems of the future because it potentially offers a cleaner and more efficient energy carrier than fossil fuels. The vision for a hydrogen economy is based on the expectations that hydrogen can be produced from domestic energy sources in a manner that is affordable and environmentally benign and that $\mathrm{H}_{2}$ powered vehicle emissions of water and limited amounts of hydrogen would displace fossil fuel combustion byproduct emissions. In order to identify and examine possible near and long-term environmental effects from large-scale use of hydrogen in transportation systems, particularly to evaluate the global atmospheric chemical and climate effects of the switch to a hydrogen economy in the future, we have developed several emissions scenarios for the year 2050 with and without an $\mathrm{H}_{2}$ based transportation sector. These emissions scenarios were prepared for our atmospheric model simulations to evaluate the atmospheric impact of a possible future $\mathrm{H}_{2}$-based transportation sector using the CAM-Chem and MOZART chemistry transport models. Future emissions depend on many highly uncertain factors, for example, population growth, economic growth and technological advances. Given the large uncertainties in these factors (e.g., IPCC SRES 2000) we have chosen to evaluate a range of scenarios encompassing different growth paths and technological options. Two growth paths were selected based on the Intergovernmental Panel on Climate 
Change (IPCC) low emitting (B1) and high emitting (A1FI) scenarios for 2050. These scenarios were chosen because they span the range of the IPCC scenarios.

The base case emissions for the year 2000 use the standard CAM-Chem and MOZART emissions files which are based on the well established POET (Precursors of Ozone and their Effects on the Troposphere) emissions database with some additions. We estimate $\mathrm{H}_{2}$ leakage emissions using a top down approach based on an $\mathrm{H}_{2}$ leakage rate and the amount of $\mathrm{H}_{2}$ needed to meet projected transportation energy requirements.

Here we present our method of calculating the emissions scenarios used in our modeling studies, apply this method to current (year 2000), A1FI 2050, and B1 2050 scenarios and compare the resulting $\mathrm{H}_{2}$ emissions with other published estimates.

\section{Emission Scenarios}

Road transportation systems are likely to make the easiest transition to hydrogen power. We focus on two $\mathrm{H}_{2}$ adoption pathways for each of the IPCC B1 and A1FI growth scenarios: 1) the development and implementation of hydrogen fuel cell engines and 2) the use of hydrogen in internal combustion engines (ICE).

Following the upper-bound market penetration case created by the committee of "The Hydrogen Economy: Opportunities, Costs, Barriers, and R \&D Needs" (The Hydrogen Economy, NRC, 2004), hydrogen vehicles are assumed to capture $100 \%$ of the fuel light-duty vehicles (cars and light trucks) market for new vehicles in 2038, and to reach $100 \%$ fraction of total vehicle miles in 2050, in the United States. The committee focus was on light-duty vehicles, the largest segment of the vehicle market, with the aim of gaining a sense of the potential quantitative significance of a transition to hydrogen. Though hydrogen applications of heavy-duty vehicle, e.g. diesel trucks, are not discussed in this report, it mentions that hydrogen has an optimistic potential for usage in US and Japan over the next few decades and in Europe, although diesel engines will also be used in the next decades. Here we assume all road transportation in the world will switch to hydrogen by year 2050 to examine the maximum potential impact of an $\mathrm{H}_{2}$ based transportation economy. We examine two cases: 1) all future 
road transportation use hydrogen-fueled fuel cells, such that there will be no emissions from fossil fuel combustion byproducts ( $\mathrm{CO}, \mathrm{NOx}, \mathrm{SO}_{2}, \mathrm{VOC}$, Soot, etc.) from land transportation and 2) all future road vehicles use hydrogen-fueled internal combustion engines, such that while there are no associated $\mathrm{CO}, \mathrm{VOC}, \mathrm{SO}_{2}$, or soot emissions, NOx is still emitted from the high temperature ICE combustion process. As a sensitivity study we also evaluate the impact of $\mathrm{H}_{2}$ leakage with no concurrent decrease in other emissions. This scenario, though not realistic, allows us to isolate the impact of hydrogen alone on atmospheric chemistry.

Each of these cases is evaluated for the A1FI fossil fuel intensive scenario which contains higher emissions and the B1 technology/environment intensive scenario which contains lower emissions. In this report and the follow up reports that evaluate the impact of these emissions scenarios the scenarios will be referred to as IPCC_scenario Hydrogen_Society_option, where Hydrogen_Society_option is one of: 1) HSO which refers to the baseline emissions scenario, 2) HS1 which refers to the scenario with additional $\mathrm{H}_{2}$ leakage emissions from an $\mathrm{H}_{2}$-based transportation sector, 3) HS2 which refers to the fuel cell technology option and includes $\mathrm{H}_{2}$ leakage emissions and a corresponding reduction of emissions of all road transportation fossil fuel combustion byproducts, or 4) HS3 which refers to the $\mathrm{H}_{2}$ internal combustion engine option and includes $\mathrm{H}_{2}$ leakage emissions and a corresponding reduction of emissions of all road transportation fossil fuel combustion byproducts except NOx. (Note that in the following reports these scenarios have been renamed as follows: HS0 = Baseline, HS2 $=\mathrm{H}_{2}$-FC, and HS3 $=\mathrm{H}_{2}$-ICE.)

\section{Methods}

\section{Baseline Emissions}

The main global emissions inventory used here for the current (year 2000) atmosphere is POET which is based on version 3 of the Emission Database for Global Atmospheric Research (EDGAR) inventory (Granier et al., 2005, Olivier et al., 2003). Biomass burning emissions are from the Global Fire Emissions Database version 2 (GFED-v2) (Van der Werf GR et al., 2006). The fossil/biofuel $\mathrm{SO}_{2}$ emissions are 
taken from the EDGAR-FT2000 database and volcanic $\mathrm{SO}_{2}$ emissions are from the Global Emissions Inventory Activity (GEIA) (Graedel et al., 1993) database. Soot emissions including its road transportation fraction are from Tami Bond (personal communication). These emission totals are shown in Table 1 broken down by road transportation, all fossil fuel (which includes transportation), other, and total. Since the road transportation $\mathrm{H}_{2}$ component is not contained in the POET database we estimated it using the mass emission ratio of $\mathrm{H}_{2}: \mathrm{CO}(0.03)$ from fossil fuel combustion and CO road transportation emissions $(192.6 \mathrm{Tg} / \mathrm{r})$ from POET. Note that there is a relatively large uncertainty in the $\mathrm{H}_{2}$ : $\mathrm{CO}$ mass emission ratio from fossil fuel use including automobile traffic. Estimates range from 0.01 (Simmonds et al., 2000) to 0.07 (Seiler and Zankl, 1975). Other estimates are 0.025-0.032 (Barnes et al., 2003) and 0.026-0.043 (Vollmer et al., 2007). For this study we have chosen to use a mid-value of 0.03 and assume it remains constant through time.

The future baseline (non $\mathrm{H}_{2}$ road transportation sector) emissions were calculated by scaling these current fossil fuel emissions by growth factors from the IPCC scenarios.

$[$ Future $]=($ Future_scale_factor/Current_scale_factor $) *[$ Current $]$

The brackets [ ] in the above equation indicate an emissions map array for a given specie, e.g., NOx, $\mathrm{CO}, \mathrm{SO}_{2}$ and several NMVOCs: $\mathrm{CH}_{3} \mathrm{COCH}_{3}, \mathrm{C}_{4} \mathrm{H}_{10}, \mathrm{C}_{4} \mathrm{H}_{8}, \mathrm{C}_{10} \mathrm{H}_{16}$, $\mathrm{C}_{2} \mathrm{H}_{4}, \mathrm{C}_{2} \mathrm{H}_{5} \mathrm{OH}, \mathrm{C}_{2} \mathrm{H}_{6}, \mathrm{C}_{3} \mathrm{H}_{6}, \mathrm{C}_{3} \mathrm{H}_{8}, \mathrm{CH}_{2} \mathrm{O}, \mathrm{CH}_{3} \mathrm{CHO}, \mathrm{CH}_{3} \mathrm{OH}$, ISOP, MEK, TOLUENE. For $\mathrm{H}_{2}$ and soot which are not included in the IPCC scenarios, we used the $\mathrm{CO}$ scale factors. All other emissions, e.g., from ocean, biogenic emissions, biomass burning, remain at their current (year 2000) levels. Emissions for these scenarios are shown in Tables 2 and 3 for the A1FI and B1 scenarios respectively, and the region dependent fossil fuel emissions scale factors are shown in Tables 4 and 5. Note that for all of our model simulations CAM-Chem and MOZART used the same emissions species with the exception of $\mathrm{SO}_{2}$ and soot which are not included in MOZART. 


\section{Emissions from an $\mathrm{H}_{2}$ Based Transportation Sector}

For the $\mathrm{H}_{2}$ based transportation sector emissions scenarios we remove the $\mathrm{road} /$ land transportation portion of the emissions from fossil fuel combustion, e.g., $\mathrm{H}_{2}$, $\mathrm{CO}$, VOCs, $\mathrm{NOx}, \mathrm{SO}_{2}$, and soot for the fuel cell technology and $\mathrm{H}_{2}, \mathrm{CO}$, VOCs, $\mathrm{SO}_{2}$, and soot for the ICE technology option, and then add in the $\mathrm{H}_{2}$ emissions due to leakage.

For our assessment we used a leakage rate of $2.5 \%$. However, confidence in the current knowledge of hydrogen leakage rates is low and we are not aware of any real-world measurements of leakage rates. To date, most leakage rate estimates are based on natural gas leakage rates of about $1 \%$ and the assumption that since hydrogen is a smaller more diffusive molecule than methane (the primary component of natural gas) its leakage rate will be higher. Current estimates tend to be in the $1 \%$ to $4 \%$ range (e.g., Schultz et al., 2003, Colella et al., 2005), though much larger rates have been used in some studies (e.g., Tromp et al., 2003). Knowledge of actual leakage rates, their dependence on technological sophistication, and how they will change in the future is one of the key uncertainties in estimating future atmospheric hydrogen emissions.

We assume all road transportation will use hydrogen in the future such that $\mathrm{H}_{2}$-powered vehicles will consume the same amount of energy as would the year 2050 "business-as-usual" fleet assumed in the IPCC SRES A1FI and B1 scenarios (IPCC, $2000 \& 2001)$.

Transportation energy requirements for the current (year 2000), A1FI, and B1 scenarios (Table 6) were calculated with the MiniCAM energy-technology-economics models (e.g., Edmonds et al., 2004a, b). The MiniCAM model considers population, GNP/GDP, energy use, land use, anthropogenic emissions, and other factors and has been used extensively in IPCC evaluations and other reports (e.g., IPCC 2000, CCSP 2007, WMO 2007). The transportation energy requirements were broken down by liquid, gas, electric fuel, and other types. We assumed a 100\% conversion efficiency 
between $\mathrm{H}_{2}$ and liquid and gas fuel types and a $50 \%$ transformation efficiency from $\mathrm{H}_{2}$ to electricity.

The energy density of hydrogen is nearly the same in all fuels (Thomas, 2000). The energy density, also called the energy content of $\mathrm{H}_{2}$, is $39.4 \mathrm{kWh}$ (higher heating value (HHV)) and $33.3 \mathrm{kWh}$ (lower heating value (LHV)), equal to $142 \mathrm{MJ} / \mathrm{kg}$ (HHV) and $120 \mathrm{MJ} / \mathrm{kg}(\mathrm{LHV})$, respectively. This means that every $1 \mathrm{~kg}$ of mass of $\mathrm{H}_{2}$ has an energy value of 142EJ (HHV) and $120 \mathrm{EJ}$ (LHV). Here, we use $120 \mathrm{MJ} / \mathrm{kg}$ (Thomas, 2000) for calculation of $\mathrm{H}_{2}$ demand to achieve an upper limit on the $\mathrm{H}_{2}$ emission flux.

Thus the total $\mathrm{H}_{2}$ demand (Table 6) is given by

$\mathrm{H}_{2}$ Demand $=($ Liquid + Gas + Electric $/ 50 \%) /(120 \mathrm{MJ} / \mathrm{kg})$

where Liquid, Gas, and Electric are the transportation energy requirements in MJ and $50 \%$ is the $\mathrm{H}_{2}$ to electric conversions efficiency. Of this transportation energy demand we assume that $80 \%$ is used for road transportation based on current usage (IPCC 2007). Current fuel cell vehicles are nearly 2.5 times more efficient than gasoline powered ICE vehicles (IPCC 2007) while for diesel powered ICE vehicles this value is much lower. There is much room for improvement in ICE efficiencies with technological advances and materials, and in all IPCC scenarios (e.g., A1FI, A1B, B1, etc.) energy efficiency will increase in year 2050, although to different extents. Therefore we assume that in 2050 fuel cell and ICE vehicles will have comparable efficiencies. It should be noted that while we have assumed that $\mathrm{H}_{2}$ fuel cell and ICE vehicle efficiencies will be equal in 2050 other projections including those from DOE assume that fuel cells will maintain an efficiency advantage over ICE through year 2050, e.g., DOE projections assume an internal combustion engine vehicle efficiency of $40 \%$ and fuel cell vehicle efficiency of $60 \%$ in 2050 . The impact of these different efficiency assumptions, which would decrease our $\mathrm{H}_{2}$ leakage estimates, is discussed in detail below. Assuming a 2.5\% leakage rate the total leakage emissions are shown in Table 6. The total $\mathrm{H}_{2}$ leakage emissions were distributed 
according to the current $\mathrm{CO}_{2}$ road transportation emissions from the EDGAR 32FT2000 (Granier et al., 2005, Olivier et al., 2003) emissions inventory.

\section{Results and Discussion}

In this section we present and examine the $\mathrm{H}_{2} 2050$ emissions scenarios developed using the method detailed above focusing particularly on the changes that result from the adoption of the various $\mathrm{H}_{2}$ usage scenarios. Since there are no published estimates of future emissions changes from the adoption of an $\mathrm{H}_{2}$-based transportation sector, we then apply the method to year 2000 (current) emissions in order to compare with other estimates and evaluate of how this method performs. Note that the calculation of the impact on current emissions is for comparison only and these scenarios are not evaluated in the impact assessment.

\section{Scenario Emissions}

The total speciated emissions for each of the scenarios is then created from the data in Tables 2-3 which describe the baseline HS0 emissions and Table 6 which presents $\mathrm{H}_{2}$ leakage estimates for the A1FI and B1 scenarios (HS1, HS2, and HS3). For example, total emissions for the HS2 fuel cell adoption scenarios are obtained by removing all of the road transportation emissions from the HSO baseline scenario and then adding the $\mathrm{H}_{2}$ leakage emissions while total emissions for the HS3 ICE adoption scenarios are obtained by removing all of the road transportation emissions except NOx from the HSO baseline scenario and then adding the $\mathrm{H}_{2}$ leakage emissions.

The A1FI and B1 scenarios have vastly different total emissions in 2050 due to their somewhat diametrically opposed assumptions about future growth and technology. For every category of emissions the A1FI scenario in 2050 has higher emissions than today while for the B1 scenario in 2050 the emissions of most species are projected to decrease or stay nearly the same as current levels (Figure 1). NOx total emissions in the A1FI HS2 fuel cell adoption scenario are nearly twice as large as in the B1 HS2 fuel cell adoption scenario. 
However there are many common general features in the emissions too. For each specie the emissions distributions in each technology scenario (HSO, HS1, HS2, and HS3) have similar patterns. The geographical distributions of the emissions in the A1FI and B1 scenarios are similar for some species, e.g., $\mathrm{H}_{2}$ and NOx, with larger emissions over more densely populated areas such as the eastern United States, western Europe, and parts of India and Eastern China (e.g., Figures 2 and 3). For some other species, e.g., CO (Figure 4) natural emissions from oceans and soils also contribute leading to different distributions of emissions for these species. In the HS2 fuel cell adoption and HS3 ICE adoption scenarios the emissions decrease for most combustion-related species with the adoption of an $\mathrm{H}_{2}$ powered road transportation sector since the road transportation emissions are removed in an $\mathrm{H}_{2}$ economy. For example, in 2050, CO global emissions decrease by $25 \%$ and $9 \%$ for the A1FI, and B1 both HS2 fuel cell and HS3 ICE adoption scenarios respectively and NOx global emissions decrease by $29 \%$ and $24 \%$ respectively for the HS2 fuel cell adoption scenario (Table 8, Figure 1). Aerosol precursor emissions also decrease; $\mathrm{SO}_{2}$ emissions decrease by $3 \%$ in both the A1FI and B1 scenarios and soot emissions decrease by $17 \%$ for the A1FI scenario and $8 \%$ for the B1 scenario (Table 8 ).

As noted earlier, $\mathrm{H}_{2}$ leakage emissions depend directly on the assumptions about fuel cell and ICE vehicle efficiencies since these efficiencies determine the amount of fuel needed to power the vehicles and hence impact the amount of $\mathrm{H}_{2}$ leaked which is a fixed percentage of the required $\mathrm{H}_{2}$. Assuming equal efficiencies, $\mathrm{H}_{2}$ emissions from road transportation increase about 4 times from $14.8 \mathrm{TgH}_{2} / \mathrm{yr}$ to $60.8 \mathrm{TgH}_{2} / \mathrm{yr}$ for the A1FI scenario and nearly 8 times from $3.2 \mathrm{TgH}_{2} / \mathrm{yr}$ to 24.0 $\mathrm{TgH}_{2} / \mathrm{yr}$ for the B1 scenario (Tables 2-3, 6). Although the relative increase is larger in the B1 scenario the absolute emissions in the B1 scenario are still substantially smaller than in the A1FI scenario. The total $\mathrm{H}_{2}$ emissions increase by nearly $60 \%$ for both the B1 and A1FI scenarios, however the absolute total emissions are nearly twice as large in the A1FI scenario (102.6 $\mathrm{TgH}_{2} / \mathrm{yr}$ ) than the $\mathrm{B} 1$ scenario $\left(53.2 \mathrm{TgH}_{2} / \mathrm{yr}\right.$ ).

If we instead adopt a 1.5 ratio of fuel cell to ICE vehicle efficiency (60\% / $40 \%$ ) the $\mathrm{H}_{2}$ leakage emissions decrease by $33.3 \%$ (1-1.0/1.5) to $40.5 \mathrm{TgH}_{2} / \mathrm{yr}$ and 16 
$\mathrm{TgH}_{2} / \mathrm{yr}$ for the A1FI and B1 scenarios respectively (Table 7). The total $\mathrm{H}_{2}$ emissions decrease by $\sim 20 \%$ for the A1FI scenario and $\sim 15 \%$ for the B1 scenario. On the other hand, if we assume a current fuel cell to ICE efficiency ratio of $~ 2.9$ (Collela et al, 2005) $\mathrm{H}_{2}$ leakage emissions would decrease by nearly $66 \%$.

An interesting question is at what point $\mathrm{H}_{2}$ emissions from fossil fuel powered road transportation would equal those from $\mathrm{H}_{2}$ fuel cell powered road transportation. As discussed earlier $\mathrm{H}_{2}$ emissions from fossil combustion depend on the emission of $\mathrm{H}_{2}$ for a given amount of fuel and the amount of fuel consumed, which depends, of course, on efficiency, while the $\mathrm{H}_{2}$ leakage emissions depend on the leakage rate and amount of hydrogen required which depends directly the ratio of the efficiencies between fossil fuel and fuel cell vehicles and the amount of fuel required. Collela et al (2005) report a break even leakage rate of 3\% for the current vehicle fleet but do not directly note the dependence on vehicle efficiency. Thus for converting the current (year 2000) fleet to fuel cell vehicles (with current efficiencies) the break even leakage rate would be $3.1 \%$ for the A1FI scenario and $3.5 \%$ for the B1 scenario (Table 12). However, for the 2050 scenarios the break even leakage rates are $0.6 \%$ and $0.3 \%$ for the A1FI and B1 scenarios respectively assuming equal efficiencies and $0.9 \%$ and $0.4 \%$ assuming a $60 \%$ to $40 \%$ fuel cell to ICE vehicle efficiency. Note that for each of these the product of the break even leakage rate and the ratio of efficiencies is constant and proportional to the total amount of energy needed for road transportation. While it is interesting to investigate the break even leakage rate for a given scenario, it is important to note its dependence on other factors, e.g., efficiencies, which will change over time. Therefore it is important to realize that the break even leakage percentage will not be constant between different scenarios.

\section{Year $2000 \mathrm{H}_{2}$ emissions from fossil fuel combustion}

Using the method described above we estimate that current global fossil fuel $\mathrm{H}_{2}$ emissions are about $14.4 \mathrm{TgH}_{2} / \mathrm{yr}$. This value is in good agreement with most other estimates (see Table 9 for a comparison of this estimate with other published estimates). Many of these other estimates are based on scaling CO emissions 
estimates by measured $\mathrm{H}_{2} / \mathrm{CO}$ emission ratios (similar to our method) but have used different CO inventories and emission ratios. These estimates generally fall in the 5$25 \mathrm{TgH}_{2} / \mathrm{yr}$ range (Table 9). Some estimates included more processes such as indirect emissions from residential heating, refineries and fertilizer production as fossil fuel related and have slightly higher estimates than ours, e.g., $20 \mathrm{TgH}_{2} / \mathrm{yr}$ (Sanderson et al., 2003), 15-20 $\mathrm{TgH}_{2} / \mathrm{yr}$ (Derwent et al., 2006), and 18.3 $\mathrm{TgH}_{2} / \mathrm{yr}$ (Price et al., 2007). Independent estimates based on isotopic methods give similar values, e.g., Rhee et al.'s (2006) estimate of 9-21 $\mathrm{TgH}_{2} / \mathrm{yr}$. The most recent work based on an exhaustive review of the literature estimates that fossil fuel $\mathrm{H}_{2}$ emissions are in the range of 7-15 $\mathrm{TgH}_{2} / \mathrm{yr}$ (Ehhalt and Rohrer, 2009).

Of the $14.4 \mathrm{TgH}_{2} / \mathrm{yr}$ global fossil fuel $\mathrm{H}_{2}$ emissions we estimate that $6 \mathrm{TgH}_{2} / \mathrm{yr}$ are from road transportation. Though there are fewer estimates of only the road transportation portion of the fossil fuel $\mathrm{H}_{2}$ emissions to compare with, early estimates suggested a wide range of 5-20 $\mathrm{TgH}_{2} / \mathrm{yr}$ (Novelli et al., 1999) while more recent estimates generally fall into the $4-12 \mathrm{TgH}_{2} / \mathrm{yr}$ range (Table 10). The more recent estimates of 5.6 $\mathrm{TgH}_{2} / \mathrm{yr}$ (Jacobsen, 2008) and $6 \mathrm{TgH}_{2} / \mathrm{yr}$ from this work both fall at the low end of the range (6-12 $\left.\mathrm{TgH}_{2} / \mathrm{yr}\right)$ given in Ehhalt and Rohrer's (2009) review paper. Ehhalt and Rohrer (2009) also point out that the slightly higher $\mathrm{H}_{2}: \mathrm{CO}$ emission ratios measured close to the sources are likely to be more representative of the actual emission ratio and that estimates made from measurements further from the source should be regarded as a lower limit. This applies to both of the more recent estimates.

\section{$\mathrm{H}_{2}$ emissions from converting the current road transportation sector to $\mathrm{H}_{2}$ power.}

Based on the B1 and A1FI scenarios for the year 2000 we estimate that $\mathrm{H}_{2}$ emissions from an $\mathrm{H}_{2}$-powered transportation would be $12-14 \mathrm{TgH}_{2} / \mathrm{yr}$ for $\mathrm{H}_{2}$ internal combustion scenarios (Table 6) assuming $\mathrm{H}_{2}$ ICE and gasoline ICE have comparable

efficiencies. For the HS2 fuel cell adoption scenario using current internal combustion engine efficiency ( 0.14 for gasoline, 0.31 for diesel, and 0.5 for fuel cell) and 
assuming that the ratio of gasoline to diesel powered vehicles is $80 \%$ to $20 \%$, the $\mathrm{H}_{2}$ emissions from $\mathrm{H}_{2}$-powered transportation would be 4.5-5.1 $\mathrm{TgH}_{2} / \mathrm{yr}$, which is less than $50 \%$ of the $\mathrm{H}_{2}$ internal combustion scenarios. Though several studies have published $\mathrm{H}_{2}$ emissions estimates for current $\mathrm{H}_{2}$ economies very few have reported the transportation contribution separately (Table 11). In order to compare our estimate with these other estimates we obtain their $\mathrm{H}_{2}$ road transportation emissions by scaling their $\mathrm{H}_{2}$ total fossil fuel emissions (Table 11) using the road transportation energy demand fraction (20\% 25\%) for total fossil fuel energy (IPCC 2007, Evans 2007, Rodrigue et al., 2009) accounting for different $\mathrm{H}_{2}$ leakage rates and different scenario assumptions (Scenario factor) between the other estimates and ours. This method is far from ideal and has large uncertainties but does allow the different estimates to be compared in a somewhat quantitative manner. Thus we estimate other road transportation emissions as $\mathrm{H}_{2}$ road transportation emissions $=\mathrm{H}_{2}$ total fossil fuel emissions * Scenario factor * Our $\mathrm{H}_{2}$ leakage $(2.5 \%) / \mathrm{H}_{2}$ leakage, where the "Scenario factor" is determined from different scenario key assumptions, for example, the fraction of which fossil fuels were converted to $\mathrm{H}_{2}$ usage and the energy demand fraction used in road transportation.

Using this method we estimate that of the $60-120 \mathrm{TgH}_{2} / \mathrm{yr}$ total $\mathrm{H}_{2}$ fossil fuel emissions suggested by Tromp et al. (2003) from replacing all oil and gasoline combustion by hydrogen fuel cells with $10 \sim 20 \% \mathrm{H}_{2}$ leakage that at least $11.5 \mathrm{TgH}_{2} / \mathrm{yr}$ would be due to road transportation (with a scenario factor of $0.48 / 0.50 * 0.8$ since more than $48 \%$ of world gasoline or oil is used in road transportation today and gasoline accounts for $50 \%$ of total transportation energy use, and about $80 \%$ of total transport energy from road traffic (IPCC 2007)). We estimate transportation emissions of about 1.1 10.4 $\mathrm{TgH}_{2} / \mathrm{yr}$ for the Schultz et al.(2003) scenario assuming a $0.20 \sim 0.25$ scenario factor since $20 \% \sim 25 \%$ of total fossil fuel energy used in transportation today (IPCC 2007, Evans 2007, Rodrigue et al., 2009). For Warwick et al. (2004) we estimate that $13 \sim 16.3 \mathrm{TgH}_{2} / \mathrm{yr}$ of the total fossil $26-312 \mathrm{TgH}_{2} / \mathrm{yr}$ are due to transportation with same scenario factor $(0.20 \sim 0.25$ for energy demand ratio of fossil fuel in transportation today). Similarly we estimate that $12.5 \sim 15.6 \mathrm{TgH}_{2} / \mathrm{yr}$ of 
the total $25 \mathrm{TgH}_{2} / \mathrm{yr}$ fossil emissions of Derwent et al. (2006) are due to transportation, also using the same scenario factor $(0.20 \sim 0.25)$. Thus our estimate of 12 to $14 \mathrm{TgH}_{2} / \mathrm{yr}$ for the $\mathrm{H}_{2}$ internal combustion scenario appears to agree with these other estimates. In addition we estimate that the $4.8 \mathrm{TgH}_{2} / \mathrm{yr} \mathrm{H}_{2}$ road transportation emissions for a fuel cell powered fleet from Jacobsen (2008) would be $\sim 4 \mathrm{TgH}_{2} / \mathrm{yr}$ when adjusted our $2.5 \%$ leakage rate. Thus our estimate of $4.5-5.1 \mathrm{TgH}_{2} / \mathrm{yr} \mathrm{H}_{2}$ emissions for the current fuel cell scenario is in fairly good agreement with the 4 $\mathrm{TgH}_{2} / \mathrm{yr}$ estimate of Jacobsen (2008).

\section{$\mathrm{CO}_{2}$ emissions}

In addition to reductions in other fossil fuel combustion related byproducts with the adoption on of an $\mathrm{H}_{2}$ based transportation sector, there will also be large decreases in $\mathrm{CO}_{2}$ emissions. Based on the energy demand for road transportation from different fossil fuel types (liquid, gas, electricity) (Table 6), and the lower heating value energy density for each fossil fuel type (liquid oil: $43 \mathrm{MJ} / \mathrm{kg}$, gas: $38 \mathrm{MJ} / \mathrm{kg}$, electricity (assuming coal generation): $24 \mathrm{MJ} / \mathrm{kg}$ ), as well as the $\mathrm{CO}_{2}$ yield from each fuel type (46/14 for liquid, 46/16 for gas, and 46/12 for electricity), we obtain $\mathrm{CO}_{2}$ emissions from fossil fuel based transportation sector (Table 13). $\mathrm{CO}_{2}$ emissions from fossil fuel based road transportation are $22.1 \mathrm{GtCO}_{2} / \mathrm{yr}$ for $2050 \mathrm{~A} 1 \mathrm{FI}$ and 10.1 $\mathrm{GtCO}_{2} / \mathrm{yr}$ for $2050 \mathrm{~B} 1$ scenario. Since we have assumed that $\mathrm{H}_{2}$ is produced and distributed using non carbon emitting power sources there are no $\mathrm{CO}_{2}$ emissions associated with hydrogen powered road transportation for both the 2050 A1FI and B1 scenarios. Total 2050 fossil $\mathrm{CO}_{2}$ emissions decrease by $26.1 \%$ for the A1FI scenario and $23.5 \%$ for the B1 scenario upon switching to hydrogen powered road transportation.

\section{Conclusions and Implications}

We have developed a series of emissions scenarios to be used in model simulation to evaluate the environmental impact of transforming to an $\mathrm{H}_{2}$ based road transportation sector in year 2050. Due to the large uncertainties inherent in predicting 
growth and technology changes over time we have chosen scenarios based on IPCC scenarios that span the range of generally accepted possibilities. While $\mathrm{H}_{2}$ emissions could increase substantially with the adoption of an $\mathrm{H}_{2}$ based transportation sector in these scenarios, the emissions of key ozone and aerosol precursors would decrease: NOx by $24 \%$ and $28 \%$, CO by $9 \%$ and $25 \%$, NMVOCs by $8 \%$ and $14 \%$, and soot by $8 \%$ and $17 \%$ for the B1 and A1FI HS2 fuel cell adoption scenarios. By year $2050 \mathrm{CO}_{2}$ total fossil emissions would decrease by more than $20 \%$ in both A1FI and B1 hydrogen powered transportation societies (HS2 fuel cell and HS3 ICE adoption scenarios).

There are relatively large uncertainties in the $\mathrm{H}_{2}$ emissions. These uncertainties are due uncertainties in parameters and knowledge of how these parameters will change over time, e.g., $\mathrm{H}_{2}: \mathrm{CO}$ emissions ratios, vehicle efficiency, and leakage rates. Uncertainty in growth paths is also a major factor as is evident from the differences between the B1 and A1FI based scenario emissions. In general, for this study we have chosen parameters that should provide a reasonable upper bound to the $\mathrm{H}_{2}$ emissions. The choice towards the upper bound of the uncertainties was deliberate since increased atmospheric $\mathrm{H}_{2}$ concentrations may have an adverse impact on stratospheric ozone. If fuel cell vehicles maintain their efficiency advantage into the future these emissions estimates would decrease proportionally to the ratio of efficiencies. There are also uncertainties in the magnitude of the changes in the other non- $\mathrm{H}_{2}$ emissions. However for all expected possible scenarios emissions of these species decrease (or at worst remain unchanged as for NOx in the HS3 ICE adoption scenario) which would tend to improve air quality metrics. These uncertainties, though real, are likely not as key to policy considerations since possible adverse impacts are more problematic than knowing precisely how much improvement will occur provided one is confident that improvement will occur.

\section{References}


Barnes, D. H., S. C. Wofsy, B. P. Fehlau and E. W. Gottlieb. (2003), Hydrogen in the atmosphere: observations above a forest canopy in a polluted environment, J. Geophys. Res., Vol.108, No. D6, 4197,doi:10.1029/2001JD001199.

CCSP (2007), Scenarios of Greenhouse Gas Emissions and Atmospheric Concentrations. U.S. CCSP Synthesis and Assessment Product 2.1a.

CCSP (2007), Global-Change Scenarios: Their Development and Use. U.S. CCSP Synthesis and Assessment Product 2.1b.

Colella, W. G., M. Z. Jacobson, and D. M. Golden (2005), Switching to a US hydrogen fuel cell vehicle fleet: The resultant change in emissions, energy use and GHGs, J. Power Sources, 150, 150-181.

Derwent, R., P. Simmonds and S. O'Doherty, A. Manning and W. Collins, D. Stevenson (2006), Global environmental impacts of the hydrogen economy. Int. J. Nuclear Hydrogen Production and Applications, 1, 1, 57-67.

Edmonds, J., J. Clarke, J. Dooley, S. H. Kim, S. J. Smith (2004a), Stabilization of CO2 in a B2 World: Insights on The Roles of Carbon Capture and Disposal, Hydrogen, and Transportation Technologies. Energy Economics, 26, 517-537.

Edmonds, J. A., J. Clarke, J. Dooley, S. H. Kim, and S. J. Smith (2004b), Modeling greenhouse gas energy technology responses to climate change. Energy, 29, 1529-1536.

Ehhalt, D.H. and F. Rohrer (2009), The tropospheric cycle of H2: a critical review, Tellus, 61B, 500-535.

Evans, R.L. (2007), Fueling our future: an introduction to sustainable energy, Cambridge University Press, Cambridge, UK.

Graedel, T. F., T. S. Bates, A. F. Bouman, D. Cunnold, J. Dignon, I. Fung, D. J. Jacob, B. K. Lamb, J. A. Logan, G. Marland, P. Middleton, J. M. Pacyna, M. Placet, and C. Veldt (1993) A compilation of inventories of emissions to the atmosphere. Global Biogeochem. Cycles, 7: 1-26.

Granier, C., J. F. Lamarque, A. Mieville, J. F. Muller, J. Olivier, J. Orlando, J. Peters, G. Petron, G. Tyndall, S. Wallens (2005), POET, a database of surface emissions of ozone precursors, http://www.aero.jussieu.fr/projet/ACCENT/POET.php.

Hauglustaine, D.A., and D.H. Ehhalt(2002) A three-dimensional model of molecular hydrogen in the troposphere, J. GEOPHYS. RES., Vol.107, No.D17, 4330. 
IPCC (2001), Climate Change 2001, The Scientific Basis. Contribution of Working Group 1 to the Third Assessment Report of the IPCC, Cambridge University Press, Cambridge, UK and New York, USA.

IPCC (2007), Climate change 2007:Mitigation of Climate Change. Contribution of Working Group III to the Fourth Assessment Report of the IPCC, Cambridge University Press, Cambridge, UK and UY, USA.

Jacobson, M. Z., W. G. Colella, and D. M. Golden (2005), Cleaning the air and improving health with hydrogen fuel-cell vehicles. Science, 308, 1901-1905.

Jacobson, M.Z. (2008), Effects of wind-powered hydrogen fuel cell vehicles on stratospheric ozone and global climate, Geophys. Res. Let., Vol.35, L19803.

Nakicenovic, N., et al. (2000), IPCC Special Report on Emissions Scenarios (SRES), Special Report on Emissions Scenarios. Working Group III, IPCC, Cambridge University Press, Cambridge, 2000.

Novelli, P. C., P. M. Lang, K. A. Masarie, D. F. Hurst, R. Myers(1999). Molecular hydrogen in the troposphere: global distribution and budget. J. Geophys. Res. 104, 30 427-30 444.

Olivier J., J. Peters, C. Granier, G. Petron, J.F. Muller, and S. Wallens (2003): Present and future surface emissions of atmospheric compounds, POET report \#2, EU project EVK2-1999-00011.

Olivier, J.G.J., J.A.Van Aardenne, F. Dentener, L. Ganzeveld, and J.A.H.W. Peters (2005). "Recent trends in global greenhouse gas emissions: regional trends and spatial distribution of key sources", in Non-CO2 Greenhouse Gases (NCGG-4), A. van Amstel (coord.), page 325-330. Millpress, Rotterdam, ISBN 9059660439.

Price, H., L., Jaegle, A. Rice, P. Quay, P. C. Novelli(2007), Global budget ofmolecular hydrogen and its deuterium content: constraints from ground station, cruise, and aircraft observations. J.Geophys Res. 112, D22108, doi:10.1029/2006JD008152.

Rhee, T. S., C. A. M. Brenninkmeijer, and T. R“ockmann (2006). The overwhelming role of soils in the global atmospheric hydrogen cycle. Atmos. Chem. Phys. 6, 16111625 .

Rodrigue Jean-Paul, Claude Comtois, Brian Slack (2009), The Geography of Transport Systems, ISBN: 978-0-415-48324-7, Routledge. 
Sanderson, M. G., W. J. Collins, R. G. Derwent, and C. E. Johnson(2003). Simulation of global hydrogen levels using a Lagrangian threedimensional model. J. Atmos.

Chem. 46, 15-28.

Schultz, M., T. Diehl, G. Brasseur, and W. Zittel (2003), Air pollution and climateforcing 2000.impacts of a global hydrogen economy. Science, 302, 624-627.

Seiler, W. and Zank, H. (1975), Die Spurengase CO und H2 uber Munchen. Umschau 75(23), 735-736.

Simmonds, P.G., R.G. Derwent, S. O’Doherty, D.B. Ryall, L.P. Steele, R.L. Langenfelds, P. Salameh, H.J. Wang, C.H. Dimmer, L.E. Hudson(2000), Continuous high-frequency observations of hydrogen at the Mace Head baseline atmospheric monitoring station over the 1994-1998 period. J. Geophys. Res., 105(D10), 1210512121.

Steinbacher, M., A. Fischer, M. K. Vollmer, B. Buchmann, S. Reimann (2007), Perennial observations of molecular hydrogen (H2) at a suburban site in Switzerland. Atmos. Env. 41, 2111-2124.

Thomas George (2000): Overview of Storage Development DOE Hydrogen Program , Hydrogen Program Review, San Ramon, CA.

Tromp, T., R. Shia, M. Allen, J. Eiler, and Y. Yung (2003), Potential environmental impact of a hydrogen economy on the stratosphere. Science 300, 1740-1742.

Van der Werf, G.R., J. T. Randerson, L. Giglio, G. J. Collatz, P. S. Kasibhatla, A. F. Arellano(2006), Interannual variability in global biomass burning emissions from 1997 to 2004, Atmos. Chem. Phys. 6: 3423-3441 AUG 21.

Vollmer, M.K., N. Juergens, M. Steinbacher, S. Reimann, M. Weilenmann, B. Buchmann (2007), Road vehichle emissions of molecular hydrogen (H2) from a tunnel study. Atmos Environ, 41:8355-69.

Warwick, N. J., S. Bekki, E. G. Nisbet, and J. A. Pyle (2004), Impact of a hydrogen economy on the stratosphere and troposphere studied in a 2-D model. Geophys. Res. Lett., 31, doi:10.1029/2003GL019224.

World Meteorological Organization (WMO) (2007), Scientific Assessment of Stratospheric ozone: 2006. WMO Global Ozone Research and Monitoring Project - Report No. 50, Geneva, Switzerland.

Xiao, X., R. G. Prinn, P. G. Simmonds, L. P. Steele, P. C. Novelli(2007), Optimal estimation of the soil uptake of molecular hydrogen from the Advanced Global 
Atmospheric Gases Experiments and other measurements. J. Geophys. Res. 112, D07303, doi:10.1029/2006JD007241. 
Table 1. Year 2000 emissions for different species based on the POET emissions database with additions as described in the text. Note that total fossil emissions include road transportation emissions. Units are $\mathrm{Tg} / \mathrm{yr}$ except as noted.

\begin{tabular}{|l|c|c|c|c|}
\hline Specie & $\begin{array}{c}\text { Road } \\
\text { Transportation }\end{array}$ & Total Fossil & Other & Total \\
\hline $\mathrm{H}_{2}$ & 6 & 14.4 & 24.6 & 40 \\
\hline $\mathrm{CO}$ & 204 & 332 & 1030 & 1361 \\
\hline $\mathrm{NOx}[\mathrm{TgN} / \mathrm{yr}]$ & 10.2 & 27 & 16.8 & 43.8 \\
\hline $\mathrm{SO}_{2}[\mathrm{TgS} / \mathrm{yr}]$ & 2.5 & 68.4 & 7.2 & 75.6 \\
\hline Black Carbon (Soot) & 1.17 & 2.99 & 5.26 & 8.26 \\
\hline Total NMVOCs & 45.0 & 116.4 & 353.2 & 469.6 \\
\hline $\mathrm{C}_{2} \mathrm{H}_{4}$ & 1.07 & 1.71 & 19.09 & 20.8 \\
\hline $\mathrm{C}_{2} \mathrm{H}_{6}$ & 0.17 & 5.28 & 9.22 & 14.5 \\
\hline $\mathrm{C}_{3} \mathrm{H}_{6}$ & 0.47 & 0.86 & 5.77 & 6.63 \\
\hline $\mathrm{C}_{3} \mathrm{H}_{8}$ & 0.35 & 6.99 & 3.41 & 10.4 \\
\hline $\mathrm{C}_{4} \mathrm{H}_{10}$ & 23.1 & 62.7 & 2.4 & 65.1 \\
\hline $\mathrm{C}_{4} \mathrm{H}_{8}$ & 3.93 & 5.2 & 5.2 & 10.4 \\
\hline $\mathrm{CH}_{2} \mathrm{O}$ & 0.35 & 0.69 & 6.31 & 7 \\
\hline $\mathrm{CH}_{3} \mathrm{CHO}$ & 0.71 & 1.38 & 10.62 & 12 \\
\hline $\mathrm{CH}_{3} \mathrm{OH}$ & 0 & 0.96 & 241.8 & 242.8 \\
\hline $\mathrm{C}_{2} \mathrm{H}_{5} \mathrm{OH}$ & 0 & 2.32 & 3.65 & 5.97 \\
\hline $\mathrm{CH}_{3} \mathrm{COCH}$ & 0.47 & 28.43 & 28.9 \\
\hline $\mathrm{MEK}^{\mathrm{Toluene}}$ & 0.01 & 1.32 & 8.49 & 9.81 \\
\hline & 0.01 & 26.5 & 8.8 & 35.3 \\
\hline
\end{tabular}

Table 2. $\mathrm{H}_{2}$ and other related emissions for the 2050 A1FI HS0 baseline scenario. Note that total fossil emissions include road transportation emissions. Units are $\mathrm{Tg} / \mathrm{yr}$ except as noted.

\begin{tabular}{|l|c|c|c|c|}
\hline \multicolumn{1}{|c|}{ Specie } & $\begin{array}{c}\text { Road } \\
\text { Transportation }\end{array}$ & Total Fossil & Other & Total \\
\hline $\mathrm{H}_{2}$ & 14.8 & 32 & 24.6 & 56.6 \\
\hline $\mathrm{CO}$ & 461.3 & 815.1 & 1029.6 & 1844.7 \\
\hline $\mathrm{NOx}[\mathrm{TgN} / \mathrm{yr}]$ & 27.1 & 77.6 & 16.7 & 94.3 \\
\hline $\mathrm{SO}_{2}[\mathrm{TgS} / \mathrm{yr}]$ & 2.9 & 76.3 & 7.2 & 83.5 \\
\hline Black Carbon (Soot) & 2.28 & 8.48 & 5.26 & 13.7 \\
\hline Total NMVOCs & 82.4 & 247.6 & 353.3 & 600.9 \\
\hline $\mathrm{C}_{2} \mathrm{H}_{4}$ & 1.85 & 3.42 & 19.1 & 22.5 \\
\hline $\mathrm{C}_{2} \mathrm{H}_{6}$ & 0.3 & 13.2 & 9.2 & 22.4 \\
\hline $\mathrm{C}_{3} \mathrm{H}_{6}$ & 0.79 & 1.74 & 5.77 & 7.51 \\
\hline $\mathrm{C}_{3} \mathrm{H}_{8}$ & 0.7 & 16.7 & 3.4 & 20.1 \\
\hline $\mathrm{C}_{4} \mathrm{H}_{10}$ & 40.8 & 133 & 2.4 & 135.4 \\
\hline $\mathrm{C}_{4} \mathrm{H}_{8}$ & 7.18 & 10.5 & 5.19 & 15.7 \\
\hline
\end{tabular}




\begin{tabular}{|l|c|c|c|c|}
\hline $\mathrm{CH}_{2} \mathrm{O}$ & 0.62 & 1.45 & 6.32 & 7.77 \\
\hline $\mathrm{CH}_{3} \mathrm{CHO}$ & 1.4 & 2.97 & 10.6 & 13.6 \\
\hline $\mathrm{CH}_{3} \mathrm{OH}$ & 0 & 2.18 & 241.8 & 244 \\
\hline $\mathrm{C}_{2} \mathrm{H}_{5} \mathrm{OH}$ & 0 & 5.07 & 3.65 & 8.72 \\
\hline $\mathrm{CH}_{3} \mathrm{COCH}$ & 0.04 & 1.02 & 28.5 & 29.5 \\
\hline $\mathrm{MEK}$ & 0.02 & 2.53 & 8.49 & 11.02 \\
\hline Toluene & 28.7 & 53.8 & 8.8 & 62.7 \\
\hline
\end{tabular}

Table 3. $\mathrm{H}_{2}$ and other related emissions for the $2050 \mathrm{~B} 1 \mathrm{HS} 0$ baseline scenario. Note that total fossil emissions include road transportation emissions. Units are $\mathrm{Tg} / \mathrm{yr}$ except as noted.

\begin{tabular}{|l|c|c|c|c|}
\hline Specie & $\begin{array}{c}\text { Road } \\
\text { Transportation }\end{array}$ & Total Fossil & Other & Total \\
\hline $\mathrm{H}_{2}$ & 3.2 & 7.8 & 24.6 & 32.4 \\
\hline $\mathrm{CO}$ & 116.2 & 193.6 & 1029.7 & 1223.3 \\
\hline NOx [TgN/yr] & 11.2 & 29.3 & 16.7 & 46 \\
\hline $\mathrm{SO}_{2}[\mathrm{TgS} / \mathrm{yr}]$ & 2.4 & 63.3 & 7.1 & 70.4 \\
\hline Black Carbon (Soot) & 0.56 & 1.97 & 5.26 & 7.23 \\
\hline Total NMVOCs & 34.2 & 89.4 & 353.3 & 442.7 \\
\hline $\mathrm{C}_{2} \mathrm{H}_{4}$ & 0.8 & 1.29 & 19.11 & 20.4 \\
\hline $\mathrm{C}_{2} \mathrm{H}_{6}$ & 0.1 & 4.12 & 9.18 & 13.3 \\
\hline $\mathrm{C}_{3} \mathrm{H}_{6}$ & 0.35 & 0.65 & 5.77 & 6.42 \\
\hline $\mathrm{C}_{3} \mathrm{H}_{8}$ & 0.27 & 5.7 & 3.41 & 9.11 \\
\hline $\mathrm{C}_{4} \mathrm{H}_{10}$ & 17.3 & 48.6 & 2.4 & 51 \\
\hline $\mathrm{C}_{4} \mathrm{H}_{8}$ & 2.98 & 3.91 & 5.21 & 9.12 \\
\hline $\mathrm{CH}_{2} \mathrm{O}$ & 0.26 & 0.53 & 6.32 & 6.85 \\
\hline $\mathrm{CH}_{3} \mathrm{CHO}$ & 0.6 & 1.06 & 10.64 & 11.7 \\
\hline $\mathrm{CH}_{3} \mathrm{OH}$ & 0 & 0.77 & 241.8 & 242.6 \\
\hline $\mathrm{C}_{2} \mathrm{H}_{5} \mathrm{OH}$ & 0 & 1.72 & 3.65 & 5.37 \\
\hline $\mathrm{CH}_{3} \mathrm{COCH}$ & 0.004 & 0.36 & 28.45 & 28.8 \\
\hline $\mathrm{MEK}^{\mathrm{Toluene}_{3}}$ & 0.006 & 0.95 & 8.49 & 9.44 \\
\hline & 11.5 & 19.8 & 8.8 & 28.6 \\
\hline
\end{tabular}

Table 4. Fossil fuel emissions scale factors for IPCC A1FI both world and regions. (OECD90: Organization for Economic Cooperation and Development member states as at 1990; ASIA: Asia excluding the Middle East; ALM: Africa, Latin America and Middle East; REF: Central and Eastern Europe and Newly Independent States of the former Soviet Union.)

\begin{tabular}{|l|l|l|c|c|c|}
\hline World - A1FI & Specie & Unit & 2000 & 2050 & $2050 / 2000$ \\
\hline & SOx & MtS & 69.0 & 80.5 & 1.17 \\
\hline & NOx & MtN & 32 & 95 & 2.97 \\
\hline & CO & MtCO & 877 & 2159 & 2.46 \\
\hline
\end{tabular}




\begin{tabular}{|l|l|l|c|c|c|}
\hline & NMVOC & Mt & 141 & 322 & 2.28 \\
\hline OECD90 & & & & & \\
\hline & SOx & MtS & 17.0 & 5.1 & 0.30 \\
\hline & NOx & MtN & 12 & 16 & 1.30 \\
\hline & CO & MtCO & 161 & 250 & 1.55 \\
\hline & NMVOC & Mt & 36 & 37 & 1.02 \\
\hline ASIA & & & & & \\
\hline & SOx & MtS & 25.3 & 37.0 & 1.46 \\
\hline & NOx & MtN & 9 & 44 & 4.94 \\
\hline & CO & MtCO & 270 & 1030 & 3.82 \\
\hline & NMVOC & Mt & 37 & 119 & 3.18 \\
\hline ALM & & & & & \\
\hline & SOx & MtS & 12.8 & 24.7 & 1.94 \\
\hline & NOx & MtN & 8 & 25 & 3.20 \\
\hline & CO & MtCO & 404 & 714 & 1.77 \\
\hline & NMVOC & Mt & 55 & 110 & 2.00 \\
\hline REF & & & & & \\
\hline & SOx & MtS & 11.0 & 10.7 & 0.97 \\
\hline & NOx & MtN & 3 & 9 & 3.20 \\
\hline & CO & MtCO & 41 & 166 & 4.01 \\
\hline & NMVOC & Mt & 13 & 57 & 4.38 \\
\hline
\end{tabular}

Table 5. Fossil fuel emissions scale factors for IPCC B1 both world and regions. (OECD90: Organization for Economic Cooperation and Development member states as at 1990; ASIA: Asia excluding the Middle East; ALM: Africa, Latin America and Middle East; REF: Central and Eastern Europe and Newly Independent States of the former Soviet Union.)

\begin{tabular}{|l|l|l|c|c|c|}
\hline World - B1 & Specie & Unit & 2000 & 2050 & $2050 / 2000$ \\
\hline & SOx & MtS & 69.0 & 68.9 & 0.998 \\
\hline & NOx & MtN & 32 & 39 & 1.21 \\
\hline & CO & MtCO & 877 & 471 & 0.54 \\
\hline & NMVOC & Mt & 141 & 116 & 0.82 \\
\hline OECD90 & & & & & \\
\hline & SOx & MtS & 17.0 & 2.5 & 0.14 \\
\hline & NOx & MtN & 12 & 5 & 0.39 \\
\hline & CO & MtCO & 161 & 85 & 0.53 \\
\hline & NMVOC & Mt & 36 & 21 & 0.58 \\
\hline ASIA & & & & & \\
\hline & SOx & MtS & 25.3 & 21.4 & 0.85 \\
\hline & NOx & MtN & 9 & 13 & 1.48 \\
\hline & CO & MtCO & 270 & 245 & 0.91 \\
\hline ALM & NMVOC & Mt & 37 & 37 & 1.00 \\
\hline & & & & & \\
\hline & SOx & MtS & 12.8 & 35.6 & 2.79 \\
\hline & NOx & MtN & 8 & 18 & 2.28 \\
\hline & CO & MtCO & 404 & 121 & 0.30 \\
\hline REF & NMVOC & Mt & 55 & 47 & 0.86 \\
\hline & & & & & \\
\hline & & & & & \\
\hline & & & & &
\end{tabular}




\begin{tabular}{|l|l|l|c|c|c|}
\hline & SOx & MtS & 11.0 & 6.5 & 0.59 \\
\hline & NOx & MtN & 3 & 3 & 0.90 \\
\hline & CO & MtCO & 41 & 19 & 0.47 \\
\hline & NMVOC & Mt & 13 & 11 & 0.85 \\
\hline
\end{tabular}

Table 6. Energy demand, hydrogen demand, and hydrogen leakage emissions for the transportation sector for the A1FI and B1 scenarios assuming $120 \mathrm{MJ} / \mathrm{kgH}_{2}$, a $2.5 \%$ leakage rate, and that road transportation accounts for $80 \%$ of the total.

\begin{tabular}{|c|c|c|c|}
\hline \multirow{6}{*}{ A1FI } & Transportation Fuel Type & 2000 & 2050 \\
\hline & \begin{tabular}{|l|} 
Liquid \\
\end{tabular} & $64.4 \mathrm{EJ}$ & $266.0 \mathrm{EJ}$ \\
\hline & Gas & $1.0 \mathrm{EJ}$ & $5.8 \mathrm{EJ}$ \\
\hline & Electric & $0.6 \mathrm{EJ}$ & $8.3 \mathrm{EJ}$ \\
\hline & $\mathrm{H}_{2}$ Demand & $0.556 \mathrm{Pg}$ & $2.403 \mathrm{Pg}$ \\
\hline & $\mathrm{H}_{2}$ Leakage & $14 \mathrm{Tg}$ & $60.8 \mathrm{Tg}$ \\
\hline \multirow{6}{*}{ B1 } & Transportation Fuel Type & 2000 & 2050 \\
\hline & \begin{tabular}{|c|} 
Liquid \\
\end{tabular} & $56.2 \mathrm{EJ}$ & $123.0 \mathrm{EJ}$ \\
\hline & Gas & $1.0 \mathrm{EJ}$ & $2.4 \mathrm{EJ}$ \\
\hline & Electric & $0.6 \mathrm{EJ}$ & $3.4 \mathrm{EJ}$ \\
\hline & $\mathrm{H}_{2}$ Demand & $0.486 \mathrm{Pg}$ & $1.101 \mathrm{Pg}$ \\
\hline & $\mathrm{H}_{2}$ Leakage & $12 \mathrm{Tg}$ & $24 \mathrm{Tg}$ \\
\hline
\end{tabular}

Table 7. Comparison of $\mathrm{H}_{2}$ emissions for different sectors for 2050 HS2 scenarios assuming equal vehicle efficiencies and $40 \%$ internal combustion engine and $60 \%$ fuel cell vehicle efficiencies (Unit: $\mathrm{TgH}_{2} / \mathrm{yr}$ ).

\begin{tabular}{|c|c|c|c|}
\hline A1FI & $\begin{array}{c}\text { Equal } \\
\text { Efficiencies }\end{array}$ & $\begin{array}{c}40 \% \text { / 60\% } \\
\text { Efficiencies }\end{array}$ & $\begin{array}{c}\text { Change } \\
{[\%]}\end{array}$ \\
\hline Transportation Emissions & 60.8 & 40.5 & -33.3 \\
\hline Other Fossil Emissions & 17.2 & 17.2 & 0 \\
\hline Total Fossil Emissions & 78 & 57.7 & -26.0 \\
\hline Other Emissions & 24.6 & 24.6 & 0 \\
\hline Total Emissions & 1026 1 & $40 \% 2,70 \%$ & Change \\
\hline B1 & Efficiencies & Efficiencies & {$[\%]$} \\
\hline Transportation Emissions & 24 & 16 & -33.3 \\
\hline Other Fossil Emissions & 4.6 & 4.6 & 0 \\
\hline Total Fossil Emissions & 28.6 & 20.6 & -28 \\
\hline Other Emissions & 24.6 & 24.6 & 0 \\
\hline Total Emissions & 53.2 & 45.2 & -15 \\
\hline
\end{tabular}


Table 8. Total emissions changes upon adoption of an $\mathrm{H}_{2}$-based transportation sector for the 2050 A1FI HS2 and B1 HS2 scenarios (Note that brackets contain results assuming $40 \%$ ICE efficiency and $60 \%$ fuel cell efficiency).

\begin{tabular}{|l|c|c|}
\hline & \multicolumn{2}{|c|}{ Change in emissions [\%] } \\
\hline Specie & A1FI & $\mathrm{B} 1$ \\
\hline $\mathrm{H}_{2}$ & $+81.3(+45.4)$ & $+64.2(+39.5)$ \\
\hline $\mathrm{NOx}$ & -28.7 & -24.4 \\
\hline $\mathrm{CO}$ & -25.0 & -9.5 \\
\hline $\mathrm{NMVOCs}$ & -13.7 & -7.7 \\
\hline $\mathrm{SO}$ & -3.4 & -3.4 \\
\hline Soot & -16.6 & -7.7 \\
\hline
\end{tabular}

Table 9. Estimates of current $\mathrm{H}_{2}$ emissions from fossil fuel combustion.

\begin{tabular}{|l|c|}
\hline & $\mathrm{TgH}_{2} / \mathrm{yr}$ \\
\hline This work & 14.4 \\
\hline Novelli et al. (1999) & $5-25$ \\
\hline Hauglustaine et al. (2002) & 16 \\
\hline Tromp et al. (2003) & $5-25$ \\
\hline Schultz et al. (2003) & $5-25$ \\
\hline Sanderson et al. (2003) & 20.0 \\
\hline Derwent et al. (2006) & $15-20$ \\
\hline Rhee et al. (2006) & $9-21$ \\
\hline Vollmer et al. (2007) & 15 \\
\hline Price et al. (2007) & 18.3 \\
\hline Xiao et al. (2007) & $5-25$ \\
\hline Ehhalt et al. (2009) & $7-15$ \\
\hline $\begin{array}{l}\text { D.Streets, (from } \\
\text { Jacobson's DOE Merit } \\
\text { Review 2009) }\end{array}$ & 8.4 \\
\hline
\end{tabular}

Table 10. Estimates of current $\mathrm{H}_{2}$ emissions from road transportation.

\begin{tabular}{|l|c|}
\hline & $\mathrm{TgH}_{2} / \mathrm{yr}$ \\
\hline This work & 6 \\
\hline Novelli et al. (1999) & $5-20$ \\
\hline Vollmer et al.(2007) & $4.2-8.1$ \\
\hline Jacobson (2008) & 5.58 \\
\hline Ehhalt et al. (2009) & $6-12$ \\
\hline
\end{tabular}


Table 11. Estimates of $\mathrm{H}_{2}$ leakage emissions in a current $\mathrm{H}_{2}$-economy.

\begin{tabular}{|c|c|c|c|}
\hline & $\begin{array}{l}\text { Total } \mathrm{H}_{2} \\
\text { Fossil } \\
\text { Emissions } \\
(\mathrm{TgH} / \mathrm{yr}) \\
\end{array}$ & Key Assumptions & $\mathrm{H}_{2}$ Leakage \\
\hline This work & $15.8 \sim 17.8$ & $\begin{array}{l}\text { Current (year 2000) total world road } \\
\text { transportation switches to } \mathrm{H}_{2} \text { economy }\end{array}$ & $2.5 \%$ \\
\hline Tromp et al. (2003) & $60-120$ & $\begin{array}{l}\text { Hydrogen fuel cells replace all oil or gasoline } \\
\text { combustion; Assuming surface } \mathrm{H}_{2} \text { mixing ratio } \\
\text { quadrupled }\end{array}$ & $10-20 \%$ \\
\hline Schultz et al. (2003) & $6.8-50$ & If $100 \%$ fossil fuels conversion to $\mathrm{H}_{2}$ technology & $\begin{array}{c}3 \%(0-3 \% \text { plus } \\
\text { test at } 10 \%)\end{array}$ \\
\hline Warwick et al. (2004) & 26-312 & $\begin{array}{l}1 / 3 \text { to complete conversion to } \mathrm{H}_{2} \text { economy; } \\
\text { Assume surface } \mathrm{H}_{2} \text { mixing ratio } 1.4 \text { or } 2.3 \mathrm{ppm}\end{array}$ & $1-12 \%$ \\
\hline Jacobson et al. (2005) & $\begin{array}{l}5.68 \\
\text { (U.S. road } \\
\text { vehicle } \\
\text { emissions) }\end{array}$ & Switching U.S. vehicles to HFCVs in 1999 & $10 \%$ \\
\hline Derwent et al.(2006) & 25 & $100 \%$ replacement of fossil & $\begin{array}{c}1 \% \\
(1 \sim 10 \% \text { range }) \\
\end{array}$ \\
\hline Jacobson (2008) & $\begin{array}{l}4.82 \\
\text { (for world } \\
\text { road } \\
\text { vehicle } \\
\text { emissions) }\end{array}$ & $\begin{array}{l}1995 \text { world road vehicles } 100 \% \text { replaced by } \mathrm{H}_{2} \\
\text { fuel cells }\end{array}$ & $3 \%$ \\
\hline
\end{tabular}

Table 12. $\mathrm{H}_{2}$ break even leakage percentage for different cases (Unit: \%, other units: $\left.\mathrm{TgH}_{2} / \mathrm{yr}\right)$.

\begin{tabular}{|c|c|c|c|c|}
\hline Equal Efficiencies & 2050 A1FI & 2050 B1 & 2000_A1FI & 2000_B1 \\
\hline $\mathrm{H}_{2}$ emissions from fossil transportation & 14.8 & 3.2 & 6 & 6 \\
\hline Total $\mathrm{H}_{2}$ demand for road transportation & 2403.5 & 1101.3 & 556 & 486 \\
\hline $\mathrm{H}_{2}$ break even percentage & 0.6 & 0.3 & 1.1 & 1.2 \\
\hline
\end{tabular}

\begin{tabular}{|c|c|c|c|c|}
\hline $40 \%$ ICE / 60\% Fuel Cell Efficiencies & 2050 A1FI & 2050 B1 & 2000_A1FI & 2000_B1 \\
\hline $\mathrm{H}_{2}$ emissions from fossil transportation & 14.8 & 3.2 & 6 & 6 \\
\hline Total $\mathrm{H}_{2}$ demand for road transportation & 1602.3 & 734.2 & 193.5 & 169.1 \\
\hline $\mathrm{H}_{2}$ break even percentage & 0.9 & 0.4 & 3.1 & 3.5 \\
\hline
\end{tabular}

Table 13. Year $2050 \mathrm{CO}_{2}$ emissions for $\mathrm{A} 1 \mathrm{FI}$ and $\mathrm{B} 1$ baseline and $\mathrm{H}_{2}$ powered road transportation sector $\left(\mathrm{GtCO}_{2} / \mathrm{yr}\right)$.

\begin{tabular}{|c|c|c|c|}
\hline A1FI & HS0, HS1 & HS2, HS3 & Change [\%] \\
\hline Road Transportation & 22.1 & 0 & -100 \\
\hline Total Fossil & 84.7 & 62.6 & -26.1 \\
\hline
\end{tabular}




\begin{tabular}{|c|c|c|c|}
\hline B1 & HS0, HS1 & HS2, HS3 & Change [\%] \\
\hline Road Transportation & 10.1 & 0 & -100 \\
\hline Total Fossil & 42.9 & 32.8 & -23.5 \\
\hline
\end{tabular}




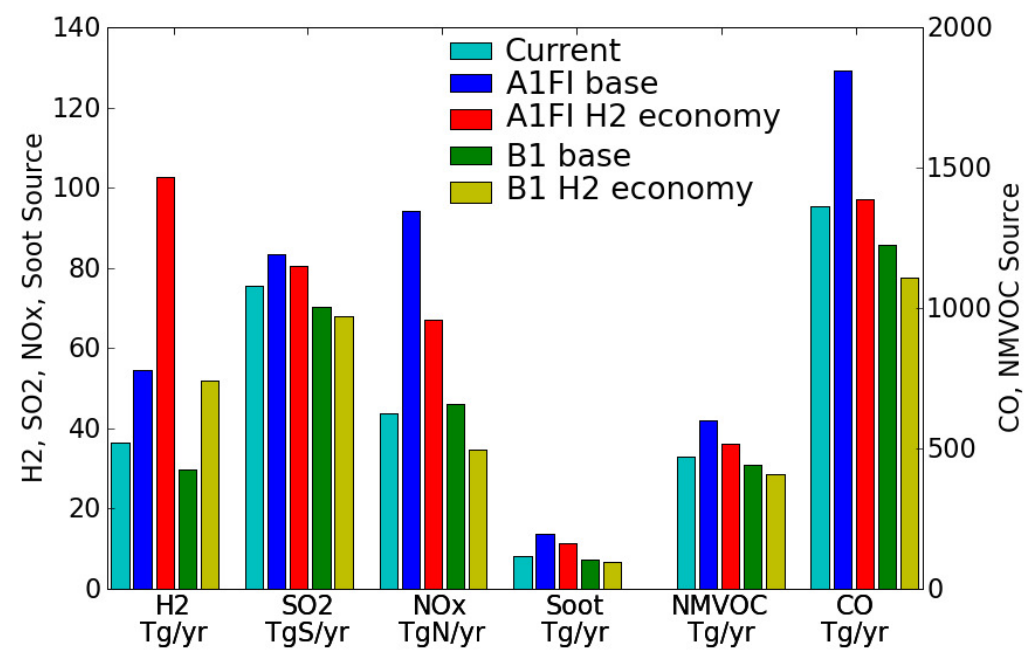

Figure 1. Global total emissions for the Current and A1FI and B1 HS0 baseline and $\mathrm{HS} 2 \mathrm{H}_{2}$-based fuel cell transportation sector scenarios.

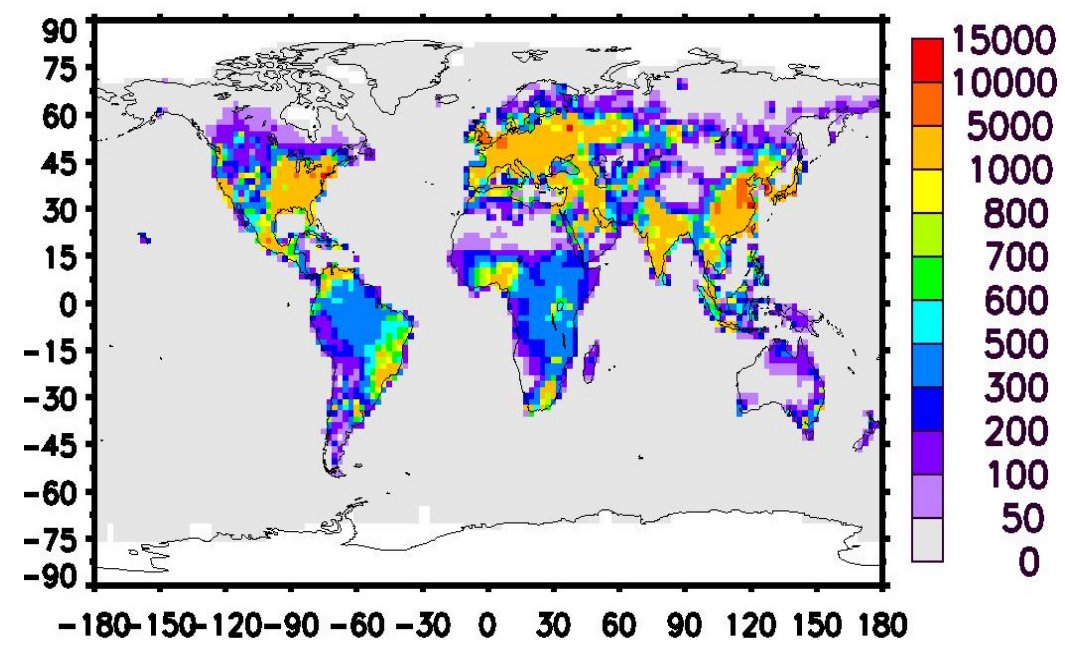

Figure 2. Annual average total $\mathrm{H}_{2}$ emissions for the 2050 A1FI (HS2) fuel cell adoption scenario.(Contour Units: $10^{9}$ molecules $\mathrm{cm}^{-2} \mathrm{~s}^{-1}$ ) 


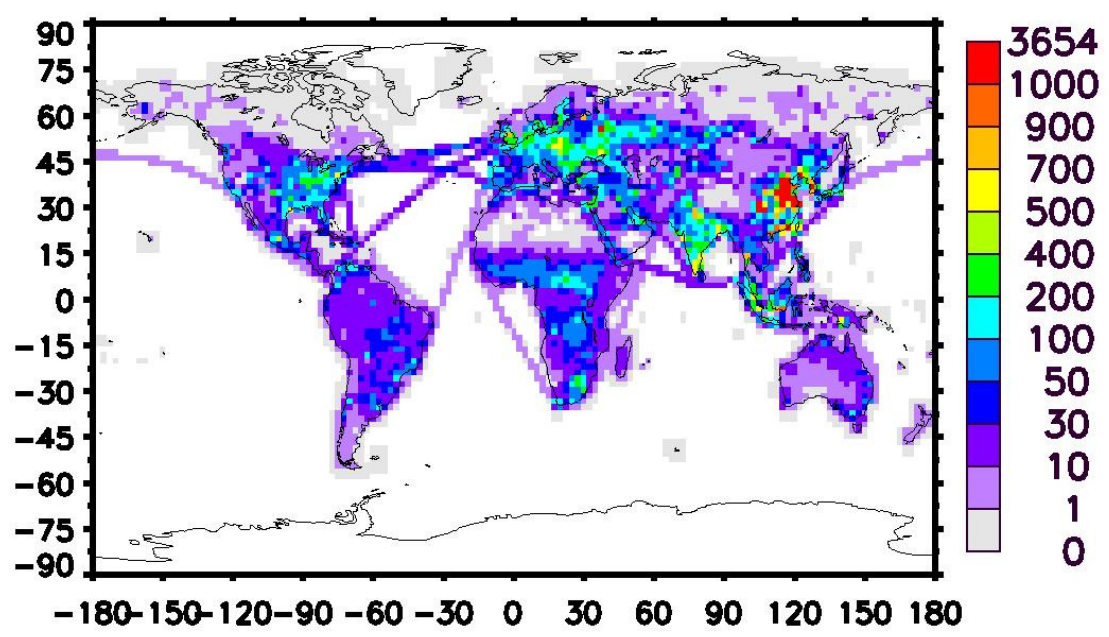

Figure 3. Annual average total NOx emissions for the 2050 A1FI (HS2) fuel cell adoption scenario. (Contour Units: $10^{9}$ molecules $\mathrm{cm}^{-2} \mathrm{~s}^{-1}$ )

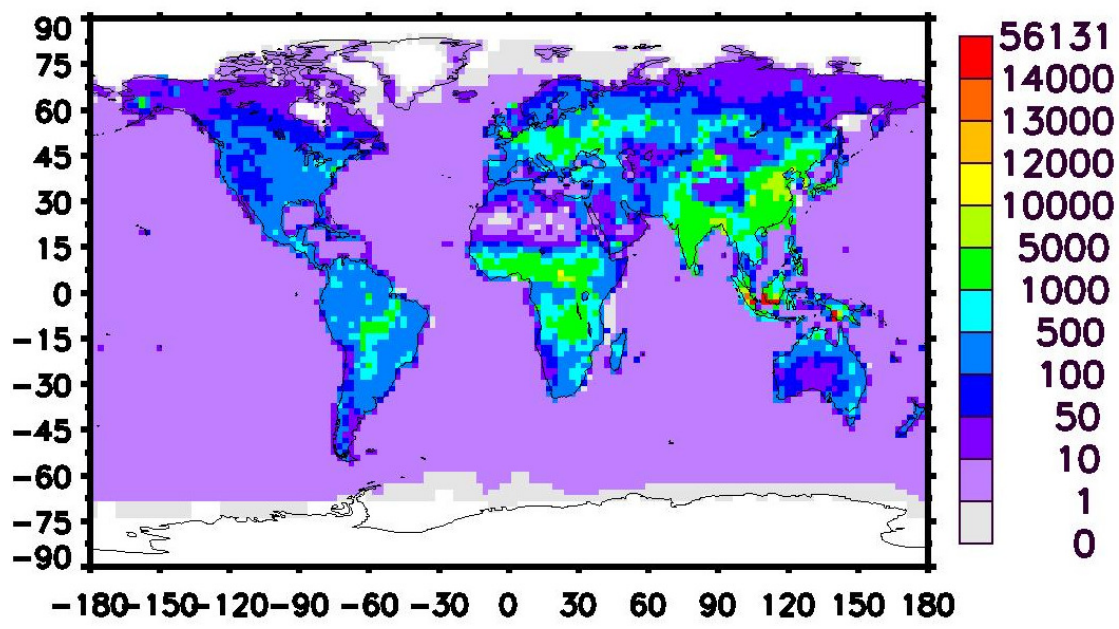

Figure 4. Annual average total CO emissions for the 2050 A1FI (HS2) fuel cell adoption scenario. (Contour Units: $10^{9}$ molecules $\mathrm{cm}^{-2} \mathrm{~s}^{-1}$ ) 


\title{
Section 2
}

\section{Impact of a Future Hydrogen-Based Road Transportation Sector on Tropospheric Composition and Chemistry}

\author{
Dong Wang, Wenjing Jia, Seth Olsen and Donald Wuebbles \\ Department of Atmospheric Sciences \\ University of Illinois at Urbana-Champaign
}

\section{Introduction}

Road traffic burning fossil fuels emits a number of gaseous pollutants, including nitrogen oxides $\left(\mathrm{NO}_{\mathrm{x}}\right)$, carbon monoxide $(\mathrm{CO})$ and volatile organic compounds (VOCs), which have been long recognized as major pollutants and subject to EPA regulation (http://www.epa.gov/air/airpollutants.html), as well as particulate matters (mainly soot, or black carbon). Studies have shown that soot imposes health hazards on respiratory system [e.g., Dockery et al., 1993], and contributes to global warming [e.g., Bond and Bergstrom, 2006]. In addition, ground level ozone $\left(\mathrm{O}_{3}\right)$, the "bad" ozone (http://www.epa.gov/air/ozonepollution/), forms through photochemical reactions involving $\mathrm{CO}$ and VOCs in the presence of $\mathrm{NO}_{\mathrm{x}}$ and sunlight (see the included Appendix for more information on tropospheric chemistry). Hydrogen $\left(\mathrm{H}_{2}\right)$ has been proposed as an alternative energy carrier which is much cleaner than fossil fuel. Vehicles powered by $\mathrm{H}_{2}$ fuel cells do not emit $\mathrm{NO}_{\mathrm{x}}, \mathrm{CO}$, VOCs or soot; the only substances they emit are water vapor and a small amount of $\mathrm{H}_{2}$ due to leakage during its production, transportation and storage processes. Vehicles powered by $\mathrm{H}_{2}$ internal combustion engines have no $\mathrm{CO}, \mathrm{VOC}$, and soot emissions. Given these reductions in emissions it is reasonably foreseeable that transitioning the world's road traffic from fossil fuel internal combustion engine (ICE) powered vehicles to $\mathrm{H}_{2}$ technology based would substantially improve air quality provided that the $\mathrm{H}_{2}$ is produced by nonpolluting methods, e.g., wind or solar power. Such a transition would take some time as substantial changes to energy delivery infrastructure and technology, and industrial $\mathrm{H}_{2}$ massive production capacity would be required. Here we quantitatively examine 
the possible impact of such a transition on tropospheric air quality, composition and chemistry in 2050 for two types of $\mathrm{H}_{2}$ technology $\left(\mathrm{H}_{2}\right.$ fuel cells and $\mathrm{H}_{2}$ internal combustion engines) in combination with two future growth paths. The future growth paths are based on the IPCC fossil fuel intensive A1FI scenario (high emitting) and the service and information intensive B1 scenario (low emitting) [IPCC, 2000], in order to bracket the possibilities of the world's future. The additional $\mathrm{H}_{2}$ emission will likely increase its abundance in the troposphere, but it should not raise an environmental concern in the troposphere. Its major tropospheric sink is deposition to soils and by reaction with atmospheric hydroxyl, producing water vapor but in amounts dwarfed by natural levels of water vapor.

\section{Method}

\subsection{Model Description}

For this study we use the Community Atmosphere Model with chemistry (CAM-

Chem) chemistry climate model [Lamarque et al., 2005; Heald et al., 2008; Pfister et al., 2008]. CAM-Chem was developed primarily at the National Center for Atmospheric Research (NCAR) in cooperation with the National Science Foundation (NSF), the Department of Energy (DoE), the National Aeronautics and Space Administration (NASA), and the University Corporation for Atmospheric Research (UCAR). CAM-Chem's chemistry module is based on the chemical component of the Model for OZone And Related chemical Tracers (MOZART) [Horowitz et al., 2003]. This mechanism contains a comprehensive tropospheric gas phase and aerosol chemical mechanism and includes 119 species and 300 reactions. For this study, the global atmosphere is divided into grids with a horizontal resolution of $1.9^{\circ}$ latitude by $2.5^{\circ}$ longitude, and with 26 vertical layers, extending from the surface to 3-millibar level (about $40 \mathrm{~km}$ altitude). The meteorology data is prescribed by climate model output data from Community Climate System Model (CCSM) which corresponds to the current climate state. After one year's calculation is completed, the meteorology field is repeated for the next year. This method allows the impact of changes in emissions to be investigated excluding the possible influences of changes in meteorology. The 2050 atmospheric $\mathrm{CH}_{4}$ concentration is determined by scaling the 
2000 atmospheric lower boundary $\mathrm{CH}_{4}$ concentration $(1760 \mathrm{ppb})$ to the concentration projected by IPCC, 2001 (2668 ppb and $1881 \mathrm{ppb}$ for A1FI and B1, respectively). The model is run for eight years and has reached steady state, that is, year-to-year relative difference of key species is less than $1 \%$.

Deposition to soil is an important sink ( 80\%) of $\mathrm{H}_{2}$ in the atmosphere. Despite its importance, the controlling factors of this deposition are not well characterized and are subject to large uncertainties. Observations have shown a strong correlation between the $\mathrm{H}_{2}$ and $\mathrm{CO}$ deposition velocities [Liebl and Seiler, 1976; Conrad and Seiler, 1985; Yonemura et al., 1999 and Yonemura et al., 2000]. Based on these studies we adopt an $\mathrm{H}_{2}$ deposition velocity equal to two times the $\mathrm{CO}$ deposition velocity. Others have proposed calculating $\mathrm{H}_{2}$ deposition velocities as a function of soil temperature, moisture content, and diffusivity [e.g., Smith-Downey et al., 2006]. However, it is not known if the relationship derived in these studies has global validity given the limited observations providing the basis for this approach. In addition, application of this relationship to the temperature range between 0 and $30^{\circ} \mathrm{C}$ contradicts the observational findings by Yonemura et al., [1999] and Yonemura et al., [2000]. Therefore, we model $\mathrm{H}_{2}$ dry deposition velocity $\left(\mathrm{V}_{\mathrm{d}}\right)$ to soils by using its correlation with $\mathrm{CO}$ dry deposition velocity. Based on observations we adopt a $\mathrm{V}_{\mathrm{d}}\left[\mathrm{H}_{2}\right]$ equal to two times $\mathrm{V}_{\mathrm{d}}[\mathrm{CO}]$, though there remain large uncertainties.

\subsection{Emission Scenarios}

Future growth scenarios are based on the highest and lowest IPCC emissions scenarios (IPCC, 2000), A1FI and B1, respectively. Given the large uncertainties in future projections, these scenarios were chosen since they bracket the possible high and low impacts. In the A1FI scenario, the world is assumed to evolve with rapid economic growth and rely intensively on fossil fuel; whereas in the B1 scenario the world's economic structures are projected to change rapidly toward service-andinformation intensive society. For each of these two IPCC growth scenarios four emission scenarios were developed: 
1) Baseline (BL) scenario: reference scenario for 2050.

2) Baseline $+\mathrm{H}_{2}\left(\mathrm{BL}+\mathrm{H}_{2}\right)$ scenario: energy demands of the road transportation sector are met by $\mathrm{H}_{2}$ and leakage of $\mathrm{H}_{2}$ to the atmosphere is included but other emissions remain the same as in the BL scenario. This scenario, though not realistic, allows the evaluation of the impact of $\mathrm{H}_{2}$ emission alone on tropospheric composition and chemistry.

3) $\mathrm{H}_{2}$ Fuel Cell $\left(\mathrm{H}_{2}\right.$-FC) scenario: energy demands of the road transportation sector are met by $\mathrm{H}_{2}$ fuel cell technology. In this scenario emissions due to $\mathrm{H}_{2}$ leakage as well as reductions in combustion-related emissions of $\mathrm{NO}_{\mathrm{x}}, \mathrm{VOCs}, \mathrm{CO}, \mathrm{SO}_{2}$ and soot are included.

4) $\mathrm{H}_{2}$ Internal Combustion Engine $\left(\mathrm{H}_{2}\right.$-ICE) scenario: energy demands of the road transportation sector are met by $\mathrm{H}_{2}$ using internal combustion technology. In this scenario emissions due to $\mathrm{H}_{2}$ leakage as well as reductions in combustion-related emissions of VOCs, $\mathrm{CO}, \mathrm{SO}_{2}$ and soot are included, however there are no reductions in $\mathrm{NO}_{\mathrm{x}}$ emissions.

These emissions are input to the model as monthly varying maps at the model resolution. Annual global emissions of key species are summarized in Figures 1 and 2. In 2050, for the A1FI scenario an $\mathrm{H}_{2}$-based transportation sector would decrease global CO, NMVOCs ${ }^{*}, \mathrm{NO}_{\mathrm{x}}, \mathrm{SO}_{2}$ and soot emissions by $25 \%, 14 \%, 29 \%\left(\mathrm{H}_{2}-\mathrm{FC}\right)$ or $0 \%\left(\mathrm{H}_{2}-\mathrm{ICE}\right), 3 \%$ and $17 \%$ whereas increase $\mathrm{H}_{2}$ emissions by $81 \%$. For the B1 scenario an $\mathrm{H}_{2}$-based transportation sector would decrease global CO, NMVOCs $\mathrm{NO}_{\mathrm{x}}$, $\mathrm{SO}_{2}$ and soot emissions by $10 \%, 8 \%, 24 \%\left(\mathrm{H}_{2}-\mathrm{FC}\right)$ or $0 \%\left(\mathrm{H}_{2}-\mathrm{ICE}\right), 3 \%$ and $8 \%$ while increase $\mathrm{H}_{2}$ emissions by $64 \%$. For more details about the emission changes, please refer to our companion report on emissions.

\section{Results}

Our modeling studies suggest that in the experimental scenarios assuming only added $\mathrm{H}_{2}$ emission without related emissions changes ( $\mathrm{BL}+\mathrm{H}_{2}$ scenarios) the added $\mathrm{H}_{2}$ alone

\footnotetext{
* NMVOCs: non-methane volatile organic compounds
} 
has little impact on tropospheric chemistry except for a significant rise in atmospheric $\mathrm{H}_{2}$ concentration. Air quality improves significantly (significant reductions in concentrations of $\mathrm{O}_{3}, \mathrm{CO}, \mathrm{NO}_{\mathrm{x}}$ and particulate matters) in $\mathrm{H}_{2}-\mathrm{FC}$ scenarios. Air quality improves considerably (significant reductions in concentrations of $\mathrm{CO}$ and particulate matters) in $\mathrm{H}_{2}$-ICE scenarios.

The projected mean tropospheric concentrations of chemical species of interest in the BL scenarios and the projected changes of concentrations in the $\mathrm{H}_{2}$ scenarios relative to those in the corresponding BL scenarios are summarized in Tables 1 and 2. For the A1FI scenarios, tropospheric $\mathrm{H}_{2}$ burden (total $\mathrm{H}_{2}$ in the troposphere) would be about $40 \%$ higher in the $\mathrm{H}_{2}$ scenarios than that in the BL (Table 1). Concentrations of gaseous species and particulate matters of air quality concern decrease significantly. Tropospheric $\mathrm{O}_{3}, \mathrm{CO}, \mathrm{NO}_{\mathrm{x}}$, soot, sulfate aerosols and secondary organic aerosols burdens decrease by $7 \%, 14 \%, 16 \%, 17 \%, 4 \%$ and $12 \%$ in the $\mathrm{A} 1 \mathrm{FI} \mathrm{H}_{2}-\mathrm{FC}$ scenario. Tropospheric $\mathrm{O}_{3}, \mathrm{CO}$, soot, sulfate aerosols and secondary organic aerosols burdens decrease by $1 \%, 18 \%, 17 \%, 3 \%$ and $18 \%$ in the $\mathrm{A} 1 \mathrm{FI} \mathrm{H} \mathrm{H}_{2}$-ICE scenario. The $\mathrm{BL}+\mathrm{H}_{2}$, $\mathrm{H}_{2}-\mathrm{FC}$ and $\mathrm{H}_{2}-\mathrm{ICE}$ scenarios change the tropospheric $\mathrm{OH}$ abundance by $-2 \%,-4 \%$ and $+7 \%$, respectively.

For the $\mathrm{B} 1$ scenarios, tropospheric $\mathrm{H}_{2}$ burden would be increased by approximately $20 \%$ in the $\mathrm{H}_{2}$ scenarios (Table 2). Tropospheric $\mathrm{O}_{3}, \mathrm{CO}, \mathrm{NO}_{x}$, soot, sulfate aerosols and secondary organic aerosols burdens decrease by $5 \%, 4 \%, 11 \%, 7 \%, 4 \%$ and $3 \%$ in the $\mathrm{B} 1 \mathrm{H}_{2}$-FC scenario. Tropospheric $\mathrm{O}_{3}$, $\mathrm{CO}$, soot, sulfate aerosols and secondary organic aerosols burdens decrease by $1 \%, 7 \%, 7 \%, 3 \%$ and $9 \%$ in the $\mathrm{B} 1 \mathrm{H}_{2}$-ICE scenario. The $\mathrm{BL}+\mathrm{H}_{2}, \mathrm{H}_{2}-\mathrm{FC}$ and $\mathrm{H}_{2}$-ICE scenarios change the tropospheric $\mathrm{OH}$ abundance by $-1 \%,-4 \%$ and $+3 \%$, respectively. The magnitudes of relative changes in the $\mathrm{B} 1$ scenarios are less than those in the A1FI scenarios because B1 is a service and information intensive society in which energy demands by transportation sector are smaller than those in A1FI. 
In the following section individual atmospheric species of interest will be discussed in detail.

\section{$3.1 \mathrm{H}_{2}$}

In the $\mathrm{H}_{2}$ scenarios $\left(\mathrm{BL}+\mathrm{H}_{2}, \mathrm{H}_{2}-\mathrm{FC}\right.$ and $\left.\mathrm{H}_{2}-\mathrm{ICE}\right)$ the projected tropospheric mean $\mathrm{H}_{2}$ concentrations are around $1150 \mathrm{ppb}^{*}(\mathrm{~A} 1 \mathrm{FI})$ and $740 \mathrm{ppb}(\mathrm{B} 1)$, which are equivalent to an increase from the BL scenarios by $40 \%$ and $20 \%$, respectively. In other words, compared with today's atmosphere, tropospheric $\mathrm{H}_{2}$ concentration would be 2.2 (A1FI) or 1.5 (B1) times the current value (around $500 \mathrm{ppb}$ ). The increase in molecular hydrogen abundance would not cause much environmental concern because of $\mathrm{H}_{2}$ 's low chemical reactivity in the troposphere.

In the $2050 \mathrm{~A} 1 \mathrm{FI} \mathrm{BL}$ scenario ground-level annual-mean $\mathrm{H}_{2}$ mixing ratio over the world would be around $800 \mathrm{ppb}$ (Figure.3), with maxima in highly urbanized and/or industrialized regions like northeastern U.S., southern California, Western Europe, Korean peninsula, Japan and eastern China. Lowest $\mathrm{H}_{2}$ mixing ratios (about 700 ppb) would appear over mid-latitude continents of the southern hemisphere, reflecting both small human $\mathrm{H}_{2}$ source and large $\mathrm{H}_{2}$ soil sink in those regions.

Because of its long chemical lifetime in the troposphere, the patterns of ground $\mathrm{H}_{2}$ concentrations, primarily determined by its human source, resemble each other much in the $\mathrm{H}_{2}$ scenarios. This similarity allows us to examine the $\mathrm{H}_{2}-\mathrm{FC}$ scenario as an example of the $\mathrm{H}_{2}$ societies. The projected inter-hemispheric $\left[\mathrm{H}_{2}\right]^{* *}$ gradient is opposite to that for today's atmosphere - higher background $\mathrm{H}_{2}$ abundance (around $1.2 \mathrm{ppm}$ ) is observed in the northern hemisphere, comparing with some $1.15 \mathrm{ppm}$ in the southern hemisphere. This reflects the larger forcing of $\mathrm{H}_{2}$ emission from human activities (more intensive in the northern hemisphere) on hemispheric $\mathrm{H}_{2}$ concentrations. The background surface $\mathrm{H}_{2}$ mixing ratio increases at least $40 \%$ in the

\footnotetext{
* ppb: parts per billion by volume.
} 
northern hemisphere and $35 \%$ in the southern hemisphere. Highest mixing ratio (more than $1.6 \mathrm{ppm}$ ) occurs in eastern China and Korea, corresponding to a more than $75 \%$ increase from the BL scenario (Figure. 3). In northeastern U.S., $\left[\mathrm{H}_{2}\right]$ increases by $50 \%$.

In the $\mathrm{B} 1 \mathrm{BL}$ scenario, ground-level annual-mean $\mathrm{H}_{2}$ mixing ratio over the world is projected to be around $600 \mathrm{ppb}$ in 2050 (Figure. 4), showing no regions with significantly high value. In the $\mathrm{H}_{2}$-FC scenario, a representative of the $\mathrm{H}_{2}$ scenarios, ground-level $\mathrm{H}_{2}$ mixing ratio is projected to be around $700 \mathrm{ppb}$ in both hemispheres. The background surface $\mathrm{H}_{2}$ mixing ratio would increase from the BL scenario by more than $20 \%$ in the northern hemisphere and by more than $16 \%$ in the southern hemisphere (Figure.4). Maximum mixing ratio (more than $860 \mathrm{ppb}$ ) appears in eastern Asia, corresponding to a more than $40 \%$ increase from the BL. The pattern of relative increase of zonal mean $\mathrm{H}_{2}$ mixing ratio in $\mathrm{H}_{2}$ societies relative to the non- $\mathrm{H}_{2}$ society is similar to that in the corresponding A1FI scenarios, except that the magnitude of increase is smaller.

From a zonal mean perspective, $\left[\mathrm{H}_{2}\right]$ is increased throughout the troposphere in the $\mathrm{H}_{2}$ scenarios (Figures.5 and 6). In the A1FI BL scenario, inter-hemispheric $\left[\mathrm{H}_{2}\right]$ gradient would have already reversed from today's with higher $\left[\mathrm{H}_{2}\right]$ in the northern hemisphere $(\mathrm{NH})$ since enhanced human activities in the $\mathrm{NH}$ would place a larger forcing on atmospheric $\left[\mathrm{H}_{2}\right]$ (Figure.5). An $\mathrm{H}_{2}$-based road transportation sector would even sharpen the inter-hemispheric $\left[\mathrm{H}_{2}\right]$ gradient by increasing $\left[\mathrm{H}_{2}\right]$ more in the NH. The largest increase $(\sim 45 \%)$ occurs near surface in the mid-latitudes of the NH (Figure. 5), demonstrating intensive human activities there.

Whereas in the B1 BL scenario, inter-hemispheric $\left[\mathrm{H}_{2}\right]$ gradient would be the same with today's with higher $\left[\mathrm{H}_{2}\right]$ in the southern hemisphere $(\mathrm{SH})$ since enhanced human

\footnotetext{
${ }^{* *}[\mathrm{X}]$ represents species $\mathrm{X}$ 's mixing ratio.
} 
activities in the $\mathrm{NH}$ would place a forcing strong enough on atmospheric $\left[\mathrm{H}_{2}\right]$ (Figure.6). However, in the $\mathrm{B} 1 \mathrm{H}_{2}$ scenarios, this gradient would be reversed as a result of enhanced $\mathrm{H}_{2}$ emission.

\subsection{Ozone}

Tropospheric ozone is an air pollutant and a greenhouse gas. Addition of $\mathrm{H}_{2}$ alone to the atmosphere does not directly affect tropospheric ozone abundance. However, significant ozone mitigation can be achieved if an $\mathrm{H}_{2}$-based road transportation sector is implemented in combination with $\mathrm{CO}, \mathrm{NO}_{\mathrm{x}}$ and $\mathrm{NMVOCs}$ emissions reduction.

In the three $\mathrm{H}_{2}$ scenarios, $\mathrm{H}_{2}$-FC would achieve the most ozone reductions, whereas there is almost no change in ozone mixing ratio in $\mathrm{BL}+\mathrm{H}_{2}$, and ozone is slightly reduced in $\mathrm{H}_{2}$-ICE.

In the A1FI BL scenario, annual mean surface ozone concentration over land in 2050 is projected to be mostly above $30 \mathrm{ppb}$ (Figure.7). Higher ozone mixing ratios, resulting from $\mathrm{NO}_{\mathrm{x}}, \mathrm{NMVOCs}$ and $\mathrm{CO}$ emissions due to fossil fuel combustion, are seen in densely populated areas. In the $\mathrm{H}_{2}-\mathrm{FC}$ scenario, ozone mixing ratios $5 \sim 10 \mathrm{ppb}$ lower than those in BL are seen over these areas. Ozone reductions are most effective in summertime, when ozone pollution is most severe. In terms of relative change, ozone decreases by more than $6 \%$ over the world, with as much as $20 \%$ decrease in Latin America and Southeast Asia. However, there is increased ozone in some extremely populated areas such as New York, London and South Korea (Figure. 7). This is because in these regions NOx-VOC ratio belongs to VOC limited scheme (Figure.8), i.e., decreasing both $\mathrm{NO}_{\mathrm{x}}$ and VOC emission is not effective in ozone mitigation, because VOC mixing ratio is the limiting factor. In the $\mathrm{A} 1 \mathrm{FI} \mathrm{H}_{2}-\mathrm{FC}$ scenario, the annual, zonal average ozone mixing ratios are generally decreased by more than 5\% (Figure. 9) in the lower troposphere. Peak decrease (more than 10\%) appears near surface at the low latitudes of northern hemisphere. 
In the $\mathrm{A} 1 \mathrm{FI} \mathrm{H}_{2}$-ICE scenario surface ozone concentration decline compared with the base scenario is generally not as apparent as in the A1FI $\mathrm{H}_{2}$-FC scenario (Figure.7). In contrast to the $\mathrm{A} 1 \mathrm{FI} \mathrm{H}_{2}-\mathrm{FC}$ scenario, in those regions where ozone reduction is not apparent in $\mathrm{H}_{2}-\mathrm{FC},\left[\mathrm{O}_{3}\right]$ decreases considerably, suggesting that in these regions VOC emission reductions are more effective in ozone pollution mitigation. The zonal mean ozone concentrations do not change significantly except in the lower troposphere of the northern middle latitudes, where ozone decreases by 5\% (Figure. 9).

For the B1 BL scenario, the distribution pattern of annual mean near surface ozone concentrations over the world is similar to that for the corresponding A1FI scenarios, but as can be expected from B1's lower emissions, the absolute concentrations are lower (Figure. 10). In the $\mathrm{B} 1 \mathrm{H}_{2}$-FC scenario, annual mean near surface ozone decreases significantly (more than 10\%) in the southern part of the U.S. and along the East Coast. Ozone reductions in the $\mathrm{B} 1 \mathrm{H}_{2}-\mathrm{ICE}$ scenario are not as apparent (Figure. $11)$.

\subsection{OH radicals}

A major concern over the potential impact of an $\mathrm{H}_{2}$-based road transportation sector on tropospheric chemistry is that the added molecular hydrogen in the atmosphere would titrate $\mathrm{OH}$ radicals so as to impair the oxidizing power of the atmosphere. Model simulations show that adding only $\mathrm{H}_{2}$ to the atmosphere would only reduce $\mathrm{OH}$ abundance in the troposphere by $2 \%$. Greater impact is seen when combined with concomitant reductions of ozone precursors $\left(\mathrm{NO}_{\mathrm{x}}, \mathrm{CO}\right.$ and NMVOCs) emissions $[\mathrm{OH}]$ decreases by $4 \%$ in both the $\mathrm{A} 1 \mathrm{FI}$ and $\mathrm{B} 1 \mathrm{H}_{2}-\mathrm{FC}$ scenarios. When only reducing $\mathrm{CO}$ and NMVOCs emissions as in the $\mathrm{H}_{2}$-ICE scenarios, tropospheric $\mathrm{OH}$ abundance would increase (by $7 \%$ for A1FI and by $3 \%$ for B1) instead of decrease, because there are less VOC sinks for $\mathrm{OH}$.

$\mathrm{H}_{2}$ itself does not significantly impact on the abundance of $\mathrm{OH}$ in the troposphere. In the experimental simulation in which only additional $\mathrm{H}_{2}$ emission is considered (A1FI 
$\mathrm{BL}+\mathrm{H} 2$ scenario), tropospheric $\mathrm{OH}$ concentrations are decreased by as much as $3 \%$

(Figure.12). The largest decrease is observed in the lower troposphere of the southern hemisphere.

In the more realistic $\mathrm{H}_{2}$ scenario ( $\mathrm{A} 1 \mathrm{FI} \mathrm{H}_{2}-\mathrm{FC}$ ), $\mathrm{OH}$ decrease is more apparent than in $\mathrm{BL}+\mathrm{H}_{2}$ as a consequence of decreased ozone concentration (Figure.12). The maximum $\mathrm{OH}$ concentration decline (more than 20\%) would be predicted in the lower troposphere of the southern mid-latitudes. Around $10 \% \mathrm{OH}$ increase is observed in the free troposphere at northern high-latitudes in boreal spring. However, this is not important since the base $\mathrm{OH}$ concentration is low in this region.

In the $\mathrm{A} 1 \mathrm{FI} \mathrm{H}_{2}$-ICE scenario, $\mathrm{OH}$ concentrations in most of the troposphere increases by more than $5 \%$ (Figure. 12). The troposphere $\mathrm{OH}$ burden increases by $7 \%$. OH increases by over $30 \%$ in the middle troposphere at $60^{\circ} \mathrm{N}$, as a result of almost unchanged ozone concentrations and significantly decreased VOCs (OH sinks) abundances.

For the $\mathrm{B} 1$ scenarios the patterns of $\mathrm{OH}$ concentration changes are similar to those of the corresponding A1FI scenarios but the magnitude of impact is smaller (Figure. 13).

\section{$3.4 \mathrm{NO}_{\mathrm{x}}$}

$\mathrm{NO}_{\mathrm{x}}$ concentration does not change if only atmospheric $\mathrm{H}_{2}$ concentration increases

$\left(\mathrm{BL}+\mathrm{H}_{2}\right.$ scenarios). When $\mathrm{CO}, \mathrm{NO}_{\mathrm{x}}$ and NMVOCs emissions are mitigated $\left(\mathrm{H}_{2}-\mathrm{FC}\right.$ scenarios), $\left[\mathrm{NO}_{\mathrm{x}}\right]$ are reduced significantly. However, model predicts that tropospheric $\left[\mathrm{NO}_{\mathrm{x}}\right]$ increases if only $\mathrm{CO}$ and NMVOCs emissions are reduced while $\mathrm{NO}_{\mathrm{x}}$ emissions keep unchanged $\left(\mathrm{H}_{2}\right.$-ICE scenarios).

Regions with intense human activities are polluted with high concentrations of $\mathrm{NO}_{\mathrm{x}}$. In the $\mathrm{H}_{2}$ scenario with $\mathrm{NO}_{\mathrm{x}}$ emission mitigation $\left(\mathrm{H}_{2}-\mathrm{FC}\right)$, those high $\left[\mathrm{NO}_{\mathrm{x}}\right]$ regions would benefit from substantial $\left[\mathrm{NO}_{\mathrm{x}}\right]$ reduction. Annual mean ground level $\left[\mathrm{NO}_{\mathrm{x}}\right]$ is 
reduced considerably along coasts of North and South Americas, Western Europe, North Africa, the Middle East and Japan (Figure.14). Relative reduction can be as high as $60 \%$, such as in California. The relative reduction is most obvious in wintertime. From zonal mean perspective, $\mathrm{NO}_{\mathrm{x}}$ concentrations decline throughout the lower troposphere (Figure.15). Maximum reductions appear in the boundary layer between $30^{\circ} \mathrm{S}$ and $60^{\circ} \mathrm{S}$ and between $0^{\circ}$ and $60^{\circ} \mathrm{N}$. In the A1FI $\mathrm{H}_{2}$-ICE scenario, near surface $\mathrm{NO}_{\mathrm{x}}$ concentration change is not apparent, showing that the internal combustion engine type of $\mathrm{H}_{2}$ society is not effective in ground level $\mathrm{NO}_{\mathrm{x}}$ mitigation. In the middle and upper troposphere there is a $\left[\mathrm{NO}_{\mathrm{x}}\right]$ increase because its sink against VOCs is reduced since NMVOC emissions are reduced.

For the $\mathrm{B} 1$ scenarios, we see similar annual mean ground level $\mathrm{NO}_{\mathrm{x}}$ mixing ratio relative change pattern in the $\mathrm{H}_{2}$-FC scenario, but the reductions are to a lesser extent than in the counterpart of the A1FI scenarios (Figure.16 and17).

\subsection{CO}

Atmospheric $\mathrm{H}_{2}$ concentration increase has little impact on $\mathrm{CO}\left(\mathrm{BL}+\mathrm{H}_{2}\right.$ scenarios). In the $\mathrm{H}_{2}$-FC and $\mathrm{H}_{2}$-ICE scenarios tropospheric $\mathrm{CO}$ burden decreases by $14 \sim 18 \%$ for A1FI, and by $4 \sim 7 \%$ for $\mathrm{B} 1 . \mathrm{H}_{2}$-ICE scenarios are generally more efficient in $\mathrm{CO}$ reduction than $\mathrm{H}_{2}-\mathrm{FC}$.

For the A1FI scenarios, $\mathrm{CO}$ concentrations in remote areas of the northern hemisphere decreases by more than $20 \%$ (Figure.18). Relative [CO] reductions in the $\mathrm{H}_{2}-\mathrm{FC}$ scenario are most apparent in urbanized and/or industrialized regions, such as northeastern U.S., California, central and western Europe, the Middle East, South Korea and Japan. New York City can have as much as $80 \%$ less [CO] in the air. The [CO] reduction is perennial but is most pronounced in winter. In the $\mathrm{H}_{2}$-ICE scenario

ground level $[\mathrm{CO}]$ reduction pattern is similar to that in the $\mathrm{A} 1 \mathrm{FI} \mathrm{H}_{2}-\mathrm{FC}$ scenario, but the magnitude of reduction is even larger, demonstrating that $\mathrm{H}_{2}$ internal combustion engines are more effective than $\mathrm{H}_{2}$ fuel cells in terms of $\mathrm{CO}$ mitigation. 
From the zonal mean perspective, [CO] reduction patterns are similar in $\mathrm{H}_{2}$ scenarios, with increasing magnitude of reduction from the south to the north (Figure.19). We see more reduction in $\mathrm{H}_{2}$-ICE than in $\mathrm{H}_{2}$-FC. This is because there is more $\mathrm{OH}$ in the troposphere in $\mathrm{H}_{2}$-ICE than in $\mathrm{H}_{2}-\mathrm{FC}$. And reaction against $\mathrm{OH}$ is the major sink of atmospheric $\mathrm{CO}$.

In the $\mathrm{B} 1 \mathrm{H}_{2}$-FC and $\mathrm{H}_{2}$-ICE scenarios, $\mathrm{CO}$ concentrations at remote sites in the northern hemisphere decrease by more than $10 \sim 20 \%$. The maximum reduction appears over northeastern U.S. (Figure.20), but not as significant in magnitude as in the A1FI corresponding scenario. The zonal mean [CO] reductions in $\mathrm{B} 1 \mathrm{H}_{2}$ scenarios are smaller than those in the corresponding A1FI scenarios (Figure.21).

\subsection{Aerosols}

Our model simulations show that merely increasing atmospheric $\mathrm{H}_{2}$ concentration (BL+H2 scenarios) has little impact on aerosols. For the $\mathrm{H}_{2}-\mathrm{FC}$ and $\mathrm{H}_{2}$-ICE scenarios, tropospheric aerosols, especially soot, sulfate aerosols and secondary organic aerosols concentrations are significantly reduced as a result of emissions mitigation. $\mathrm{H}_{2}-\mathrm{FC}$ scenarios have similar soot and $\mathrm{SO}_{4}$ reductions efficiency with that of the $\mathrm{H}_{2}$-ICE scenarios. Hereby we take the $\mathrm{H}_{2}-\mathrm{FC}$ scenario as a representative of an $\mathrm{H}_{2}$-based road transportation sector scenario for detailed soot and $\mathrm{SO}_{4}$ analysis.

\subsubsection{Soot}

Mass concentration of soot decreases by around $17 \%$ for the A1FI scenarios, and by $7 \%$ for the B1 scenario (Tables.1 and 2). Since soot is a product of fossil fuel combustion its pollution is highly localized. Its concentrations in remote atmosphere near the surface are rather low, whereas there are high soot concentrations in regions where human activities are intensive (Figure. 22). If the world evolves along the A1FI scenario, in 2050 soot pollution would be most severe in eastern China. Considerable 
soot pollution would also be seen in India, Europe. In the Midwest and eastern U.S. annual mean near surface soot concentration would be around $2 \mu \mathrm{g} / \mathrm{m}^{3}$.

In the $\mathrm{A} 1 \mathrm{FI} \mathrm{H}_{2}-\mathrm{FC}$ scenario (as above-mentioned the A1FI $\mathrm{H}_{2}$-ICE scenario is very similar to $\mathrm{H}_{2}-\mathrm{FC}$ scenario in terms of soot pollution), ground level soot can be significantly reduced in most regions of the U.S., Europe and Japan (Figure. 22). In interior U.S. regions and Western Europe, the reduction can be as much as more than $50 \%$ in comparison with the A1FI BL scenario. Reduction of soot in eastern Asia is not apparent. The soot pollution mitigation is most obvious in wintertime.

From the zonal mean view, soot concentration decrease is predicted at high latitudes of both hemispheres (Figure. 23) in the $\mathrm{H}_{2}$-FC scenario, with the largest decline in the northern hemisphere.

In the $\mathrm{B} 1$ scenarios soot reductions in the $\mathrm{H}_{2}-\mathrm{FC}$ and $\mathrm{H}_{2}$-ICE scenarios are less in magnitude but still significant than in the corresponding A1FI scenarios (Figures.24 and 25).

\subsection{2 $\mathrm{SO}_{4}$}

Sulfate aerosols $\left(\mathrm{SO}_{4}\right)$ decreases by $4 \%$ by mass for both the A1FI and $\mathrm{B} 1 \mathrm{H}_{2}-\mathrm{FC}$ scenarios; it decreases by $3 \%$ for both the A1FI and $\mathrm{B} 1 \mathrm{H}_{2}$-ICE scenario (Tables. 1 and 2). In the A1FI $\mathrm{H}_{2}$-FC scenario, there is around 10\%-15\% decrease in $\mathrm{SO}_{4}$ mass concentration comparing with the A1FI BL scenario over most Eurasia, North Africa, western and southern U.S., Mexico, and South America (Figure. 26). Zonal mean $\mathrm{SO}_{4}$ concentration decreases more in the $\mathrm{NH}$ (Figure. 27). $\mathrm{SO}_{4}$ mass concentrations are also decreased, but to a lesser extent, in the $\mathrm{B} 1 \mathrm{H}_{2}$ scenarios (Figures.28 and 29).

\subsubsection{SOA}

Secondary organic aerosols (SOA) contribute to a significant part of ambient tropospheric aerosols. There would be declines in SOA concentrations in the 
scenarios with an $\mathrm{H}_{2}$-base road transportation sector: tropospheric SOA mass concentration decreases by around 12 18\% for the A1FI scenarios and by 3 9\% for the B1 scenarios (Tables.1 and 2). Here the lower-end decline represents the $\mathrm{H}_{2}-\mathrm{FC}$ scenarios whereas the higher-end decline represents the $\mathrm{H}_{2}$-ICE scenarios. $\mathrm{H}_{2}$-based road transportation sector with $\mathrm{H}_{2}$ internal combustion engines application is more efficient in SOA reduction than that with $\mathrm{H}_{2}$ fuel cells.

In the $\mathrm{A} 1 \mathrm{FI} \mathrm{H}_{2}$-FC scenario, there is a significant decrease in SOA mass concentration (more than 30\%) over a broad band at northern mid-latitudes (Figure. 30). Whereas in the A1FI $\mathrm{H}_{2}$-ICE scenario, it decrease is even more than the $\mathrm{H}_{2}-\mathrm{FC}$ scenario (more than $40 \%$ in the northern hemisphere. SOA mass concentrations are decreased by a smaller magnitude in $\mathrm{B} 1 \mathrm{H}_{2}$ societies than in A1FI (Figures.32 and 33).

\section{Comparison with other studies}

Because of diverse scenario assumptions, it is hard to directly compare with other studies. Nevertheless, it would provide helpful comparisons if we assume linear tropospheric chemical response and use scaling method. In our study, $2 \% \mathrm{OH}$ concentration decrease results from $40 \%$ of $\mathrm{H}_{2}$ concentration increase. Using a twodimensional model to carry out a somewhat ideal modeling experiment, Warwick et al. [2004] find quadrupling atmospheric $\mathrm{H}_{2}$ concentrations leads to $10 \%$ decrease in $\mathrm{OH}$ concentrations, which is in good agreement if scale our study. They also obtain $2.2 \%$ decrease of tropospheric ozone in current atmosphere if converted to $\mathrm{H}_{2}$ society. While the divergence of the emission scenarios in their study from ours nulls direct comparison, it would be helpful noting that ozone is predicted to be $2.2 \%$ less in $\mathrm{H}_{2}$ society according to Warwick et al.

Assuming half of current fossil fuel combustion changed to $\mathrm{H}_{2}$ technology, Schultz et al. [2003] find 5\% decrease in tropospheric ozone, in a 3-D modeling study. Their predicted regions with most ozone reductions overlap those predicted by our study. Just as shown in our study, they have also captured the increase in surface ozone near London, New York City, and Korea. 
Jacobson et al. [2005] find substantial ozone decrease in southeastern U.S. in a natural gas type $\mathrm{H}_{2}$ society. However, there is discrepancy in prediction of soot reduction. We predict most apparent reductions appear in interior U.S. while Jacobson et al. find largest decline in southeastern U.S. This discrepancy is likely to arise from the different scenarios used in the two studies. In a subsequent study Jacobson [2008] shows similar characteristics of air quality improvement in $\mathrm{H}_{2}$ society with our study.

Ignoring $\mathrm{H}_{2}$ 's impact on troposphere chemistry (its impact has been shown to be small in our study), the environmental effect of $\mathrm{H}_{2}$ society is much like that of removal of traffic emissions. A number of studies [Mattes et al., 2007; Niemeier et al., 2006; Hoor et al. 2009] examine the impact of road traffic emissions on troposphere chemistry, by comparing the atmosphere chemistry with and without road traffic emissions. The abatement of air pollution in $\mathrm{H}_{2}$ society in our study is at the opposite sign of air quality degradation when adding road emissions in the above-mentioned studies, although we are doing simulations about the future while these studies focus on the current atmosphere. This suggests our results are consistent with these studies.

\section{Conclusions}

A set of numerical simulations using a three-dimensional global atmospheric chemistry and transport model have been carried out in order to study potential impact of a future (year 2050) $\mathrm{H}_{2}$-based road transportation sector on tropospheric composition and chemistry. The assumptions in the modeling studies include highand low-emitting future scenarios to bracket possible growth paths, and a set of $\mathrm{H}_{2}$ technology option scenarios.

Atmospheric simulations assuming only $\mathrm{H}_{2}$ emission without related emissions change ( $\mathrm{BL}+\mathrm{H}_{2}$ scenarios) show that $\mathrm{H}_{2}$ by itself has little impact on tropospheric chemistry except for significant rise in tropospheric $\mathrm{H}_{2}$ concentration, which should 
raise no environmental concern as it is not toxic (however, it does lead to questions about effects on the stratosphere addressed in a separate report).

Air quality would improve significantly with application of an $\mathrm{H}_{2}$ fuel cell type road transportation sector $\left(\mathrm{H}_{2}-\mathrm{FC}\right.$ scenarios). Primary gaseous $\left(\mathrm{CO}, \mathrm{NO}_{\mathrm{x}}\right)$ and particulate (soot) pollutants are mitigated as fossil fuel combustion process is replace with $\mathrm{H}_{2}$ oxidization process which only generate $\mathrm{H}_{2} \mathrm{O}$. Ozone, a major secondary pollution gas now still often found exceeding air quality standard in some U.S. regions, would be reduced to a significant extent since its precursors, $\mathrm{CO}, \mathrm{NO}_{\mathrm{x}}$ and $\mathrm{VOC}$ emissions are mitigated. Meanwhile, secondary aerosols, including sulfate aerosols and secondary organic aerosols, would also be reduced.

Air quality would also improve with application of an $\mathrm{H}_{2}$ internal combustion engine type road transportation sector $\left(\mathrm{H}_{2}\right.$-ICE scenarios). Emissions of primary gaseous and particulate pollutants ( $\mathrm{CO}$ and soot) are mitigated. Ambient ozone concentrations would decrease slightly as its precursors (CO and VOC) emissions by fossil fuel combustion from road transportation sector is eliminated. Ozone mitigation in the $\mathrm{H}_{2}-$ ICE scenarios is especially effective in VOC limited regions. Sulfate aerosols and secondary organic aerosols would also be reduced.

In conclusion, by using a comprehensive atmospheric chemistry-transport model that represents key physical and chemical mechanisms of the atmosphere, we show that transitioning to an $\mathrm{H}_{2}$-based road transportation sector would be beneficial in reducing concerns about air quality. 


\section{References}

1. Bond, T.C. and R.W. Bergstrom, Light absorption by carbonaceous particles: An investigative review, Aerosol Science and Technology, Volume 40, Issue 1, pp.27-67, 2006.

2. Conrad, R., and W. Seiler, Influence of Temperature, Moisture, and Organic Carbon on the Flux of H2 and CO Between Soil and Atmosphere: Field Studies in Subtropical Regions, J. Geophys. Res., 90(D3), 5699-5709, 1985.

3. Dockery, D.W., C.A. Pope, X.P. Xu, J.D. Spengler, J.H. Ware, M.E. Fay, B.G. Ferris, F.E. Speizer, An Association between Air-Pollution and Mortality in 6 United-States Cities, New England Journal of Medicine, Volume 329, Issue 24, pp. 1753-1759, 1993.

4. Heald, C. L., D. K. Henze, L. W. Horowitz, J. Feddema, J.-F. Lamarque, A. Guenther, P. G. Hess, F. Vitt, J. H. Seinfeld, A. H. Goldstein, and I. Fung, Predicted change in global secondary organic aerosol concentrations in response to future climate, emissions, and land use change, J. Geophys. Res., 113, D05211, doi:10.1029/2007JD009092, 2008.

5. Hoor, P., The impact of traffic emissions on atmospheric ozone and $\mathrm{OH}$ : results from QUANTIFY, Atmos. Chem. Phys., 9, 3113-3136, 2009.

6. Horowitz, L. W., et al., A global simulation of tropospheric ozone and related tracers: Description and evaluation of MOZART, version 2, J. Geophys. Res., 108(D24), 4784, doi:10.1029/2002JD002853, 2003.

7. IPCC, Special Report on Emissions Scenarios. Working Group III, IPCC, Cambridge University Press, Cambridge, 2000.

8. IPCC, Climate Change 2001, The Scientific Basis. Contribution of Working Group 1 to the Third Assessment Report of the IPCC, Cambridge University Press, New York, 2001.

9. Jacobson, M. Z., W. G. Colella, and D. M. Golden, Cleaning the air and improving health with hydrogen fuel-cell vehicles. Science, 308, 1901-1905, 2005. 
10. Jacobson, M.Z., Effects of wind-powered hydrogen fuel cell vehicles on stratospheric ozone and global climate, Geophys. Res. Lett., Vol.35, L19803, 2008 .

11. Lamarque, J.-F., J. T. Kiehl, P. G. Hess, W. D. Collins, L. K. Emmons, P. Ginoux, C. Luo, and X. X. Tie, Response of a coupled chemistry-climate model to changes in aerosol emissions: Global impact on the hydrological cycle and the tropospheric burdens of $\mathrm{OH}$, ozone, and $\mathrm{NO}_{\mathrm{x}}$, Geophys. Res. Lett., 32, L16809, doi:10.1029/2005GL023419, 2005.

12. Liebl. K.H., and W. Seiler. $\mathrm{CO}$ and $\mathrm{H}_{2}$ destruction at the soil surface, in Microbial Production and Utilization of Gases, edited by H.G. Schlegel, G. Gottschalk, and N. Pfenning, Goltze, Gottingen, Germany, pp. 215-229, 1976.

13. Matthes, S., V. Grewe, R. Sausen, and G.-J. Roelofs, Global impact of road traffic emissions on tropospheric ozone, Atmos. Chem. Phys., 7, 1707-1718, 2007.

14. Niemeier, U., C. Granier, L. Kornblueh, S. Walters, and G. P. Brasseur (2006), Global impact of road traffic on atmospheric chemical composition and on ozone climate forcing, J. Geophys. Res., 111, D09301, doi:10.1029/2005JD006407.

15. Pfister, G. G., P. G. Hess, L. K. Emmons, P. J. Rasch, and F. M. Vitt (2008), Impact of the summer 2004 Alaska fires on top of the atmosphere clear-sky radiation fluxes, J. Geophys. Res., 113, D02204, doi:10.1029/2007JD008797.

16. Schultz, M., T. Diehl, G. Brasseur, and W. Zittel, Air pollution and climateforcing impacts of a global hydrogen economy. Science, 302, 624-627, 2003.

17. Warwick, N. J., S. Bekki, E. G. Nisbet, and J. A. Pyle, Impact of a hydrogen economy on the stratosphere and troposphere studied in a 2-D model.

Geophys. Res. Lett., 31, doi:10.1029/2003GL019224, 2004.

18. Yonemura, S. et al., Continuous measurements of $\mathrm{CO}$ and $\mathrm{H} 2$ deposition velocities onto an andisol: uptake control by soil moisture, Tellus, Volume 51 Issue 3, Pages 688 - 700, 1999. 
19. Yonemura, S., S. Kawashima, and H. Tsuruta, Carbon monoxide, hydrogen, and methane uptake by soils in a temperate arable field and a forest, $J$.

Geophys. Res., 105(D11), 14,347-14,362, 2000. 


\section{Tables and figures}

Table 1. Tropospheric burdens and changes of relevant species in A1FI.

\begin{tabular}{ccccc}
\hline & A1FI-BL & A1FI-BL+H & A1FI-H ${ }_{2}-\mathrm{FC}$ & A1FI- ${ }_{2}-$ ICE \\
\hline $\mathrm{H}_{2}$ & $839 \mathrm{ppb}$ & $41 \%$ & $40 \%$ & $38 \%$ \\
$\mathrm{O}_{3}$ & $44 \mathrm{ppb}$ & $0 \%$ & $-7 \%$ & $-1 \%$ \\
$\mathrm{OH}$ & $9.1 \times 10^{5} \mathrm{molecules} / \mathrm{cm}^{3}$ & $-2 \%$ & $-4 \%$ & $7 \%$ \\
$\mathrm{CO}$ & $133 \mathrm{ppb}$ & $1 \%$ & $-14 \%$ & $-18 \%$ \\
$\mathrm{NO}_{\mathrm{x}}$ & $100 \mathrm{ppt}$ & $0 \%$ & $-16 \%$ & $10 \%$ \\
soot & $0.01 \mu \mathrm{g} / \mathrm{m}^{3}$ & $0 \%$ & $-17 \%$ & $-17 \%$ \\
$\mathrm{SO}_{4}$ & $0.34 \mu \mathrm{g} / \mathrm{m}^{3}$ & $0 \%$ & $-4 \%$ & $-3 \%$ \\
$\mathrm{SOA}^{3}$ & $0.04 \mu \mathrm{g} / \mathrm{m}^{3}$ & $0 \%$ & $-12 \%$ & $-18 \%$ \\
$\mathrm{PAN}$ & $197 \mathrm{ppt}$ & $0 \%$ & $-23 \%$ & $-14 \%$ \\
$\mathrm{NMV}$ & $9.9 \mathrm{ppb}$ & $1 \%$ & $-11 \%$ & $-18 \%$ \\
ISOP & $41.0 \mathrm{ppt}$ & $0 \%$ & $24 \%$ & $-1 \%$ \\
\hline
\end{tabular}


Table 2. Tropospheric burdens and changes of relevant species in B1.

\begin{tabular}{ccccc}
\hline & $\mathrm{B} 1-\mathrm{BL}$ & $\mathrm{B} 1-\mathrm{BL}+\mathrm{H}_{2}$ & $\mathrm{~B} 1-\mathrm{H}_{2}-\mathrm{FC}$ & $\mathrm{B}^{-}-\mathrm{H}_{2}-\mathrm{ICE}$ \\
\hline $\mathrm{H}_{2}$ & $621 \mathrm{ppb}$ & $20 \%$ & $20 \%$ & $19 \%$ \\
$\mathrm{O}_{3}$ & $37 \mathrm{ppb}$ & $0 \%$ & $-5 \%$ & $-1 \%$ \\
$\mathrm{OH}$ & $10.1 \times 10^{5}$ molecules $/ \mathrm{cm}^{3}$ & $-1 \%$ & $-4 \%$ & $3 \%$ \\
$\mathrm{CO}$ & $90 \mathrm{ppb}$ & $0 \%$ & $-4 \%$ & $-7 \%$ \\
$\mathrm{NO}_{\mathrm{x}}$ & $60 \mathrm{ppt}$ & $0 \%$ & $-11 \%$ & $3 \%$ \\
soot & $0.01 \mu \mathrm{g} / \mathrm{m}^{3}$ & $0 \%$ & $-7 \%$ & $-7 \%$ \\
$\mathrm{SO}_{4}$ & $0.33 \mu \mathrm{g} / \mathrm{m}^{3}$ & $0 \%$ & $-4 \%$ & $-3 \%$ \\
$\mathrm{SOA}^{3}$ & $0.03 \mu \mathrm{g} / \mathrm{m}^{3}$ & $0 \%$ & $-3 \%$ & $-9 \%$ \\
$\mathrm{PAN}$ & $110 \mathrm{ppt}$ & $0 \%$ & $-16 \%$ & $-10 \%$ \\
$\mathrm{NMV}$ & $5.1 \mathrm{ppb}$ & $0 \%$ & $-7 \%$ & $-13 \%$ \\
ISOP & $47.7 \mathrm{ppt}$ & $0 \%$ & $19 \%$ & $0 \%$ \\
\hline
\end{tabular}




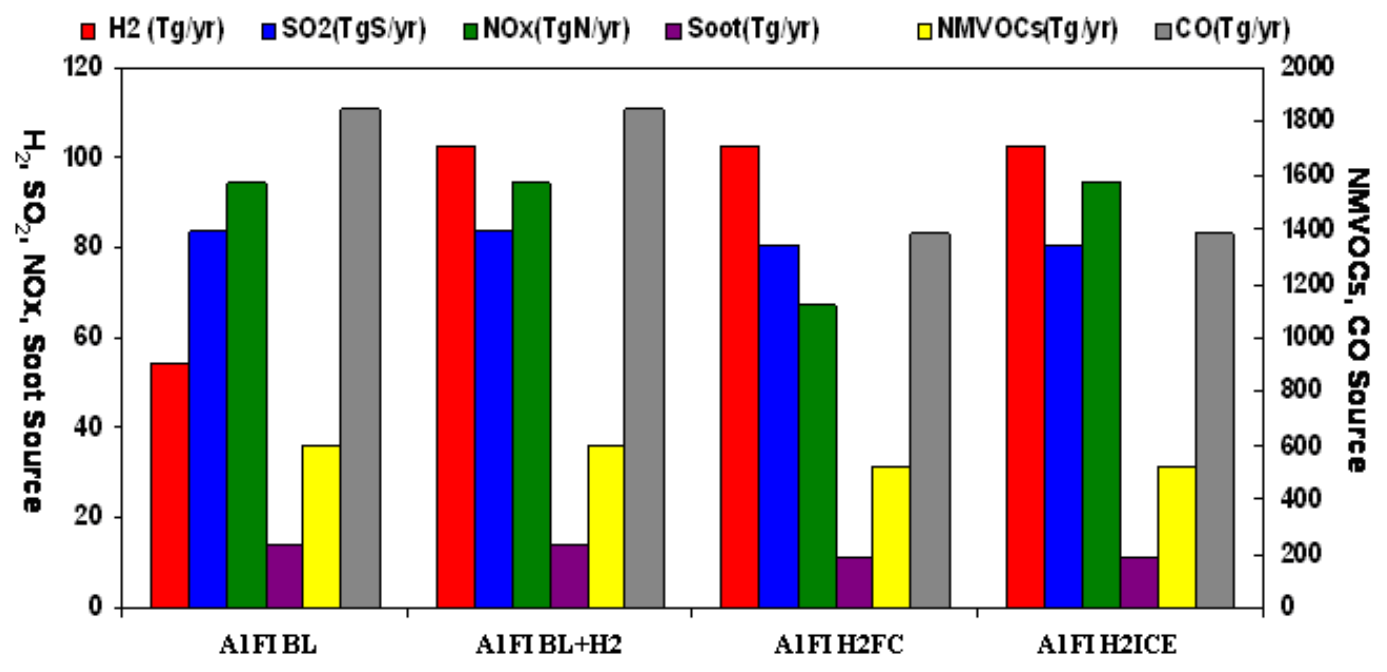

Figure 1. A1FI based total emission scenarios. 


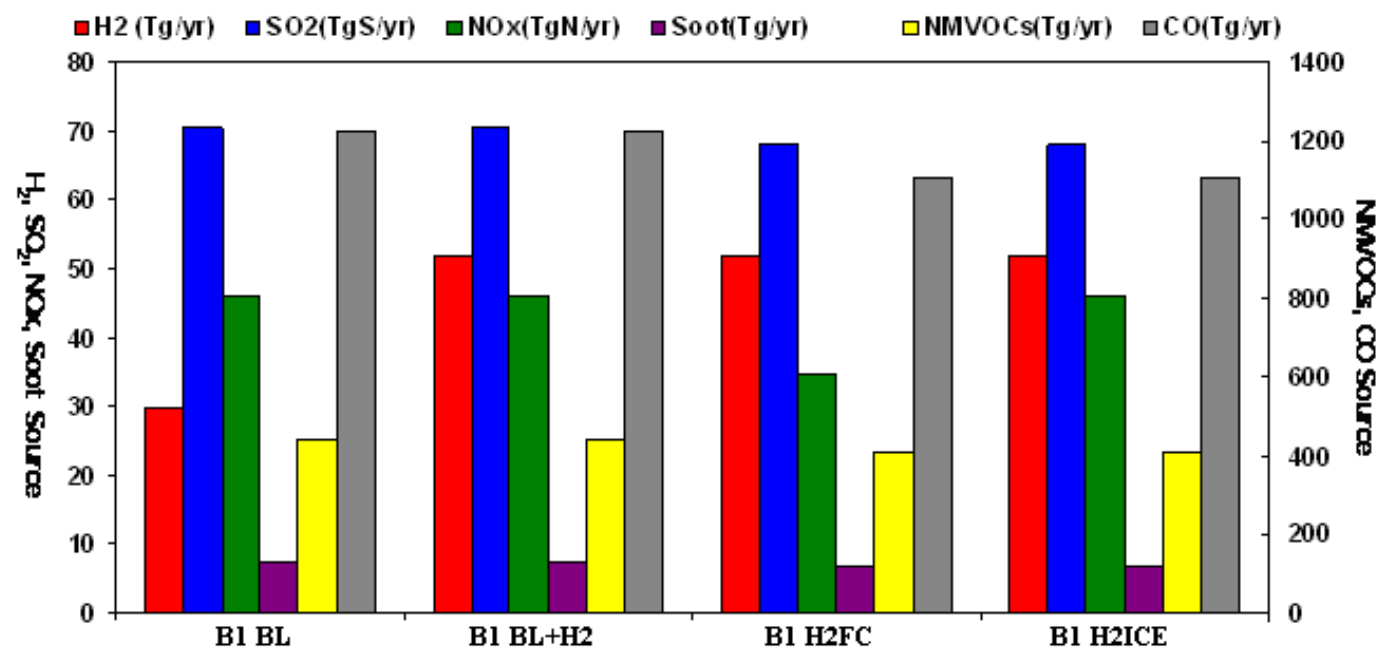

Figure 2. B1 based total emission scenarios. 

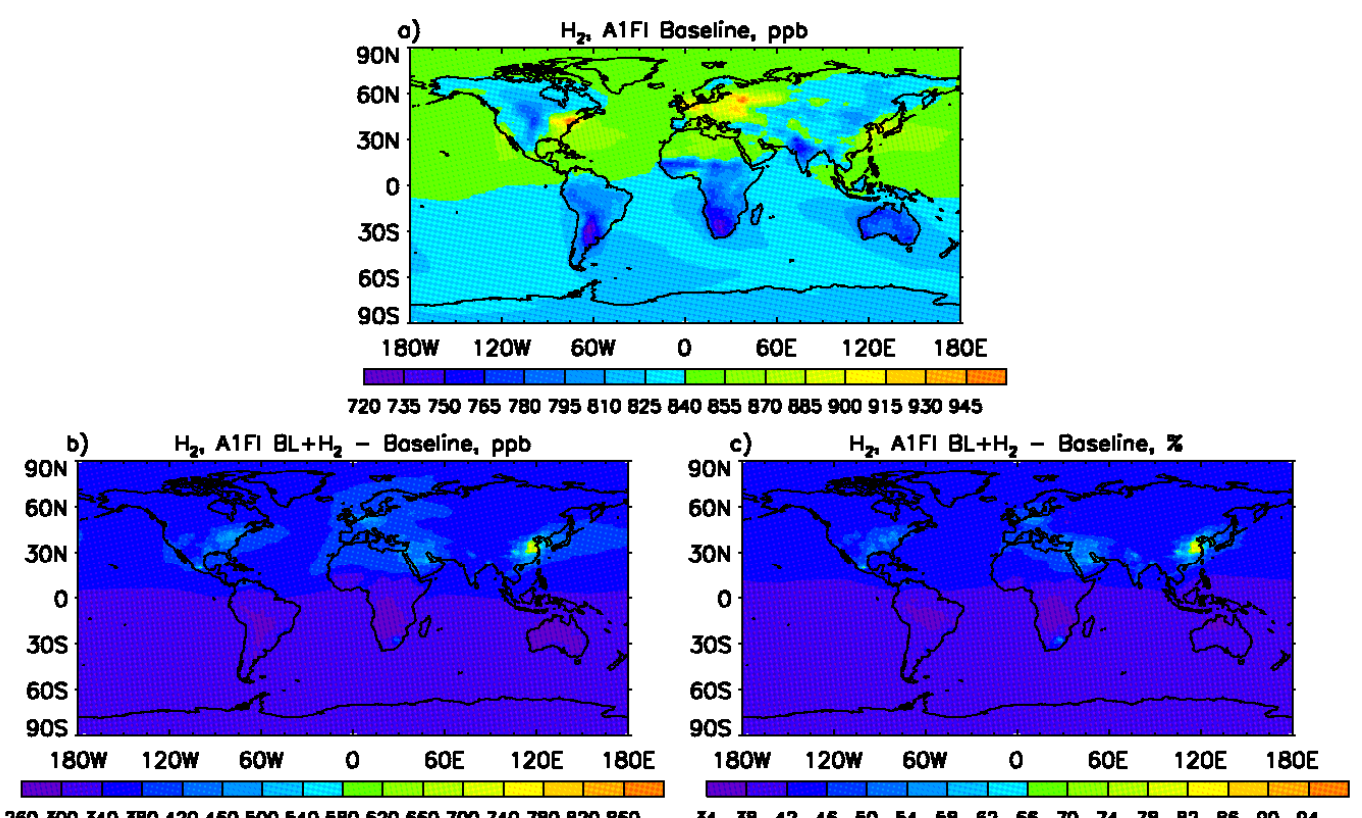

260300340380420460500540580620660700740780820860
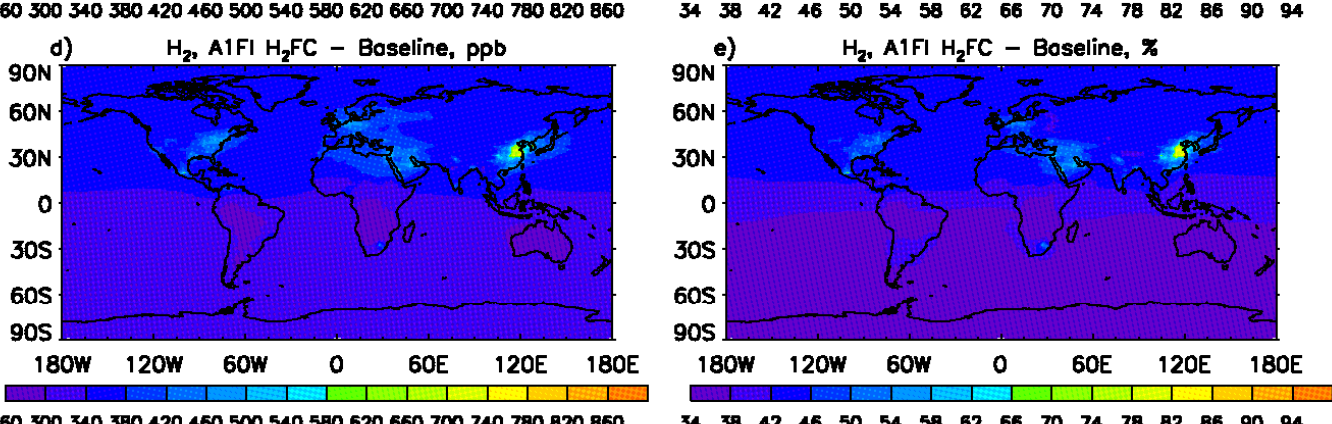

260300340380420460500540580620660700740780820860
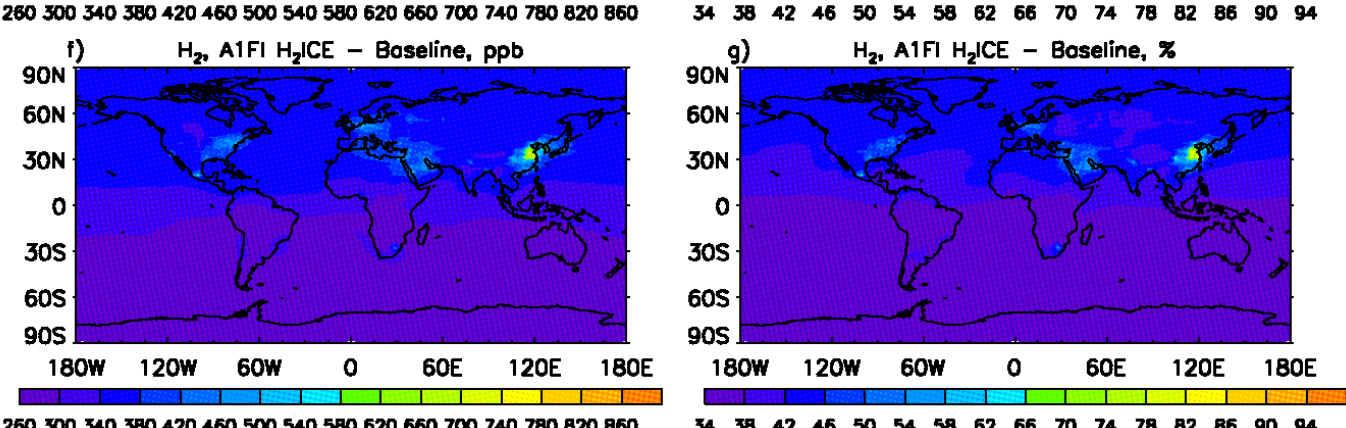

260300340380420460500540580620660700740780820860

$\begin{array}{llllllllllllllll}34 & 38 & 42 & 46 & 50 & 54 & 58 & 62 & 66 & 70 & 74 & 78 & 82 & 86 & 90 & 94\end{array}$

Figure 3. Change of annual-mean ground-level $\mathrm{H}_{2}$ mixing ratio between A1FI-BL and A1FI $\mathrm{H}_{2}$ scenarios. 

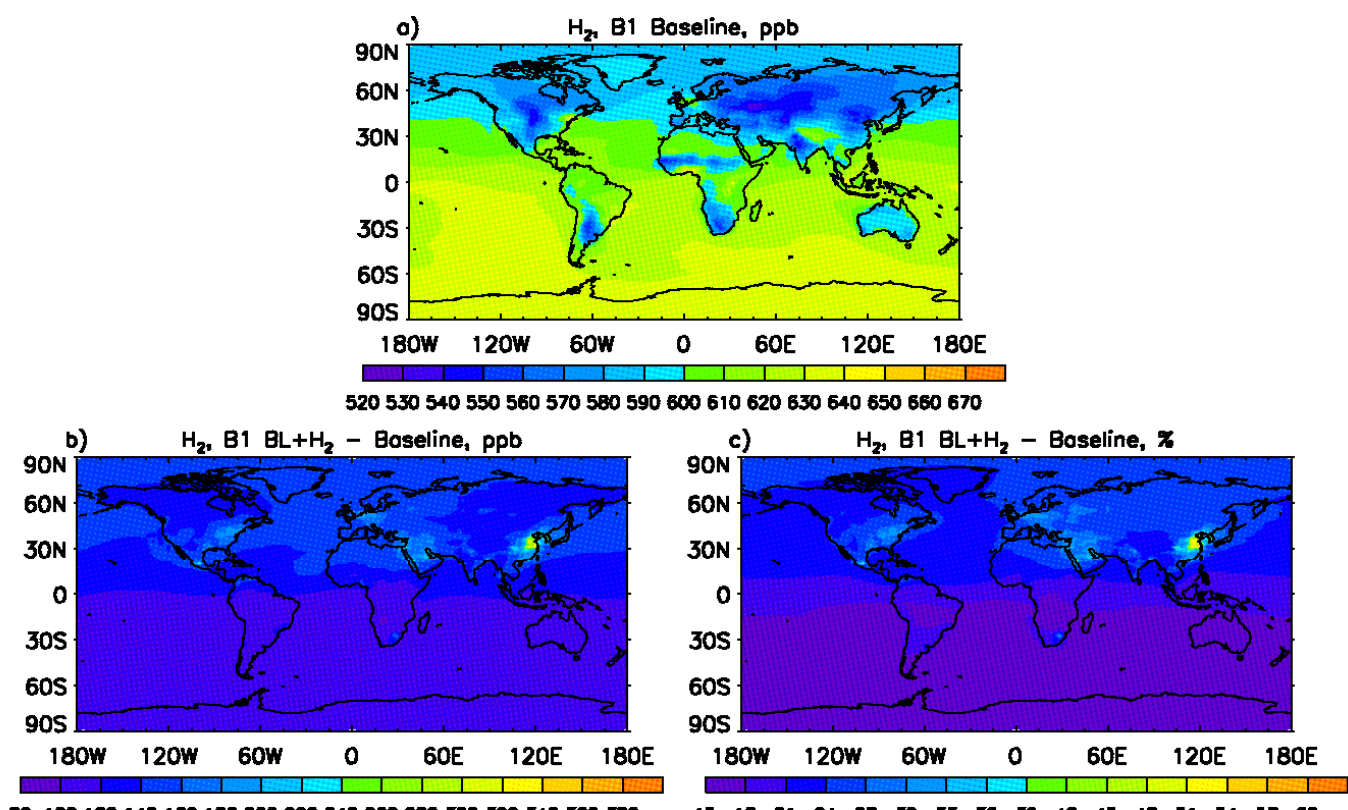

80100120140160180200220240260280300320340360380
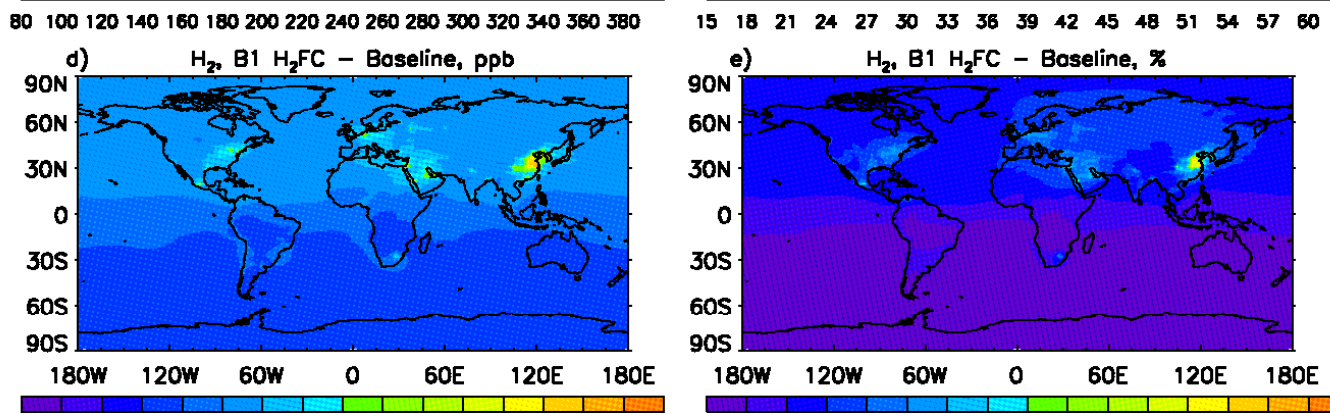

30507090110130150170190210230250270290310330
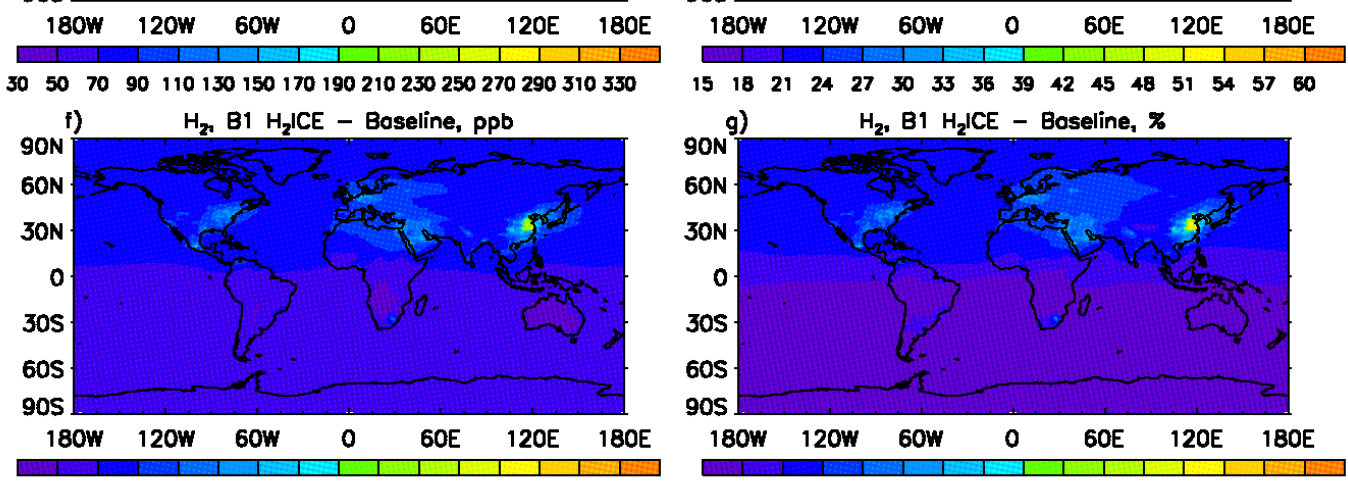

BO 100120140160180200220240260280300320340360380

$\begin{array}{llllllllllllllll}15 & 18 & 21 & 24 & 27 & 30 & 33 & 36 & 39 & 42 & 45 & 48 & 51 & 54 & 57 & 60\end{array}$

Figure 4. Similar to Figure 3 except that these figures are for the B1 scenarios. 

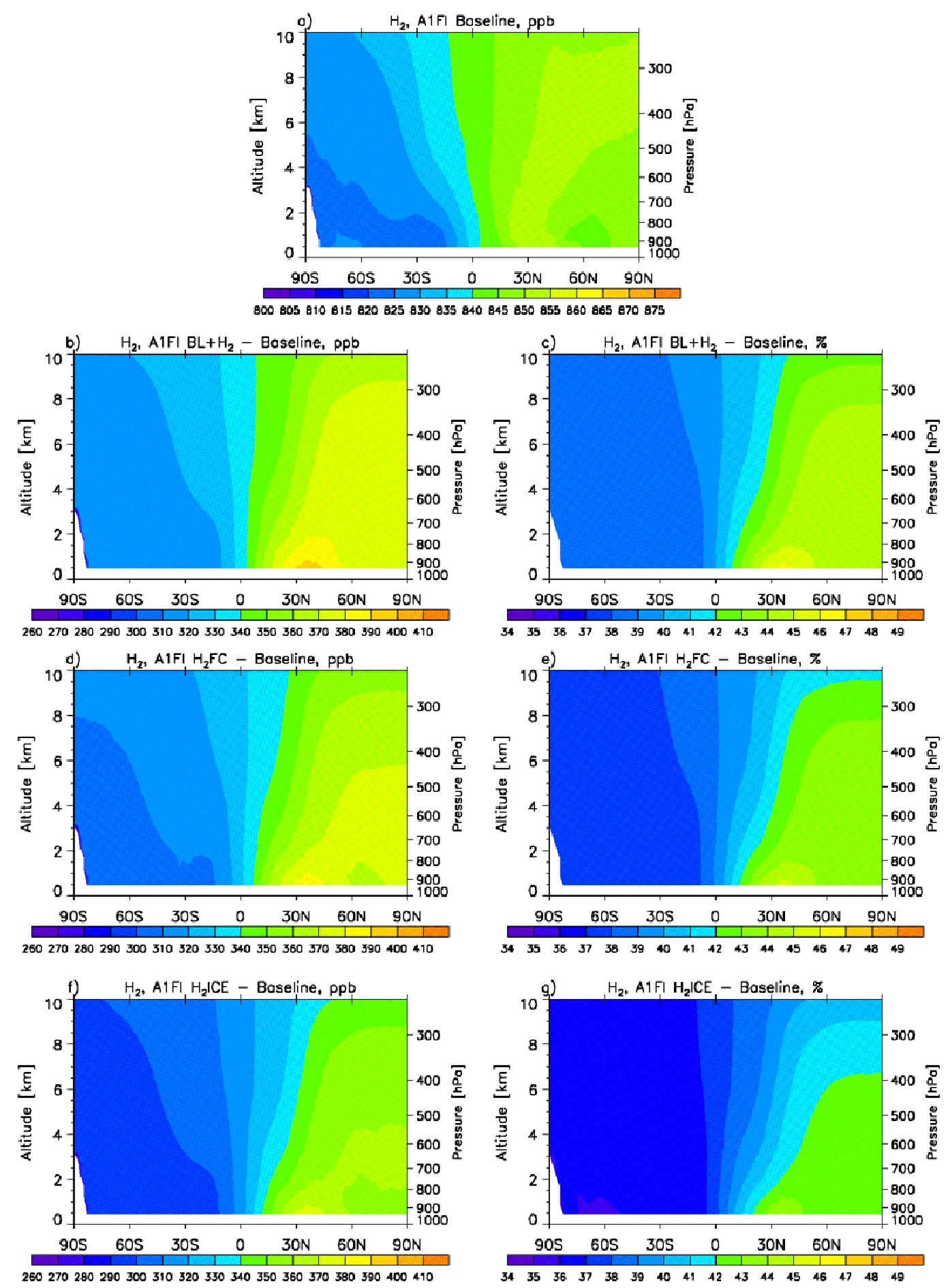

Figure 5. Change of annual, zonal mean $\mathrm{H}_{2}$ mixing ratio between A1FI-BL and A1FI $\mathrm{H}_{2}$ scenarios. 

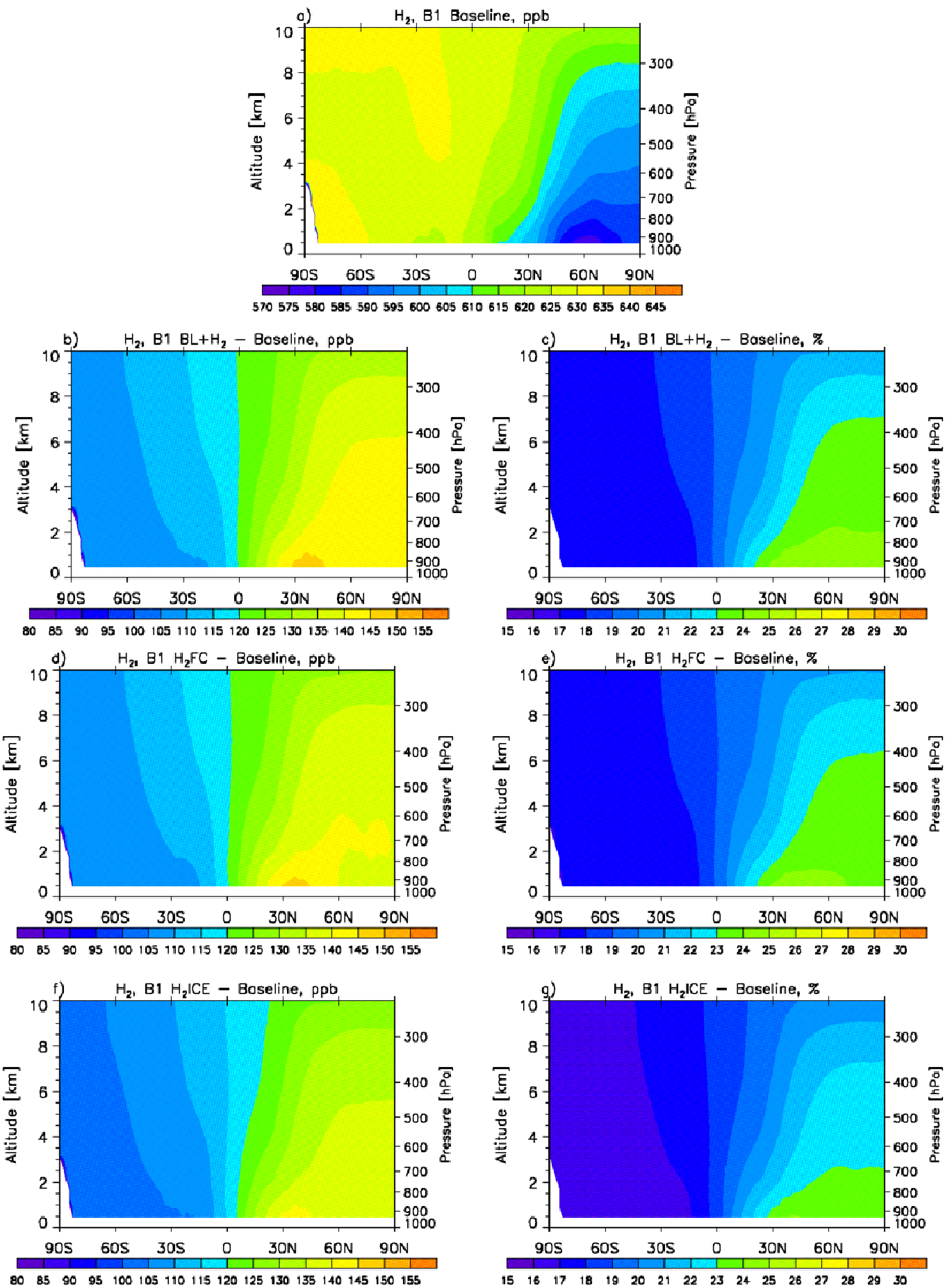

Figure 6. Similar to Figure 5 except that these figures are for the B1 scenarios. 

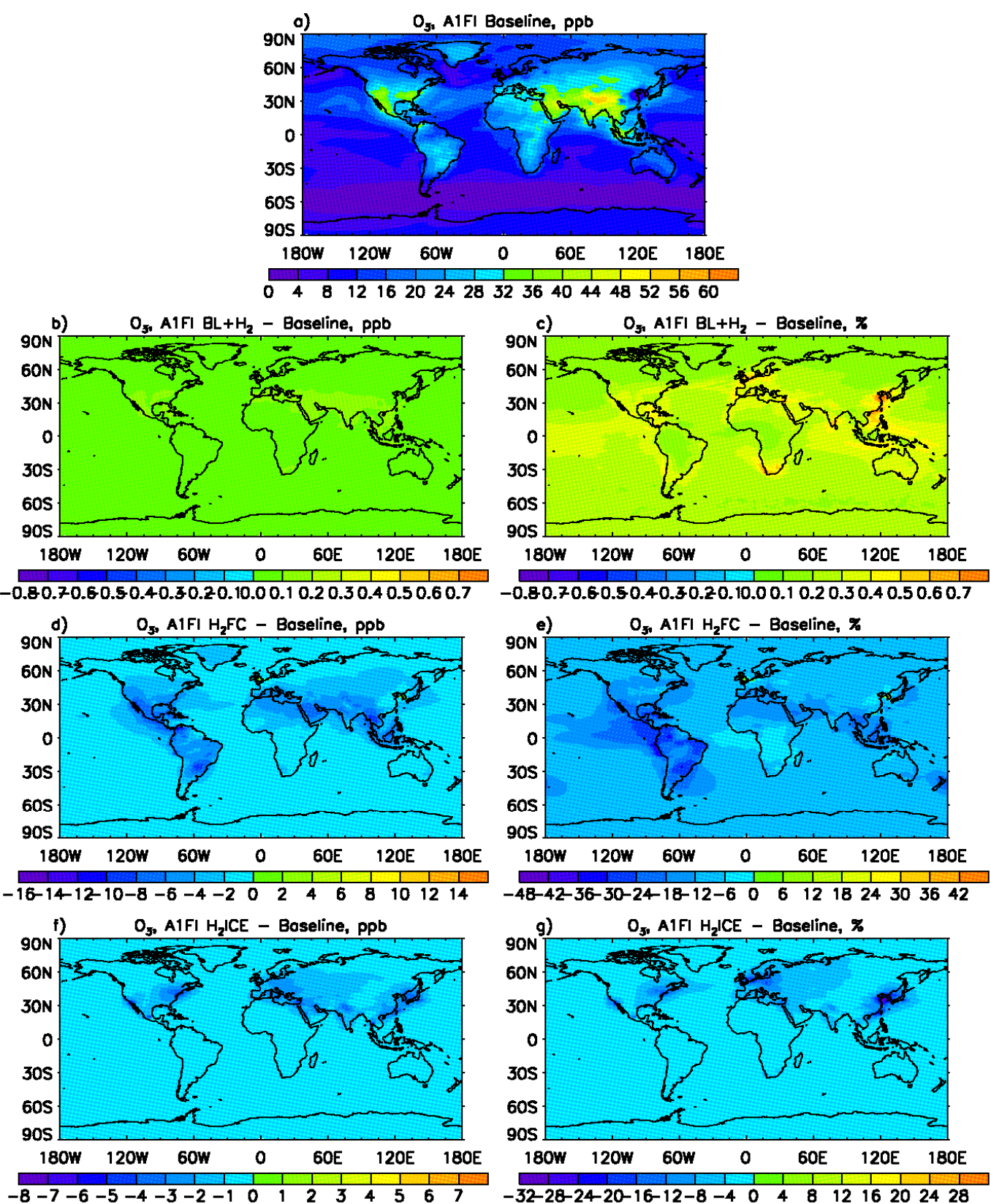

Figure 7. Change of annual-mean ground-level $\mathrm{O}_{3}$ mixing ratio between $\mathrm{A1FI-BL}$ and $\mathrm{A1FI} \mathrm{H}_{2}$ scenarios. 

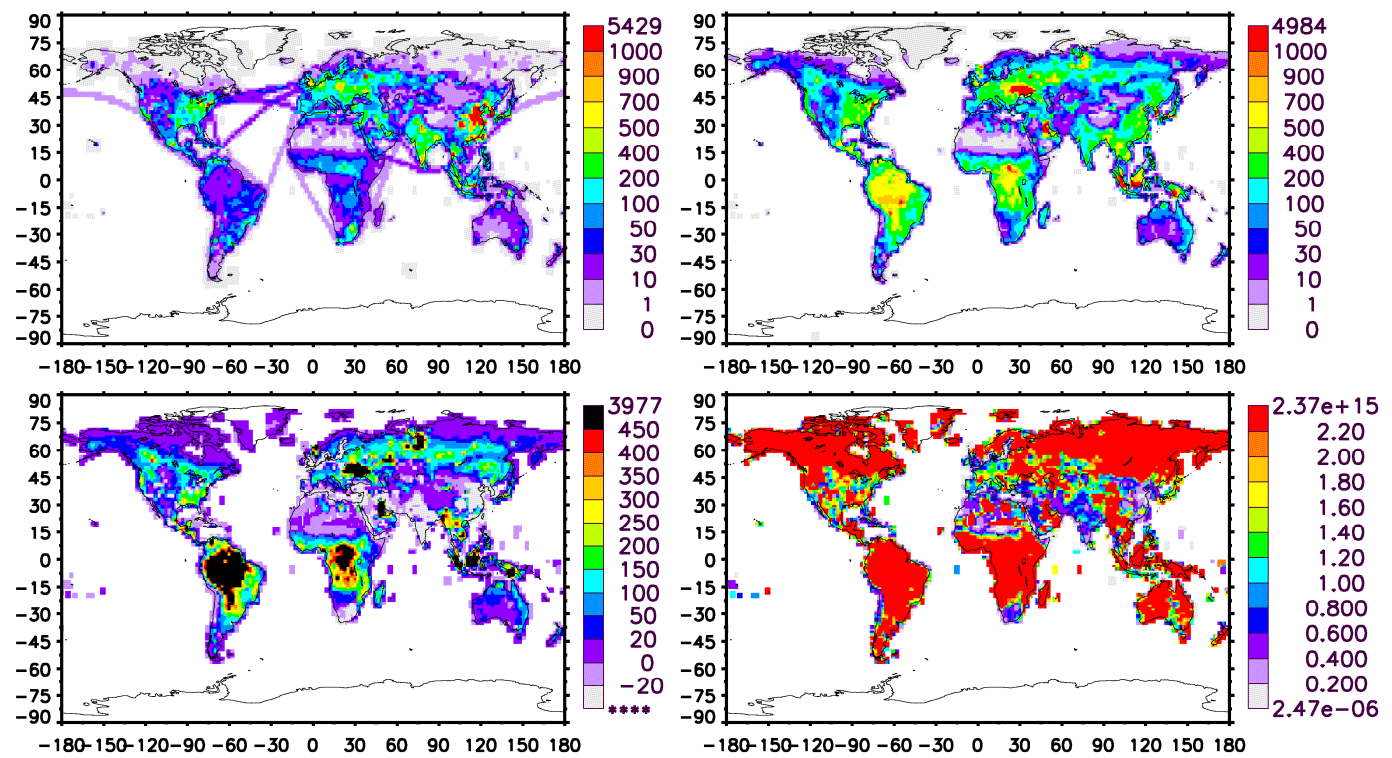

Figure 8. Annual mean emissions of NOx and $\operatorname{VOC}\left(10^{9}\right.$ molecules $\left.\mathrm{cm}^{-2} \mathrm{~s}^{-1}\right)$ in A1FI BL scenario. Upper left: NOx. Upper right: VOC. Lower left: VOC-NOx. Lower right: VOC/NOx. 


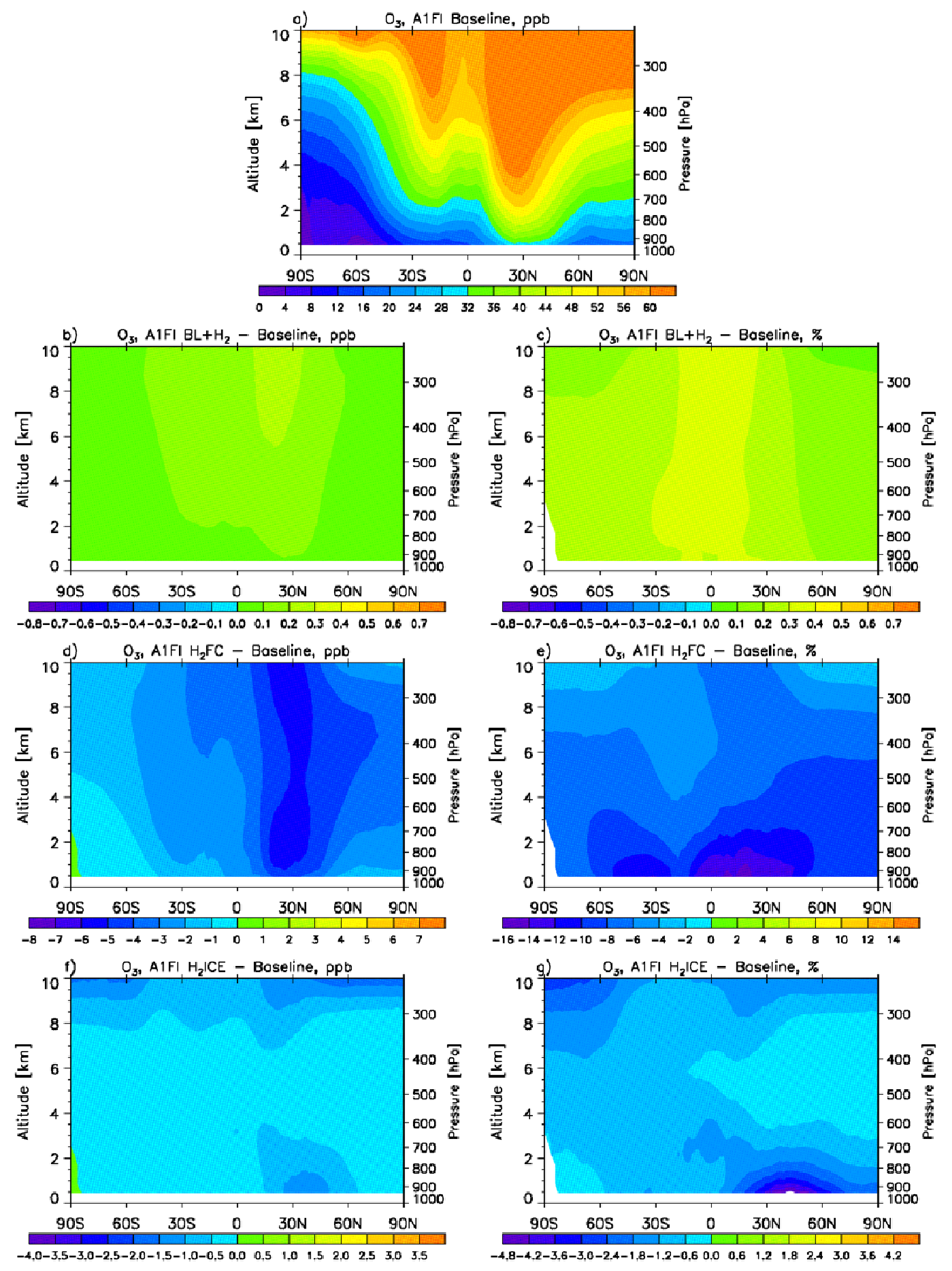

Figure 9. Change of annual, zonal mean $\mathrm{O}_{3}$ mixing ratio between A1FI-BL and A1FI $\mathrm{H}_{2}$ scenarios. 

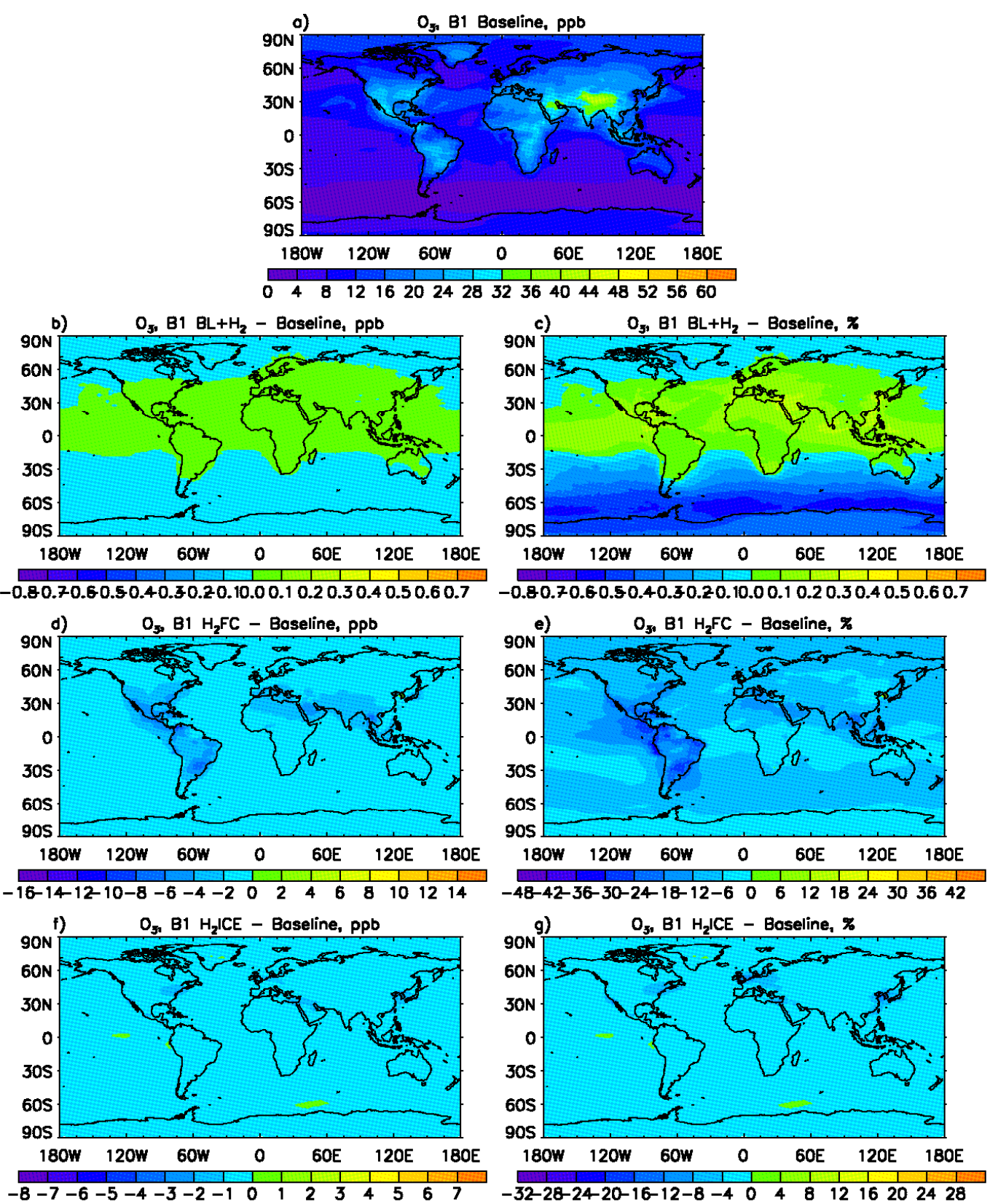

Figure 10. Similar to Figure 7 except that these figures are for the B1 scenarios. 


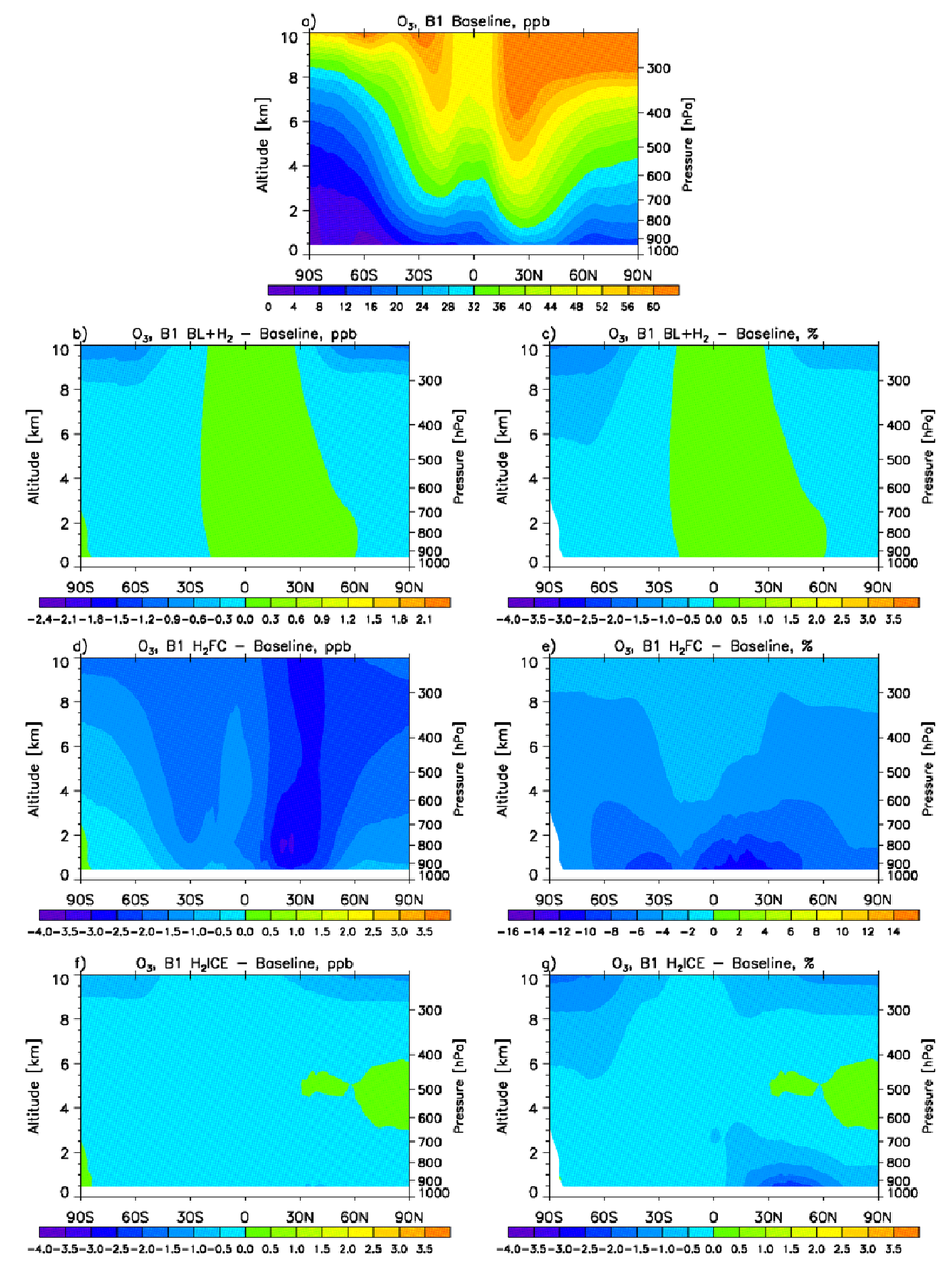

Figure 11. Similar to Figure 9 except that these figures are for the B1 scenarios. 


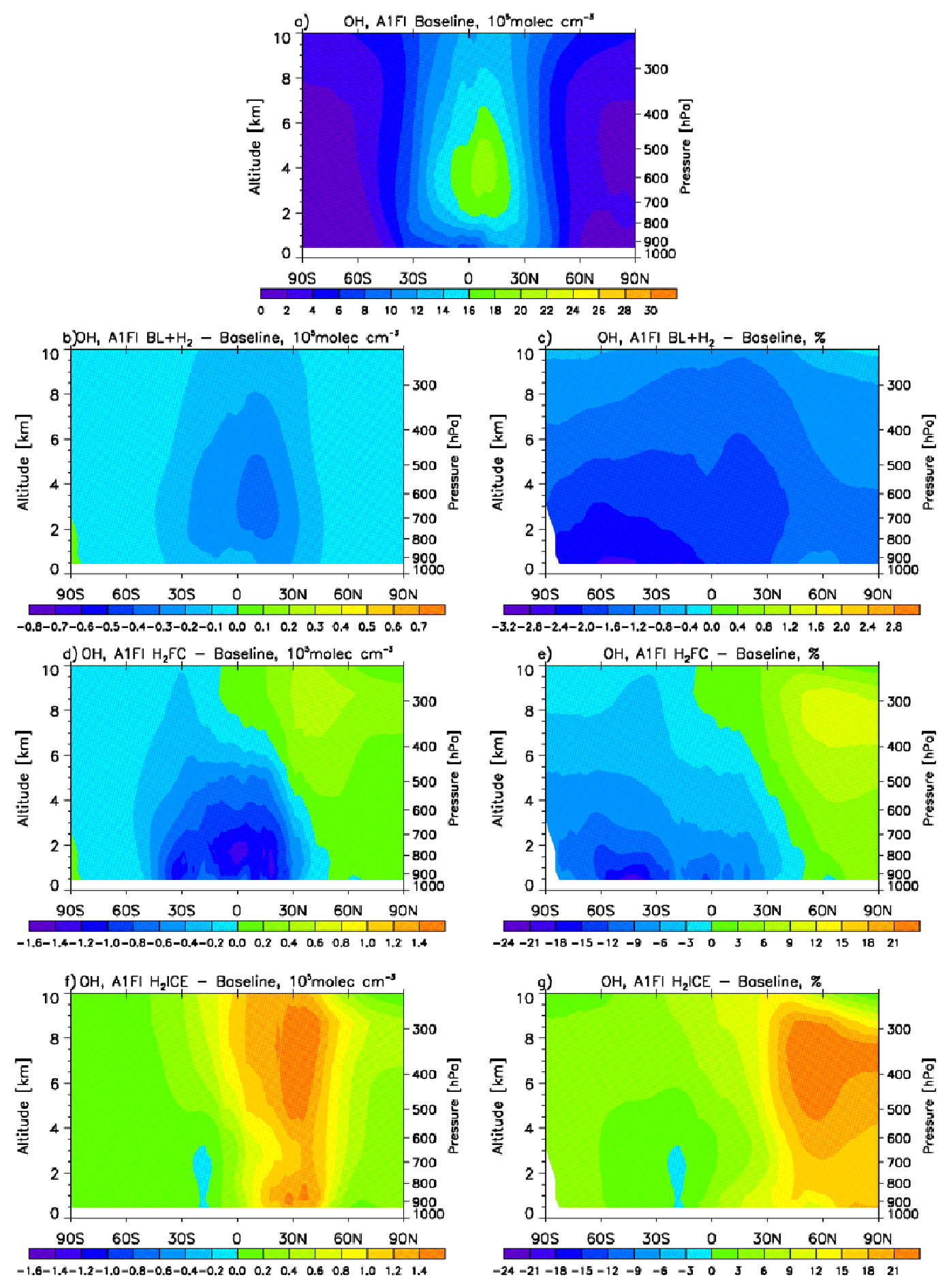

Figure 12. Change of annual, zonal mean $\mathrm{OH}$ concentration between A1FI-BL and A1FI $\mathrm{H}_{2}$ scenarios. 

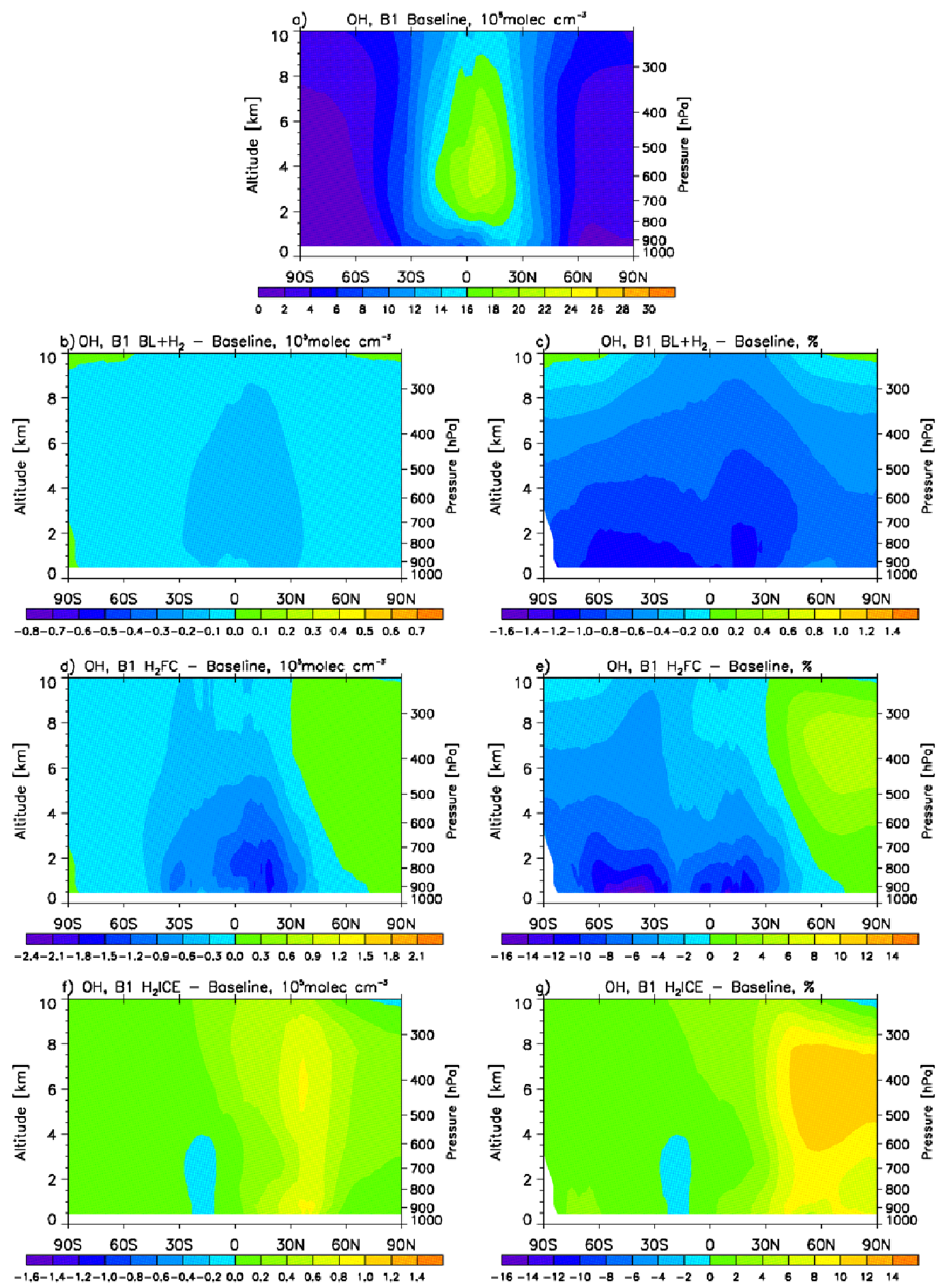

Figure 13. Similar to Figure 12 except that these figures are for the B1 scenarios. 

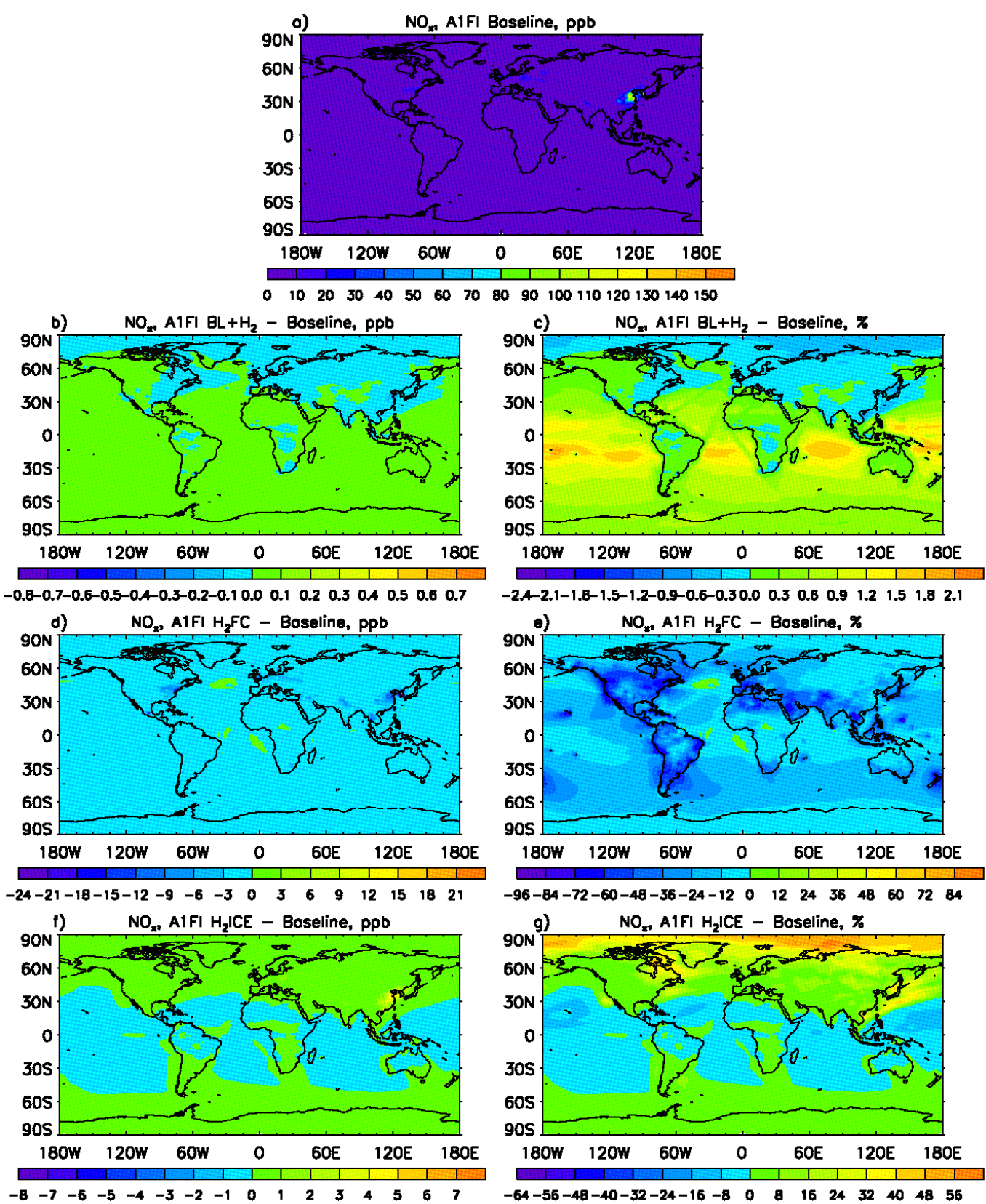

Figure 14. Change of annual mean ground level $\mathrm{NO}_{\mathrm{x}}$ mixing ratio between $\mathrm{A1FI}-\mathrm{BL}$ and $\mathrm{A1FI} \mathrm{H}_{2}$ scenarios. 

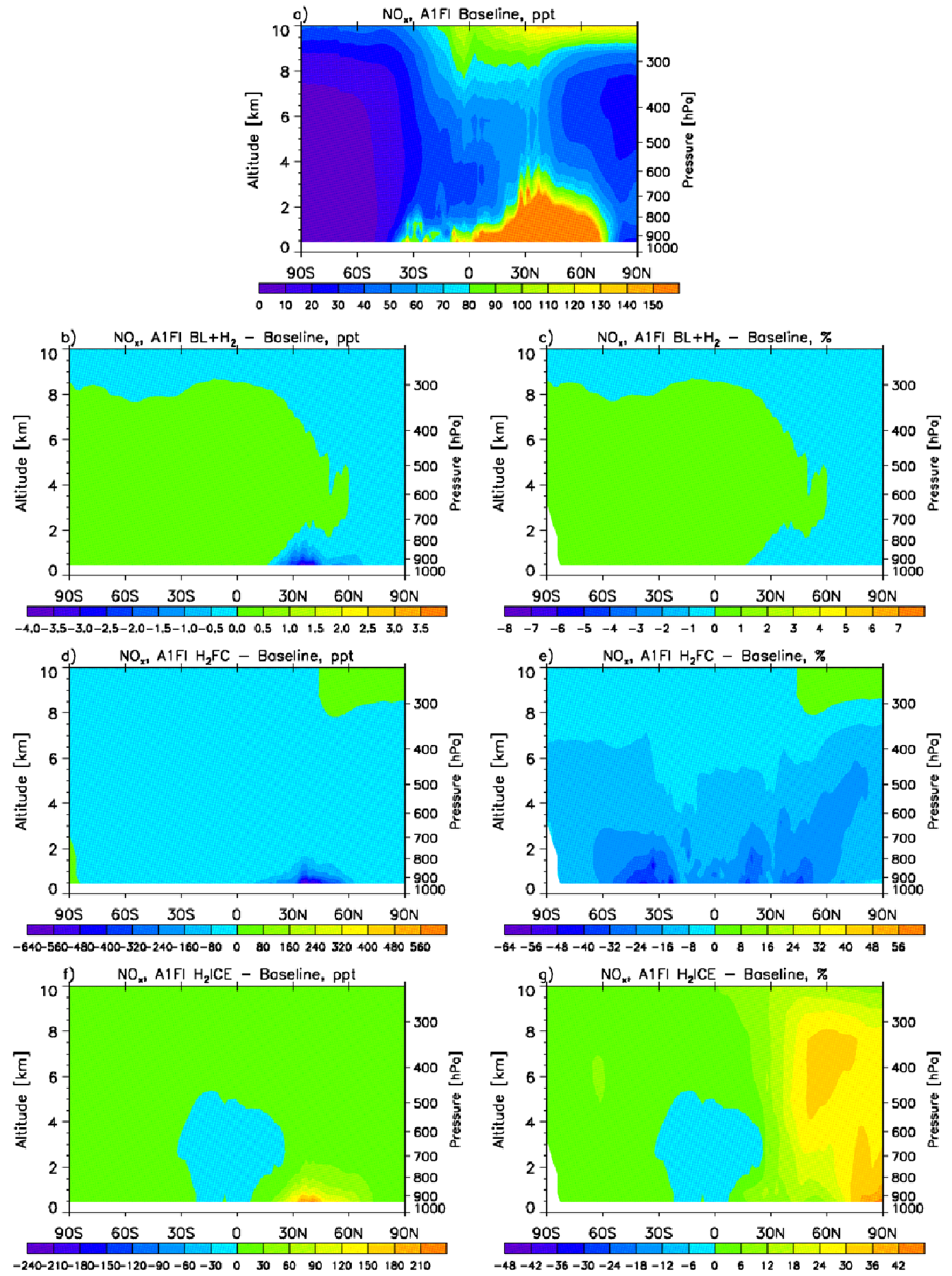

Figure 15. Change of annual, zonal mean $\mathrm{NO}_{\mathrm{x}}$ mixing ratio between A1FI-BL and A1FI $\mathrm{H}_{2}$ scenarios. 

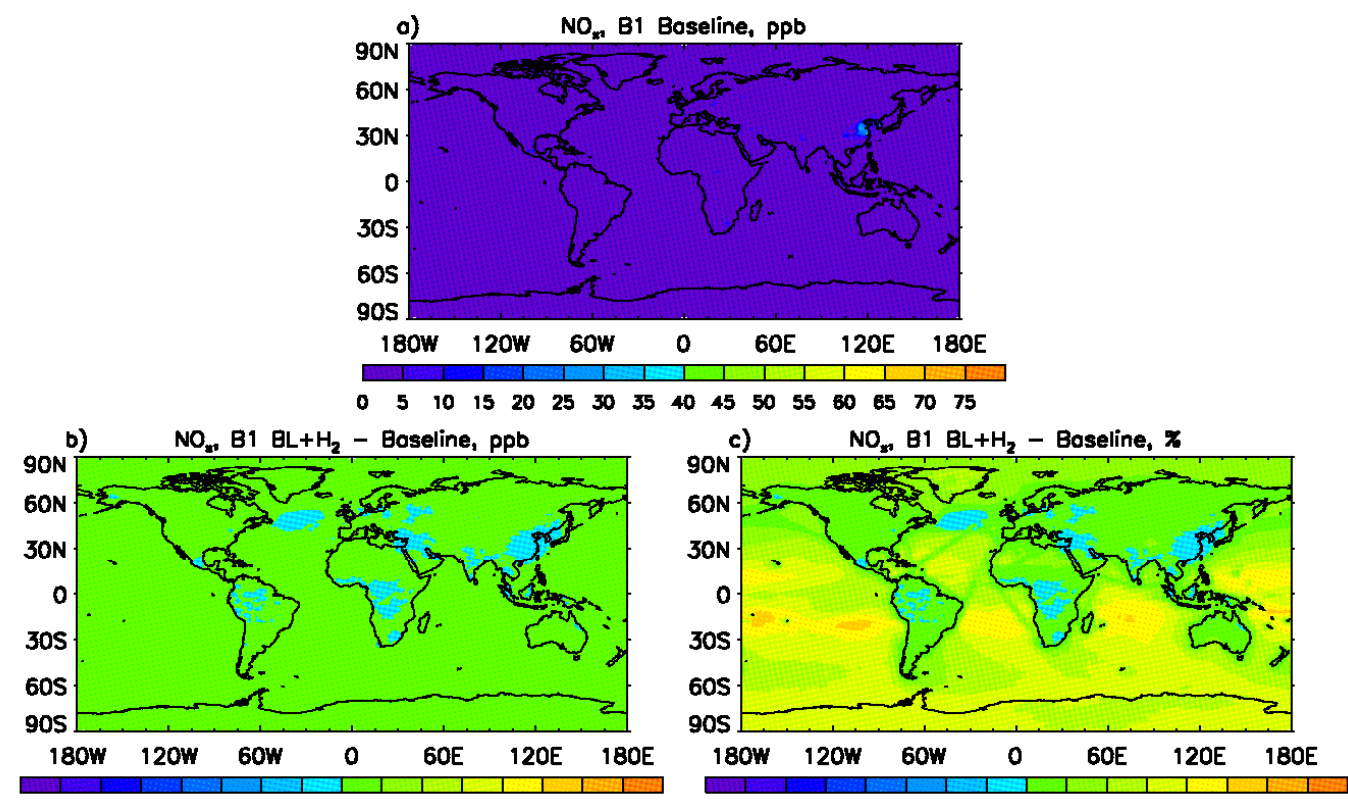

$\begin{array}{lllllllll}-0.8-0.7-0.6-0.5-0.4-0.3-0.2-0.1 & 0.0 & 0.1 & 0.2 & 0.3 & 0.4 & 0.5 & 0.6 & 0.7\end{array}$

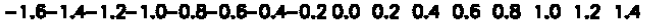
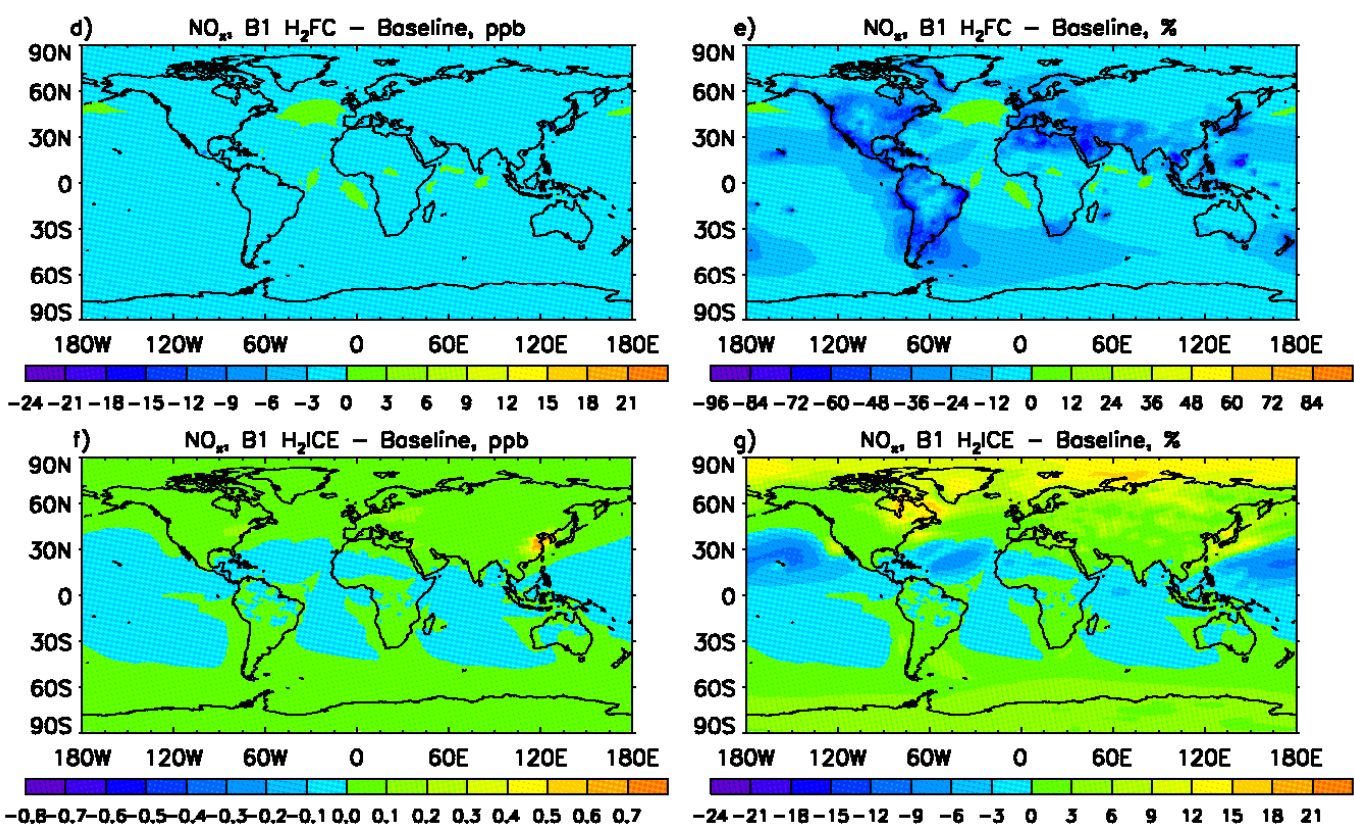

Figure 16. Similar to Figure 14 except that these figures are for the B1 scenarios. 

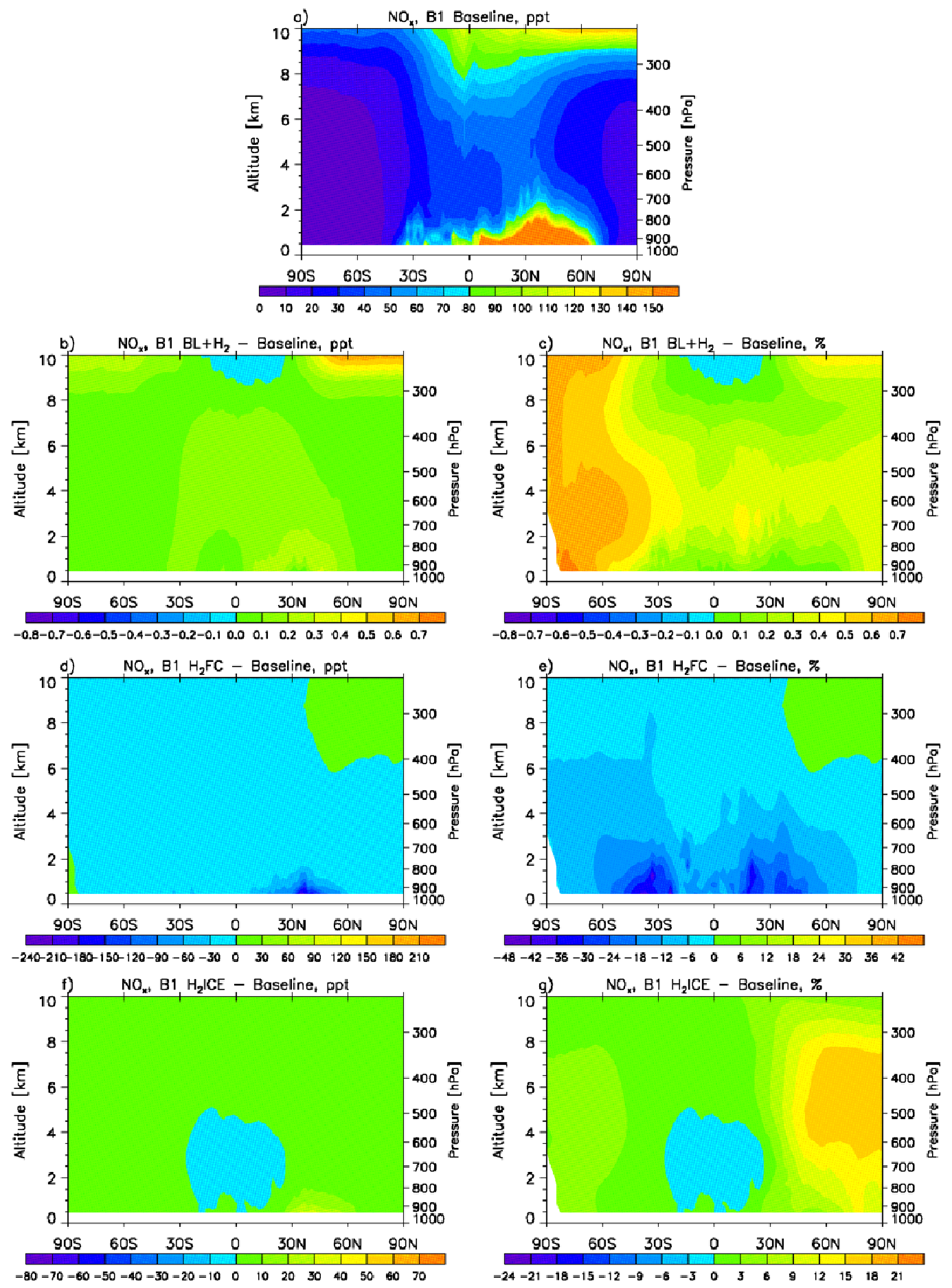

Figure 17. Similar to Figure 15 except that these figures are for the B1 scenarios. 

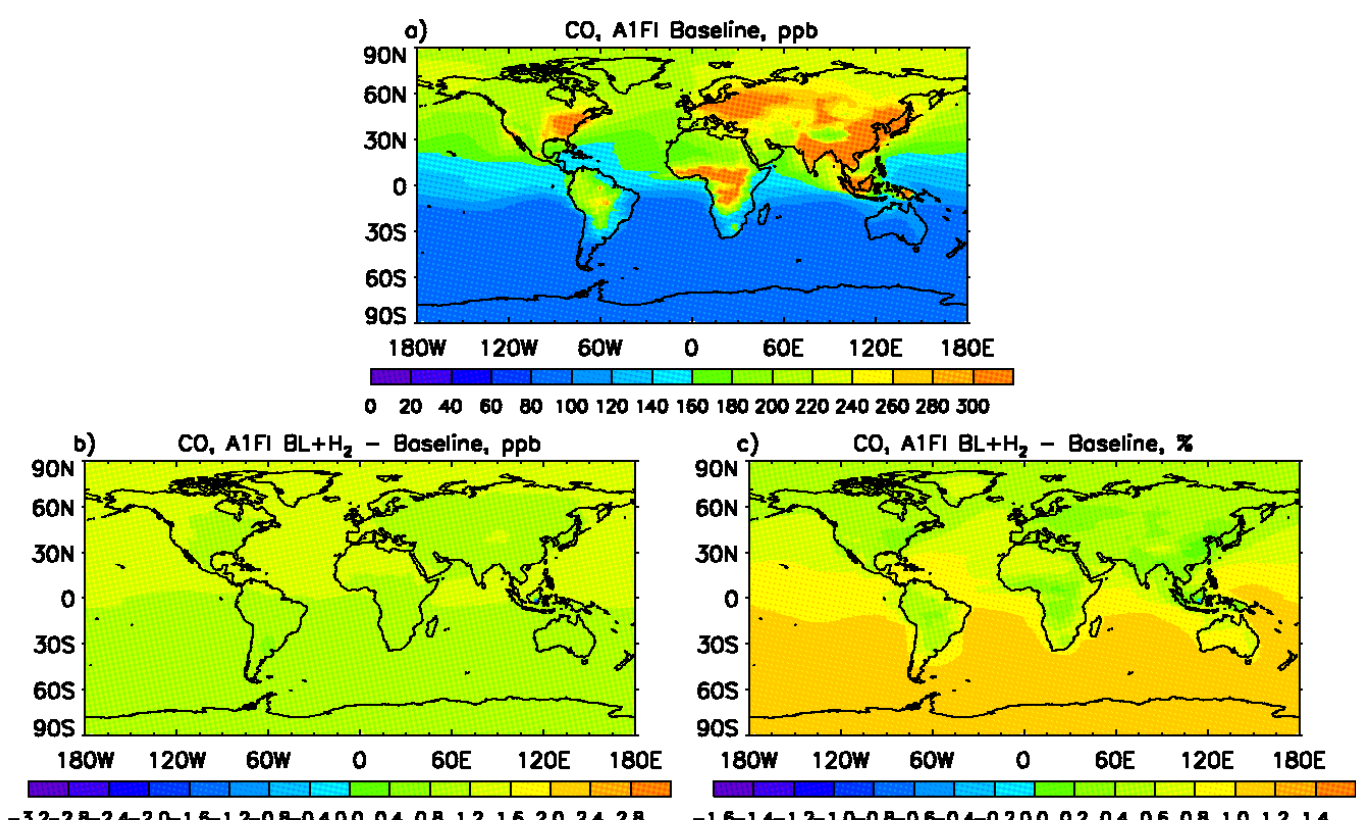

-3.2-2.8-2.4-2.0-1.6-1.2-0.8-0.4 $0.0 \quad 0.4 \quad 0.81 .2 \quad 1.62 .02 .42 .8$

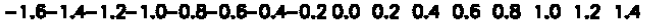
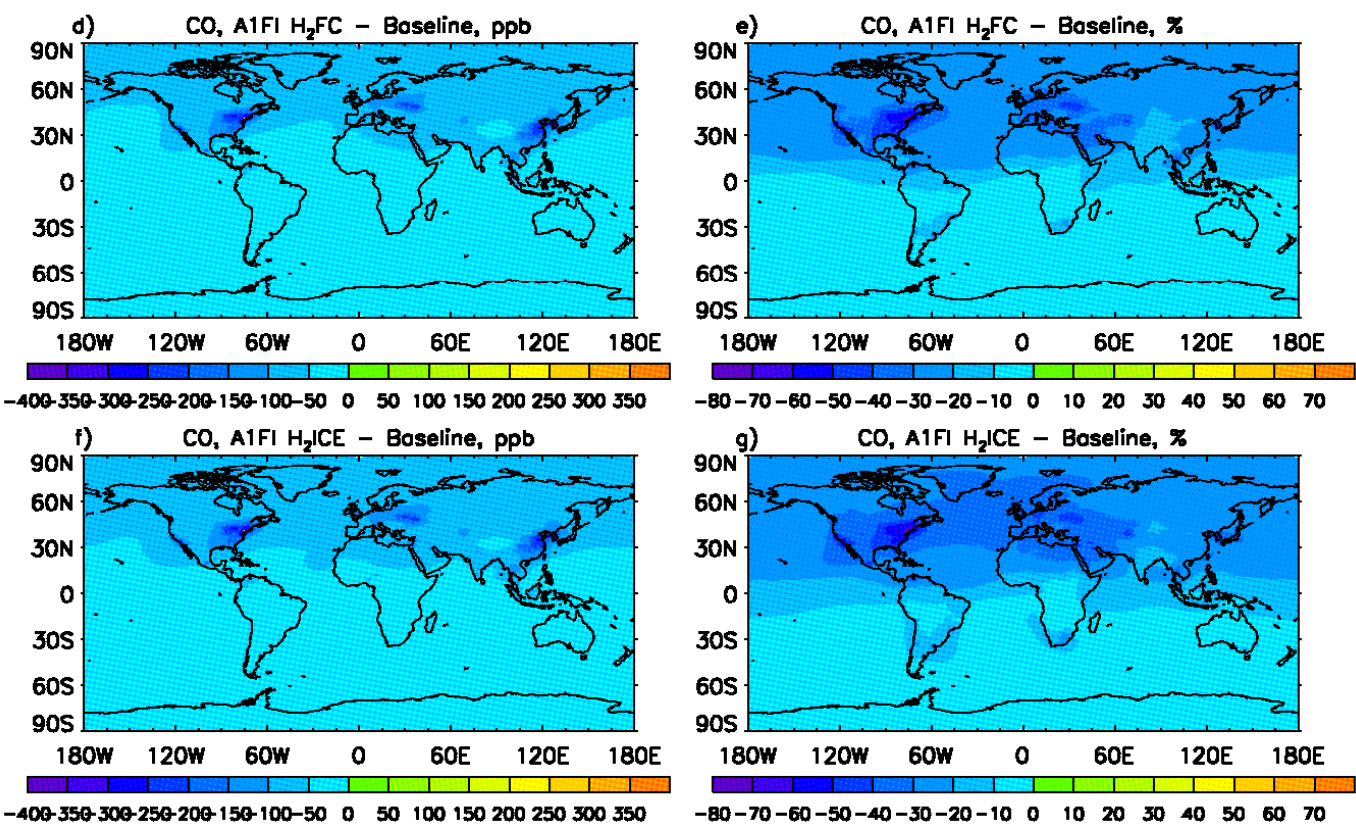

Figure 18. Change of annual mean ground level CO mixing ratio between A1FI-BL and A1FI $\mathrm{H}_{2}$ scenarios. 

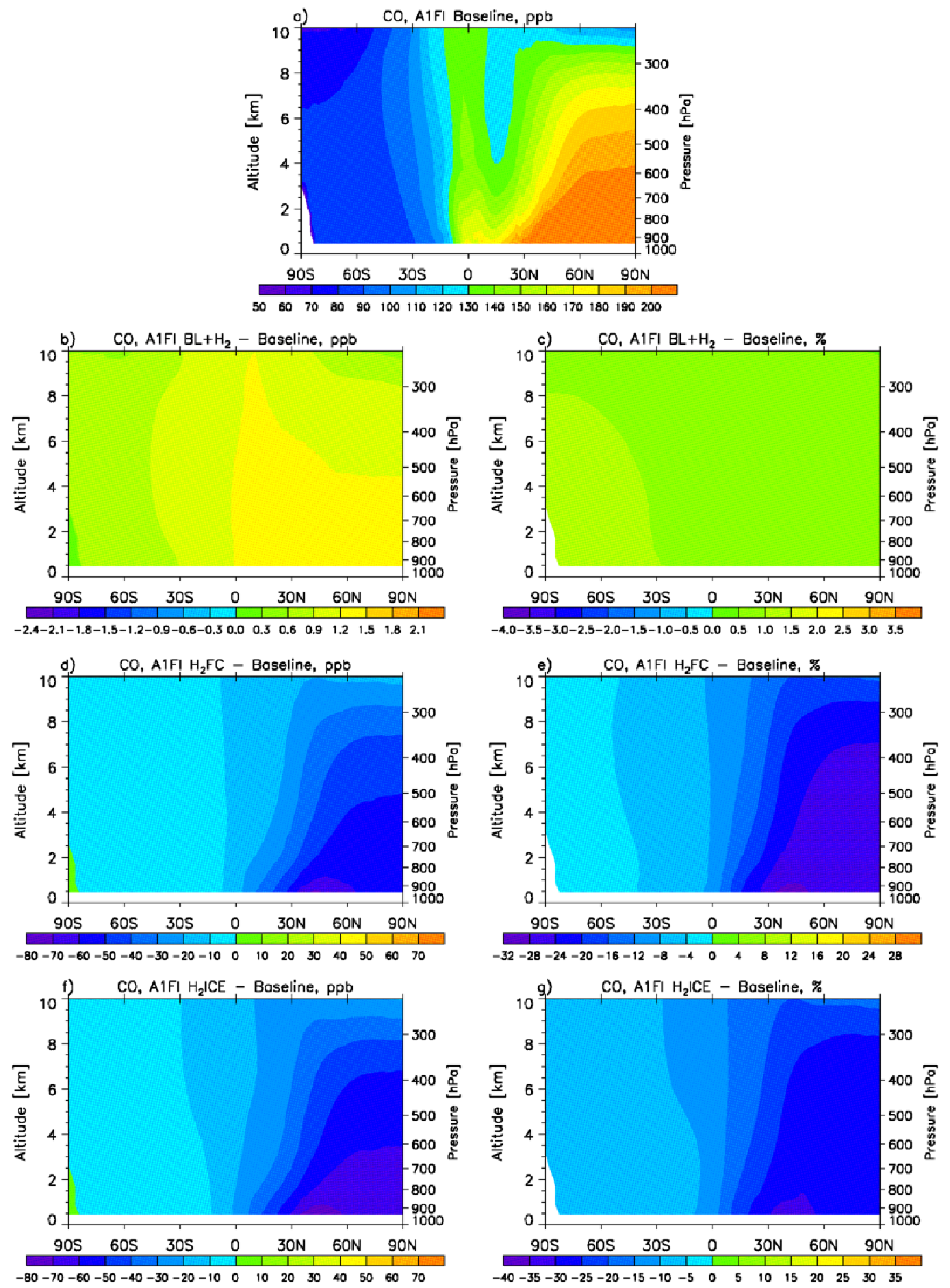

Figure 19. Change of annual, zonal mean $\mathrm{CO}$ mixing ratio between $\mathrm{A1FI}-\mathrm{BL}$ and $\mathrm{A1FI} \mathrm{H}_{2}$ scenarios. 

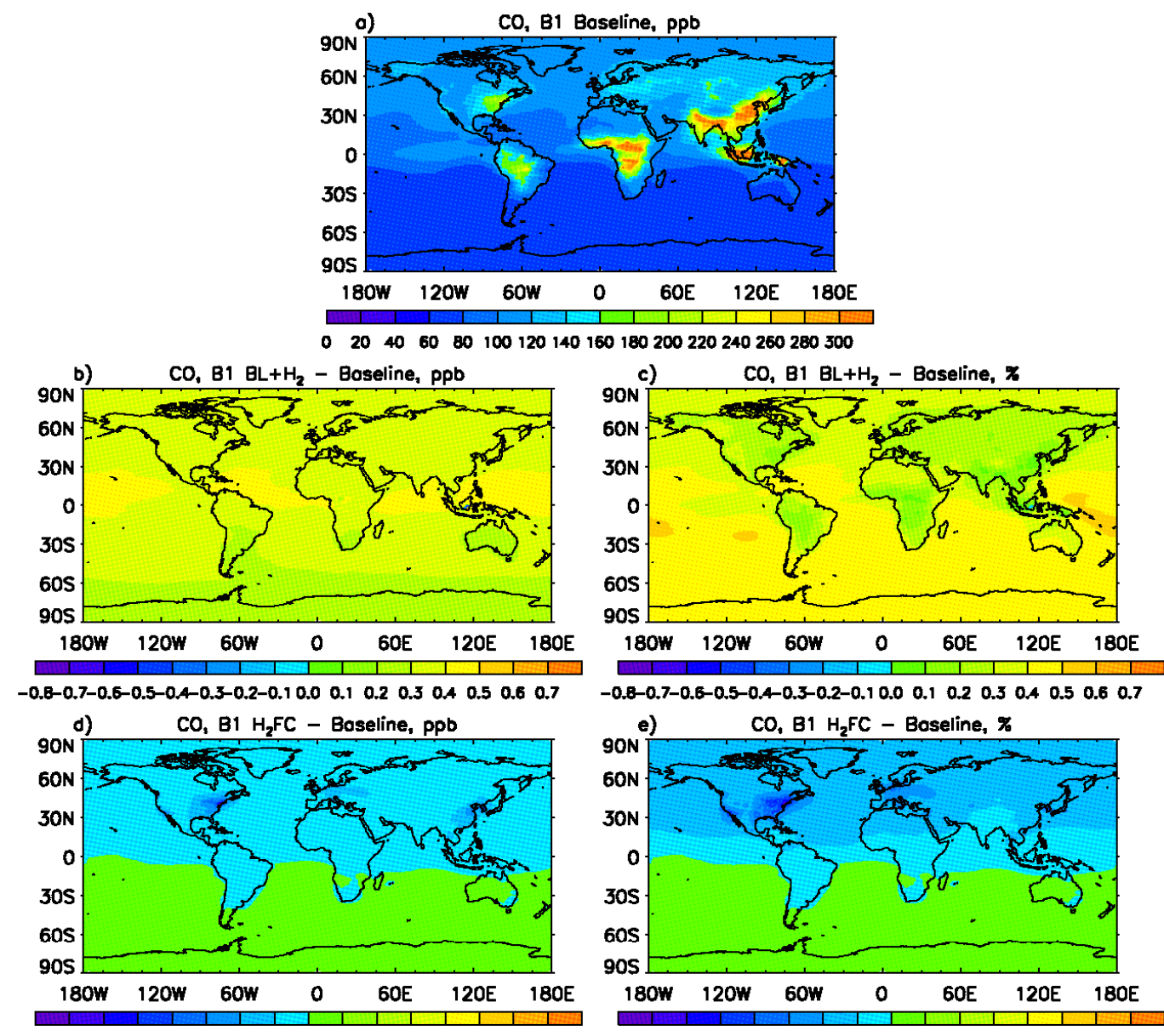

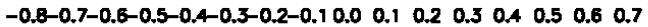
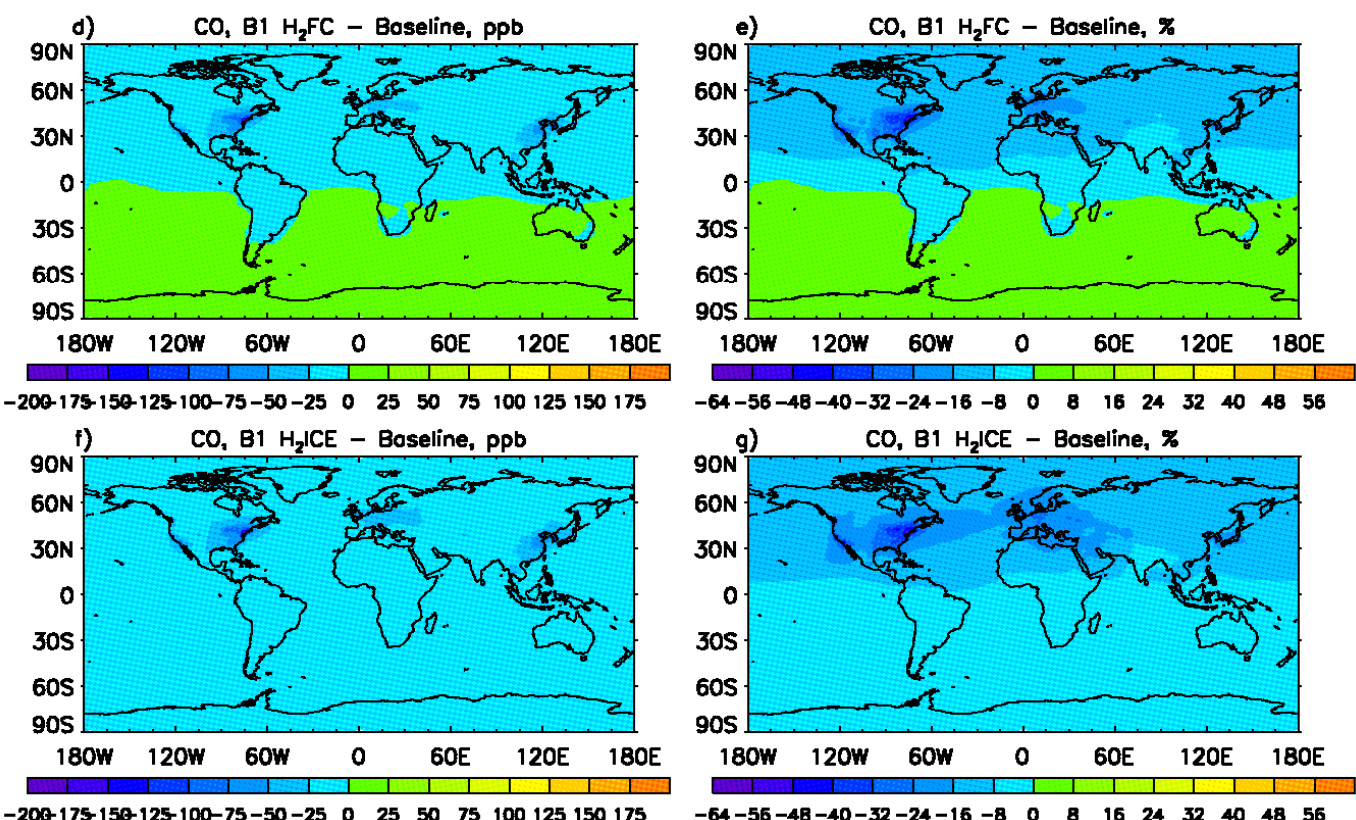

-200-175-150-125-100-75-50-25 O $25 \quad 5075100125150175$

$-64-56-48-40-32-24-16-8 \quad 0 \quad 8 \quad 16 \quad 24 \quad 32 \quad 4048 \quad 56$

Figure 20. Similar to Figure 18 except that these figures are for the B1 scenarios. 

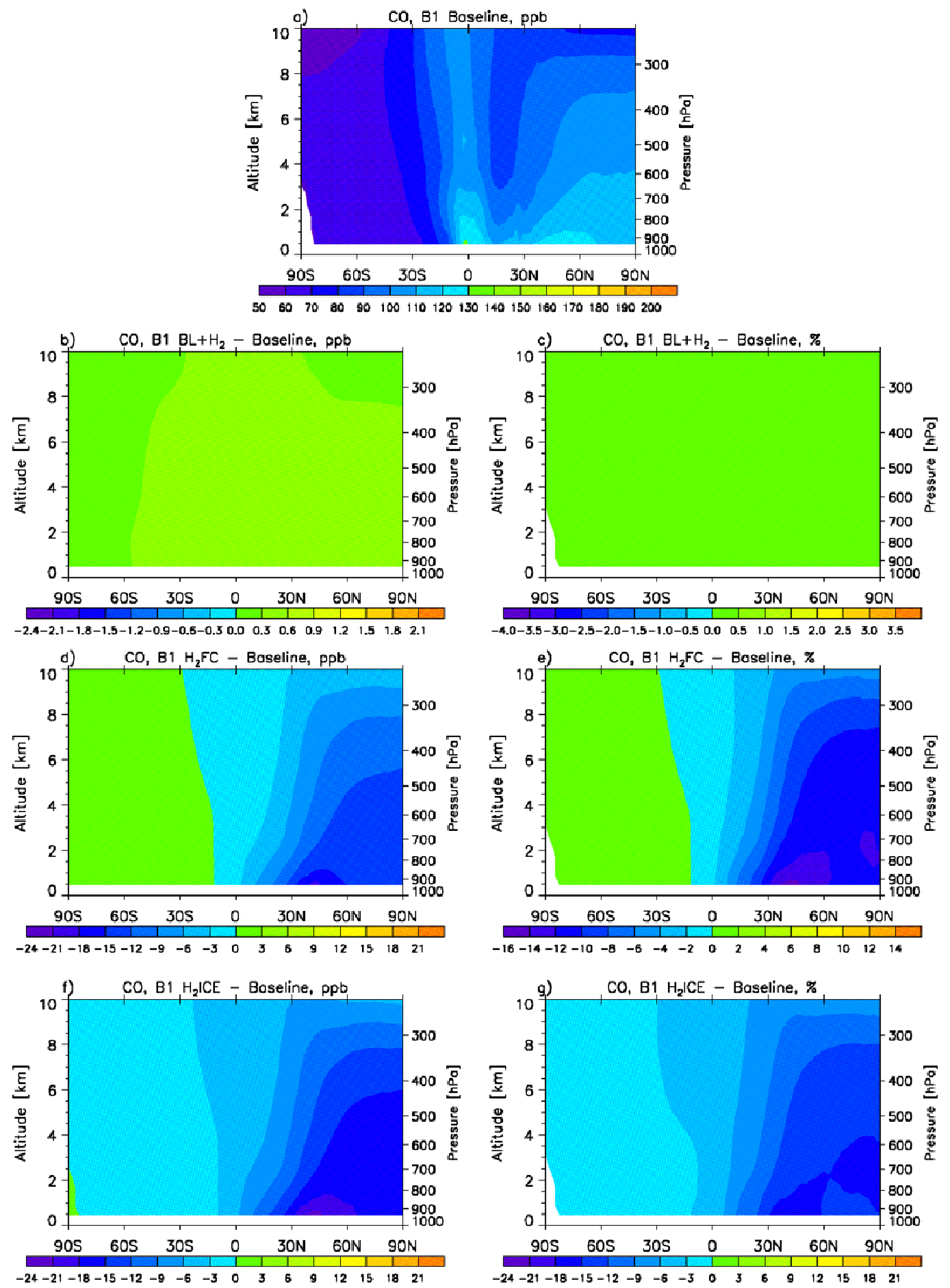

Figure 21. Similar to Figure 19 except that these figures are for the B1 scenarios. 

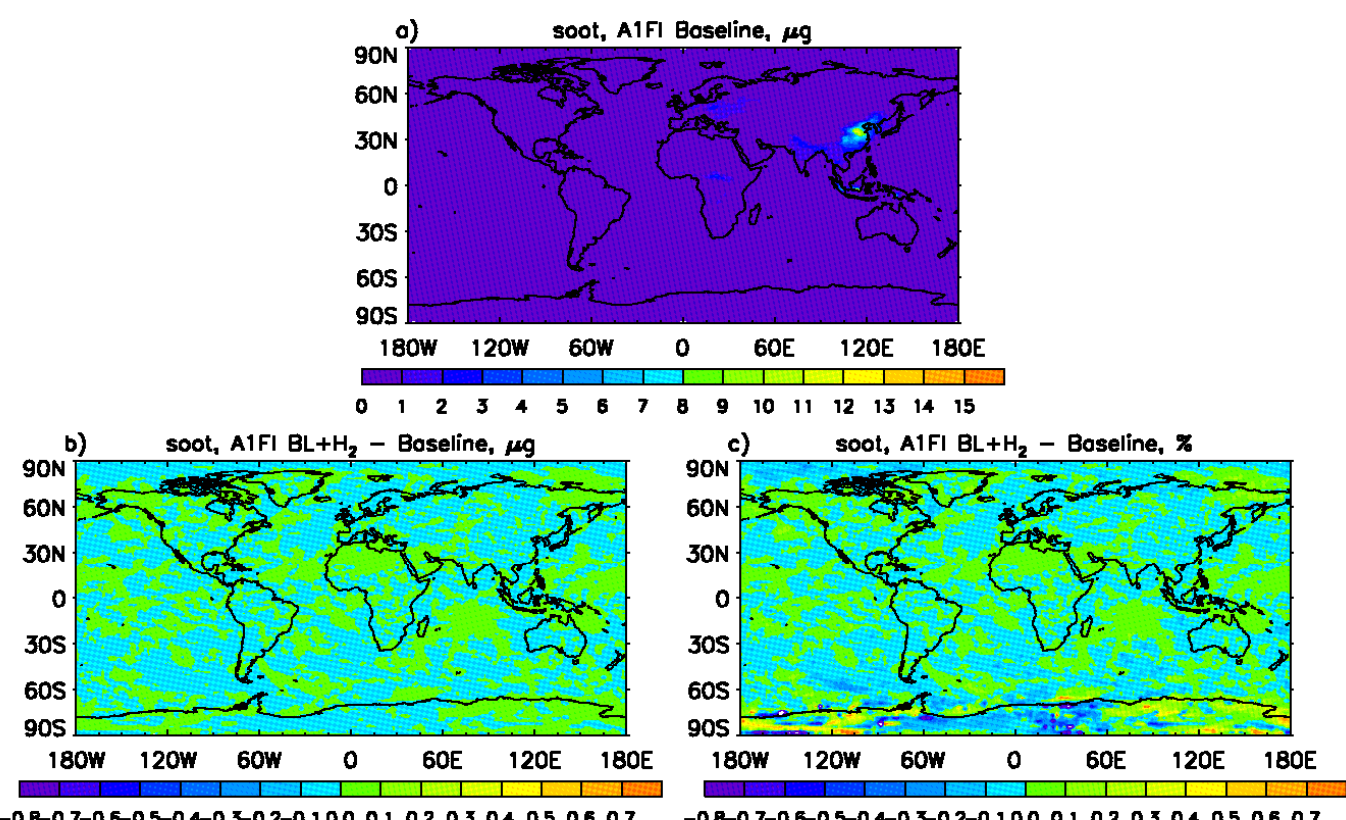

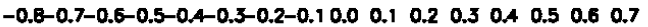

$\begin{array}{lllllllll}-0.8-0.7-0.6-0.5-0.4-0.3-0.2-0.1 & 0.0 & 0.1 & 0.2 & 0.3 & 0.4 & 0.5 & 0.6 & 0.7\end{array}$
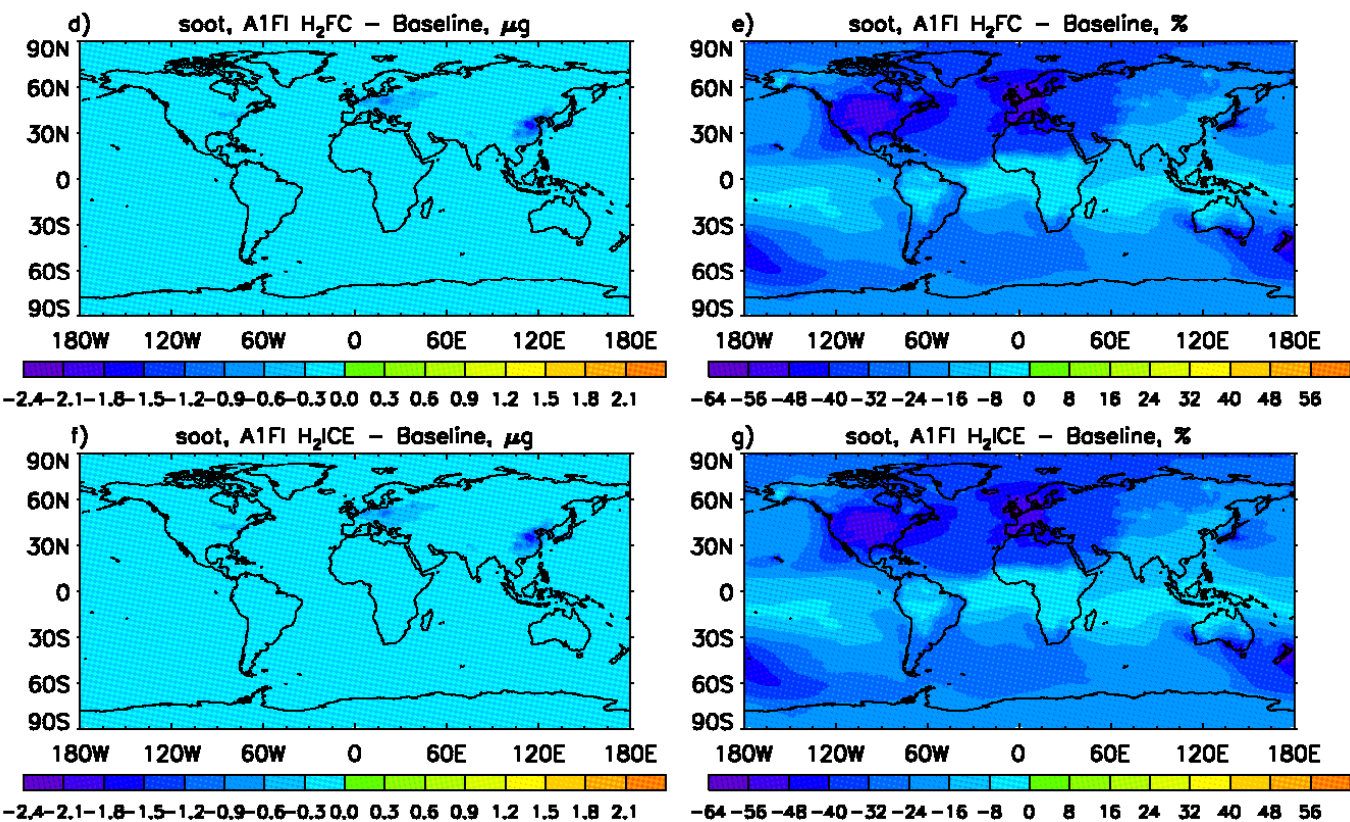

Figure 22. Change of annual mean ground level soot mass in $1 \mathrm{~m}^{3}$ between A1FI-BL and A1FI $\mathrm{H}_{2}$ scenarios. 


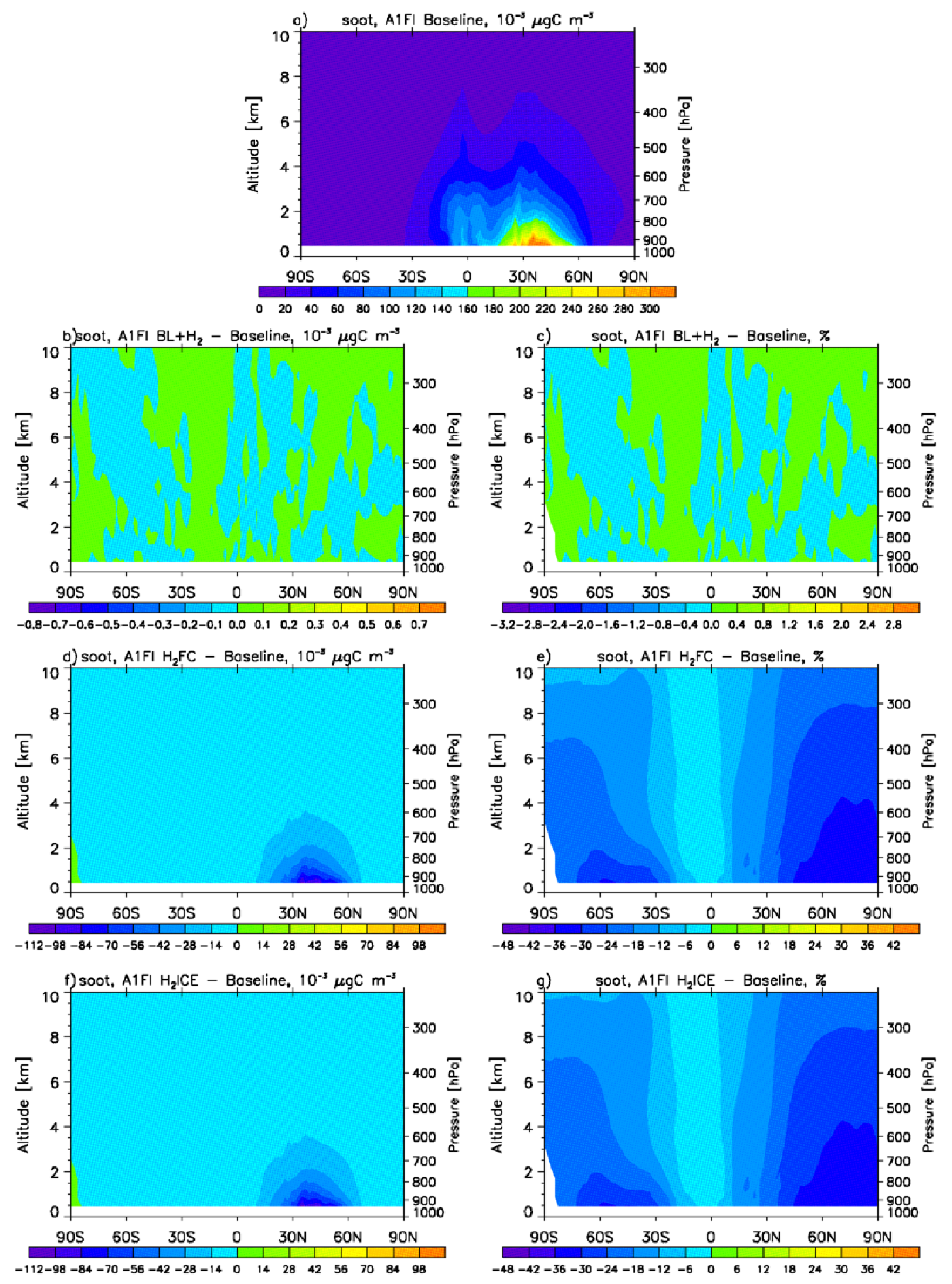

Figure 23. Change of annual, zonal mean soot concentration between A1FI-BL and A1FI $\mathrm{H}_{2}$ scenarios. 

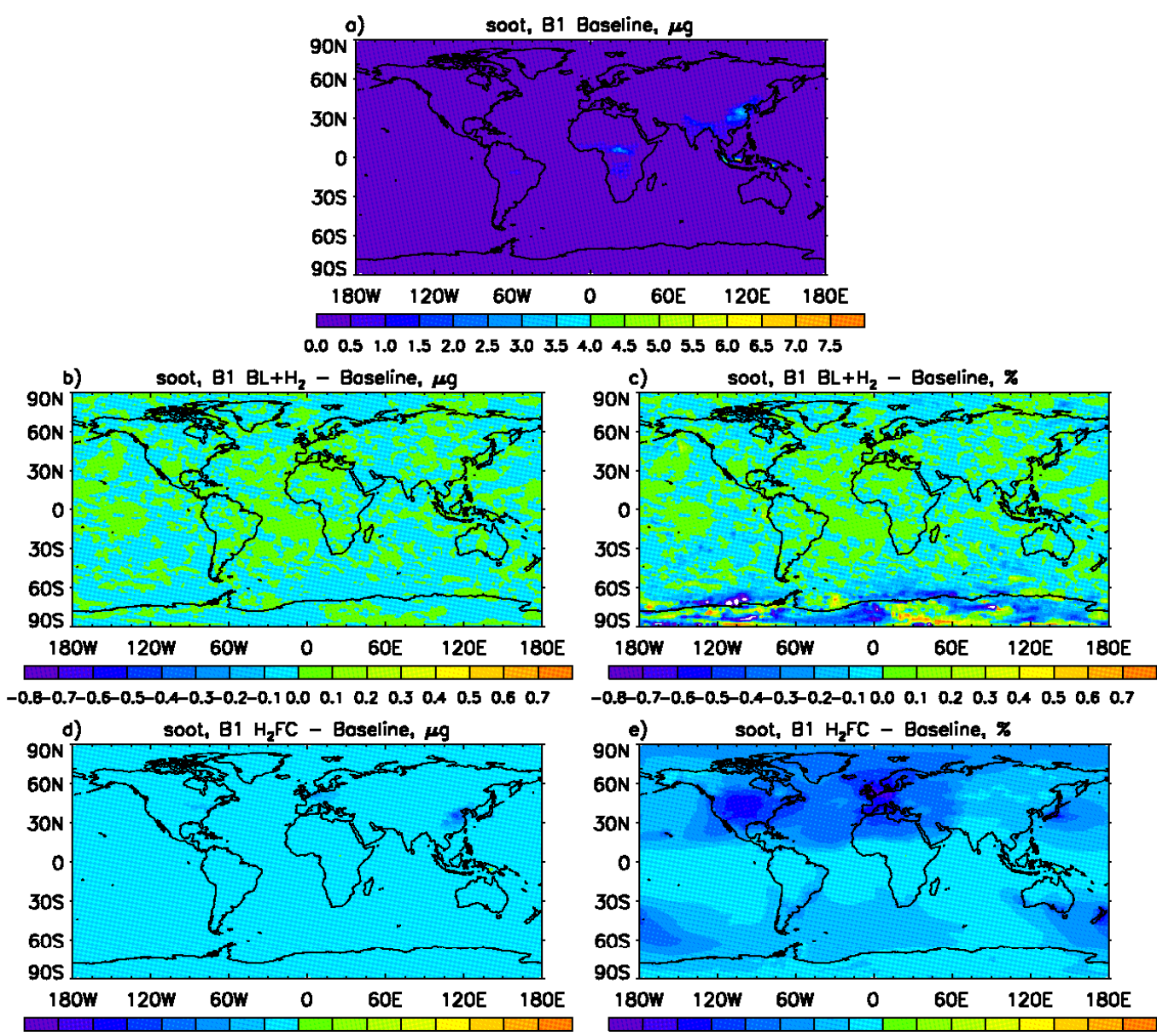

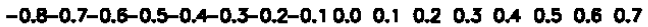
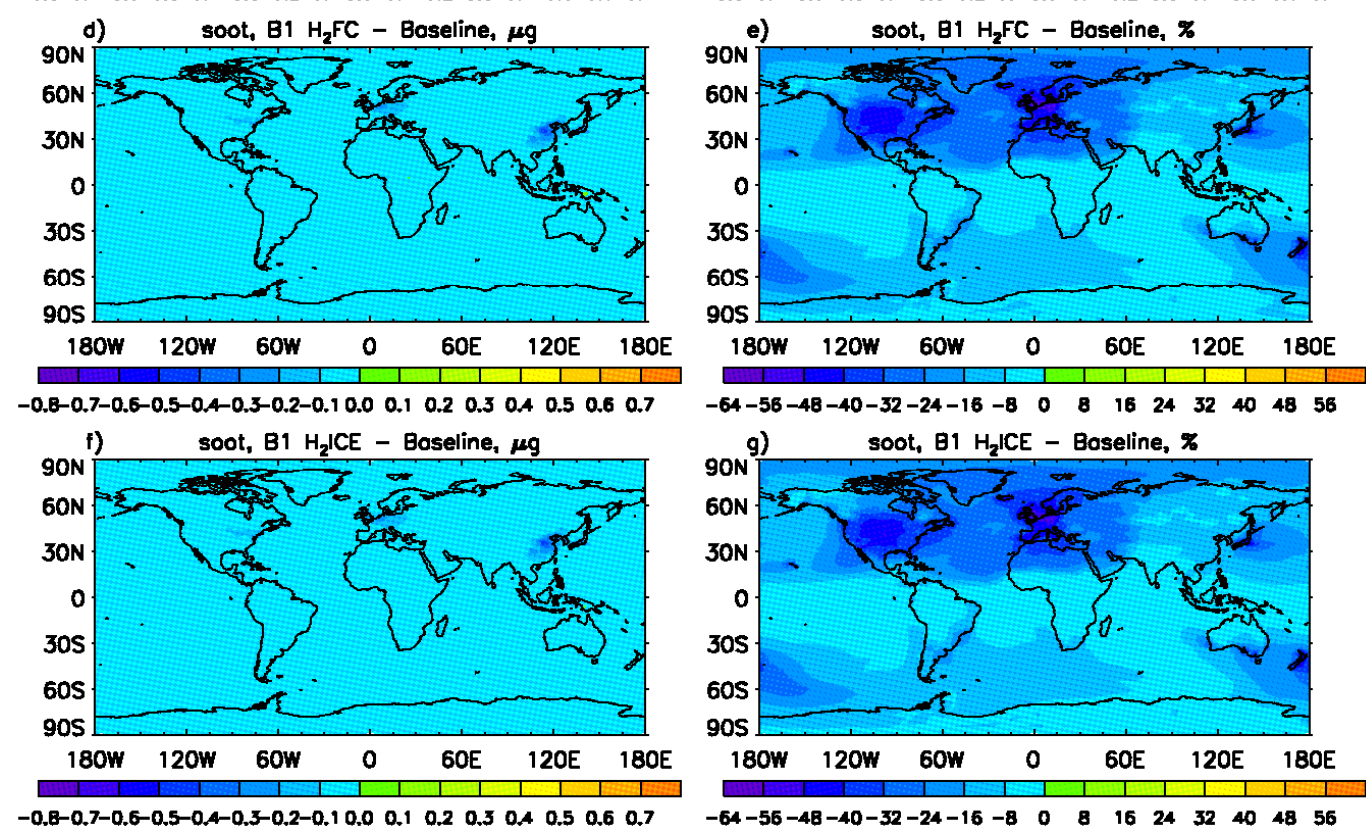

Figure 24. Similar to Figure 22 except that these figures are for the B1 scenarios. 


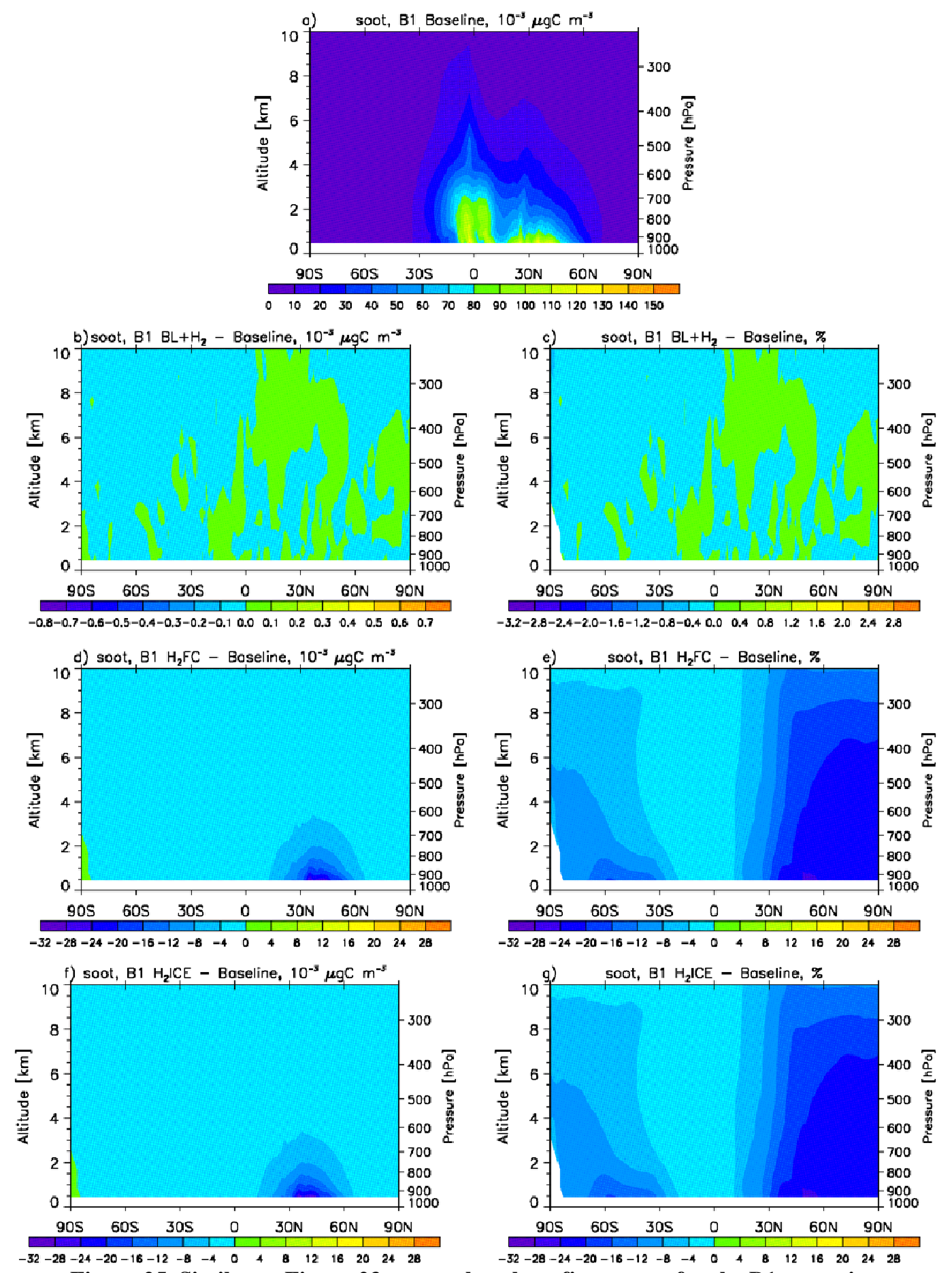

Figure 25. Similar to Figure 23 except that these figures are for the B1 scenarios. 

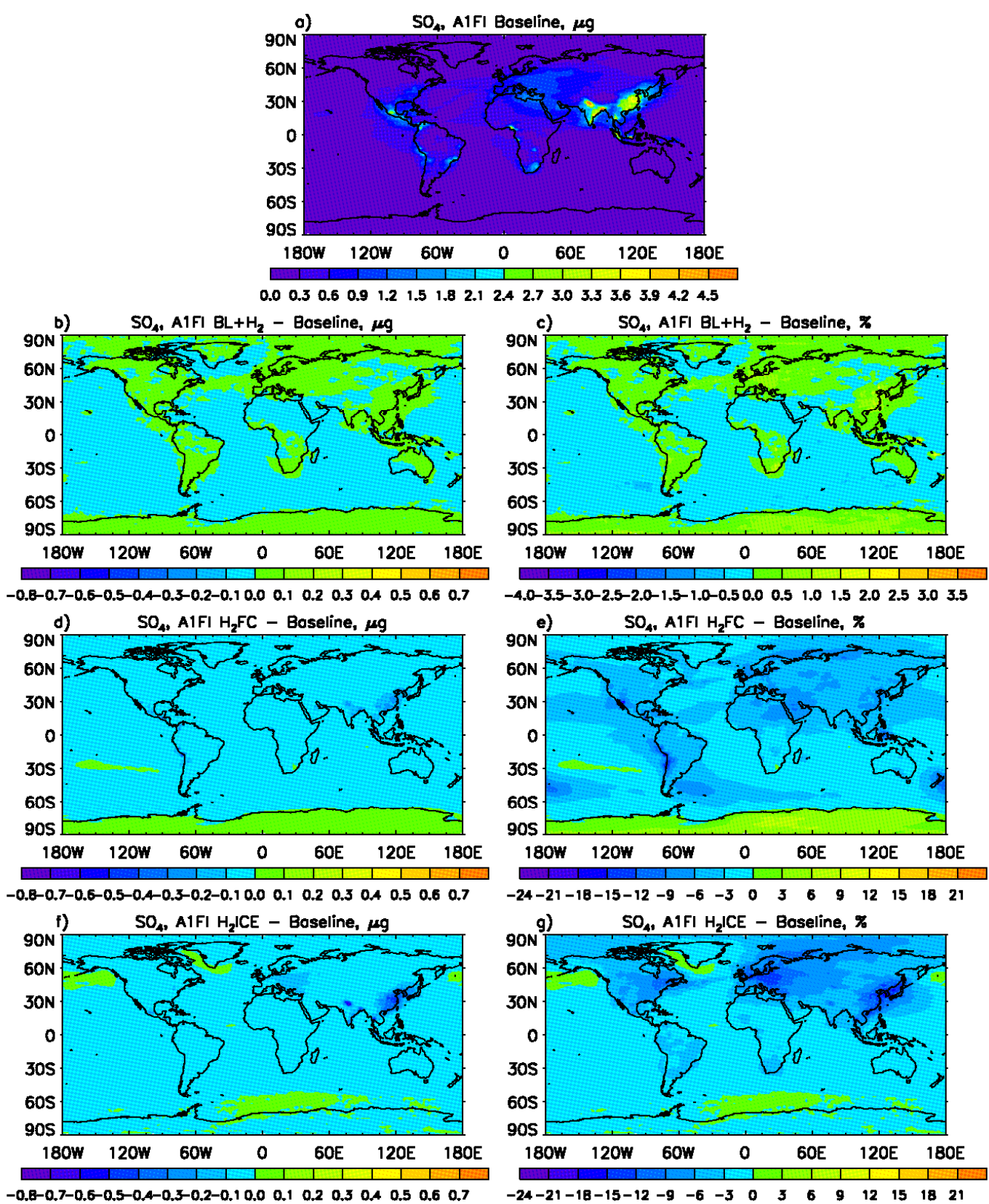

Figure 26. Change of annual mean ground level sulfate aerosol mass in $1 \mathrm{~m}^{3}$ between A1FI-BL and A1FI $\mathrm{H}_{2}$ scenarios. 


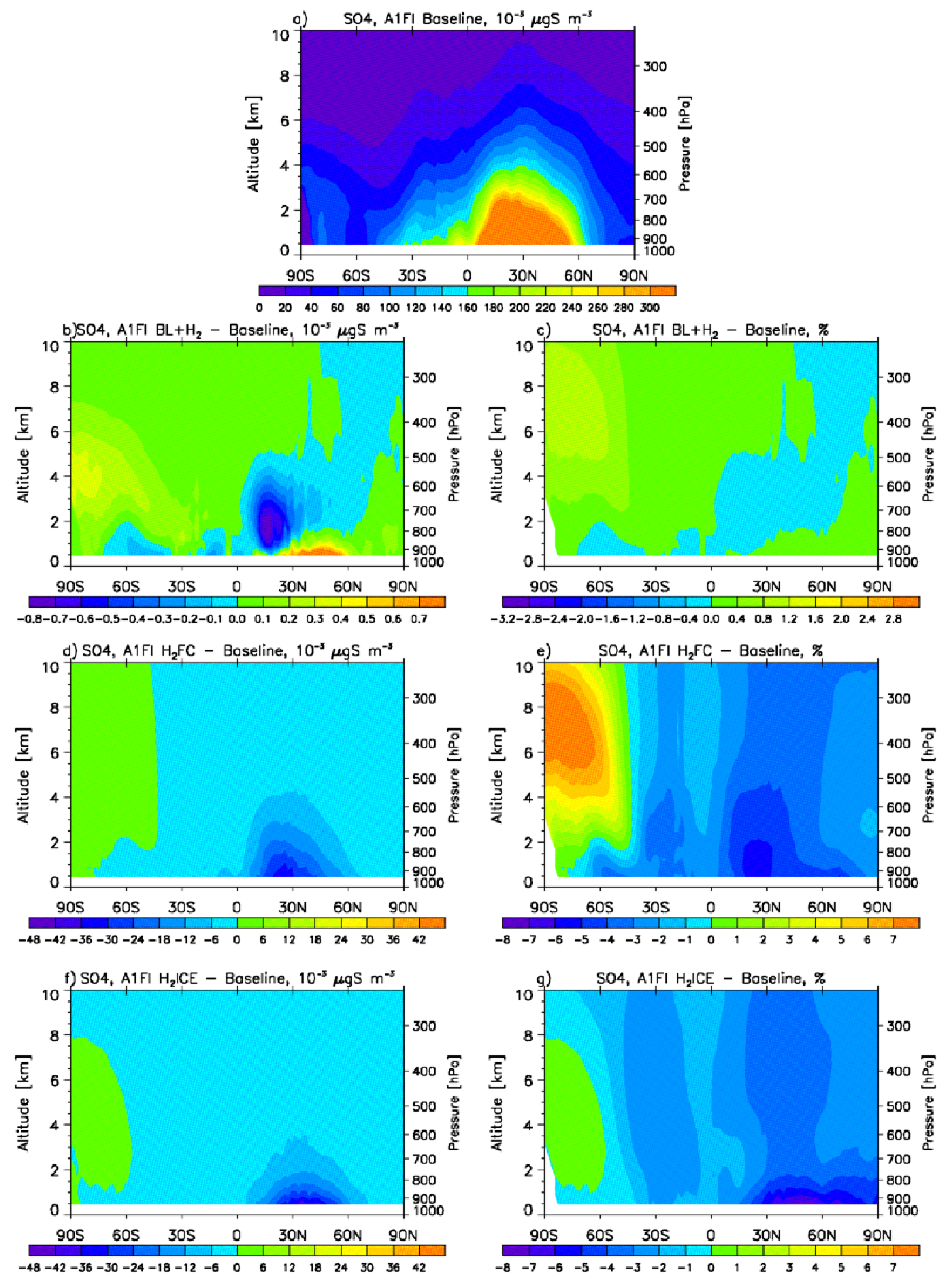

Figure 27. Change of annual, zonal mean sulfate aerosol concentration between A1FI-BL and A1FI $\mathrm{H}_{2}$ scenarios. 

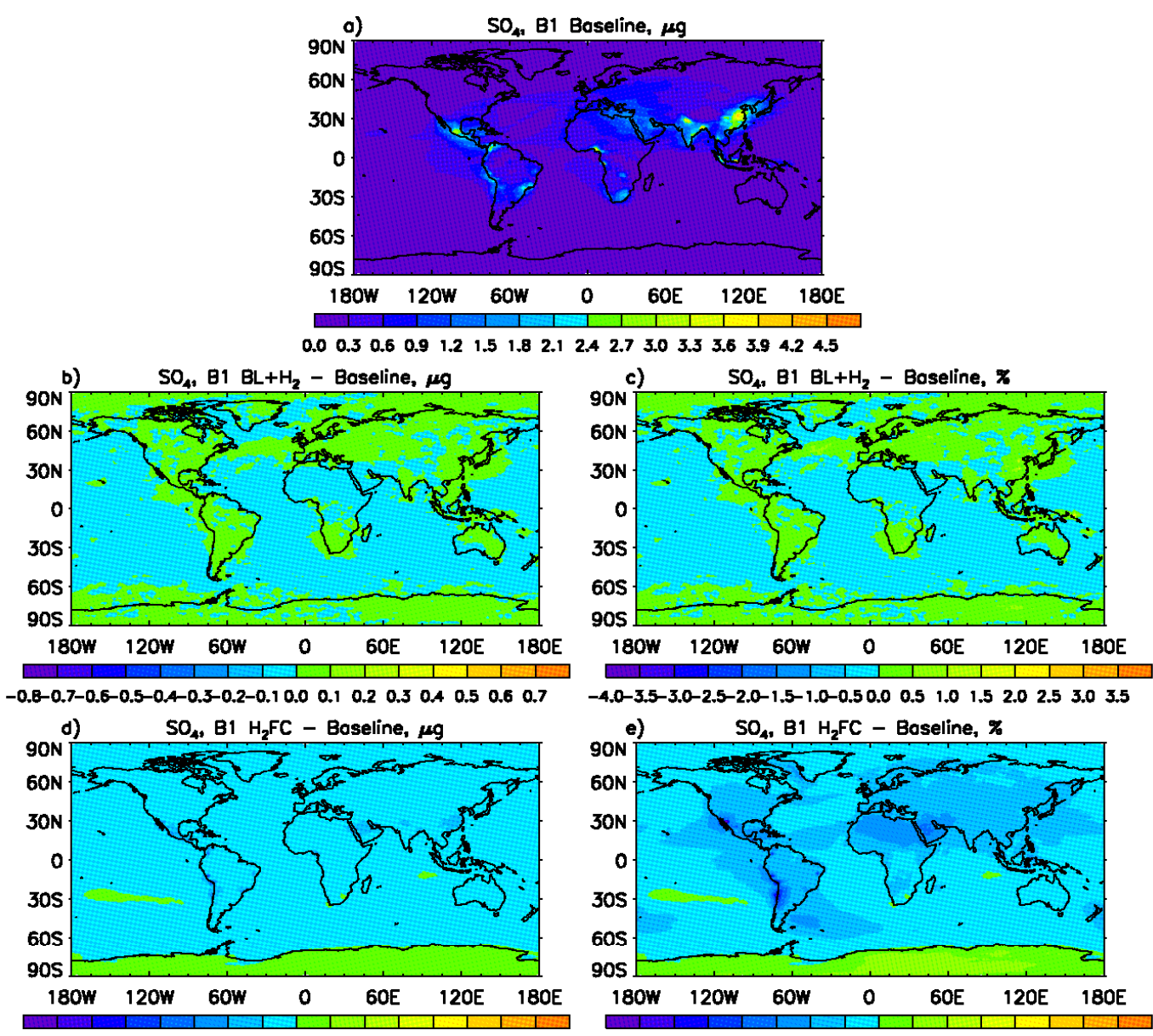

$-0.8-0.7-0.6-0.5-0.4-0.3-0.2-0.10 .0 \quad 0.1 \quad 0.2 \quad 0.30 .40 .5 \quad 0.6 \quad 0.7$
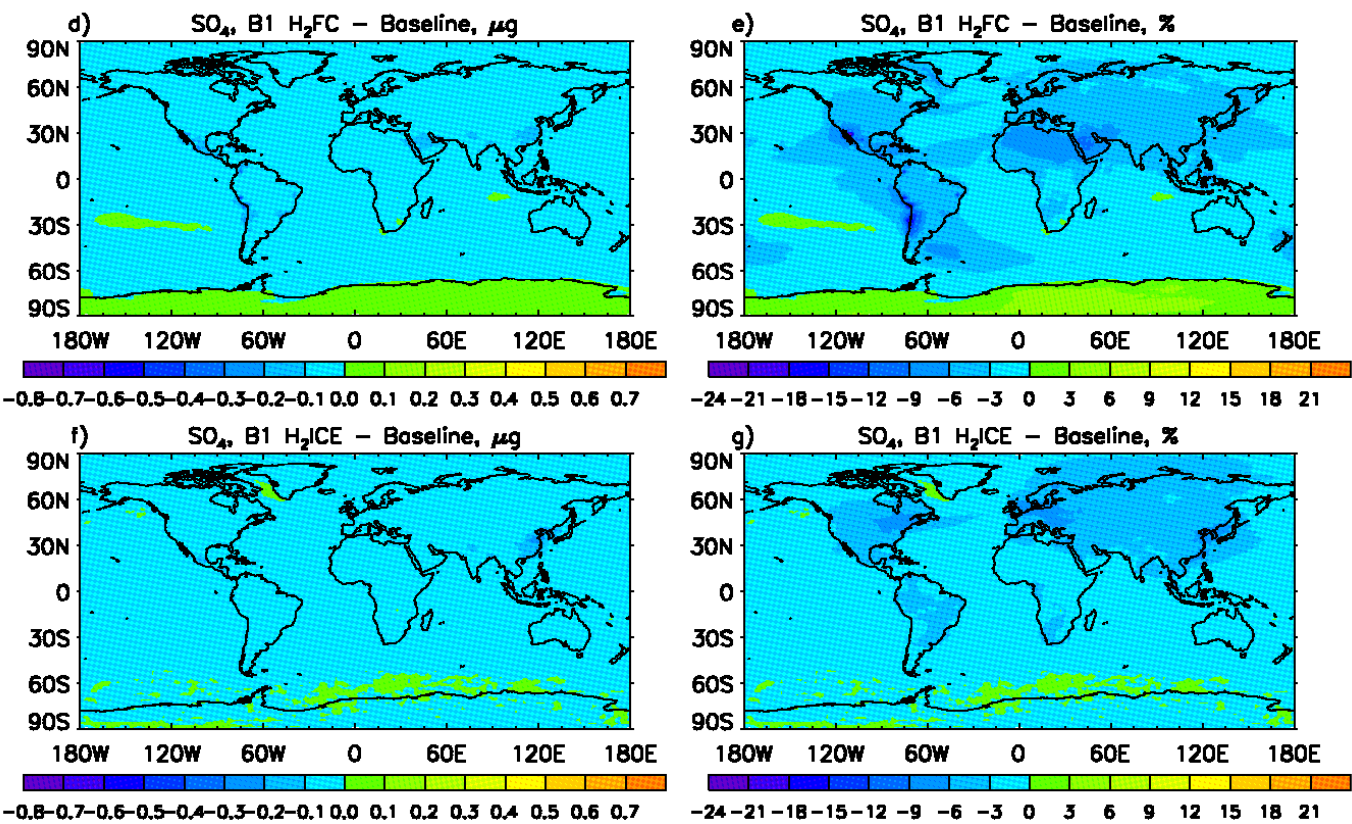

Figure 28. Similar to Figure 26 except that these figures are for the B1 scenarios. 


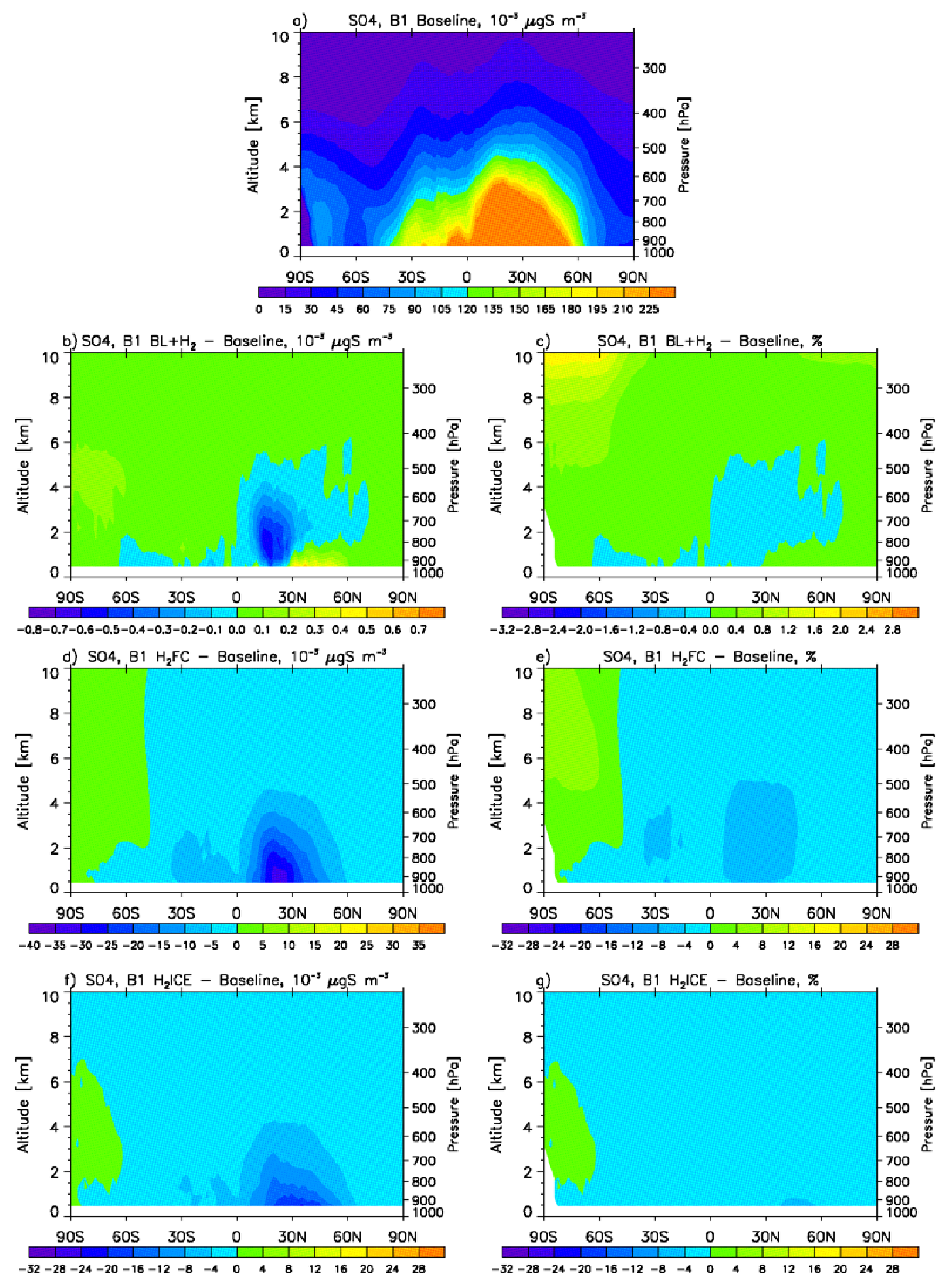

Figure 29. Similar to Figure 28 except that these figures are for the B1 scenarios. 

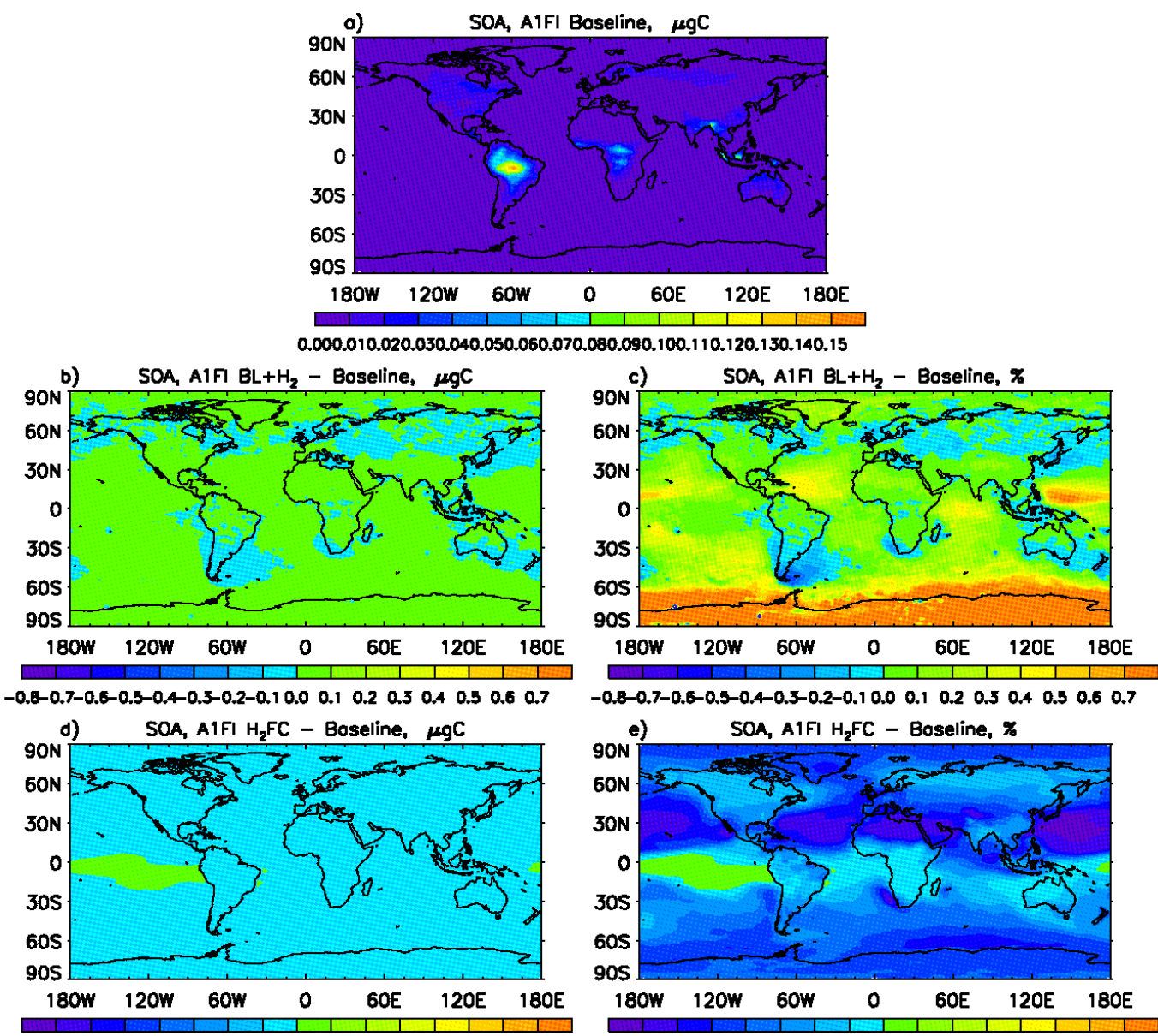

$\begin{array}{llllllllll}-0.8-0.7-0.6-0.5-0.4-0.3-0.2-0.1 & 0.0 & 0.1 & 0.2 & 0.3 & 0.4 & 0.5 & 0.6 & 0.7\end{array}$
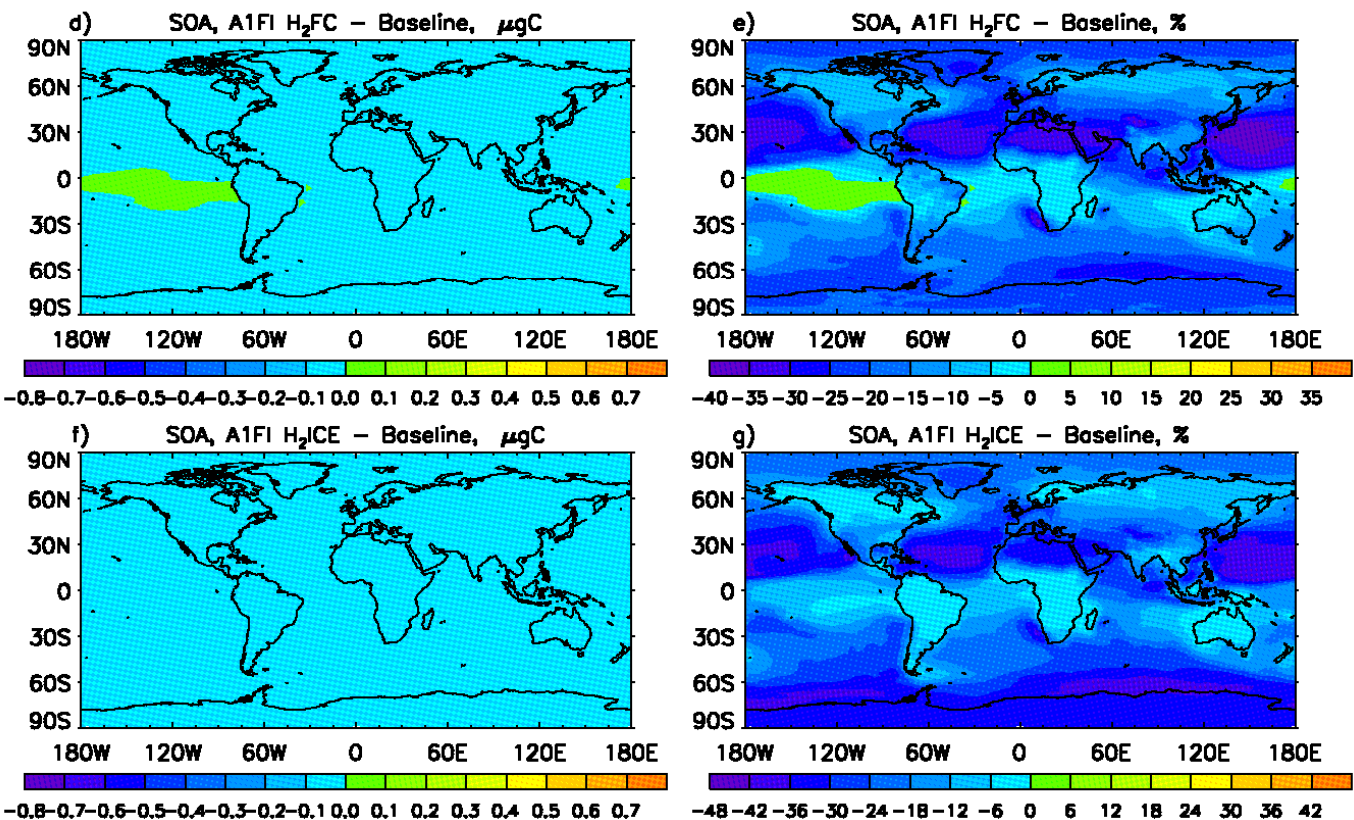

Figure 30. Change of annual mean ground level SOA mass in $1 \mathrm{~m}^{3}$ between A1FI-BL and A1FI $\mathrm{H}_{2}$ scenarios. 


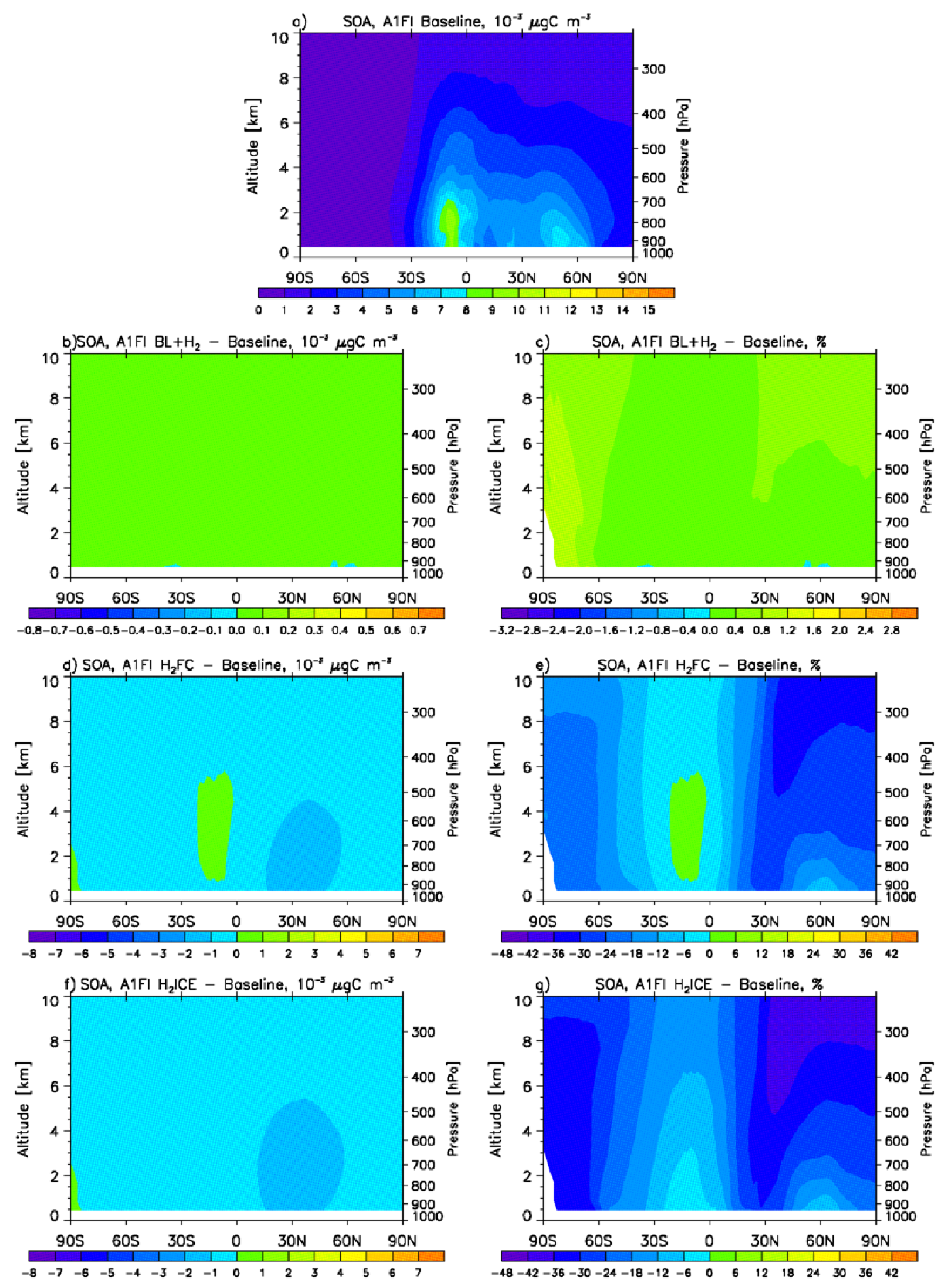

Figure 31. Change of annual, zonal mean SOA concentration between A1FI-BL and A1FI $\mathrm{H}_{2}$ scenarios. 

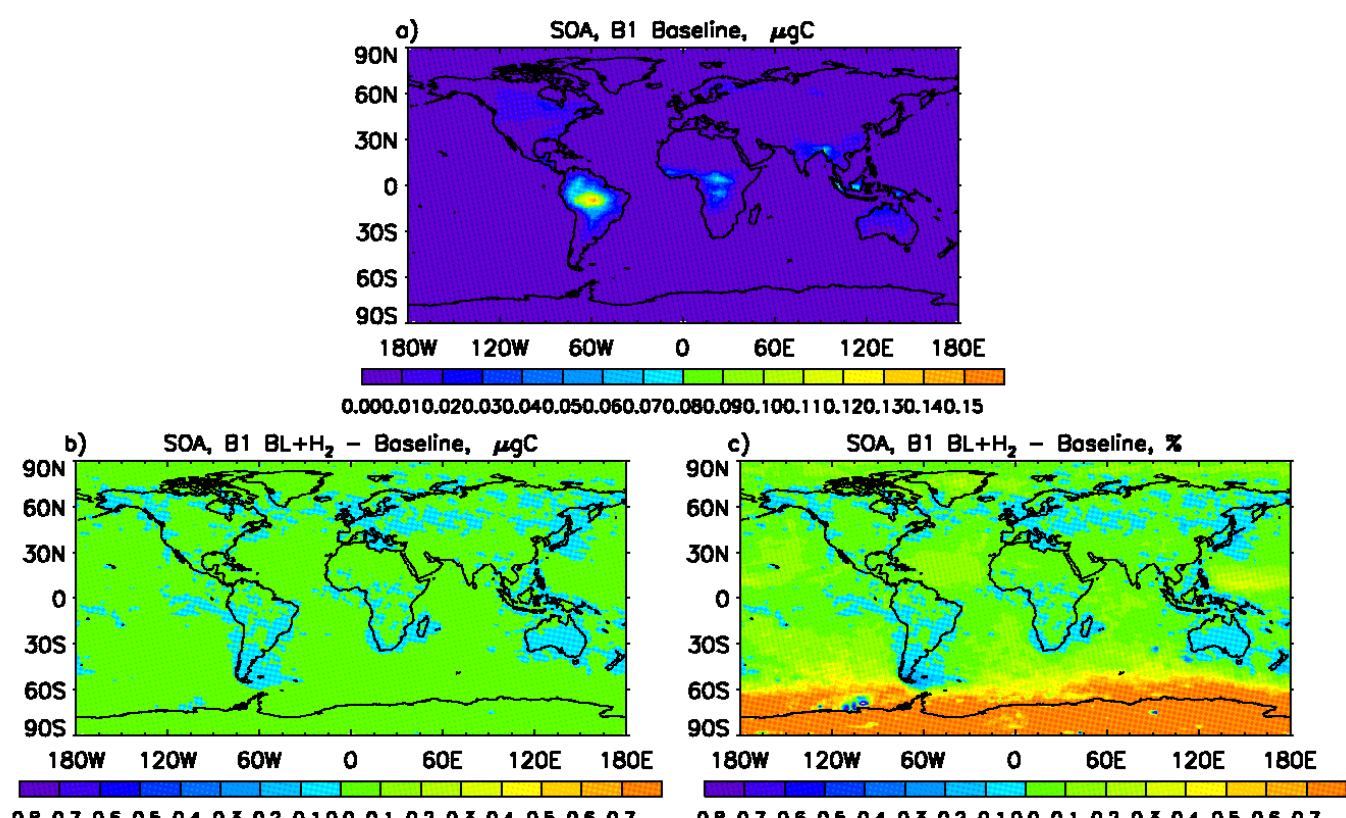

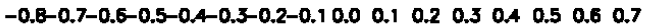

$-0.8-0.7-0.6-0.5-0.4-0.3-0.2-0.10 .0 \quad 0.10 .20 .30 .40 .50 .6 \quad 0.7$
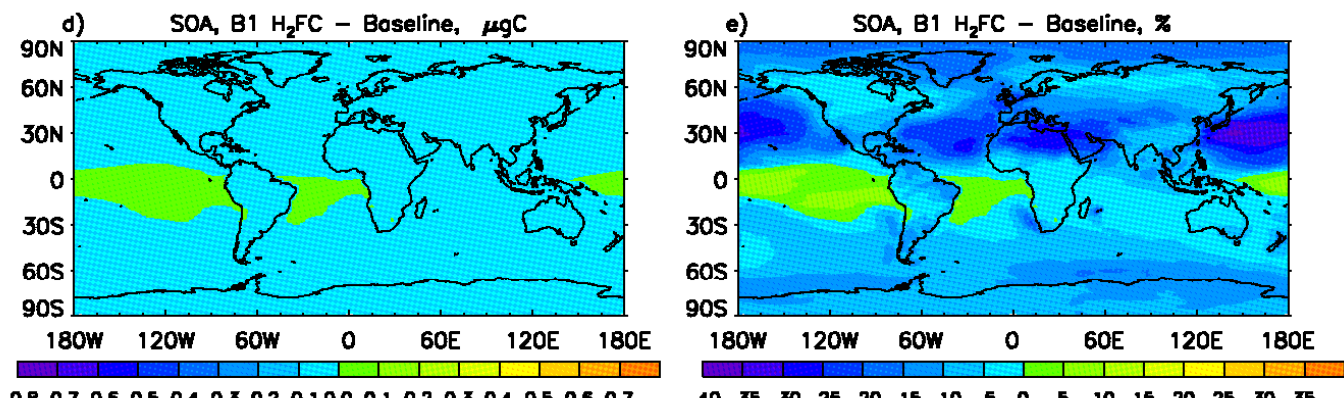

$\begin{array}{llllllllll}-0.8-0.7-0.6-0.5-0.4-0.3-0.2-0.1 & 0.0 & 0.1 & 0.2 & 0.3 & 0.4 & 0.5 & 0.6 & 0.7\end{array}$
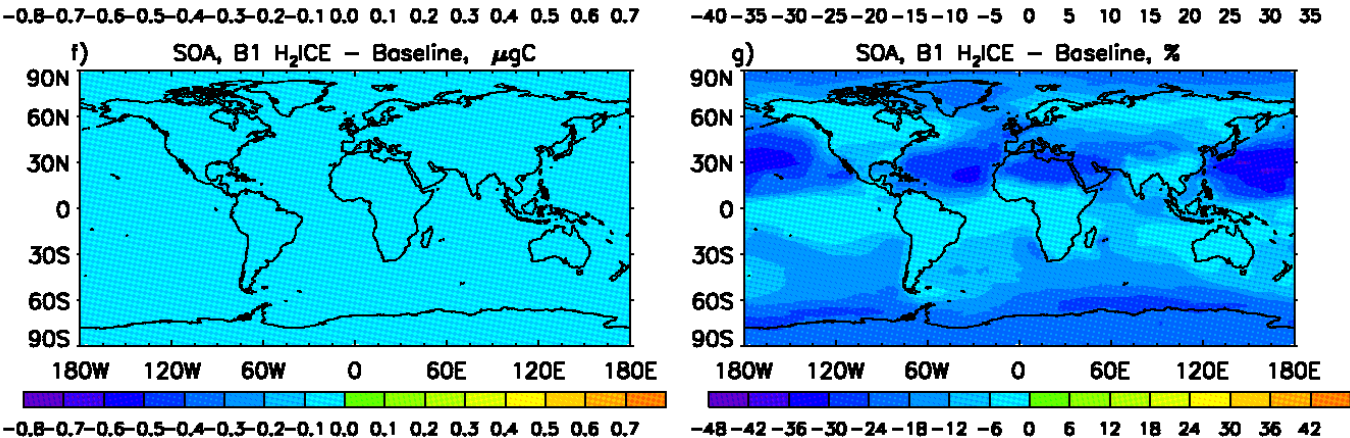

Figure 32. Similar to Figure 30 except that these figures are for the B1 scenarios. 


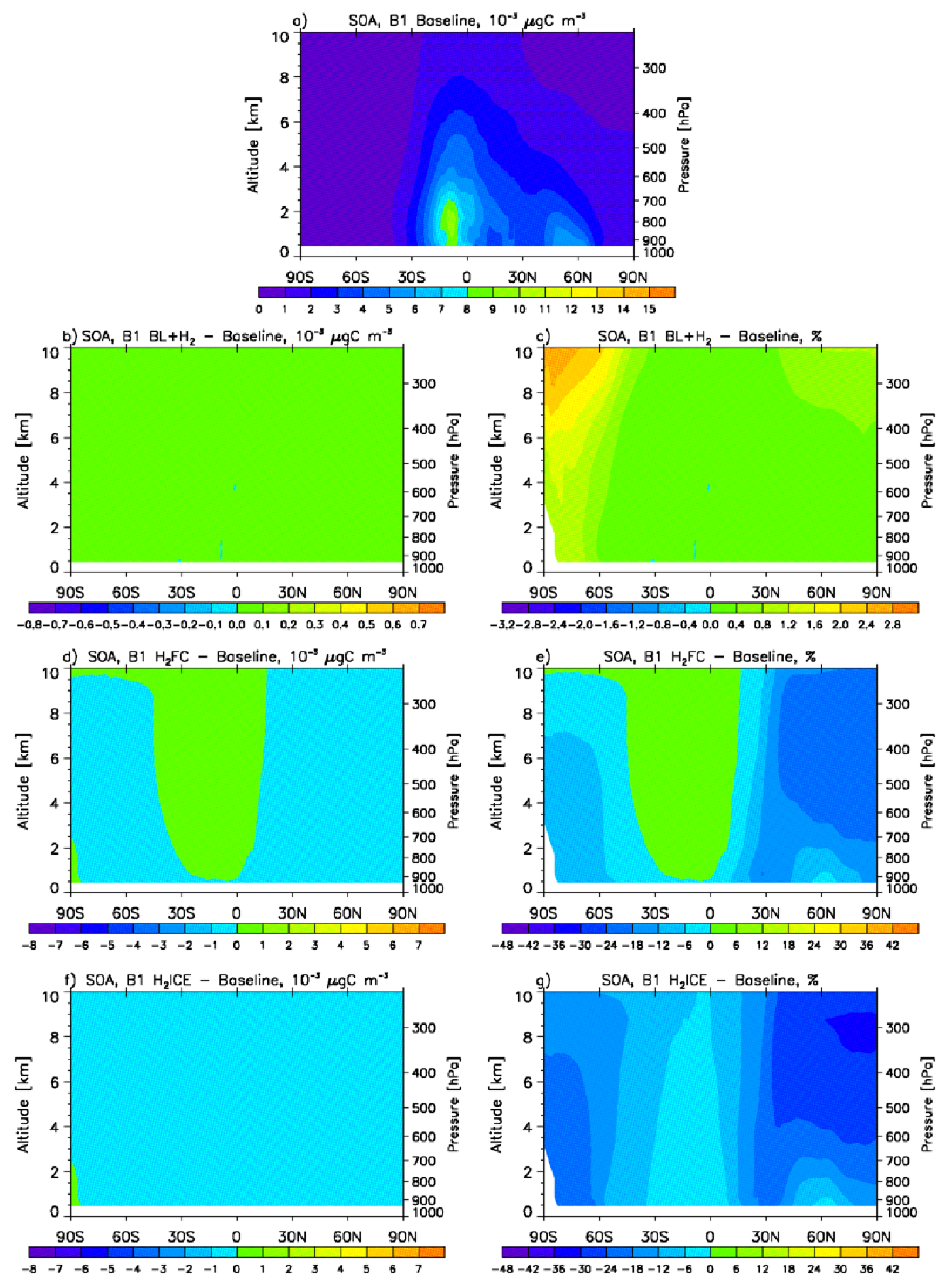

Figure 33. Similar to Figure 32 except that these figures are for the B1 scenarios. 
Appendix: Tropospheric ozone formation from $\mathrm{CO}$ and VOCs with the help of NOx

Below is the main chemical mechanism of ozone formation during $\mathrm{CO}$ oxidation process:

$$
\begin{aligned}
& \mathrm{CO}+\mathrm{OH} \rightarrow \mathrm{H}+\mathrm{CO}_{2} \\
& \mathrm{H}+\mathrm{O}_{2}+\mathrm{M} \rightarrow \mathrm{HO}_{2}+\mathrm{M} \\
& \mathrm{HO}_{2}+\mathrm{NO} \rightarrow \mathrm{OH}+\mathrm{NO}_{2} \\
& \mathrm{NO}_{2}+h v \rightarrow \mathrm{NO}+\mathrm{O} \\
& \mathrm{O}+\mathrm{O}_{2}+\mathrm{M} \rightarrow \mathrm{O}_{3}+\mathrm{M}
\end{aligned}
$$

If we add reactions 1 to 5 up, we can get the following reaction as the net reaction:

$\mathrm{CO}+2 \mathrm{O}_{2} \rightarrow \mathrm{CO}_{2}+\mathrm{O}_{3}$

Ozone formation during VOCs oxidation processes is more complicated, but we may see a simple example as the following:

$$
\begin{aligned}
& \mathrm{RH}+\mathrm{OH} \rightarrow \mathrm{H}_{2} \mathrm{O}+\mathrm{R} \\
& \mathrm{R}+\mathrm{O}_{2}+\mathrm{M} \rightarrow \mathrm{RO}_{2}+\mathrm{M} \\
& \mathrm{RO}_{2}+\mathrm{NO} \rightarrow \mathrm{RO}+\mathrm{NO}_{2}
\end{aligned}
$$

The generated $\mathrm{NO}_{2}$ can go through reactions 4 and 5 and form ozone. On the other hand $\mathrm{RO}$ can be further oxidized and more $\mathrm{NO}_{2}$ is generated during its oxidation, leading to even more ozone formation via reactions 4 and 5 . 


\title{
Section 3
}

\section{Impact of a Future Hydrogen-Based Road Transportation Sector on Stratospheric Composition and Chemistry}

\author{
Dong Wang, Wenjing Jia, Seth Olsen and Donald Wuebbles \\ Department of Atmospheric Sciences \\ University of Illinois at Urbana-Champaign
}

\section{Introduction}

Hydrogen $\left(\mathrm{H}_{2}\right)$ is being considered as a key fuel for energy and transportation systems of the future because it potentially offers a cleaner and more efficient energy carrier than fossil fuels. The large-scale adoption of $\mathrm{H}_{2}$ fuel in the road transportation sector could impact tropospheric and stratospheric ${ }^{*}$ atmospheric chemistry through leakage of $\mathrm{H}_{2}$ and reduced emissions of fossil fuel combustion byproducts. Our companion tropospheric and air quality impact study suggests that the emissions changes associated with the adoption of an $\mathrm{H}_{2}$ based road transportation sector could result in considerable air quality improvements in the troposphere, though the magnitude of the improvements would depend on the details of the technology adopted. The greatest air quality improvement would occur with the adoption of a fuel cell powered road transportation sector where the $\mathrm{H}_{2}$ is produced with non-polluting technologies. Here we evaluate the impact of these possible emissions changes on the composition and chemistry of stratospheric ozone.

Stratospheric ozone $\left(\mathrm{O}_{3}\right)$ is known as "good" ozone since it shields the biosphere from the Sun's ultraviolet radiation (UV), which can adversely affect the physiological wellbeing of humans, plants, and animals. The stratospheric ozone layer has previously been adversely impacted by the unforeseen consequences of emissions of compounds that were once believed to be 'safe'. Chlorofluorocarbons (CFCs) were widely used as refrigerants, propellants, and solvents. Their widespread use was due in part to their stability in the troposphere and long lifetimes (some CFCs have lifetimes of order 100 years). However due to their long atmospheric lifetimes these compounds are transported

\footnotetext{
* Stratosphere: the atmospheric layer situated between approximately $10 \mathrm{~km}$ to $50 \mathrm{~km}$ altitude, in which temperature increases with altitude.
} 
to the stratosphere where they degrade when exposed to intense sunlight (photolyze) releasing Chlorine $(\mathrm{Cl})$ and Bromine $(\mathrm{Br})$ compounds that actively destroy ozone. As a result stratospheric ozone levels have been decreasing since the 1980s with an average global decrease of 3\% (1997-2001 average relative to 1980) [WMO, 2002]. In order to avert a catastrophic decline in ozone The Montreal Protocol on Substances that Deplete the Ozone Layer was signed in 1987. The Montreal Protocol and its amendments are credited for the decrease in ozone destroying gases in recent years. The stratospheric ozone layer and the Antarctic ozone hole are currently projected to recover in the 2060 to 2070 timeframe [e.g., Newman, et al., 2006].

Given this past experience of unintended consequences of CFCs it is imperative to quantitatively assess the possible impact of an $\mathrm{H}_{2}$ based road transportation sector on stratospheric ozone. The chemical impact on the stratosphere could come from the change in emissions of $\mathrm{H}_{2}$ and fossil fuel combustion byproducts (the related chemical mechanisms are discussed in the stratospheric chemistry section). Here we evaluate the impact using emissions scenarios (described in the companion Emissions Scenario Report) based on the high and low emissions scenarios from Intergovernmental Panel on Climate Change (IPCC) future growth projections and atmospheric chemistry transport models.

\section{Method}

\section{Model description}

In this study, we used a chemistry transport model (CTM), Model for OZone And Related chemical Tracers (MOZART) version 3.1 [Kinnison et al., 2007], which has been developed by the National Center for Atmospheric Research (NCAR), and widely utilized in a number of studies by the atmospheric chemistry and climate community [e.g., Lamarque et al., 2008; Liu, et al., 2009a; Liu, et al., 2009b; Ordonez et al., 2010; Park et al., 2009; Youn et al., 2009]. The model simulates the atmosphere from the surface to $0.001 \mathrm{~Pa}$ level $(\sim 115 \mathrm{~km})$ by dividing it vertically into 60 layers. Horizontally the globe is partitioned into 96 grids on latitude and 144 grids on longitude, corresponding to a resolution of $1.9^{\circ} \times 2.5^{\circ}$ (latitude $\mathrm{x}$ longitude). It simulates in a detailed fashion the physical and chemical processes of the troposphere and stratosphere. 
It models 108 species, 71 photochemical reactions, 218 gas phase reactions and 18 heterogeneous reactions including heterogeneous chemistry in the stratosphere and polar stratospheric cloud processes. The model meteorology field is from a year of simulation of the Whole-Atmosphere Community Climate Model version 3 (WACCM3) [Garcia et al., 2007], which represents the mid-1990s atmosphere. This meteorology is repeated for each year of our multiyear simulations. We have chosen to use this meteorology since in this study we focus on emissions changes' impacts on photochemistry and because predicting meteorological changes in 2050 with any confidence is highly uncertain (in addition, previous studies [e.g., Lin et al., 2008] have shown that emissions changes will likely be more important than changes in climate on atmospheric composition and chemistry in the future). For more details about the model, see Kinnison et al. [2007].

\section{Scenarios description}

As mentioned earlier we evaluate the possible impact of an $\mathrm{H}_{2}$-based road transportation sector in the 2050 atmosphere based on the highest and lowest IPCC emissions scenarios, A1FI and B1, respectively. Given the large uncertainties in future projections, these scenarios were chosen to bracket the possible high and low impacts. In the A1FI scenario, the world is assumed to evolve with rapid economic growth and rely intensively on fossil fuel; whereas in the B1 scenario the world's economic structures are projected to change rapidly toward service-and-information intensive. For each of these two IPCC growth scenarios three emission scenarios were developed: 1) a Baseline emissions scenario without an $\mathrm{H}_{2}$-based road transportation sector, 2) an $\mathrm{H}_{2}$ fuel cell technology scenario $\left(\mathrm{H}_{2}-\mathrm{FC}\right)$ which utilizes $\mathrm{H}_{2}$ fuel cell powered transportation and includes $\mathrm{H}_{2}$ leakage emissions and reductions in fossil fuel combustion byproducts, e.g., $\mathrm{CO}, \mathrm{NO}_{\mathrm{x}}$, NMVOCs* , and 3) an $\mathrm{H}_{2}$ internal combustion engine scenario $\left(\mathrm{H}_{2}-\mathrm{FC}\right)$ in which the $\mathrm{H}_{2}$ is burned in conventional internal combustion engines such that there are $\mathrm{H}_{2}$ leakage emissions and decreases in CO and NMVOCs emissions as in scenario 2) but no decrease in $\mathrm{NO}_{\mathrm{x}}$ emissions. In 2050, for the A1FI scenario an $\mathrm{H}_{2}$-based transportation sector would decrease global CO, NMVOCs and $\mathrm{NO}_{\mathrm{x}}$ emissions by $25 \%, 14 \%$, and $29 \%\left(\mathrm{H}_{2}-\mathrm{FC}\right)$ or $0 \%\left(\mathrm{H}_{2}-\mathrm{FC}\right)$ whereas increase $\mathrm{H}_{2}$ emissions by $81 \%$. For the $\mathrm{B} 1$ scenario an $\mathrm{H}_{2}$-based transportation sector would decrease global CO, NMVOCs and $\mathrm{NO}_{\mathrm{x}}$ emissions by $10 \%$,

\footnotetext{
* NMVOCs is a collective term referring to non-methane volatile organic compounds.
} 
$8 \%$, and $24 \%\left(\mathrm{H}_{2}-\mathrm{FC}\right)$ or $0 \%\left(\mathrm{H}_{2}-\mathrm{FC}\right)$ while increase $\mathrm{H}_{2}$ emissions by $64 \%$. The annualmean global emissions for key species, $\mathrm{H}_{2}, \mathrm{CO}, \mathrm{NO}_{\mathrm{x}}$ and NMVOCs are listed in Table. 1. For more details see the detailed description in the companion Emissions Scenario Report. Note that the emissions of related species $\left(\mathrm{CO}, \mathrm{NO}_{\mathrm{x}}, \mathrm{NMVOCs}\right)$ are the same as those used in the tropospheric impact assessment except for carbonaceous particles and sulfur dioxide, which are not used in the MOZART model. Latitude dependent monthly varying lower boundary conditions for longer lived species $\left(\mathrm{N}_{2} \mathrm{O}, \mathrm{CFCs}, \mathrm{CH}_{4}\right)$ are taken from the appropriate IPCC scenario projections [IPCC, 2001]. The model was run for twelve years so as to reach an annually repeating steady state. Here we present results based on these scenarios.

\section{Results and discussion}

Our modeling studies suggest that the combined effect of increased $\mathrm{H}_{2}$ emissions and other emission changes in an $\mathrm{H}_{2}$-based road transport sector would tend to decrease ozone concentrations in the stratosphere in all scenarios except for the $\mathrm{B}_{1} \mathrm{H}_{2}$-ICE one. The overall effects on annual-, global-mean stratospheric column ozone are $-0.54 \%$, $0.23 \%,-0.20 \%$ and $+0.04 \%$ for A1FI $\mathrm{H}_{2}-\mathrm{FC}, \mathrm{A} 1 \mathrm{FI} \mathrm{H}_{2}-\mathrm{ICE}, \mathrm{B} 1 \mathrm{H}_{2}-\mathrm{FC}$ and B1 $\mathrm{H}_{2}-\mathrm{ICE}$ scenarios, respectively. Since interpretation of the stratospheric impact involves knowledge of stratospheric chemistry, please refer to the Appendix for background information.

\section{Baseline Scenarios}

The baseline 2050 atmospheres for IPCC A1FI and B1 scenarios (with fossil fuel transportation sector) are used as baselines in this study. The model simulations show that in the 2050 Baseline scenarios stratospheric ozone would recover to a significant extent compared with today's atmosphere (Figure. 1), as would be expected from future decline of atmospheric halogen concentrations. For the 2050 A1FI Baseline scenario there would be $\sim 13$ DU more ozone in the stratosphere than that for today (Figure. 1b), in terms of column ozone*. Whereas for the 2050 B1 Baseline scenario atmosphere, the stratospheric column ozone would be $\sim 11$ DU higher than that for today (Figure. 1c). The Antarctic

\footnotetext{
* Column ozone, often expressed in Dobson unit, refers to the amount of ozone in the atmospheric column under study. 1 DU is the amount of ozone that would be one thousandth of a centimeter thick at standard temperature and pressure, or $2.69 \times 10^{16} \mathrm{O}_{3}$ molecules $/ \mathrm{cm}^{-2}$.
} 
ozone hole would have recovered to a significant extent. The minimum total column ozone would be around $220 \mathrm{DU}$ at the southern polar region in October for both the A1FI and B1 Baseline scenarios, in contrast to the $150 \mathrm{DU}$ minimum ozone column today (Figure. 1a).

\section{Hydrogen Fuel Cell Scenarios}

The annual-, global-mean stratospheric column ozone for the $\mathrm{A} 1 \mathrm{FI} \mathrm{H}_{2}-\mathrm{FC}$ scenario would be reduced by $-0.54 \%$, or $1.5 \mathrm{DU}$. The reduction ranges from $0.4 \%$ to $1 \%$, or $1 \mathrm{DU}$ to 2.5DU, depending on latitude and time of a year (Figures. $2 \mathrm{a}$ and $2 \mathrm{~b}$ ). For the $\mathrm{B}_{1} \mathrm{H}_{2}-\mathrm{FC}$ scenario the mean stratospheric column ozone would be reduced by $-0.20 \%$, or $0.5 \mathrm{DU}$. The reduction ranges from $0.2 \%$ to $1 \%$, or $0.2 \mathrm{DU}$ to $1 \mathrm{DU}$ (Figures. 3a and $3 \mathrm{~b}$ ).

The relative reduction in ozone concentration is generally more pronounced at lower altitudes in the upper troposphere/lower stratosphere (UT/LS) region (Figure. $4 \mathrm{~b}$ and 5b), partly due to the reduced ozone production in the underlying troposphere due to reduced $\left[\mathrm{NO}_{\mathrm{x}}\right]^{*}$. (For more background information on tropospheric ozone chemistry, please refer to the companion tropospheric impact report.)

The most pronounced relative $\mathrm{O}_{3}$ reduction (up to $12 \%$ for the $\mathrm{A} 1 \mathrm{FI} \mathrm{H}_{2}-\mathrm{FC}$ scenario and up to $6 \%$ for the $\mathrm{B} 1 \mathrm{H}_{2}-\mathrm{FC}$ ) appears at approximately $13 \mathrm{~km}$ altitude around $15^{\circ} \mathrm{N}$ (Figures. $4 \mathrm{~b}$ and $5 \mathrm{~b}$ ). This maximum relative $\left[\mathrm{O}_{3}\right]$ decrease in the UT/LS region coincides with a strong relative reduction of $\left[\mathrm{NO}_{\mathrm{x}}\right]$ there (up to $16 \%$ for $\mathrm{A} 1 \mathrm{FI}$ and up to $10 \%$ for B1) (Figures. 6b and 7b), which slows down local ozone production. Meanwhile, as will be elucidated later, $\left[\mathrm{NO}_{\mathrm{x}}\right]$ decrease would lead to enhancement of $\mathrm{HO}_{\mathrm{x}}$ catalyzed cycles, which results in faster ozone loss $\left(\mathrm{NO}_{\mathrm{x}} / \mathrm{HO}_{\mathrm{x}}\right.$ coupling).

In the lower stratosphere where tropospheric origin ozone has relatively small impact (altitudes $>15 \mathrm{~km}$ at $35^{\circ} \mathrm{N}$, for example), catalytic cycles involving $\mathrm{HO}_{\mathrm{x}}$ overwhelm ozone destruction. Our model results confirm the overwhelming role of $\mathrm{HO}_{\mathrm{x}}$ cycles in ozone destructions in the lower stratosphere (Figures. 8b,c and 9b,c). $\mathrm{HO}_{\mathrm{x}}$ concentrations

\footnotetext{
* The species in bracket represents its concentration.
} 
are predicted to increase by up to $6 \%$ and $4 \%$ for both the A1FI and B1 scenarios, respectively (Figures. $10 \mathrm{~b}$ and $11 \mathrm{~b}$ ). This $\left[\mathrm{HO}_{\mathrm{x}}\right]$ increase enhances the $\mathrm{HO}_{\mathrm{x}}$-catalyzed ozone loss cycles (Figures. 12c,d and 13c,d). At the same time, as discussed in the appendix, the concomitant $\left[\mathrm{NO}_{\mathrm{x}}\right]$ reduction (Figures. $6 \mathrm{~b}$ and $7 \mathrm{~b}$ ) would impact the $\mathrm{HO}_{\mathrm{x}}$ cycles* via reactions (14) and (17), affecting $\left[\mathrm{HO}_{\mathrm{x}}\right]$ as well as the $\mathrm{HO}_{2} / \mathrm{OH}$ ratio. In this case, $\left[\mathrm{HO}_{2}\right]$ would increase due to decreased availability of NO in reaction (14), leading to enhanced ozone loss via reactions (7) and (15). Meanwhile, the rate of reaction (17) would fall as [NO] decreases, making reaction (17) a smaller $\mathrm{HO}_{\mathrm{x}}$ sink. Both of these effects tend to further enhance the $\mathrm{HO}_{\mathrm{x}}$-catalyzed ozone destruction cycle. The $\mathrm{HO}_{\mathrm{x}}$ cycles intensify by up to $3 \%$ and up to $2 \%$ for the A1FI and $\mathrm{B} 1 \mathrm{H}_{2}$-FC scenarios, respectively (Figures. 12c and 13c). In addition, a decrease in $\left[\mathrm{NO}_{\mathrm{x}}\right]$ would also lead to halogen cycles enhancement (Figures. 12c,d and 13c,d) via $\mathrm{NO}_{\mathrm{x}} /$ halogen cycles coupling. This enhancement would have a smaller impact on ozone concentrations since halogen cycles are only responsible for a few percent of ozone destruction in the lower stratosphere (Figures. 8b,c and 9b,c). To summarize, in the lower stratosphere $\mathrm{O}_{3}$ loss is dominated by $\mathrm{HO}_{x}$ catalyzed $\mathrm{O}_{3}$ destruction cycles and the decrease in ozone concentration in the $\mathrm{A} 1 \mathrm{FI}$ and $\mathrm{B} 1 \mathrm{H}_{2}-\mathrm{FC}$ scenarios is due to an intensification of these cycles.

In the middle stratosphere $(25-35 \mathrm{~km}$ altitude in the tropics, somewhat lower at higher latitudes), there exists a slight ozone increase (less than $0.4 \%$ ) for both A1FI and B1 $\mathrm{H}_{2}$ FC scenarios (Figures. $4 \mathrm{~b}$ and $5 \mathrm{~b}$ ). Even though ozone loss from $\mathrm{HO}_{\mathrm{x}}$ catalytic cycles increases due to $\left[\mathrm{HO}_{\mathrm{x}}\right]$ increase, the overall ozone loss is alleviated because $\mathrm{NO}_{\mathrm{x}}$ cycles dominate ozone loss in the middle stratosphere (Figures. 8b,c and 9b,c) and $\left[\mathrm{NO}_{\mathrm{x}}\right]$ is reduced there (Figures. 6b,c and 7b,c). The major source of $\mathrm{NO}_{\mathrm{x}}$ in the stratosphere is the reaction of $\mathrm{N}_{2} \mathrm{O}$ against $\mathrm{O}\left({ }^{1} \mathrm{D}\right)$. In this region where $\left[\mathrm{N}_{2} \mathrm{O}\right]$ and $\left[\mathrm{O}\left({ }^{1} \mathrm{D}\right)\right]$ are not significantly affected by the perturbation of an $\mathrm{H}_{2}-\mathrm{FC}$ sector, $\left[\mathrm{NO}_{\mathrm{x}}\right]$ decrease is due to enhancement of reaction (17), through which increased $\left[\mathrm{HO}_{\mathrm{x}}\right]$ makes this reaction a larger $\mathrm{NO}_{\mathrm{x}}$ sink and, likely due to decreases in $\left[\mathrm{NO}_{\mathrm{x}}\right]$ in the underlying atmosphere. Changes in $\left[\mathrm{NO}_{\mathrm{x}}\right]$ in the troposphere typically do not impact its concentrations in the stratosphere owing to its short lifetime. However, it is proposed that reactive nitrogen

\footnotetext{
* "HO $\mathrm{H}_{\mathrm{x}}$ cycles" is short for " $\mathrm{HO}_{\mathrm{x}}$-catalyzed ozone loss cycles". This also applies to other cycles hereafter.
} 
$\left(\mathrm{NO}_{\mathrm{y}}\right)$ in the upper troposphere over tropical regions can significantly impact on the lower stratosphere $\left[\mathrm{NO}_{\mathrm{y}}\right.$ ] [Ko et al., 1986] due to $\mathrm{NO}_{\mathrm{y}}$ 's longer lifetime. This is supported by observations [e.g., Murphy et al., 1993]. In this study, [NO $\mathrm{NO}_{\mathrm{y}}$ in the UT/LS region is about 1 ppb (parts per billion by volume) in all scenarios (Figures. 14 and 15), exceeding the threshold mixing ratio suggested by Murphy et al. [1993], which is $0.6 \mathrm{ppb}$. Therefore, $\left[\mathrm{NO}_{\mathrm{y}}\right]$ in the underlying atmosphere are likely to be significant enough to impact on stratospheric $\mathrm{NO}_{\mathrm{y}}$ abundance. In the $\mathrm{H}_{2}-\mathrm{FC}$ scenarios, $\left[\mathrm{NO}_{\mathrm{y}}\right]$ in the UT/LS region is significantly reduced ( $15 \%$ for A1FI and $8 \%$ for B1) (Figures. 14b and 15b), resulting in $\left[\mathrm{NO}_{\mathrm{x}}\right]$ declines in the above stratosphere. The $\mathrm{NO}_{\mathrm{x}}$ catalyzed ozone destruction cycle is reduced throughout most of the stratosphere (Figures. 12c and 13c), however, its impact on ozone concentrations is only apparent where $\mathrm{NO}_{\mathrm{x}}$ cycles dominate ozone destruction (Figures 8b,c and 9b,c). Therefore, slight ozone concentration increase is seen in the middle stratosphere in both of the $\mathrm{H}_{2}-\mathrm{FC}$ scenarios (Figures. $4 \mathrm{~b}, \mathrm{c} 5 \mathrm{~b}, \mathrm{c}$ $12 \mathrm{a}, \mathrm{b}$ and $13 \mathrm{a}, \mathrm{b})$ due to an attenuation of $\mathrm{NO}_{\mathrm{x}}$ catalyzed ozone destruction cycle (Figures. $12 \mathrm{c}, \mathrm{d}$ and $13 \mathrm{c}, \mathrm{d})$.

In the upper stratosphere, $\mathrm{HO}_{\mathrm{x}}$ catalyzed cycles again dominate ozone loss cycles (Figures $8 b, c$ and 9b,c). The $\left[\mathrm{HO}_{\mathrm{x}}\right]$ increase from enhanced $\mathrm{H}_{2}$ abundance and the decline in the rate of reaction (17) as a result of the $\left[\mathrm{NO}_{\mathrm{x}}\right]$ decrease leads to enhancement of $\mathrm{HO}_{\mathrm{x}}$ catalyzed cycles (Figures. 12c,d and 13c,d). The resulting $\left[\mathrm{O}_{3}\right]$ decline in this region is up to $1 \%$ for $\mathrm{A} 1 \mathrm{FI}$ and $\mathrm{B} 1 \mathrm{H}_{2}-\mathrm{FC}$ scenarios (Figures. $4 \mathrm{~b}$ and $5 \mathrm{~b}$ ), but the impact on total column ozone is relatively small owing to the low number concentrations there (Figures. $8 \mathrm{a}$ and $9 \mathrm{a})$.

\section{Hydrogen Internal Combustion Engine Scenarios}

The impact of the $\mathrm{H}_{2}$-ICE road transportation sectors on stratospheric ozone concentration is relatively modest compared with the corresponding $\mathrm{H}_{2}-\mathrm{FC}$ scenarios. The annual-, global-mean stratospheric column ozone for the A1FI $\mathrm{H}_{2}$-ICE scenario would be reduced by $-0.23 \%$, or $0.5 \mathrm{DU}$. The perturbation on mean stratospheric column ranges from $-0.8 \%$ to $+1 \%$, or $-2 \mathrm{DU}$ to $+2.5 \mathrm{DU}$, depending on latitude and time of a year (Figures. $2 \mathrm{c}$ and $2 \mathrm{~d}$ ). For the $\mathrm{B} 1 \mathrm{H}_{2}$-ICE scenario the mean stratospheric column ozone 
would be increased by $0.04 \%$, or $0.1 \mathrm{DU}$. The reduction ranges from $-0.2 \%$ to $+1 \%$, or $0.5 \mathrm{DU}$ to $+2.5 \mathrm{DU}$ (Figures. $3 \mathrm{c}$ and $3 \mathrm{~d}$ ).

One prominent feature distinguishing the $\mathrm{H}_{2}-\mathrm{ICE}$ scenarios from the $\mathrm{H}_{2}-\mathrm{FC}$ scenarios is that the $\left[\mathrm{NO}_{\mathrm{x}}\right]$ decrease in the stratosphere is not as significant in the $\mathrm{H}_{2}$-ICE scenarios as that in $\mathrm{H}_{2}-\mathrm{FC}$. For the $\mathrm{H}_{2}-\mathrm{ICE}$ scenarios, $\left[\mathrm{NO}_{\mathrm{x}}\right]$ increases in the lower and upper stratosphere for A1FI (Figures. 6d and 6e), and increases throughout the stratosphere for B1 (Figures. $7 \mathrm{~d}$ and $7 \mathrm{e}$ ). In the lower stratosphere $\left[\mathrm{NO}_{\mathrm{x}}\right]$ increases because of $\left[\mathrm{NO}_{\mathrm{x}}\right]$ increase throughout the troposphere since in the $\mathrm{H}_{2}$-ICE scenarios $\mathrm{NO}_{\mathrm{x}}$ is still emitted as combustion byproduct of internal combustion engines. In addition, $\mathrm{HO}_{\mathrm{x}}$ concentrations decrease in the troposphere due to the reduced NMVOCs emissions (NMVOCs oxidation provides a $\mathrm{HO}_{\mathrm{x}}$ source in the upper troposphere). The decrease in $\left[\mathrm{HO}_{\mathrm{x}}\right]$ decreases the $\mathrm{NO}_{\mathrm{x}}$ loss due to reaction (17), which in turn enhances [ $\left.\mathrm{NO}_{\mathrm{x}}\right]$.

For the A1FI $\mathrm{H}_{2}$-ICE scenario the relative perturbation on the catalytic ozone loss cycles is about half of that for the A1FI $\mathrm{H}_{2}$-FC scenario (Figures. 12g and 12h). The combined impact is a smaller in magnitude but more spatially dispersed $\left[\mathrm{O}_{3}\right]$ increase in the middle stratosphere (Figures. $4 \mathrm{~d}$ and $4 \mathrm{e}$ ). However, this widespread $\left[\mathrm{O}_{3}\right]$ increase would not fully compensate the $\left[\mathrm{O}_{3}\right]$ decrease in the lower stratosphere because ozone is denser in terms of molecular number concentration there (Figure. 8a). The global-mean column ozone in the stratosphere would still be $0.23 \%$ less than that in the A1FI Baseline atmosphere.

For the $\mathrm{B} 1 \mathrm{H}_{2}$-ICE scenario there would be negligible impact on all cycles except for the halogen catalyzed ones (Figures. 13g and 13h). The ozone loss rate of halogen catalyzed cycles decreases by about $2 \%$, resulting in a slight $\left[\mathrm{O}_{3}\right]$ increase. The impact of increased $\mathrm{NO}_{\mathrm{x}}$ catalyzed cycles on ozone in the lower stratosphere is "buffered" by decrease in halogen catalyzed cycles. (Increased $\left[\mathrm{NO}_{\mathrm{x}}\right]$ leads to slower halogen catalyzed cycles via halogen/ $\mathrm{NO}_{\mathrm{x}}$ coupling, like a buffer, see Nevison et al., 1999.) In the upper stratosphere, enhanced $\mathrm{HO}_{\mathrm{x}}$ catalyzed cycles are compensated by alleviated halogen cycles. The resulting ozone loss rate is decreased throughout the stratosphere (Figure. 13h). Zonal mean $\left[\mathrm{O}_{3}\right]$ increases slightly throughout the middle and upper stratosphere (Figures. $5 \mathrm{~d}$ and 5e). In the lower stratosphere, $\left[\mathrm{O}_{3}\right]$ decreases in the tropics and northern hemisphere 
due to tropospheric impact, but increases in the southern high latitudes, where halogen catalyzed ozone loss cycles dominate (Figure. 16), and halogen cycles are slowed down there as $\left[\mathrm{NO}_{\mathrm{x}}\right]$ increases. The overall effect of $\mathrm{B} 1 \mathrm{H}_{2}$-ICE scenario is minimal on stratospheric ozone column $(+0.04 \%)$. However, the total column ozone, the amount of ozone overhead, would still be $0.06 \%$ less than that in the B1 Baseline scenario since tropospheric ozone is reduced.

\section{Comparison with other studies}

There have been several studies of a hydrogen society's impact on the atmosphere. Tromp et al. [2003] used the Caltech/JPL 2-D CTM to study the impact of quadrupling atmospheric $\mathrm{H}_{2}$ concentration on the stratosphere. They did not consider the changes of related emissions $\left(\mathrm{CO}, \mathrm{NO}_{\mathrm{x}}, \mathrm{NMVOCs}\right)$ associated with the replacement of fossil fuel with hydrogen technology. They found major ozone loss of up to $8 \%$ during polar spring, however, their modeling results did not capture subtle ozone features at non-polar latitudes, while better representation of dynamical and transport processes in our threedimensional modeling work allowed us to do so. Despite of these major differences, we may take a comparison of projected stratospheric water vapor concentration with Tromp et al. They predicted 0 35\% water vapor increase due to $300 \%$ increase of $\mathrm{H}_{2}$ concentration. Our study shows about $30 \%$ increase of $\mathrm{H}_{2}$ mixing ratio would result in $0 \sim 5 \%$ increase in stratospheric $\mathrm{H}_{2} \mathrm{O}$. These results are in general agreement if we scale the concentration change.

Tromp et al. [2003] predicted maximum column ozone change rather differently from our study: they predicted that maximum reduction occurs at poles during spring. This discrepancy may arise because their simulations were based on the current atmosphere, in which atmospheric $\mathrm{Cl}_{\mathrm{y}}$ and $\mathrm{Br}_{\mathrm{y}}\left(\mathrm{Cl}_{\mathrm{y}}\right.$ and $\mathrm{Br}_{\mathrm{y}}$ are important in ozone hole chemistry) burdens are still large, whereas our simulations are based on the 2050 atmosphere, in which $\left[\mathrm{Cl}_{\mathrm{y}}\right]$ and $\left[\mathrm{Br}_{\mathrm{y}}\right]$ are reduced as a consequence of the implementation of the Montreal Protocol.

Taking into consideration of associated changes in $\mathrm{CO}, \mathrm{NO}_{\mathrm{x}}, \mathrm{NMVOCs}$ emissions when using $\mathrm{H}_{2}$ fuel and using a 2-D model, Warwick et al. [2004] found no significant change 
in stratospheric ozone (it slightly increased by $\sim 0.1 \%$ according to their study). What is worth noting is that another experiment in the same paper showed four-fold increase in atmospheric $\mathrm{H}_{2}$ concentration would increase stratospheric ozone. Warwick et al. attributed this to that in their model $\mathrm{H}_{2}$ is not completely converted to water vapor in the stratosphere. They found up to $20 \%$ stratospheric water vapor increase if $\mathrm{H}_{2}$ concentration quadrupled. This number is significantly lower than that found by Tromp et al. [2003].

\section{Conclusions}

In this study possible impact of a future $\mathrm{H}_{2}$-based road transportation sector on stratospheric composition and chemistry is investigated by modeling simulations of the 2050 atmosphere based on different assumed scenarios on emissions, in which, to bracket the possible lower and higher ends, the world is projected to evolve along either a fossil fuel intensive (A1FI) pathway or a service and information intensive (B1) pathway, and $\mathrm{H}_{2}$-based road transportation sector is assumed to be implemented with two different technological choices: $\mathrm{H}_{2}$ fuel cell and $\mathrm{H}_{2}$ internal combustion engine.

The modeling studies suggest that future implementation of an $\mathrm{H}_{2}$-based road transportation sector would perturb stratospheric chemistry, by means of affecting catalytic ozone destruction cycles involving $\mathrm{O}_{\mathrm{x}}, \mathrm{HO}_{\mathrm{x}}, \mathrm{NO}_{\mathrm{x}}, \mathrm{ClO}_{\mathrm{x}}$ and $\mathrm{BrO}_{\mathrm{x}}$. The magnitude of the impact depends on the future growth path as well as the $\mathrm{H}_{2}$ utilization technology adopted. The overall impact ranges from a $0.54 \%$ decrease $\left(\mathrm{A} 1 \mathrm{FI} \mathrm{H} \mathrm{H}_{2}-\mathrm{FC}\right)$ to a very slight increase $\left(0.04 \%, \mathrm{~B} 1 \mathrm{H}_{2}\right.$-ICE), depending on different scenarios and technological options, on a global mean total column ozone basis. The overall effect on stratospheric column ozone is considerable for the A1FI scenarios $\left(-0.54 \%\right.$ for $\mathrm{H}_{2}-\mathrm{FC}$ and $-0.23 \%$ for $\left.\mathrm{H}_{2}-\mathrm{ICE}\right)$ and for the $\mathrm{B} 1 \mathrm{H}_{2}-\mathrm{FC}$ scenario $(-0.20 \%)$. The largest relative reduction of ozone concentration takes place in the lower stratosphere where impact from the underlying troposphere is prominent. In the middle stratosphere ozone concentration slightly increases. At higher altitude it either slightly decreases or slightly increases depending on scenarios, but this change has little impact on column ozone since ozone at this level only takes up a few percent in terms of column ozone, due to the low ozone number concentration there. It is important to note that in developing the $\mathrm{H}_{2}$ emissions 
our assumptions were chosen to represent the maximum possible impact and thus these estimates likely represent the maximum possible ozone loss.

Our modeling studies suggest that the impact of an $\mathrm{H}_{2}$-based road transportation sector on stratospheric ozone depends on technological options. The combined effect of changes in catalytic cycles would result in more ozone loss for the $\mathrm{H}_{2}-\mathrm{FC}$ scenarios than in the $\mathrm{H}_{2}$ ICE scenarios. Meanwhile, the impact on stratospheric ozone depends also on which scenario the world would evolve along in the future. Our studies suggest that with the same technological option, there would be less impact on stratospheric ozone if the world evolves along B1 scenario than A1FI.

It is also worth noting that even though an $\mathrm{H}_{2}$-based road transportation sector is likely to decrease stratospheric ozone, this reducing effect is projected to be less than the ozone recovery effect due to removal of ozone depleting substances from the atmosphere as of 2050. In terms of total column ozone, there would be still $4 \% \sim 7 \%$ more ozone in the 2050 atmosphere with an $\mathrm{H}_{2}$-based road transportation sector than that in today's atmosphere. Therefore, the ozone reduction due to an $\mathrm{H}_{2}$-based road transportation sector might not constitute a major concern on increased UV radiation at the surface in 2050. 


\section{References:}

1. Chapman, S., A theory of upper atmospheric ozone, Mem. Roy. Meteorol. Soc. 3, 103-125, 1930.

2. Garcia, R. R., D. R. Marsh, D. E. Kinnison, B. A. Boville, and F. Sassi, Simulation of secular trends in the middle atmosphere, 1950-2003, J. Geophys. Res., 112, D09301, doi:10.1029/2006JD007485, 2007.

3. IPCC, Climate Change 2001, The Scientific Basis. Contribution of Working Group 1 to the Third Assessment Report of the IPCC, Cambridge University Press, Cambridge, UK and New York, USA, 2001.

4. Kinnison, D. E., G. P. Brasseur, S. Walters, et al., Sensitivity of chemical tracers to meteorological parameters in the MOZART-3 chemical transport model, $J$. Geophys. Res., 112, D20302, doi:10.1029/2006JD007879, 2007.

5. Ko, M. K. W., M. B. McElroy, D. K. Weisenstein, and N. D. Sze, Lightning: A possible source of stratosphere odd nitrogen, J. Geophys. Res., 91, 5395-5404, 1986.

6. Lamarque, J.-F., D. E. Kinnison, P. G. Hess, and F. M. Vitt, Simulated lower stratospheric trends between 1970 and 2005: Identifying the role of climate and composition changes, J. Geophys. Res., 113, D12301, doi:10.1029/2007JD009277, 2008.

7. Lin, J.T., K.O. Patten, K. Hayhoe, X.-Z. Liang and D.J. Wuebbles, Effects of future climate and biogenic emissions changes on surface ozone over the United States and China, Journal of Applied Meteorology and Climatology 47 (7), pp. 1888-1909, 2008.

8. Liu, C., Y. Liu, Z. Cai, S. Gao, D. Lu, and E. Kyrola, A Madden-Julian Oscillation-triggered record ozone minimum over the Tibetan Plateau in December 2003 and its association with stratospheric "'low-ozone pockets," Geophys. Res. Lett., 36, L15830, doi:10.1029/2009GL039025, 2009.

9. Liu, Y., C. X. Liu, H. P. Wang, X. X. Tie, S. T. Gao, D. Kinnison, and G. Brasseur, Atmospheric tracers during the 2003-2004 stratospheric warming event and impact of ozone intrusions in the troposphere, Atmospheric Chemistry And Physics, Volume 9, Issue 6, Pages: 2157-2170, 2009. 
10. McElroy, M. B., R. J. Salawitch and K. Minschwaner, The changing stratosphere. Planet. Space. Sci., 40:373-401, 1992.

11. Minschwaner, K., R. J. Salawitch, and M. B. McElroy, Absorption of Solar Radiation by $\mathrm{O}_{2}$ : Implications for $\mathrm{O}_{3}$ and Lifetimes of $\mathrm{N}_{2} \mathrm{O}, \mathrm{CFCl}_{3}$, and $\mathrm{CF}_{2} \mathrm{Cl}_{2}, J$. Geophys. Res., 98(D6), 10, 543-10, 561, 1993.

12. Murphy, D. M., D. W. Fahey, M. H. Proffitt, S. C. Liu, K. R. Chan, C. S. Eubank, S. R. Kawa, and K. K. Kelly, Reactive Nitrogen and Its Correlation With Ozone in the Lower Stratosphere and Upper Troposphere, J. Geophys. Res., 98(D5), 8751-8773, 1993.

13. Nevison, C. D., S. Solomon, and R. S. Gao (1999), Buffering interactions in the modeled response of stratospheric $\mathrm{O}_{3}$ to increased $\mathrm{NO}_{x}$ and $\mathrm{HO}_{x}, J$. Geophys. Res., 104(D3), 3741-3754, doi:10.1029/1998JD100018.

14. Newman, P. A., E. R. Nash, S. R. Kawa, S. A. Montzka, and S. M. Schauffler (2006), When will the Antarctic ozone hole recover?, Geophys. Res. Lett., 33, L12814, doi:10.1029/2005GL025232.

15. Ordonez, C., N. Elguindi, O. Stein, et al., Global model simulations of air pollution during the 2003 European heat wave, Atmospheric Chemistry and Physics, Volume 10, Issue 2, Pages 789-815, 2010.

16. Park, M., W. J. Randel, L. K. Emmons, and N. J. Livesey, Transport pathways of carbon monoxide in the Asian summer monsoon diagnosed from Model of Ozone and Related Tracers (MOZART), J. Geophys. Res., 114, D08303, doi:10.1029/2008JD010621, 2009.

17. Seinfeld, J. H. and S. N. Pandis, Atmospheric Chemistry and Physics: From Air Pollution to Climate Change, 1997.

18. Tromp, T., R. Shia, M. Allen, J. Eiler, and Y. Yung, Potential environmental impact of a hydrogen economy on the stratosphere. Science 300, 1740-1742, 2003.

19. Warwick, N. J., S. Bekki, E. G. Nisbet, and J. A. Pyle, Impact of a hydrogen economy on the stratosphere and troposphere studied in a 2-D model, Geophys. Res. Lett., 31, L05107, doi:10.1029/2003GL019224, 2004.

20. World Meteorological Organization. Scientific Assessment of Ozone Depletion: 2006, Geneva, 2006. 
21. Youn, D., K.O. Patten, J.-T. Lin and D.J. Wuebbles, Explicit calculation of indirect global warming potentials for halons using atmospheric models, Atmospheric Chemistry And Physics, Volume 9, Issue 22, Pages: 8719-8733, 2009. 


\section{Appendix: A brief survey of stratospheric chemistry}

Ozone plays a central role in stratosphere chemistry. Local ozone concentrations are determined by photochemical production and loss as well as transport. In the stratosphere, ozone is produced through a series of reactions involving $\mathrm{O}_{2}$ in the presence of sunlight with wavelength less than $242 \mathrm{~nm}$ [e.g., Chapman, 1930]:

$$
\begin{aligned}
& \mathrm{O}_{2}+h v \rightarrow \mathrm{O}+\mathrm{O} \quad \lambda<242 \mathrm{~nm} \\
& \mathrm{O}+\mathrm{O}_{2}+\mathrm{M} \rightarrow \mathrm{O}_{3}+\mathrm{M} \\
& \mathrm{O}_{3}+h v \rightarrow \mathrm{O}_{2}+\mathrm{O} \\
& \mathrm{O}_{3}+\mathrm{O} \rightarrow 2 \mathrm{O}_{2}
\end{aligned}
$$

The key step in this sequence is generation of oxygen atoms formed when oxygen molecules are photochemically dissociated into oxygen atoms (reaction 1). These oxygen atoms quickly combine with oxygen molecules in the presence of a third body $(\mathrm{M}$, typically $\mathrm{N}_{2}$ or $\mathrm{O}_{2}$ ) to form ozone (reaction 2). The rates of reactions (2) and (3) are substantially larger than those of reactions ( 1 and 4), thus $\mathrm{O}$ and $\mathrm{O}_{3}$ are quickly interconverting. Because of this quick cycling $\mathrm{O}$ and $\mathrm{O}_{3}$ are collectively referred to as odd oxygen $\left(\mathrm{O}_{\mathrm{x}}\right)$, and ozone loss can be expressed as destruction of $\mathrm{O}_{\mathrm{x}}$.

Ozone (or $\mathrm{O}_{\mathrm{x}}$ ) is destroyed through several pathways including odd oxygen only chemistry and through catalytic ozone destruction cycles involving $\mathrm{NO}_{\mathrm{x}}, \mathrm{HO}_{\mathrm{x}}, \mathrm{ClO}_{\mathrm{x}}$, and $\mathrm{BrO}_{\mathrm{x}}$. Reaction (4) represents the ozone loss through oxygen only chemistry and together with reactions (1)-(3) make up the Chapman mechanism which laid the foundation of our current understanding of stratospheric ozone [e.g., Chapman, 1930; Seinfeld and Pandis, 2006]. A typical catalytic ozone destruction cycle involving $\mathrm{X}=\mathrm{NO}, \mathrm{OH}, \mathrm{H}, \mathrm{Cl}$, or $\mathrm{Br}$ may be written

$$
\begin{aligned}
& \mathrm{X}+\mathrm{O}_{3} \rightarrow \mathrm{XO}+\mathrm{O}_{2} \\
& \mathrm{XO}+\mathrm{O} \rightarrow \mathrm{X}+\mathrm{O}_{2} \\
& \text { Net: } \mathrm{O}+\mathrm{O}_{3} \rightarrow 2 \mathrm{O}_{2}
\end{aligned}
$$


During this cycle the $\mathrm{X}$ consumed in reaction (5) is regenerated in reaction (6) and available to repeat the cycle while two odd oxygens are destroyed in the cycle. Since it is regenerated, $X$ acts as a catalyst for ozone destruction. In the catalytic cycles there is typically fast cycling between reactions $\mathrm{X}$ and $\mathrm{XO}$ such that they are referred to as $\mathrm{XO}_{\mathrm{x}}$, e.g., $\mathrm{NO}_{\mathrm{x}}, \mathrm{HO}_{\mathrm{x}}, \mathrm{ClO}_{\mathrm{x}}, \mathrm{BrO}_{\mathrm{x}}$. $\left(\mathrm{HO}_{\mathrm{x}}\right.$ may be defined to include $\mathrm{H}, \mathrm{OH}$, and $\left.\mathrm{HO}_{2}\right)$. For $\mathrm{NO}_{\mathrm{x}}$ and $\mathrm{HO}_{\mathrm{x}}$ the $\mathrm{XO}_{2}$ reactions may also be important, e.g.,

$$
\begin{aligned}
& \mathrm{HO}_{2}+\mathrm{O}_{3} \rightarrow \mathrm{OH}+2 \mathrm{O}_{2} \\
& \mathrm{NO}_{2}+\mathrm{O}_{3} \rightarrow \mathrm{NO}_{3}+\mathrm{O}
\end{aligned}
$$

For $\mathrm{NO}_{\mathrm{x}}$ there is a competing reaction for $\mathrm{NO}_{2}$.

$$
\mathrm{NO}_{2}+h v \rightarrow \mathrm{NO}+\mathrm{O}
$$

Note that reactions (8) and (9) represent a null cycle in which no ozone is destroyed since the $\mathrm{O}$ quickly reacts via reaction (2) to reform $\mathrm{O}_{3}$.

The catalytic destruction cycles do not operate in isolation from each other but are coupled, for example

$$
\begin{aligned}
& \mathrm{BrO}+\mathrm{ClO} \rightarrow \mathrm{BrCl}+\mathrm{O}_{2} \\
& \mathrm{BrCl}+h v \rightarrow \mathrm{Br}+\mathrm{Cl} \\
& \mathrm{BrO}+\mathrm{ClO} \rightarrow \mathrm{ClOO}+\mathrm{Br} \\
& \mathrm{ClOO}+\mathrm{M} \rightarrow \mathrm{Cl}+\mathrm{O}_{2} \\
& \mathrm{HO}_{2}+\mathrm{NO} \rightarrow \mathrm{OH}+\mathrm{NO}_{2} \\
& \mathrm{XO}+\mathrm{HO}_{2} \rightarrow \mathrm{HOX}+\mathrm{O}_{2} \\
& \mathrm{HOX}+h v \rightarrow \mathrm{OH}+\mathrm{X}
\end{aligned}
$$

For $\mathrm{X}=\mathrm{Cl}$ or $\mathrm{Br}$ in reactions (15) and (16).

Ozone destruction through these catalytic cycles will continue until the catalyst is converted to a more stable form referred to as a reservoir species. A reservoir species may react to regenerate the catalyst or may leave the stratosphere via transport to the troposphere. The major reservoir species include $\mathrm{HNO}_{3}, \mathrm{HCl}$, and $\mathrm{ClONO}_{2}$ and are formed via reactions between the reactive families.

$$
\mathrm{OH}+\mathrm{NO}_{2}+\mathrm{M} \rightarrow \mathrm{HNO}_{3}+\mathrm{M}
$$




$$
\begin{aligned}
& \mathrm{Cl}+\mathrm{CH}_{4} \rightarrow \mathrm{HCl}+\mathrm{CH}_{3} \\
& \mathrm{ClO}+\mathrm{NO}_{2}+\mathrm{M} \rightarrow \mathrm{ClONO}_{2}
\end{aligned}
$$

The impact of coupling of the catalytic ozone destruction cycles is complex and depends on location in the stratosphere. In the mid latitude lower stratosphere overall catalytic ozone destruction is inversely correlated with $\mathrm{NO}_{\mathrm{x}}$ concentrations since the balance of the relative importance of reactions (7) and (14) depends on $\mathrm{NO}_{\mathrm{x}}$ concentrations as does the balance of reaction (6) with $\mathrm{X}=\mathrm{Cl}$ and reaction (19) [e.g., Wennberg et al., 1994; Seinfeld and Pandis, 2006].

The relative importance of each cycle varies with altitude in the stratosphere. $\mathrm{HO}_{\mathrm{x}}$ cycles are found to be the biggest mechanism of ozone destruction in the stratosphere below 22 $\mathrm{km}$ altitude [McElroy et al., 1992]. The $\mathrm{HO}_{\mathrm{x}}$ cycle (reactions 5 with $\mathrm{X}=\mathrm{OH}$ and 7) is found to be responsible for 30 50\% of ozone destruction in the lower stratosphere [Seinfeld and Pandis, 1997]. The $\mathrm{HO}_{\mathrm{x}}$ cycles dominate the loss of $\mathrm{O}_{\mathrm{x}}$ in the lower and upper stratosphere but has little impact in the mid-stratosphere $(\sim 35 \mathrm{~km})$ while the $\mathrm{NO}_{\mathrm{x}}$ cycle dominates loss in the middle stratosphere but has a relatively small direct impact in the lower and upper stratosphere (Figures $3 b, c$ and $4 b, c)$. In the upper stratosphere, the rate of ozone destruction resulting from $\mathrm{HO}_{\mathrm{x}}$ cycles is again more than that from $\mathrm{NO}_{\mathrm{x}}$ cycles [Minschwaner et al., 1993]. The most important catalytic cycle responsible for ozone destruction above $40 \mathrm{~km}$ consists of reactions (5) and (6), where in both reactions X represents $\mathrm{H}$. The increasing importance of the $\mathrm{HO}_{\mathrm{x}}$ cycle above with altitude comes from increasing $\mathrm{O}$ and $\mathrm{H}$ concentration with altitude. The impacts of the $\mathrm{O}_{\mathrm{x}}$ and halogen cycles are more uniform and play a less significant role throughout the stratosphere than either the $\mathrm{HO}_{\mathrm{x}}$ or $\mathrm{NO}_{\mathrm{x}}$ impact [e.g., Seinfeld and Pandis, 2006].

As mentioned in the introduction, a future hydrogen-based road transportation sector could perturb the stratospheric composition and chemistry by altering emissions of fossil fuel combustion byproducts and leaking $\mathrm{H}_{2}$ into the atmosphere. $\mathrm{H}_{2}$ 's atmospheric lifetime is around two years, which is longer than the time required for $\mathrm{H}_{2}$ to make its way to the stratosphere. Therefore a portion of $\mathrm{H}_{2}$ emitted at the surface will penetrate 
into the stratosphere, where it is oxidized and becomes a source of $\mathrm{HO}_{\mathrm{x}}$ (reactions 20 and 21). One $\mathrm{H}_{2}$ molecule can produce two $\mathrm{HO}_{\mathrm{x}}$ radicals via the following reactions

$$
\begin{aligned}
& \mathrm{O}\left({ }^{1} \mathrm{D}\right)+\mathrm{H}_{2} \rightarrow \mathrm{OH}+\mathrm{H} \\
& \mathrm{H}+\mathrm{O}_{2} \rightarrow \mathrm{HO}_{2}
\end{aligned}
$$

where $\mathrm{O}\left({ }^{1} \mathrm{D}\right)$ is the excited state of oxygen atom. In such a way, increased $\mathrm{H}_{2}$ concentration can lead to more $\mathrm{HO}_{\mathrm{x}}$ in the stratosphere (Figures. 10 and 11). 


\section{Tables and Figures}

Table 2. Annual-mean global emissions for key species.

\begin{tabular}{|c|c|c|c|c|}
\hline Species & $\mathrm{H}_{2}$ & $\mathrm{CO}$ & NO & NMVOCs \\
\hline Unit & $\mathrm{Tg} / \mathrm{yr}$ & $\mathrm{Tg} / \mathrm{yr}$ & $\mathrm{TgN} / \mathrm{yr}$ & $\mathrm{Tg} / \mathrm{yr}$ \\
\hline A1FI Baseline & 56.6 & 1844.7 & 94.3 & 600.9 \\
\hline A1FI $\mathrm{H}_{2}-\mathrm{FC}$ & 102.7 & 1383.4 & 67.2 & 518.5 \\
\hline $\mathrm{A} 1 \mathrm{FI} \mathrm{H}$-ICE & 102.7 & 1383.4 & 94.3 & 518.5 \\
\hline B1 Baseline & 32.4 & 1223.3 & 46.0 & 442.7 \\
\hline $\mathrm{B} 1 \mathrm{H}_{2}-\mathrm{FC}$ & 53.2 & 1107.1 & 34.8 & 408.5 \\
\hline $\mathrm{B} 1 \mathrm{H}_{2}-\mathrm{ICE}$ & 53.2 & 1107.1 & 46.0 & 408.5 \\
\hline
\end{tabular}




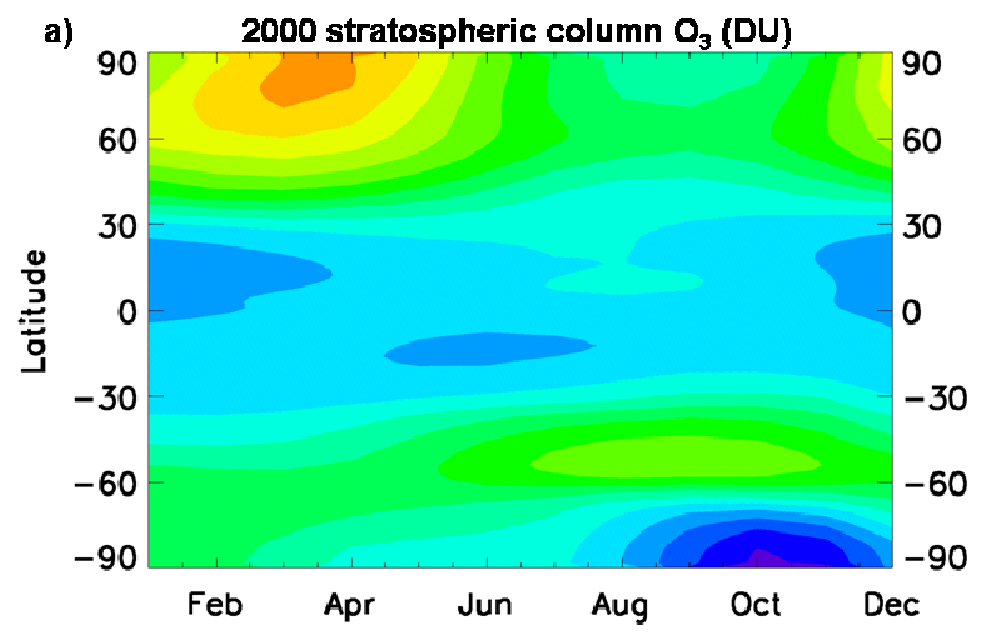

b) 2050 A1FI Baseline stratospheric column $\mathrm{O}_{3}$ (DU)
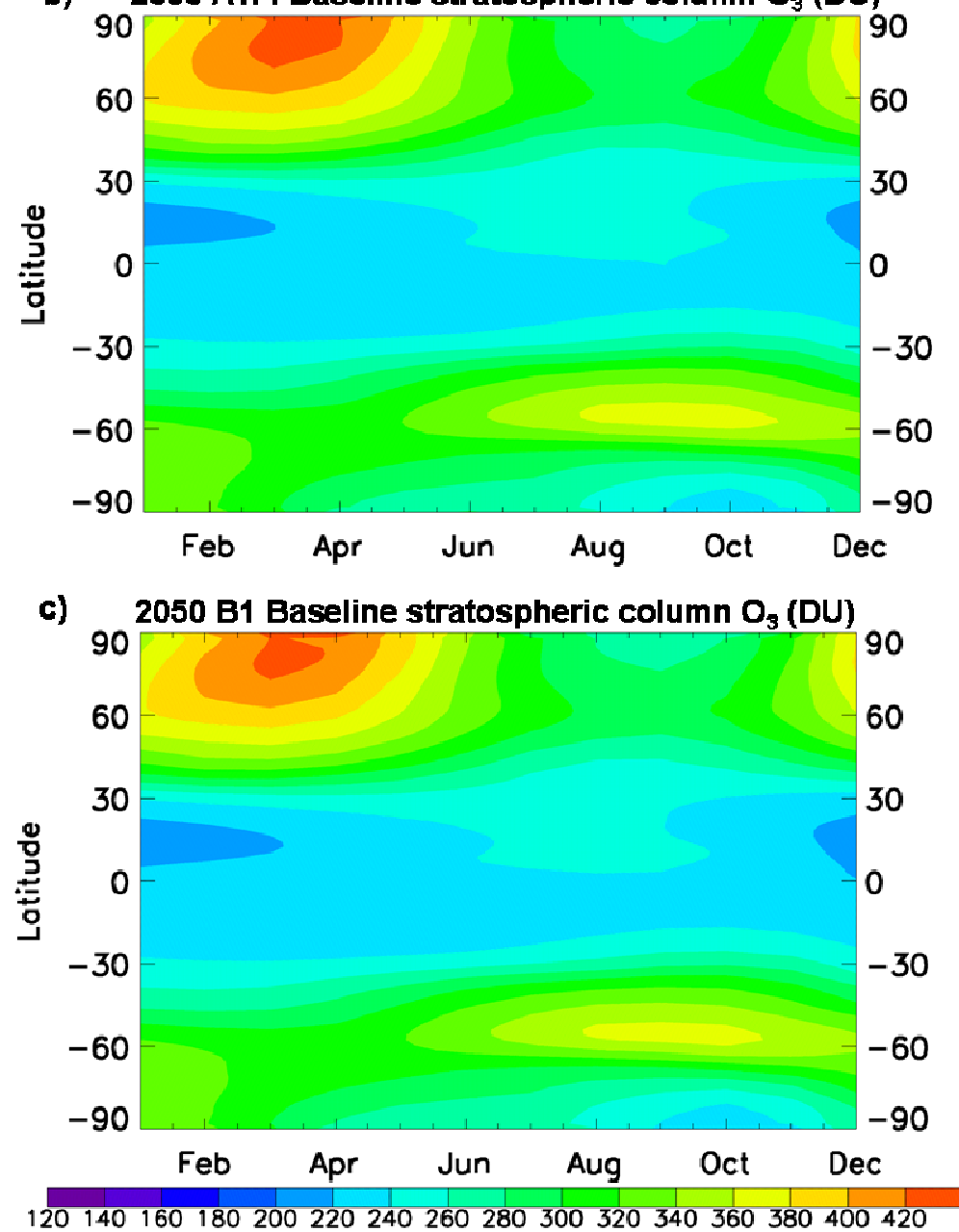

Figure 1. Simulated stratospheric column ozone as a function of latitude and year for (a) current (year 2000) atmosphere, (b) 2050 A1FI Baseline scenario and (c) 2050 B1 Baseline scenario. 

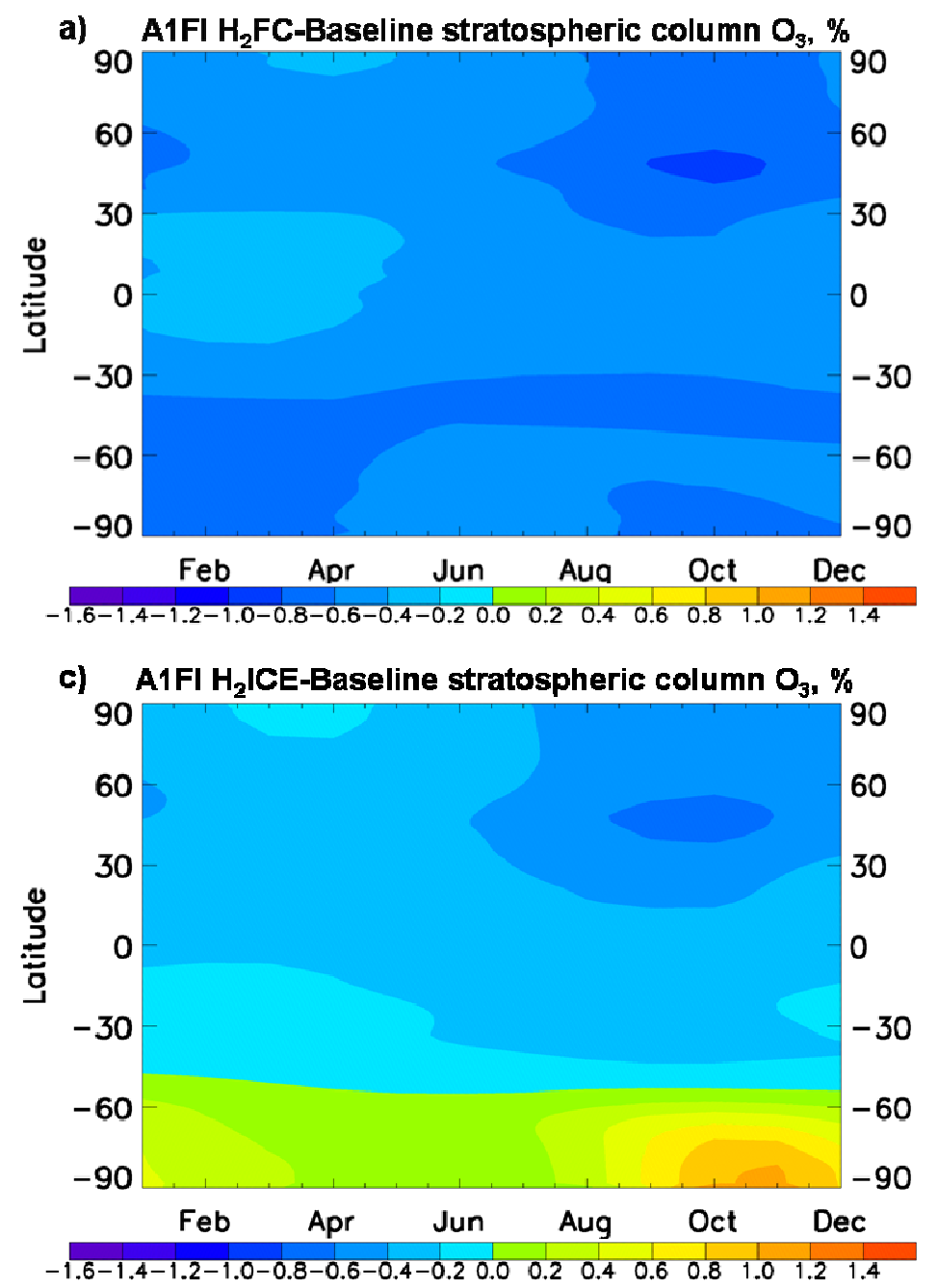

b) A1FI $\mathrm{H}_{2} \mathrm{FC}$-Baseline stratospheric column $\mathrm{O}_{3}$, DU

90
60
30
0
-30
-60
-90

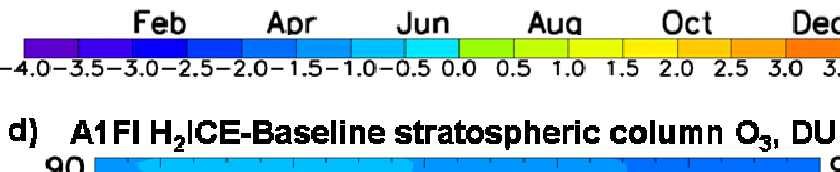

90
60
30
0
-30
-60
-90

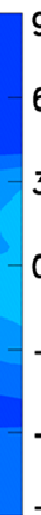
Feb Apr Jun Aug Oct Dec

Figure 2. Change of stratospheric column $\mathrm{O}_{3}$ in a year at different latitudes in $\mathrm{H}_{2}$ road transportation sectorscenarios relative to the A1FI Baseline scenario. (a): relative change (\%) for A1FI $\mathrm{H}_{2}$-FC; (b): absolute change (DU) for A1FI $\mathrm{H}_{2}$-FC; (c): relative change (\%) for A1FI $\mathrm{H}_{2}$-ICE; (d): absolute change (DU) for A1FI $\mathrm{H}_{2}$-ICE. 

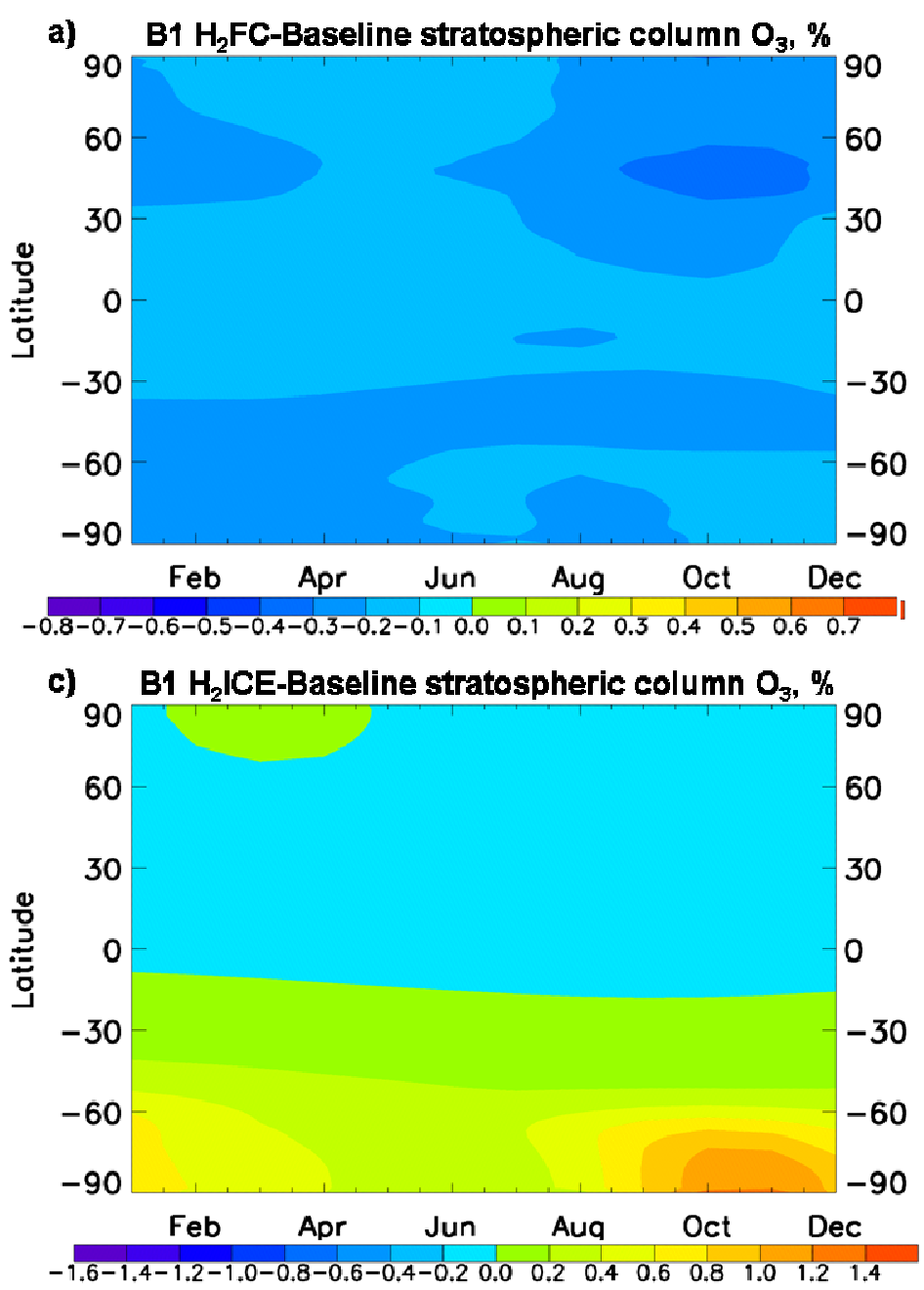
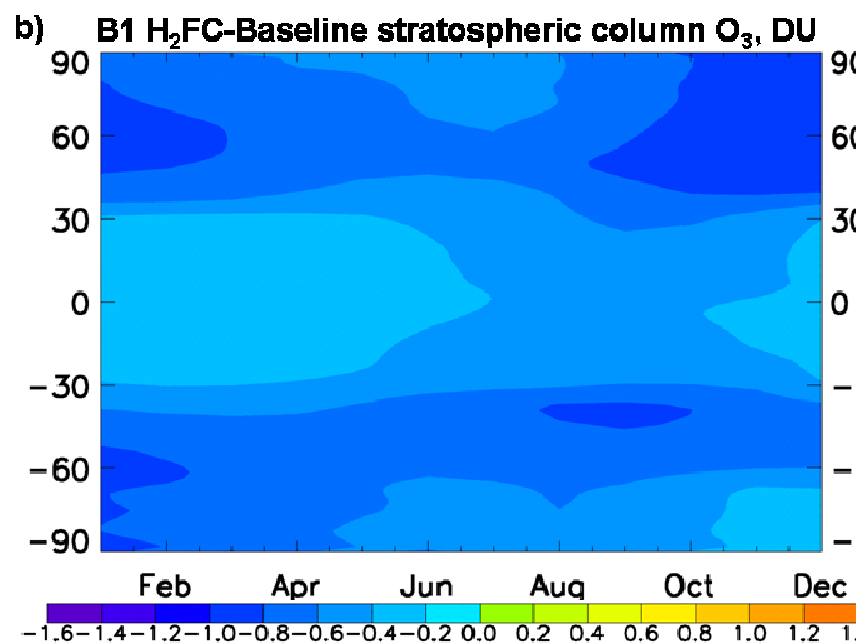

d) B1 $\mathrm{H}_{2} \mathrm{ICE}-B$ aseline stratospheric column $\mathrm{O}_{3}$, DU

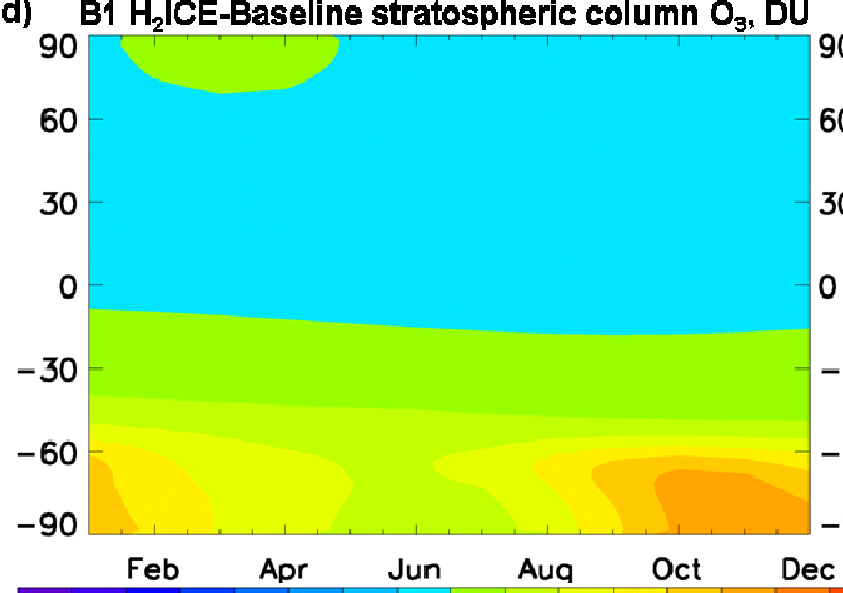

$\begin{array}{lllllllll}-4.0-3.5-3.0-2.5-2.0-1.5-1,0-0.5 & 0.0 & 0.5 & 1.0 & 1.5 & 2.0 & 2.5 & 3.0 & 3.5\end{array}$

Figure 3. Change of stratospheric column $\mathrm{O}_{3}$ in a year at different latitudes in $\mathrm{H}_{2}$ road transportation sector scenarios relative to the B1 Baseline scenario. (a): relative change (\%) for $\mathrm{B}_{1} \mathrm{H}_{2}-\mathrm{FC}$; (b): absolute change (DU) for $\mathrm{B} 1 \mathrm{H}_{2}$-FC; (c): relative change (\%) for $\mathrm{B} 1 \mathrm{H}_{2}$-ICE; (d): absolute change (DU) for B1 $\mathrm{H}_{2}$-ICE. 


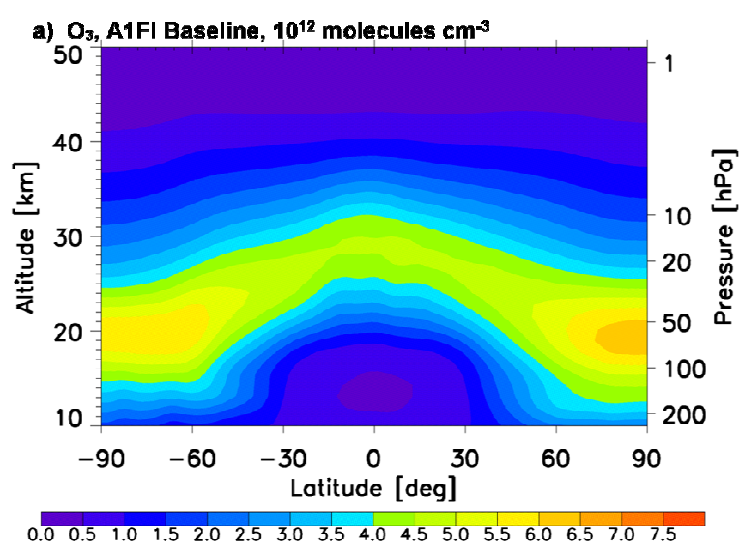

Figure 4. (a) $\mathrm{O}_{3}$ concentration for A1FI Baseline; (b) Relative change of $\mathrm{O}_{3}$ concentration in A1FI

$\mathrm{H}_{2}$-FC relative to Baseline; (c) Absolute change of $\mathrm{O}_{3}$ concentration in $\mathrm{A1FI} \mathrm{H}_{2}$-FC relative to Baseline; (d) Relative change of $\mathrm{O}_{3}$ concentration in A1FI $\mathrm{H}_{2}$-ICE relative to Baseline; (e) Absolute change of $\mathrm{O}_{3}$ concentration in A1FI $\mathrm{H}_{2}$-ICE relative to Baseline. All figures are zonal, annual-mean.
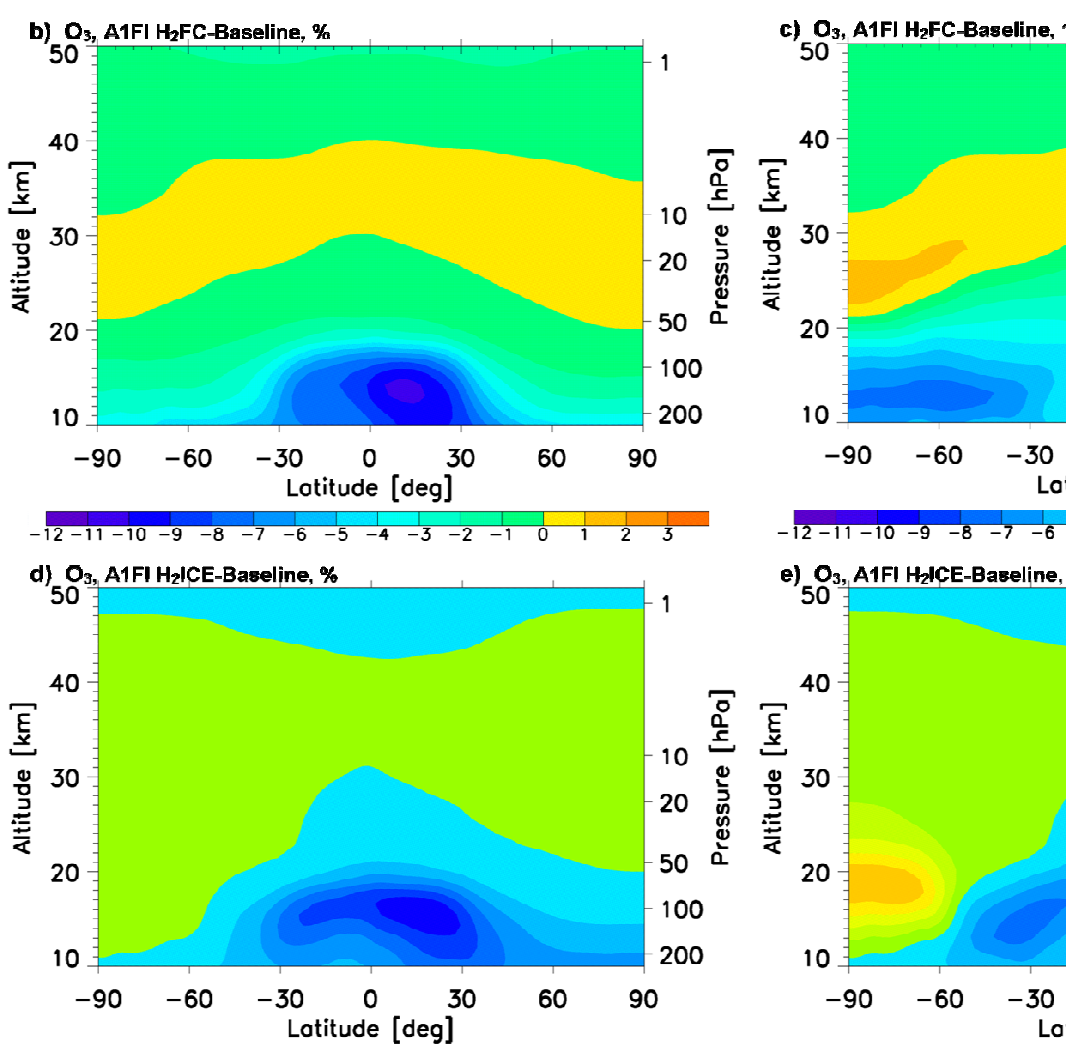

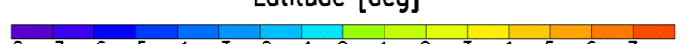

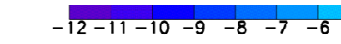

e) $\mathrm{O}_{3,}, \mathrm{~A} 1 \mathrm{FI} \mathrm{H}_{2} \mathrm{ICE}-B a s e l i n e$,

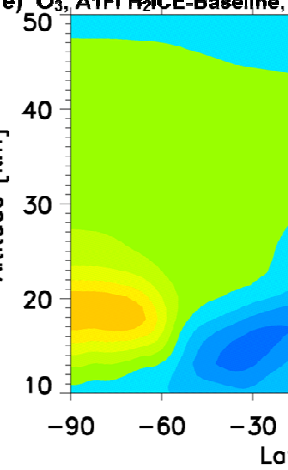

\begin{tabular}{lllllll}
\hline & -7 & -6 & -5 & -4 & -3 & -2
\end{tabular} 


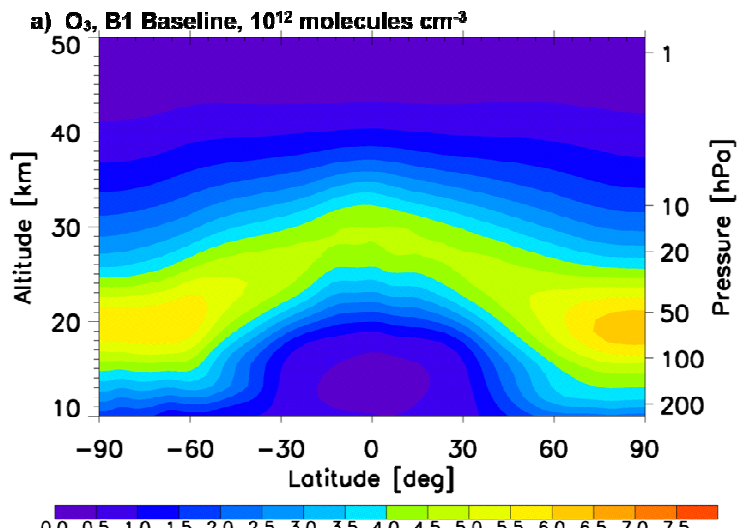

$\begin{array}{lllllllllllllllllll}0.0 & 0.5 & 1.0 & 1.5 & 2.0 & 2.5 & 3.0 & 3.5 & 4.0 & 4.5 & 5.0 & 5.5 & 6.0 & 6.5 & 7.0 & 7.5\end{array}$ b) $\mathrm{O}_{3}, \mathrm{B1} \mathrm{H}_{2} \mathrm{FC}$-Baseline, $\%$

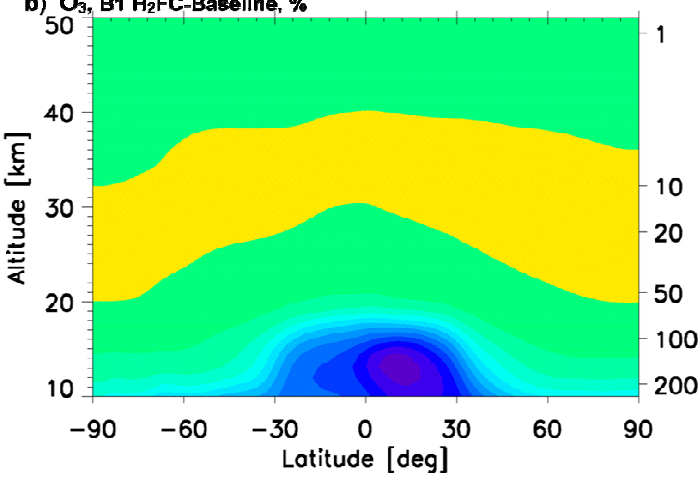

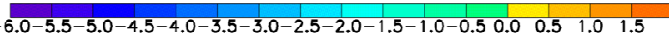
d) $\mathrm{O}_{3}, \mathrm{B1} \mathrm{H}_{2} \mid \mathrm{CE}-$-Baseline, $\%$

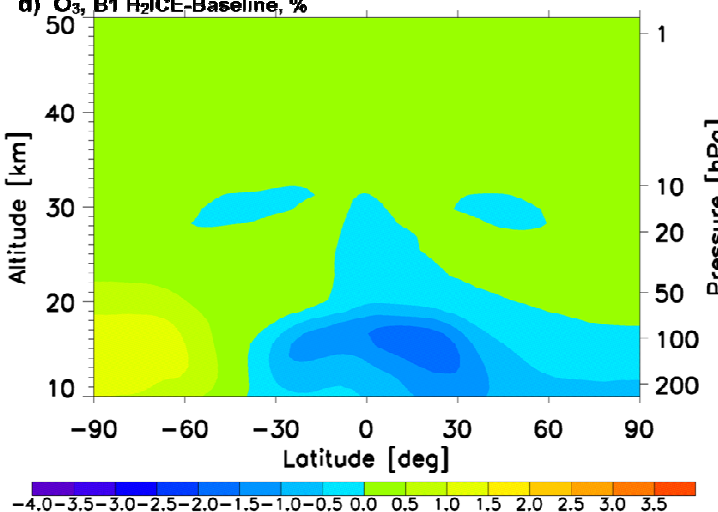

c) $\mathrm{O}_{3}, \mathrm{B1} \mathrm{H}_{2} \mathrm{FC}$-Basellne, 10

c) 50

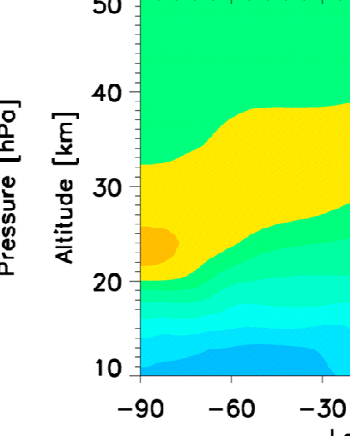

$-4 \cdot 0-3.5-3.0$ e) $\mathbf{O}_{3}$, B1 H ICE-Baseline, 10

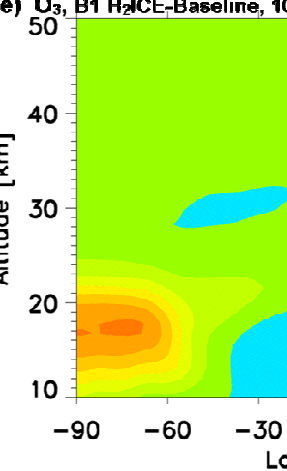

Figure 5. The same as in Figure.4 except that these figures are for the B1 scenarios. 

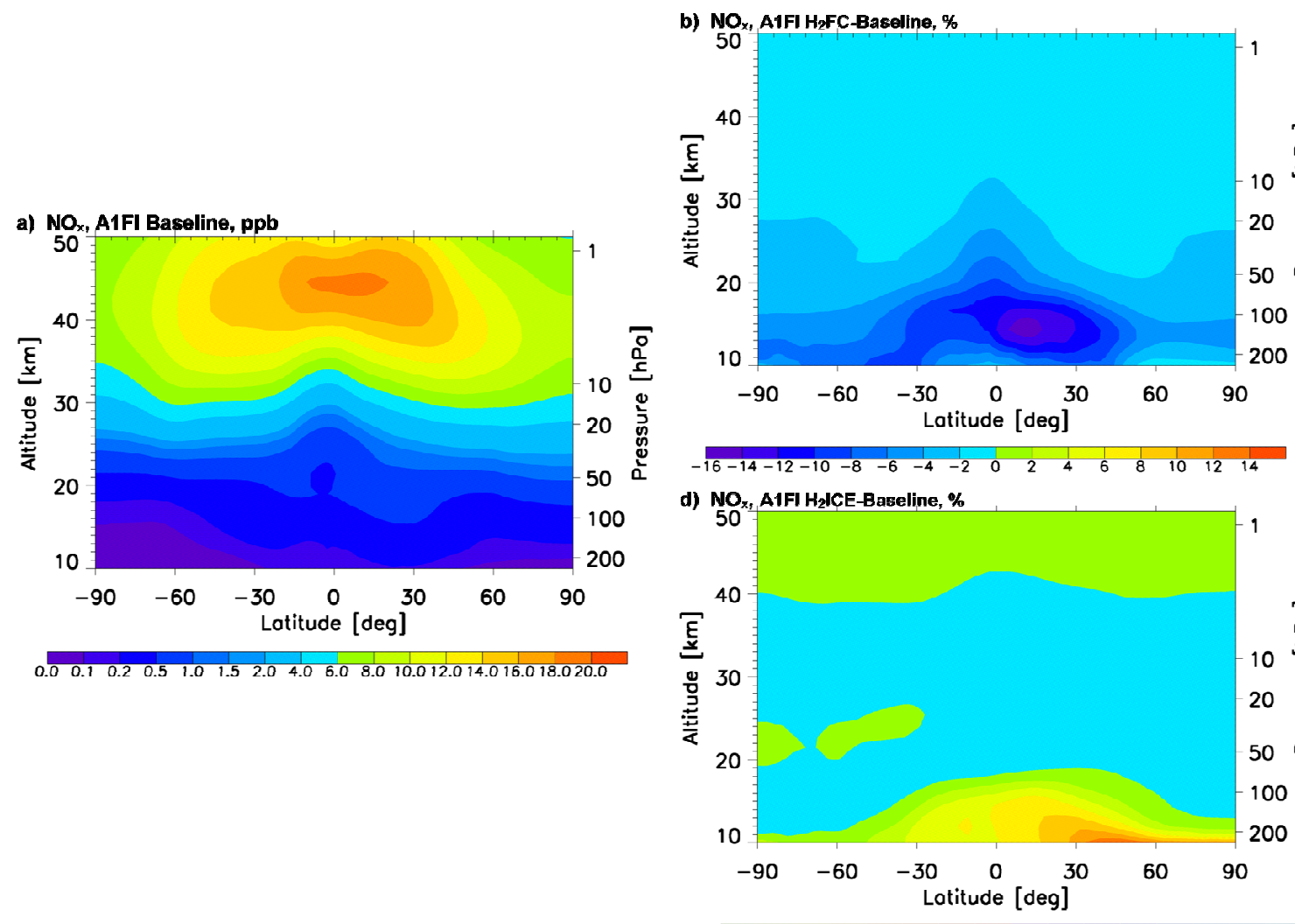

Figure 6. The same as in Figure 4 except that these figures are for $\mathrm{NO}_{\mathrm{x}}$.

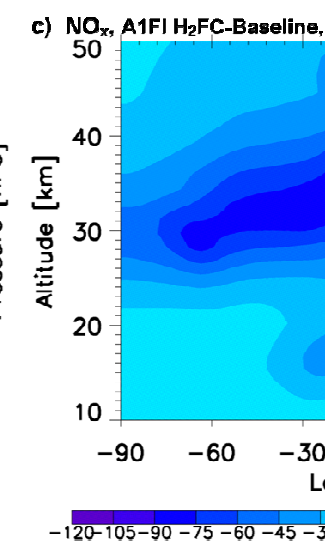

e) NO, A1FI H2ICE-Baselin

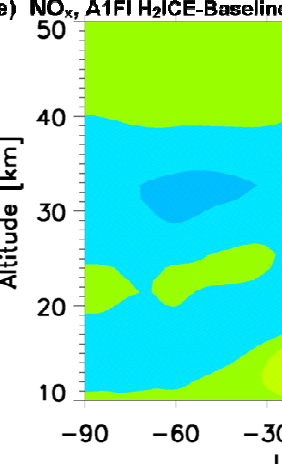




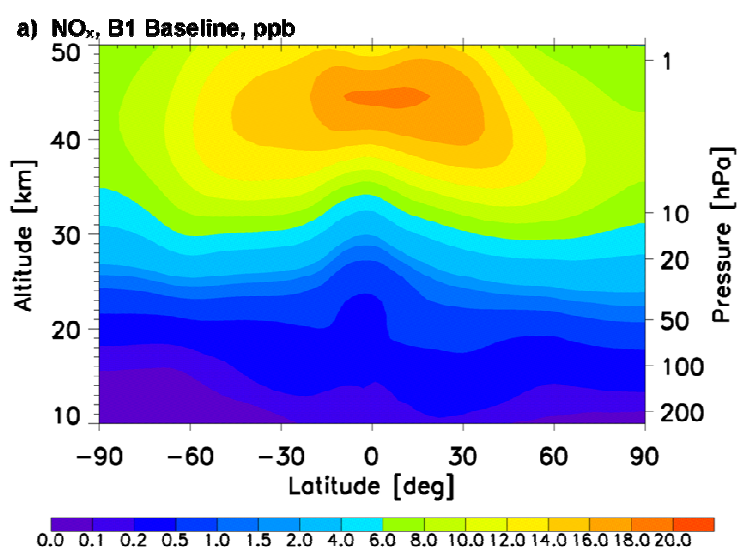

b) $\mathrm{NO}_{\mathbf{x}}, \mathrm{B1} \mathrm{H}_{2} \mathrm{FC}$-Baseline, \%

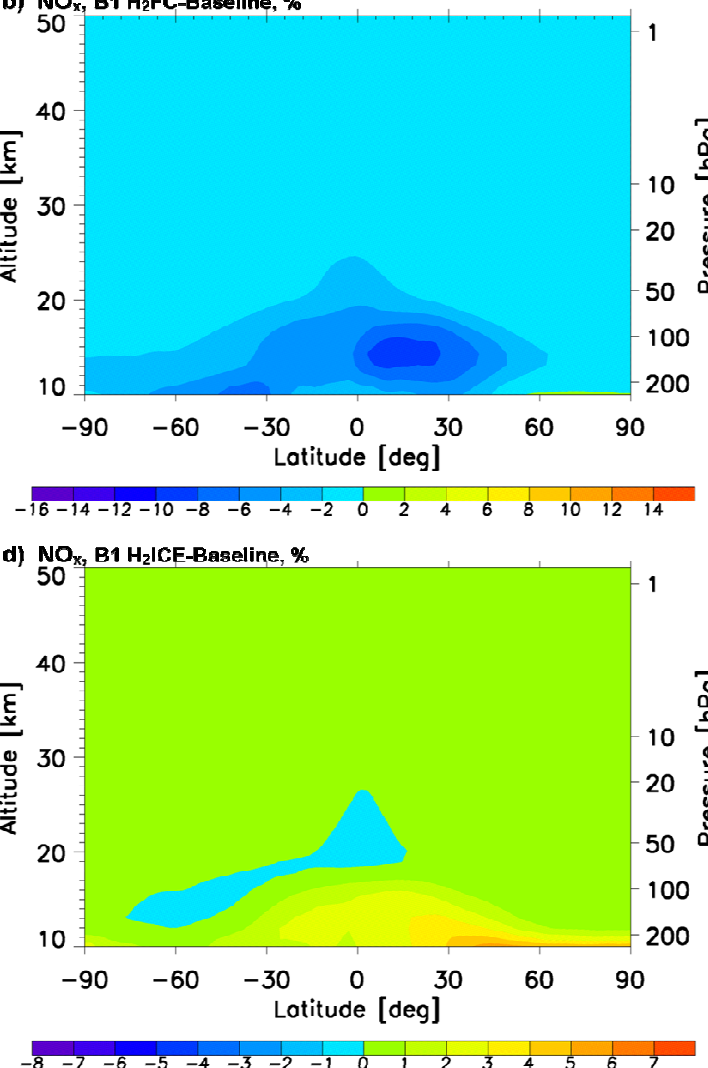

Figure 7. The same as in Figure 6 except that these figures are for the B1 scenarios. c) $\mathrm{NO}_{\mathrm{x}}, \mathrm{B1} \mathrm{H}_{2} \mathrm{FC}$-Baseline,

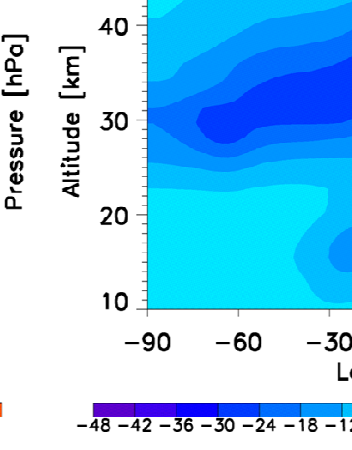

e) $\mathrm{NO}_{\mathbf{x}}$ B1 H $\mathrm{H}_{2}$ ICE-Bageline, 50

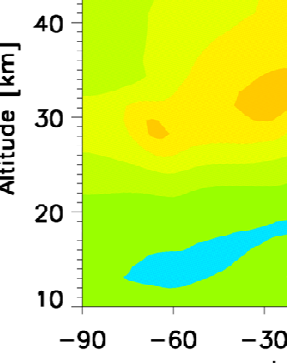

$-28-24-20-16-12-8$ 

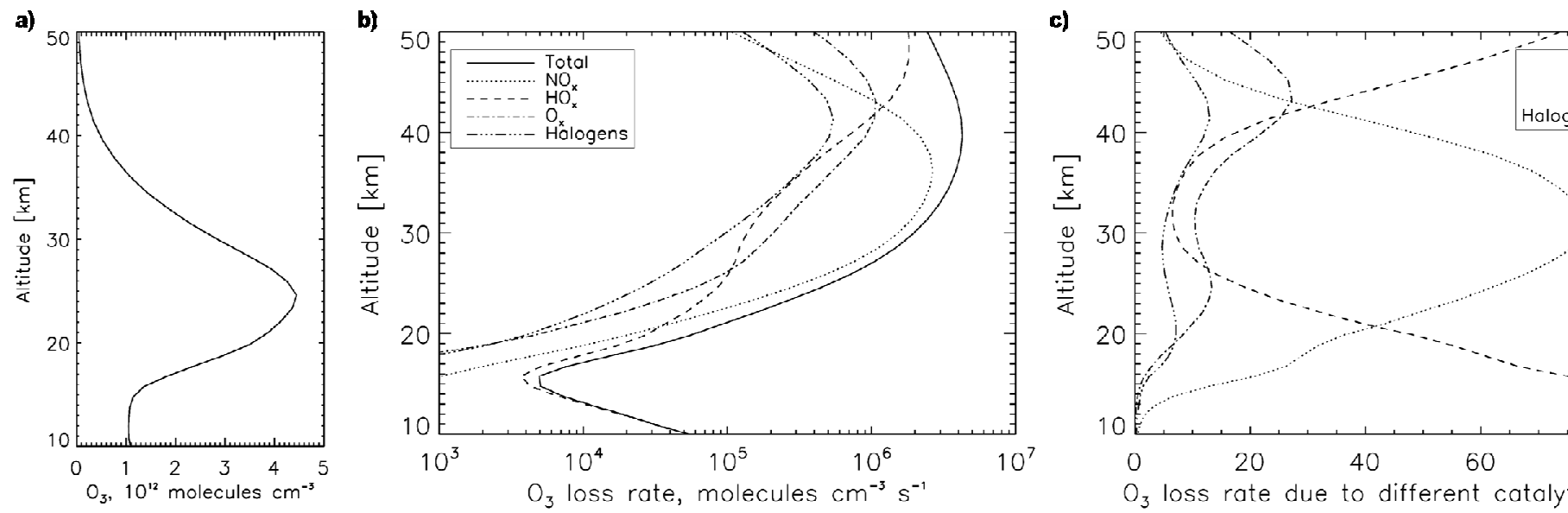

Figure 8. (a): Model calculated $\mathrm{O}_{3}$ profile;

(b): Model calculated contributions to total $\mathrm{O}_{3}$ loss rate by different catalytic cycles;

(c): profile of relative contributions (\%) by different catalytic cycles to the $\mathrm{O}_{3}$ loss rate.

All figures are daily averaged values for fall equinox at $35^{\circ} \mathrm{N}$ for the A1FI Baseline scenario. 

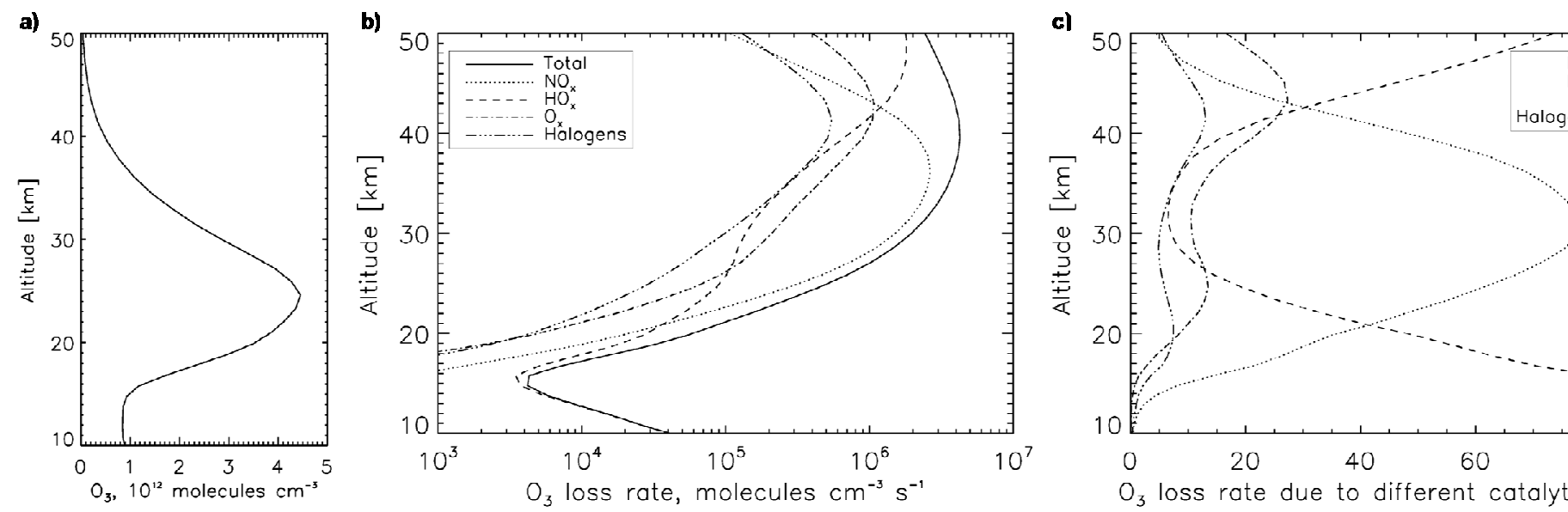

Figure 9. The same as in Figure 8 except that these figures are for the B1 scenarios. 
a) $\mathrm{HO}_{x}$, A1FI Baseline, $10^{8}$ molecules $\mathrm{cm}^{-3}$

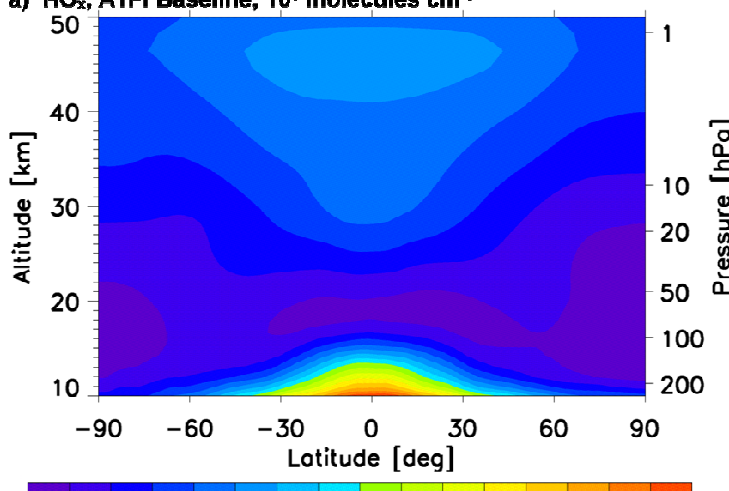

$\begin{array}{lllllllllllllll}3 & 6 & 9 & 12 & 15 & 18 & 21 & 24 & 27 & 30 & 33 & 36 & 39 & 42 & 45\end{array}$ b) $\mathrm{HO}_{\mathrm{x}}, \mathrm{A}$ 1FI $\mathrm{H}_{2} \mathrm{FC}$-Basellne, \%

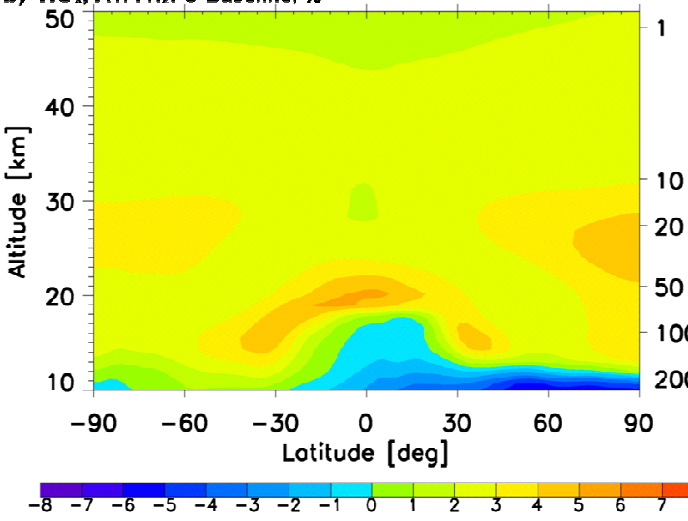

d) $\mathrm{HO}_{\mathrm{x}}$, A1FI H2ICE-Baseline, \%

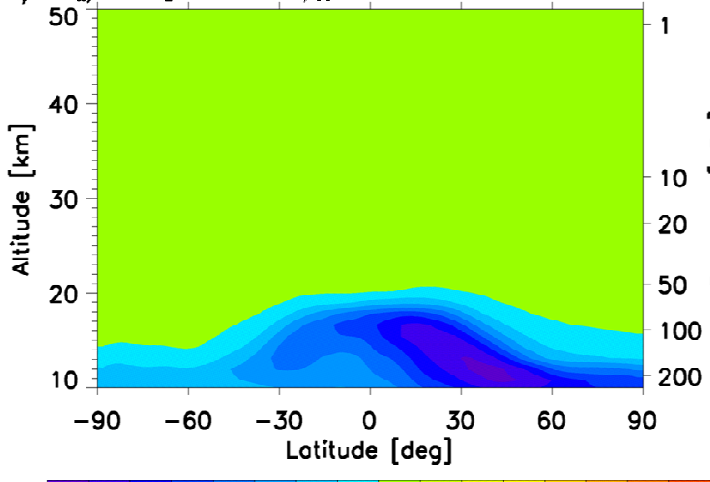

$\begin{array}{lllllllllllll}-16-14-12-10 & -8 & -6 & -4 & -2 & 0 & 2 & 4 & 6 & 8 & 10 & 12 & 14\end{array}$

Figure 10. The same as in Figure 4 except that these figures are for $\mathrm{HO}_{\mathrm{x}}$. c) $\mathrm{HO}_{x}$, A1FI H2FC-Baseline,$$
50
$$

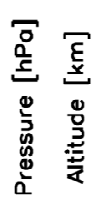

$40=$

30 =

20

20

10

$-90$

$1.6-1.4-1.2-1.0-0.8-0.6-0$

e) $\mathrm{HO}_{2}, \mathrm{~A} 1 \mathrm{FI} \mathrm{H}_{2} \mathrm{ICE}-\mathrm{Basellne}$

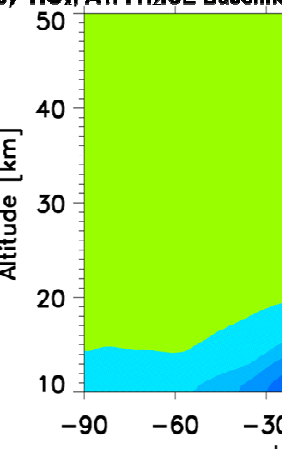

$-3.2-2.8-2.4-2.0-1.6-1.2-0$ 
a) $\mathrm{HO}_{\mathrm{x}}$, B1 Baseline, $10^{8}$ molecules $\mathrm{cm}^{3}$

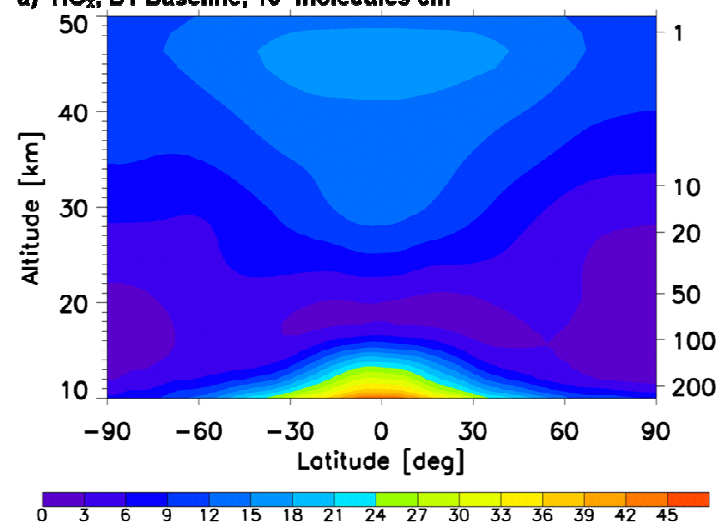

b) $\mathrm{HO}_{\mathrm{x},}$ B1 $\mathrm{H}_{2} \mathrm{FC}-$ Basellne, \%
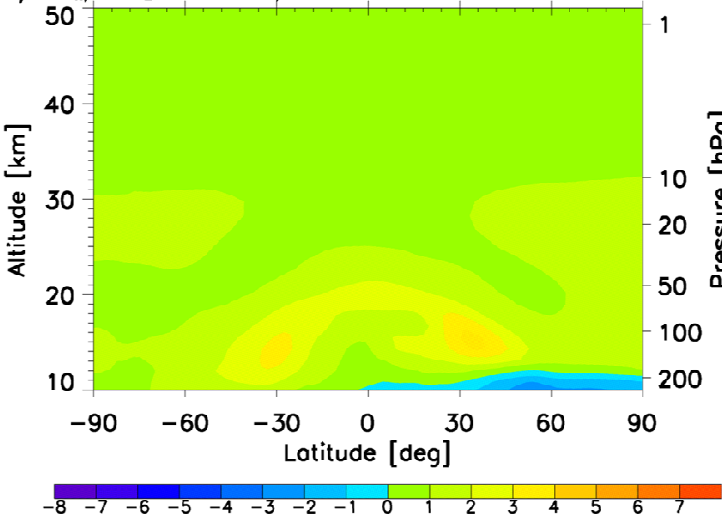

d) $\mathrm{HO}_{\mathrm{x}}, \mathrm{B1} \mathrm{H}_{2}$ ICE-Baseline, \%

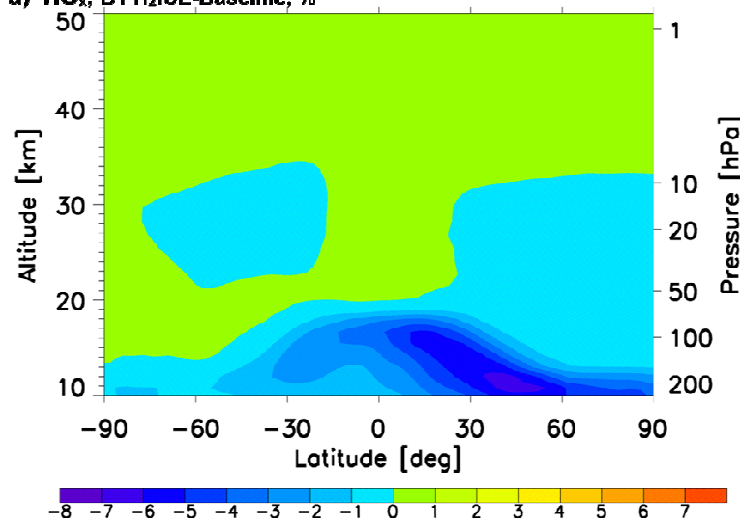

c) $\mathrm{HO}_{\mathrm{x}}, \mathrm{B} 1 \mathrm{H}_{2} \mathrm{FC}-\mathrm{Basellne}, 10$

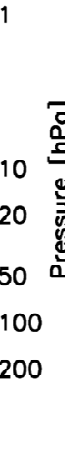

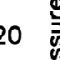

50

100

0

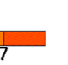

$-0.8-0.7-0.6-0.5-0.4-0.3-$

e) HOx, B1 HzlCE-Baseline, 1

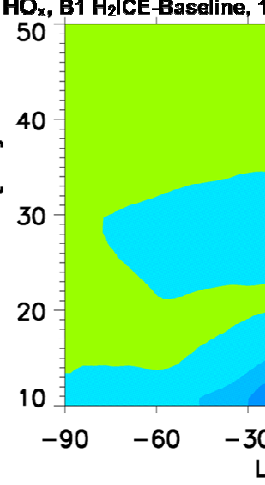

$-1.6-1.4-1.2-1.0-0.8-0.6-0$

Figure 11. The same as in Figure 10 except that these figures are for the B1 scenarios. 

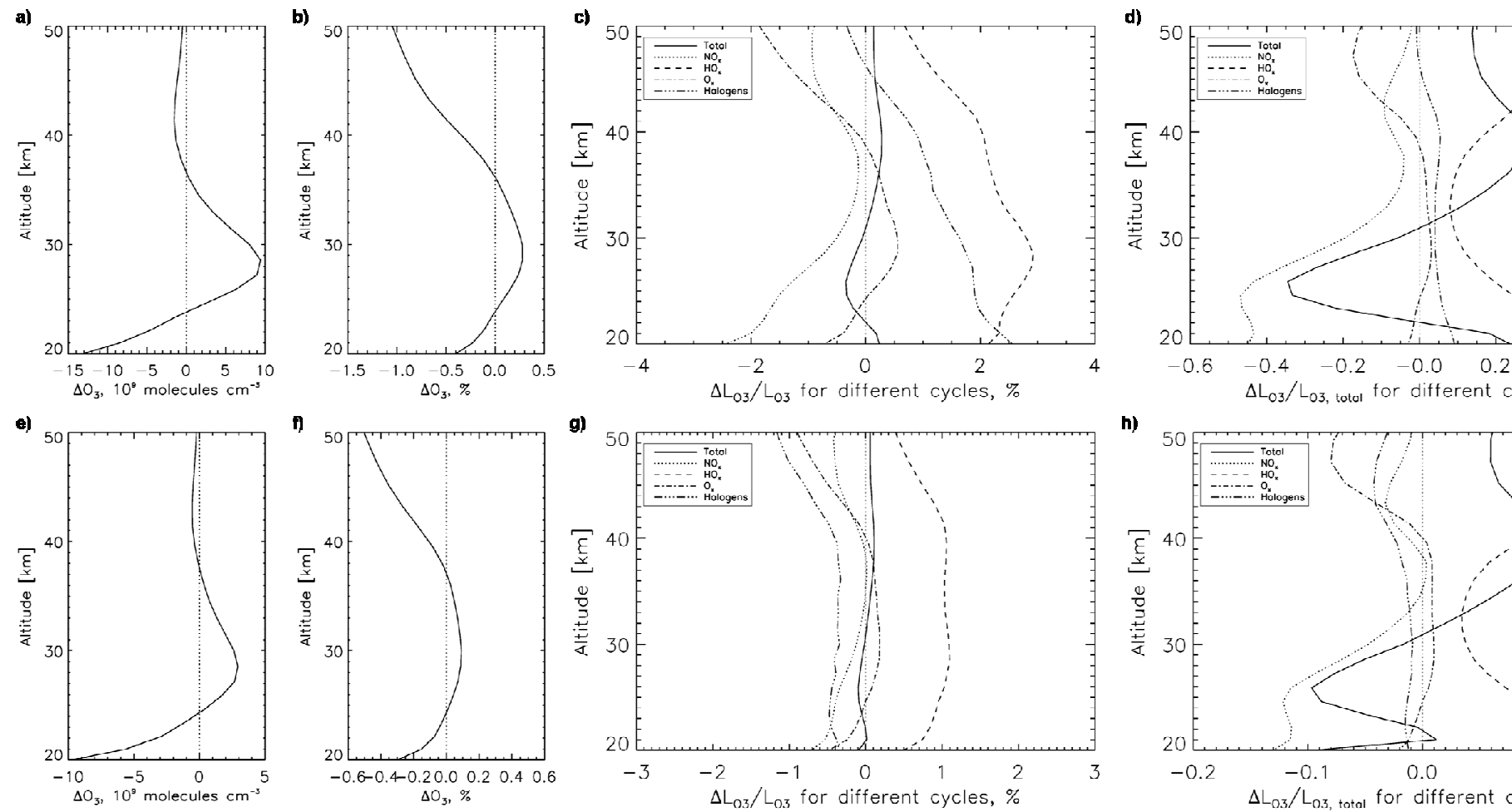

Figure 12. Changes of $\mathrm{O}_{3}$ profiles and contributions of different catalytic cycles to total $\mathrm{O}_{3}$ loss. The upper row of figures is for $\mathrm{H}_{2} \mathrm{FC}$-Baseline; lower row for $\mathrm{H}_{2} \mathrm{ICE}$-Baseline. (a) and (e): absolute $\mathrm{O}_{3}$ number concentration; (b) and (f): relative change (\%) in $\mathrm{O}_{3}$ number concentration; (c) and (g): change (\%) of different catalytic $\mathrm{O}_{3}$ destruction cycles compared to its contribution in Baseline; (d) and (h): change (\%) of different catalytic $\mathrm{O}_{3}$ destruction cycles compared to the total $\mathrm{O}_{3}$ loss rate in

Baseline. All figures are daily averaged values for fall equinox at $35^{\circ} \mathrm{N}$ for the A1FI scenarios. 

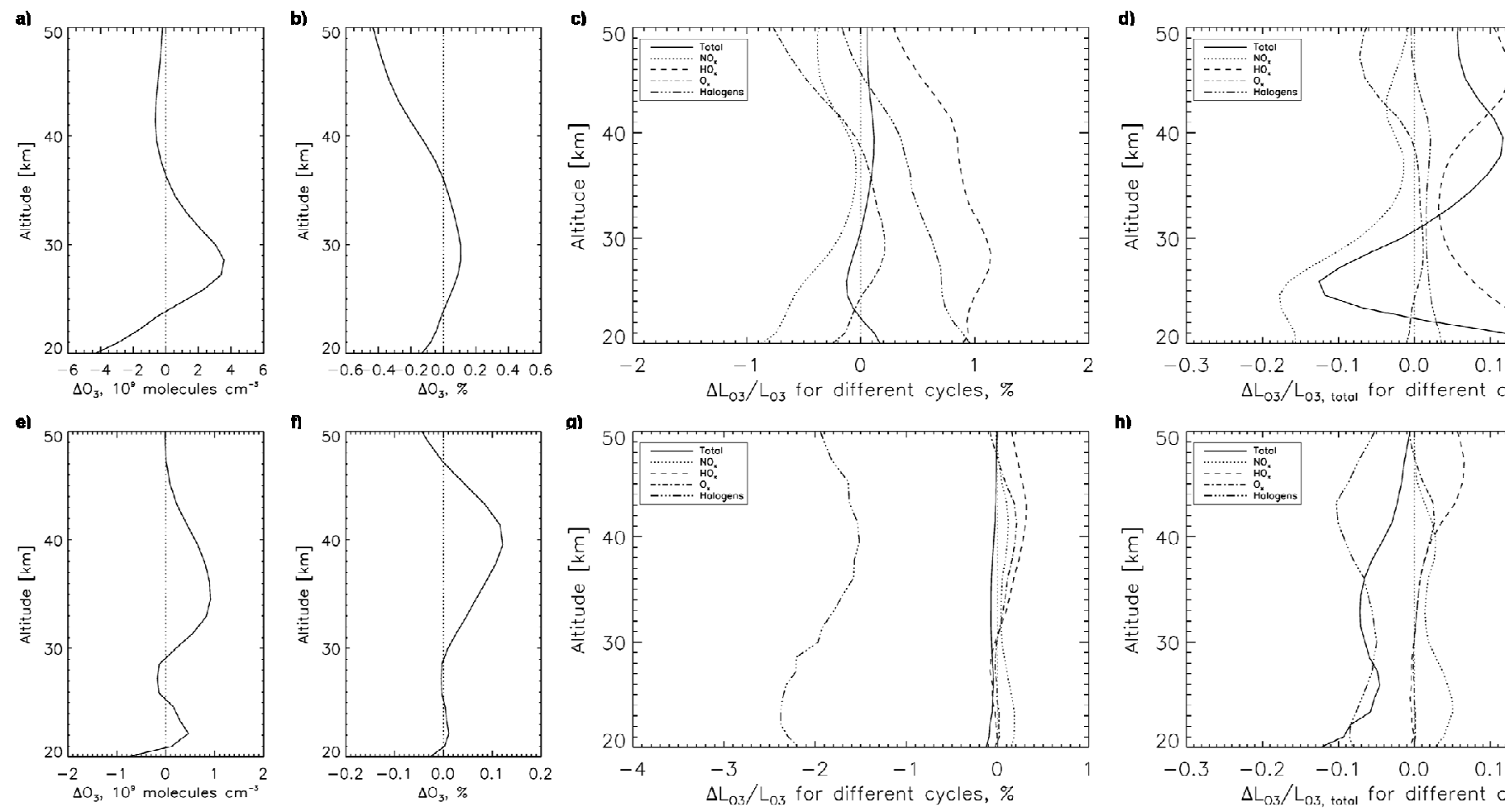

Figure 13. The same as in Figure 12 except that these figures are for the B1 scenarios. 


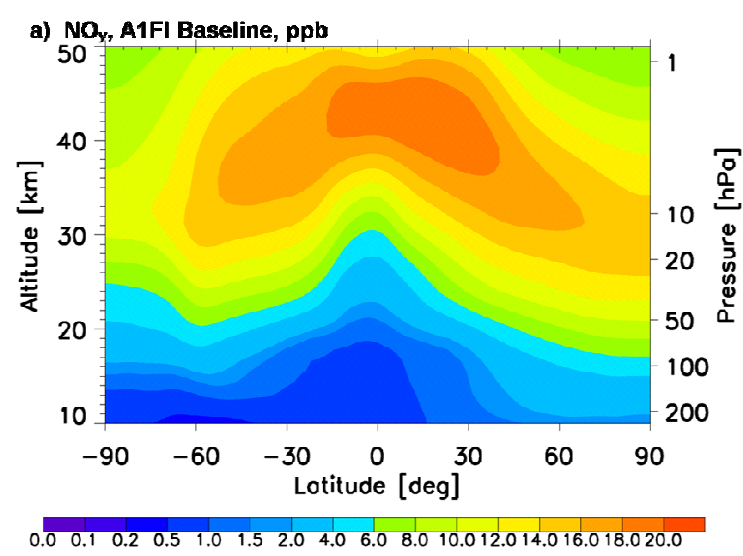

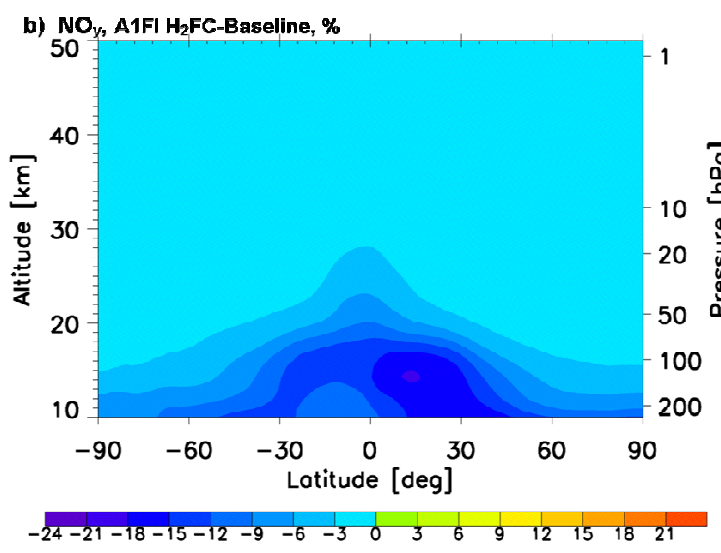

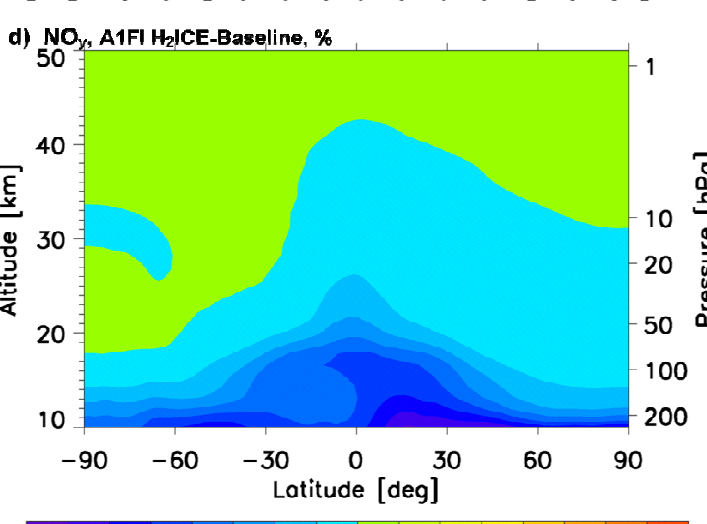

Figure 14. The same as in Figure 4 except that these figures are for $\mathrm{NO}_{\mathbf{y}}$. c) $\mathrm{NO}_{y}, \mathrm{A1FI} \mathrm{H}_{2} \mathrm{FC}-$-Basellne

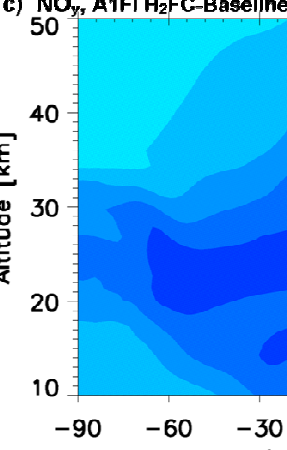

$-240-210-180-150-120-90-60$ e) $\mathrm{NO}_{5,}$ A.1FI HzlCE-Baselln

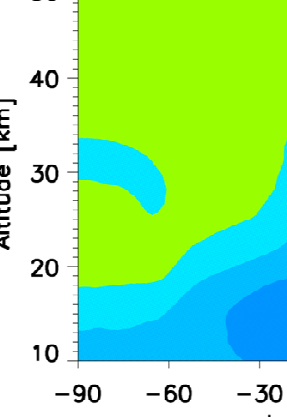

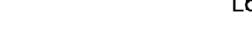

$-120-105-90-75-60-45-3$ 

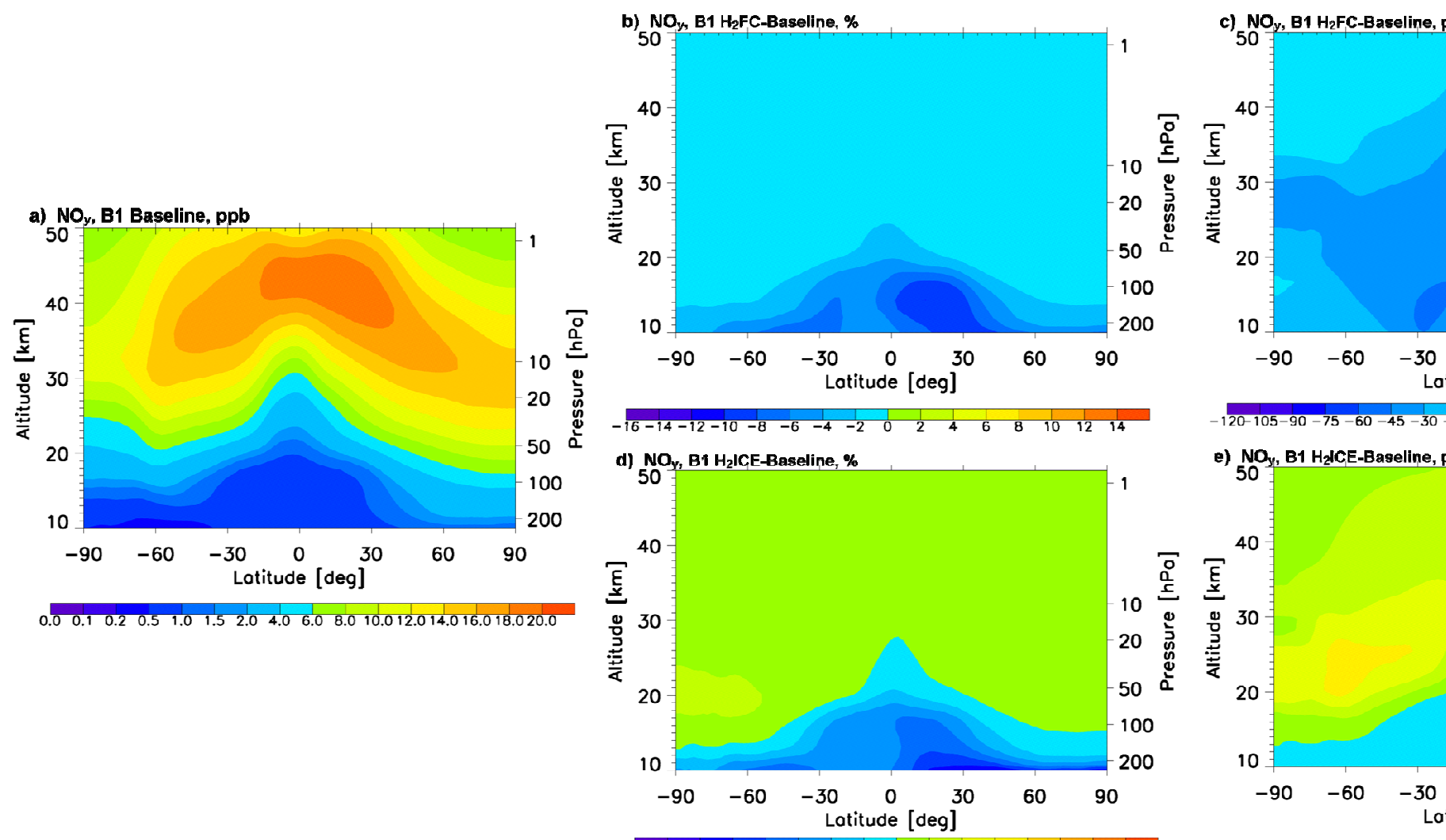

Figure 15. The same as in Figure 14 except that these figures are for the B1 scenarios. 


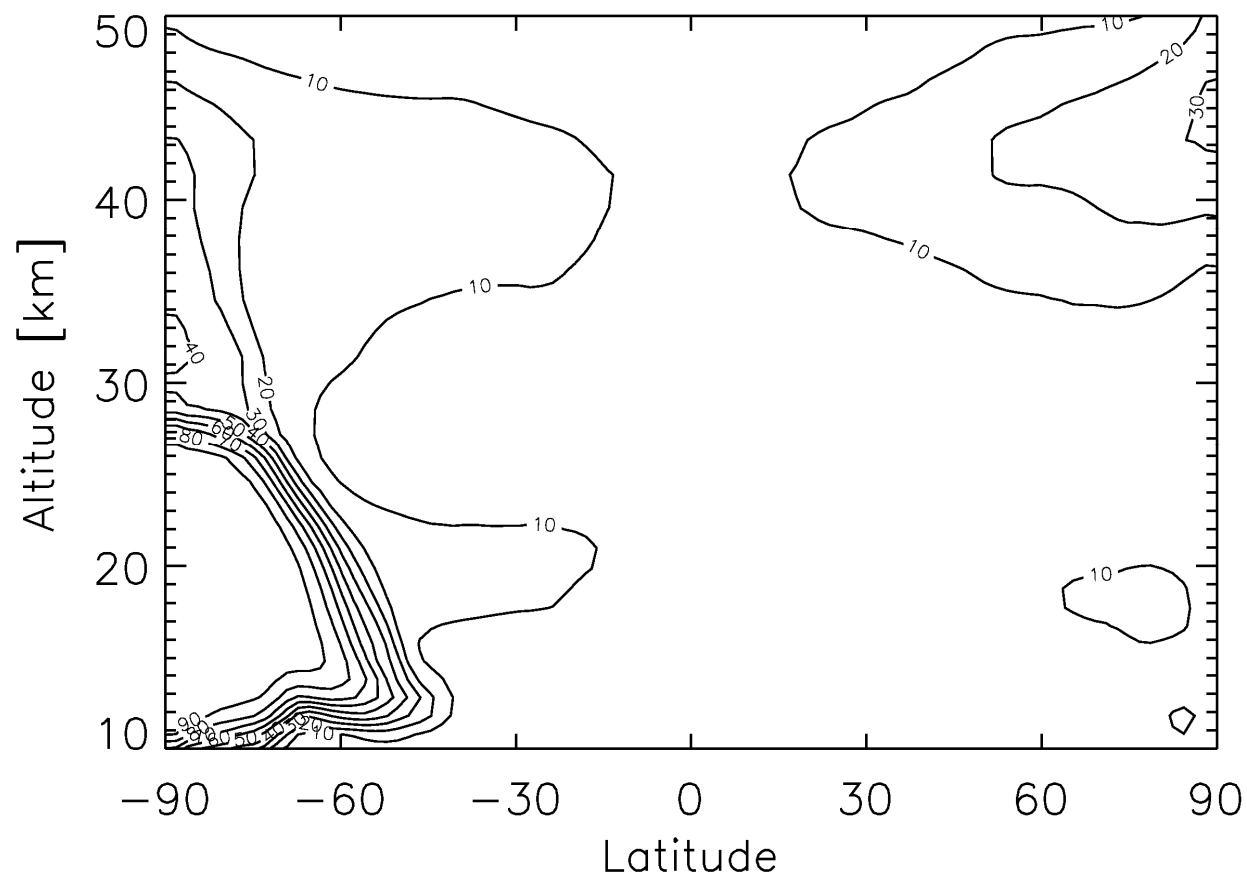

Figure 16. Percentage contribution to total ozone loss by halogen catalyzed cycles at fall equinox. 


\title{
Section 4
}

\section{Assessment of the Impact of a $2050 \mathrm{H}_{2}$-based Transportation Sector on Air Quality in the Continental United States}

\author{
Seth Olsen and Don Wuebbles \\ University of Illinois at Urbana Champaign
}

\section{Introduction}

The quality of the air at the surface of the Earth is vitally important to the health of humans, agriculture, and ecosystems. Measures of air quality are typically related to the ground level concentrations of key gaseous and particulate pollutants. These concentrations depend in a complicated manner on the emissions of the pollutants or their precursors and atmospheric photochemistry and transport processes. The impacts of these

pollutants are varied. For example, increased ground level ozone $\left(\mathrm{O}_{3}\right)$ can cause airway irritation, coughing, wheezing and breathing difficulties, aggravation of asthma and increased susceptibility to respiratory illnesses like pneumonia and bronchitis, and, with repeated exposure, permanent lung damage. Increased ozone can also adversely affect ecosystem health and crop yields. When breathed, carbon monoxide (CO) is absorbed into the bloodstream where it displaces oxygen and bonds with the hemoglobin in blood depriving the body of oxygen. Airborne particulate matter less than 2.5 microns in diameter (PM2.5) is able to travel deeply into the respiratory tract and lungs where it can cause short-term health effects such as eye, nose, throat and lung irritation, coughing, sneezing, runny nose and shortness of breath. Long term exposure may be associated with increased rates of chronic bronchitis, reduced lung function and increased mortality from lung cancer and heart disease. Other components of smog, e.g., peroxyacetyl nitrate (PAN) are also irritants with adverse health impacts.

It has been known since the early 1950s that one of the primary components of photochemical smog is ozone [Haagen-Smit 1952]. Ozone is not emitted directly by car engines or by industrial operations, but formed by the reaction of volatile organic compounds (VOC) and nitrogen oxides $\left(\mathrm{NOx}=\mathrm{NO}+\mathrm{NO}_{2}\right.$, where $\mathrm{NO}$ is nitric oxide and $\mathrm{NO}_{2}$ is nitrogen dioxide) in air exposed to sunlight and warm temperatures [see, for example, textbooks such as Seinfeld and Pandis (2006) or Jacob (1999), as well as the 
companion report to this one on tropospheric impacts]. VOC and NOx are known as ozone precursors because they are necessary for and typically lead to the production of tropospheric ozone. The predominant source of these ozone precursors is emissions from the incomplete combustion of fossil fuels, for example from automobiles. In many countries concerns about air quality have led to regulatory controls on the emissions of these ozone precursors. The Clean Air Act of 1963 was the first federal legislation regarding air pollution control and has been followed by further legislation aimed at improving ground level air quality particularly in large cities. This legislation has been largely successful with emissions reductions of $\sim 50 \%$ (VOC) and 30\% (NOx) between 1980 and 2007 even though vehicle miles traveled more than doubled and energy consumption increased by $30 \%$ (US EPA 2008, Weaver et al. 2009).

Though efforts are ongoing to improve air quality through controls on automobile emissions there has been less emphasis on moving away from fossil fuels and internal combustion engine (ICE) technology to other energy technologies. However, there are possibly large benefits to moving towards hydrogen $\left(\mathrm{H}_{2}\right)$ as a transportation energy carrier and to $\mathrm{H}_{2}$ powered fuel cell engines. Hydrogen fuel cell systems emit limited amounts of water and these emissions would displace fossil fuel combustion emissions of NOx, VOC, CO, and particulate matter, all of which contribute to the environmental problems inherent with fossil fuel combustion. Additionally, if the $\mathrm{H}_{2}$ is made from renewable non-polluting energy sources, e.g., wind or solar power, there will be an associated reduction in the emissions of carbon dioxide $\left(\mathrm{CO}_{2}\right)$, and in the case of coal combustion, sulfur dioxide $\left(\mathrm{SO}_{2}\right)$. Although there would undoubtedly be some leakage of $\mathrm{H}_{2}$ to the environment, it is postulated that the environmental benefit of the decrease in fossil fuel related emissions would more than outweigh the possible adverse impact of the emitted $\mathrm{H}_{2}$. The complete conversion to an $\mathrm{H}_{2}$-powered transportation sector would certainly take some time as it would require a large-scale change in delivery infrastructure and an entirely new fleet of automobiles worldwide.

Here we evaluate the possible impact on United States air quality of converting to an $\mathrm{H}_{2}$-powered transportation sector in 2050. Since future changes in transportation are exceedingly difficult to project and highly uncertain we evaluate several growth and technology scenarios chosen to bracket the possible future paths. Two growth paths were selected based on the Intergovernmental Panel on Climate Change (IPCC) low emitting 
(B1) and high emitting (A1Fi) scenarios for 2050. The A1FI scenario represents a future where the world is assumed to evolve with rapid economic growth relying intensively on fossil fuel; whereas in the B1 scenario the world's economic structures are projected to rapidly transform to a service-and-information based society with minimal reliance on fossil fuels. For each of these growth scenarios two technology adoption scenarios were chosen, the first assumes fuel cell technology with its corresponding decrease in NOx, VOC, $\mathrm{CO}$, and aerosol precursor emissions, and the second assumes $\mathrm{H}_{2}$ burning internal combustion engines in which VOC, $\mathrm{CO}$, and aerosol precursors are reduced but NOx emissions are not reduced. These scenarios currently represent the range of the best available evaluation of future emissions from human related activities for the extent of this century. This report is a companion report to the emissions report and the tropospheric and stratospheric impact reports.

\section{Methods}

We are using the Community Multiscale Air Quality Modeling System (CMAQ) version 4.6 [see www.cmaq-model.org] to evaluate the regional air quality impacts of an $\mathrm{H}_{2}$ economy. The CMAQ model was initially released to the public by U.S. Environmental Protection Agency (EPA) in 1998 and has undergone many revisions and improvements since [e.g., Appel 2007, 2008]. The CMAQ modeling system was designed to approach air quality as a whole by including state-of-the-science capabilities for modeling multiple air quality issues, including tropospheric ozone, fine particles, toxics, acid deposition, and visibility degradation. In this way, the development of CMAQ involves the scientific expertise from each of these areas and combines the capabilities to enable a community modeling practice. CMAQ was also designed to have multi-scale capabilities so that separate models were not needed for urban and regional scale air quality modeling. The CMAQ model is used for research and regulatory applications by the EPA, states, and other researchers and has been extensively evaluated against observations [e.g., most recently, Appell 2007, 2008; Sarwar, et al, 2008; Mathur et al., 2008, Roy, et al., 2007; Eder and Yu, 2006; Tong and Mauzerall, 2006]. As the EPA recommended model for use in air quality evaluation the source code and algorithms also undergo a regular peer-review process. The results of which are available from www.cmaq-model.org. 
For this study the model horizontal resolution is $30 \mathrm{~km}$ by $30 \mathrm{~km}$ with 22 vertical layers from the surface to $13 \mathrm{~km}$. It has a relatively good resolution in the boundary layer with 5 layers in the first $\mathrm{km}$. The meteorological data to drive CMAQ is from a climate version of the MM5 model [CMM5; e.g., Liang et al., 2001] for the year 1995. We have chosen to use 1995 meteorology since here our focus is on air quality and photochemistry influenced impacts due to changes in emissions and because predicting meteorological changes in 2050 with any confidence is fraught with uncertainty (in addition, previous studies [e.g., Lin et al., 2008] have shown that future climate changes will likely have less effect on air quality than the future changes in emissions). For this study CMAQ uses the Carbon Bond 5 gas phase photochemistry package [Luecken, et al., 2008; Sarwar, et al., 2008] with 56 species and 156 reactions. The aerosol chemistry package is coupled to the gas phase chemistry package and contains 34 transported aerosol modes. The aerosol package represents the particle size distribution as the superposition of three lognormal modes. The processes of coagulation, particle growth by the addition of new mass, and particle formation are included. Time stepping is done utilizing an analytical solution to the differential equations for the conservation of number and species mass conservation. The simulation was carried out with a 12 minute dynamical timestep and the chemistry package using a 2.5 min sub-timestep. Detailed descriptions of the mechanisms, algorithms, and implementation are available in the CMAQ scientific documentation (see www.epa.gov/asmdnerl/CMAQ/CMAQscienceDoc.html).

Boundary conditions for the CMAQ model simulations are based on the corresponding global tropospheric model simulations. The global tropospheric simulations where carried out with the Community Atmospheric Model with chemistry (CAMchem). CAMchem development is lead by the National Center for atmospheric Research with considerable contributions from the community including the National Science Foundation, the Department of Energy, the National Aeronautics and Space Administration, and the University Corporation for Atmospheric Research. For the tropospheric simulations CAMchem was run with a horizontal resolution of $1.9^{\circ}$ latitude by $2.5^{\circ}$ longitude and 16 vertical levels and a comprehensive tropospheric chemistry package. For details on CAMchem and the tropospheric simulation see the companion report on possible future $\mathrm{H}_{2}$ impacts on tropospheric composition and chemistry. 
Here we evaluate the impact of a future $\mathrm{H}_{2}$-based transportation sector for two technology options following two growth paths for a total of six simulations (a Baseline simulation and two technology option simulations for each growth scenario). The base emissions for the regional simulations are based on emissions from the Sparse Matrix Operator Kernel Emissions (SMOKE) emissions processor [see www.smoke-model.org] using the U.S. National Emissions Inventory (NEI) for 2002. These emissions (NOx, CO, speciated VOC, etc.) were developed at a time resolution of one hour. Due to the large difference between the CAMchem global model resolution and the CMAQ regional horizontal resolution $(30 \mathrm{~km} \times 30 \mathrm{~km})$ and temporal resolutions and in order to keep changes in the regional emissions consistent with changes in the global emissions inventories, the 2002 SMOKE-based emissions were scaled for the future scenarios using scaling factors calculated from changes in emissions on the global grid. These scaling factors are species specific for the major species, e.g., NOx, CO, some VOC and are mapped to the closest species in the lumped mechanism where there is not a direct correspondence. A detailed description of the emissions are presented in the companion Emissions Report.

The two technology options for $\mathrm{H}_{2}$ utilization in road transportation evaluated here are Fuel Cell technology $\left(\mathrm{H}_{2}-\mathrm{FC}\right)$ and Internal Combustion Technology $\left(\mathrm{H}_{2}-\mathrm{ICE}\right)$. The two technologies differ in their related emissions. In the fuel cell technology option background atmospheric $\mathrm{H}_{2}$ concentrations are higher due to $\mathrm{H}_{2}$ leakage and emissions of all combustion related byproducts including $\mathrm{CO}, \mathrm{NOx}\left(=\mathrm{NO}+\mathrm{NO}_{2}\right)$, soot, $\mathrm{SO}_{2}$, and volatile organic compounds (VOC) are greatly reduced. In the ICE scenario background atmospheric $\mathrm{H}_{2}$ concentrations are higher due to $\mathrm{H}_{2}$ leakage and emissions of all combustion related byproducts except NOx are greatly reduced. NOx emissions are not reduced since they are created from air driven high temperature combustion in the internal combustion engine while $\mathrm{CO}, \mathrm{VOC}, \mathrm{SO}_{2}$, and soot emissions are still reduced since $\mathrm{H}_{2}$ is not a hydrocarbon.

Monthly mean lateral boundary conditions are taken from the corresponding global CAMchem simulations. Monthly varying background concentrations of methane $\left(\mathrm{CH}_{4}\right)$ and hydrogen $\left(\mathrm{H}_{2}\right)$ were also taken from the CAMchem simulations. Annual average $\mathrm{CH}_{4}$ and $\mathrm{H}_{2}$ concentrations are shown in Table 1. Seasonal variations were typically relatively small with peak to peak amplitudes less than $5 \%$ of the mean 
concentration. While $\mathrm{CH}_{4}$ and $\mathrm{H}_{2}$ are important to tropospheric background chemistry, they have a relatively small impact on urban air quality due to their low chemical reactivity. Although the total atmospheric lifetime of $\mathrm{H}_{2}$ is $\sim 2$ years, the atmospheric chemical lifetime is $\sim 9$ years, similar to the $\mathrm{CH}_{4}$ lifetime [e.g., Novelli et al. 1999; Ehhalt and Rohrer 2008, IPCC 2007]). The model was spun up for one month to eliminate the impact of the initial chemical atmospheric state which typically takes a few days (e.g., Tong and Mauzerall 2007) and then a one year simulation was run. One hour average model data was archived and used for this analysis.

\section{Results}

This impact assessment focuses on the continental United States in 2050 and evaluates the $\mathrm{H}_{2}$ fuel cell $\left(\mathrm{H}_{2}-\mathrm{FC}\right)$ and $\mathrm{H}_{2}$ internal combustion engine $\left(\mathrm{H}_{2}-\mathrm{ICE}\right)$ technology adoption scenarios for the A1Fi and B1 IPCC future growth scenarios. The $\mathrm{H}_{2}$-FC scenario represents the adoption of $\mathrm{H}_{2}$ fuel cell technology with reduced NOx and VOC emissions while the $\mathrm{H}_{2}$-ICE scenario represents a transitional scenario in which $\mathrm{H}_{2}$ is burned in internal combustion engines such that VOC emissions are reduced but NOx emissions are not. We focus on EPA National Ambient Air Quality Standards (NAAQS) criteria pollutants including $\mathrm{O}_{3}, \mathrm{CO}, \mathrm{PM} 2.5$, and $\mathrm{NOx}$ as these are among the most important species in terms of air quality. Relevant NAAQS standards are $75 \mathrm{ppb} 8$-hour average concentration for $\mathrm{O}_{3}, 9 \mathrm{ppm} 8$-hour average and $35 \mathrm{ppm}$ 1-hour average for $\mathrm{CO}$, $53 \mathrm{ppb}$ annual average and $100 \mathrm{ppb}$ 1-hour average for $\mathrm{NO}_{2}$, and 15 micrograms $/ \mathrm{m}^{3}$ annual average for PM 2.5.

For all scenarios and seasons, ozone concentrations are higher near population centers and along the west and east coasts with a plume extending off of the east coast during summer (Figures 1and 2). Both the A1Fi and B1 scenarios have higher concentrations during summer than in winter. Over the southwestern U.S. and parts of the East Coast, baseline monthly average 8-hour average maximum concentrations are projected to exceed the EPA standard of $75 \mathrm{ppb}$ over much of the summertime for the A1Fi scenario while during the winter it typically remains below $\sim 55 \mathrm{ppb}$. Concentrations are below the standard the vast majority of the time for the B1 Baseline scenario, below $\sim 56 \mathrm{ppb}$ and $\sim 48 \mathrm{ppb}$ in summer and winter respectively. Simulated ozone changes depend critically on the assumed growth scenario, technology scenario 
and season (Figures 1 and 3). Relatively large decreases in $\mathrm{O}_{3}$ concentrations are noted with the adoption of the $\mathrm{H}_{2}-\mathrm{FC}$ scenario. For both the $\mathrm{A} 1 \mathrm{Fi}$ and $\mathrm{B} 1$ scenarios the decreases are largest over population centers. Summertime decreases are nearly $18 \mathrm{ppb}$ for $\mathrm{A} 1 \mathrm{Fi}$ and $12 \mathrm{ppb}$ for the $\mathrm{B} 1$ scenario respectively. In stark contrast with these decreases for the $\mathrm{H}_{2}-\mathrm{FC}$ scenario there is little decrease in summertime $\mathrm{O}_{3}$ concentrations for the $\mathrm{H}_{2}$-ICE scenario over the vast majority of the U.S. (Figures 1 and 3). There are some relatively small reductions over the Los Angeles and San Francisco regions of California and a few very localized points in the Midwest but these reductions are much smaller than for the $\mathrm{H}_{2}-\mathrm{FC}$ scenario.

In wintertime there are generally smaller decreases in $\mathrm{O}_{3}$ concentrations over much of the U.S. Reductions for the $\mathrm{H}_{2}$-ICE scenarios are still much smaller than for the $\mathrm{H}_{2}$-FC scenario but the difference is not as stark. Interestingly, for the $\mathrm{A} 1 \mathrm{Fi} \mathrm{H}_{2}-\mathrm{FC}$ scenario in the wintertime, $\mathrm{O}_{3}$ concentrations actually increase slightly $(<\sim 5 \mathrm{ppb})$ for some localized areas in Midwest and Northeast and on the west coast. In general there are substantial decreases in $\mathrm{O}_{3}$ concentrations for the $\mathrm{H}_{2}$-FC scenarios while there are only small decreases in summertime $\mathrm{O}_{3}$ for the $\mathrm{H}_{2}$-ICE scenarios.

Examining the distribution of daily 8-hour maximum ozone concentrations over the year there is a large shift towards lower $\mathrm{O}_{3}$ impact for the $\mathrm{H}_{2}$-FC scenario for both the $\mathrm{A} 1 \mathrm{Fi}$ and B1 scenarios (Figures 2 and 4). In the A1Fi scenario much of the high tail above $80 \mathrm{ppb}$ is reduced thus achieving the EPA standard much more frequently (Figure 2). While the improvement for the A1Fi scenario is quite impressive, the $\mathrm{H}_{2}$-ICE scenario improvements are much more modest with small improvements in the $>80 \mathrm{ppb}$ tail. In the B1 scenarios (Figure 4) the standard is rarely exceeded in any scenario but there are still substantial improvements with the adoption of a fuel cell powered road sector. In the scenarios examined here summertime $\mathrm{O}_{3}$ over the continental U.S. is predominantly NOx controlled and emphasizes the importance of the utilization of non-combustion technology, e.g., fuel cells, in a future $\mathrm{H}_{2}$ economy in terms of $\mathrm{O}_{3}$ air quality.

Baseline $\mathrm{CO}$ concentrations are generally highest over the east coast in wintertime with monthly average wintertime concentrations of greater than $150 \mathrm{ppb}$ and $400 \mathrm{ppb}$ over much of the Eastern part of the U.S. for the B1 and A1Fi scenarios respectively (Figures 5 and 7). For each scenario examined here there are large decreases in $\mathrm{CO}$ 
concentrations due to the decrease in $\mathrm{CO}$ emissions. The largest decreases occur over areas with the highest emissions in the Baseline case and in contrast to some other pollutants there are only slight differences between the fuel cell and $\mathrm{H}_{2}$-ICE scenarios. Wintertime CO decreases are nearly $100 \mathrm{ppb}$ and $280 \mathrm{ppb}$ for the B1 and A1Fi scenarios over polluted regions, corresponding to decreases over much of the east coast of greater than $60 \%$. Summertime decreases are nearly half as large as wintertime decreases because the wintertime planetary boundary layer is shallower, there is less vigorous vertical mixing, and chemical loss is lower.

Overall there are significant decreases in CO concentrations throughout the year for all scenarios examined here (Figures 6 and 8). The daily 8-hour maximum $\mathrm{CO}$ distributions are shifted to substantially lower levels. The changes are most pronounced in the A1Fi scenarios and the decreases are somewhat larger for the $\mathrm{H}_{2}$-ICE scenarios than the $\mathrm{H}_{2}-\mathrm{FC}$ scenarios but the differences between technological scenarios are not as significant as the differences between the Baseline and either $\mathrm{H}_{2}$ scenario and both are well below the 8-hour maximum standard for $\mathrm{CO}$.

For the Baseline A1Fi and B1 cases PM2.5 concentrations are generally highest along the Ohio River Valley and the East Coast of the US and are typically higher in winter than in summer (Figures 9 and 11). Wintertime concentrations peak at roughly 9 microgram $/ \mathrm{m}^{3}$ for the A1Fi scenario and around 8 microgram $/ \mathrm{m}^{3}$ for the B1 scenario. As with $\mathrm{O}_{3}$, improvements in PM 2.5 air quality depend on the technology adoption scenario. PM 2.5 reductions are greatest with the $\mathrm{H}_{2}-\mathrm{FC}$ scenarios' $\mathrm{NOx}$ and VOC emissions reductions while the reductions are much more modest with the VOC only emissions reductions of the $\mathrm{H}_{2}$-ICE scenario. While the areas of largest absolute decrease correspond to the areas of highest initial concentrations the areas of largest relative decrease are typically over areas with lower initial concentrations in the Midwest and west coast. For the $\mathrm{H}_{2}$-FC scenario there are reductions of $\sim 1$ microgram $/ \mathrm{m}^{3}$ and 1.5 microgram $/ \mathrm{m}^{3}$ for the $\mathrm{B} 1$ and $\mathrm{A} 1 \mathrm{Fi}$ scenarios in winter over the regions of high concentration in the Midwest. For the $\mathrm{H}_{2}$-ICE scenario reductions are much more modest at around 1 and $0.5 \mathrm{microgram} / \mathrm{m}^{3}$ for the $\mathrm{A} 1 \mathrm{Fi}$ and $\mathrm{B} 1$ winter scenarios, respectively, and more concentrated on the eastern seaboard. The smaller PM 2.5 reduction in the $\mathrm{H}_{2}$ ICE scenario is due to the impact of nitrate aerosol PM 2.5 production from the NOx emissions, whereas in the $\mathrm{H}_{2}$-FC scenario there are reductions in soot, sulfate, and nitrate 
aerosols as well as secondary organic aerosol formation from decreases in VOC emissions. There are relatively small shifts in the PM 2.5 distributions (Figures 10 and 12). Compared to the other species there are modest improvements for all of the scenarios examined here with slightly larger improvements for the $\mathrm{H}_{2}-\mathrm{FC}$ scenarios than the $\mathrm{H}_{2}$ ICE scenario.

Baseline PAN distributions display a highly seasonal nature with summertime maxima along the East Coast and wintertime maxima in the Southwest, Texas, and Oklahoma (Figures 13 and 14). In both seasons maximum concentrations are nearly two times larger for the A1Fi scenario than the B1 scenario with peaks of $\sim 1.4$ ppb and 0.7 $\mathrm{ppb}$ for the A1Fi summertime and wintertime respectively. Summertime peak concentrations are typically nearly two times larger than found in wintertime. With the adoption of an $\mathrm{H}_{2}$ fuel cell powered road transportation sector, PAN concentrations decrease considerably with the largest summertime absolute decreases over the East and West coasts. Although the absolute decrease is larger over the east coast, the relative decrease is greater over the west coast $(\sim 70 \%)$ than over the east coast $(\sim 40 \%)$ for both the A1Fi and B1 scenarios. Summertime PAN decreases for the $\mathrm{H}_{2}$-ICE scenario are nearly negligible compared to the $\mathrm{H}_{2}-\mathrm{FC}$ scenario.

NOx is primarily of interest because of its importance as an ozone precursor and because one of its components $\left(\mathrm{NO}_{2}\right)$ is a NAAQS criteria pollutant. NOx concentration peaks tend to be highly localized for both the A1Fi and B1 scenarios, particularly in summertime (Figures 15 and 17). Peaks are concentrated in the northeast U.S. and in locations in the west, e.g., Los Angeles and Bay areas of California. Wintertime concentrations are higher than summertime concentrations and concentrations are higher in the A1Fi than B1 scenarios. There are large decreases in NOx concentrations with the adoption of an $\mathrm{H}_{2}$ fuel cell transportation sector, up to $\sim 13 \mathrm{ppb}(\sim 50 \%)$ in winter over the northeast U.S. for the A1Fi scenario (Figure 15). However, for the $\mathrm{H}_{2}$-ICE scenario there is almost no change in NOx concentrations evident in the figures. The NOx decreases in the $\mathrm{H}_{2}$-FC scenarios are substantial through out the seasons (Figures 16 and 18). Figures 16 and 18 are broken into two panels to cover the wide range of NOx concentrations. From the distributions it is evident that there are relatively small increases in NOx concentrations in the $\mathrm{H}_{2}$-ICE scenario relative to the Baseline scenario. 


\section{Comparison with Other Work}

Although there have been no other studies of the future air quality impact of an $\mathrm{H}_{2}$ based road transportation sector, several studies as discussed below have investigated the possible impacts of a present day hydrogen based economy. Our results are broadly consistent with these other findings. Schultz et al [2003] found large improvements in air quality with the present day adoption of a hydrogen powered economy using a three dimensional global chemistry model. As found here for the future scenarios, they noted large decreases in surface $\mathrm{O}_{3}, \mathrm{CO}$, and NOx concentrations, mostly due to the large $\mathrm{NOx}$, $\mathrm{CO}$, and VOC emissions reductions. As with our findings they also noted that the reduced NOx emissions are responsible for the majority of the $\mathrm{O}_{3}$ reductions and that at few areas in the Northern Hemisphere near major pollution sources the reduced NOx emissions actually led to higher $\mathrm{O}_{3}$ concentrations in wintertime. These findings are also consistent with Jacobson et al [2005] who reported large air quality improvements with the adoption of $\mathrm{H}_{2}$ fuel cell powered vehicles in the current fleet.

\section{Conclusions}

Overall the analyses presented here suggest that there are potentially substantial air quality improvements associated with a future $\mathrm{H}_{2}$ based transportation sector. However, the findings also highlight the advantages of utilizing $\mathrm{H}_{2}$ with a noncombustion technology, e.g., $\mathrm{H}_{2}$ fuel cells. If $\mathrm{H}_{2}$-ICE technology is used in an $\mathrm{H}_{2}$ transportation sector there are relatively small improvements in some key air quality species, e.g., $\mathrm{O}_{3}$, NOx, PAN, and less improvement in PM 2.5 air quality than in the $\mathrm{H}_{2}$ FC technology case. Conversely, these results suggest that there are substantial improvements in all of the key air quality indicators (e.g., $\mathrm{O}_{3}, \mathrm{NOx}, \mathrm{PM} 2.5, \mathrm{CO}, \mathrm{PAN}$ ) in a future fuel cell powered $\mathrm{H}_{2}$ based transportation sector. For the $\mathrm{H}_{2}-\mathrm{FC}$ scenarios most air quality improvements occur during times of maximum adverse impact thereby enhancing the efficacy of improvements in terms of regulatory and health impacts. For example, the largest $\mathrm{O}_{3}$ reductions occur during summertime when $\mathrm{O}_{3}$ concentrations are typically highest and thus seasonal peak $\mathrm{O}_{3}$ concentrations are reduced. Likewise the largest $\mathrm{CO}$ concentration reductions occur in wintertime when they are typically highest. Although there are many substantial uncertainties in predicting the future impacts of an $\mathrm{H}_{2}$ powered road transportation sector in 2050 including technology changes, growth 
changes, changes in emissions characteristics, changes in engine efficiencies, and climate changes, some inferences appear to be robust. For all $\mathrm{H}_{2}$-FC scenarios substantial air quality improvements were observed. This robust conclusion is directly due to the emissions reductions and independent of growth scenario and season. Conversely, it should be noted that the absolute air quality differences between the A1Fi and B1 growth scenarios are typically larger than the differences between technology scenarios, e.g., the air quality in a B1 type scenario is generally better than in any A1Fi scenario regardless of $\mathrm{H}_{2}$ technology adoption or not. In other words, a societal move away from fossil fuel use to alternative energy and transportation choices is generally better on air quality than remaining heavily fossil fuel intensive.

\section{Acknowledgements}

Funding for this study was provided by the U.S. Department of Energy through award number DE-FC36-07GO17109 to the University of Illinois project 'Evaluation of the Potential Environmental Impacts from Large-Scale Use and Production of Hydrogen in Energy and Transportation Applications'. 


\section{References}

Appel, W., A. Gilliland, G. Sarwar, and R.C. Gilliam, Evaluation of The Community Multiscale Air Quality (CMAQ) Model Version 4.5: Uncertainties and Sensitivities Impacting Model Performance: Part I - Ozone, Atmos. Environ., 41(40):9603-9613, (2007).

Appel, W., P. Bhave, A. Gilliland, G. Sarwar, and S.J. Roselle, Evaluation of The Community Multiscale Air Quality (CMAQ) Model Version 4.5: Uncertainties and Sensitivities Impacting Model Performance: Part II - Particulate Matter, Atmos. Environ., 42(24):6057-6066, (2008).

Eder, B. K. and S. Yu, A Performance Evaluation of the 2004 Release of Models-3 CMAQ, Atmos. Environ., 40(26):4811-4824, (2006).

Ehhalt, D. H. and F. Rohrer, The tropospheric cycle of $\mathrm{H}_{2}$ : a critical review, Tellus, $61 B$, 500-535, (2009).

IPCC, Climate Change 2007: The Physical Science Basis. Contribution of Working Group I to the Fourth Assessment Report of the Intergovernmental Panel on Climate Change [Solomon, S., D. Qin, M. Manning, Z. Chen, M. Marquis, K.B. Averyt, M. Tignor and H.L. Miller (eds.)]. Cambridge University Press, Cambridge, United Kingdom and New York, N.Y., U.S.A., 996 pp., (2007).

Jacob, D. J., Introduction to Atmospheric Chemistry, Princeton University Press, Princeton, N. J. U.S.A., (1999).

Jacobson, M., W. Colella, and D. Golden, Cleaning the air and improving health with hydrogen fuel-cell vehicles, Science, 308, 1901-1905, (2005).

Liang, X.-Z., K.E. Kunkel, and A.N. Samel, Development of a regional climate model for U.S. Midwest applications. Part 1: Sensitivity to buffer zone treatment, J. Climate., 14, 4363-4378, (2001).

Lin, J., K. O. Patten, K. Hayhoe, X. Liang, and D. Wuebbles, Effects of future climate and biogenic emissions changes on surface ozone over the United States and China, $J$. Appl. Met. Clim., 47 (7), 1888-1909, DOI: 10.1175/2007JAMC1681.1, (2008). 
Luecken, D. J., A. S. Phillips, G. Sarwar, and C. Jang, Effects of using the CB05 vs. SAPRC99 vs. CB4 chemical mechanism on model predictions: Ozone and gas-phase photochemical precursor concentrations, Atmos. Environ., 42, 5805-5820, (2008).

Mathur, R., S. Yu, D. Kang, and K. L. Schere, Assessment of the Winter-Time Performance of Developmental Particulate Matter Forecasts With the Eta-Cmaq Modeling System, J. Geophys. Res., 113(D02303):1-15, (2008).

Novelli, P. C., P. M. Lang, K. A. Massaie, D. F. Hurst, R. Myers, and J. W. Elkins, Molecular hydrogen in the troposphere: Global distribution and budget, J. Geophys. Res., 104, D23 30,427-30,444, (1999).

Roy, B., R. Mathur, A. Gilliland, and S. Howard, A Comparison of CMAQ-Based Aerosol Properties With Improve, Modis, and Aeronet Data, J. Geophys. Res., 112(D14 ):1-17, (2007).

Sarwar, G., D. J. Luecken, G. Yarwood, G. D. Whitten, and W. P. Carter, Impact of An Updated Carbon Bond Mechanism on Predictions from the CMAQ Modeling System: Preliminary Assessment, J. Appl. Met. Clim.. 47(1):3-14, (2008).

Schultz, M., T. Diehl, G. Brasseur, and W. Zittel, Air pollution and climate-forcing impacts of a global hydrogen economy, Science, 302, 624-627, (2003).

Seinfeld, J. H. and S. N. Pandis, Atmospheric Chemistry and Physics: From Air Pollution to Climate Change, second edition, John Wiley and Sons, Hoboken, N.J., U.S.A. (2006).

Tong, D. and D. Mauzerall, Spatial variability of summertime tropospheric ozone over the continental Unites States: Implications of an evaluation of the CMAQ model, Atmos. Environ. 40, 3041-3056, (2006).

U.S. EPA, National air quality: Status and trends through 2007, U.S. EPA EPA-454/R0806, 48pp., (2008).

Weaver, C. P., et al, A preliminary synthesis of modeled climate change impacts on U.S. regional ozone concentrations, BAMS, 1843-1863, Dec., (2009). 
Table 1. Annual average $\mathrm{CH}_{4}$ and $\mathrm{H}_{2}$ concentrations and relative seasonal variation (peak to peak amplitude (PTP) divided by the mean) over the continental U.S. model domain.

\begin{tabular}{|c|c|c|c|c|}
\hline & \multicolumn{2}{|l|}{$\mathrm{CH}_{4}$} & \multicolumn{2}{|l|}{$\mathrm{H}_{2}$} \\
\hline & $\begin{array}{l}\text { Annual Average } \\
{[\mathrm{ppm}]}\end{array}$ & PTP/mean [\%] & $\begin{array}{l}\text { Annual Average } \\
{[\mathrm{ppm}]}\end{array}$ & PTP/mean [\%] \\
\hline A1Fi Baseline & 2.66 & 2.0 & 0.84 & 3.3 \\
\hline $\mathrm{A} 1 \mathrm{Fi} \mathrm{H}_{2}-\mathrm{FC}$ & 2.66 & 2.0 & 1.20 & 3.7 \\
\hline $\mathrm{A} 1 \mathrm{Fi} \mathrm{H} \mathrm{H}_{2}$-ICE & 2.66 & 2.1 & 1.21 & 4.1 \\
\hline B1 Baseline & 1.90 & 2.3 & 0.56 & 4.1 \\
\hline $\mathrm{B} 1 \mathrm{H}_{2}-\mathrm{FC}$ & 1.90 & 2.2 & 0.73 & 3.7 \\
\hline $\mathrm{B} 1 \mathrm{H}_{2}$-ICE & 1.90 & 2.3 & 0.74 & 4.2 \\
\hline
\end{tabular}



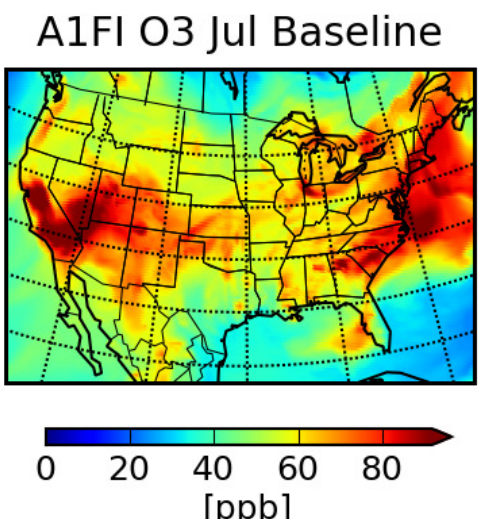

A1FI O3 Feb Baseline
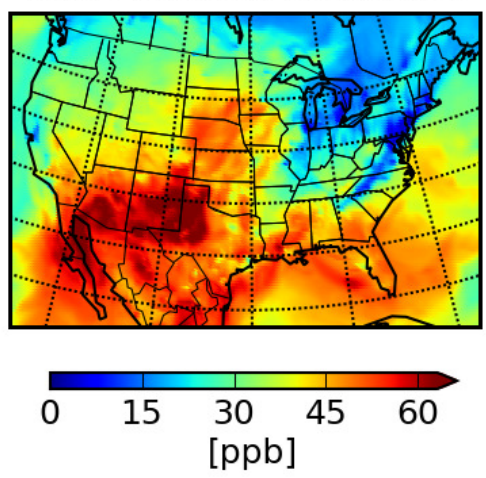

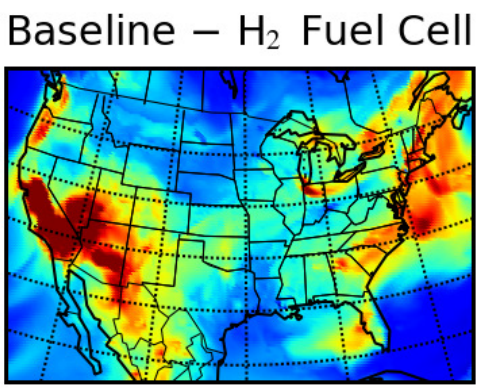

Baseline $-\mathrm{H}_{2}$ ICE
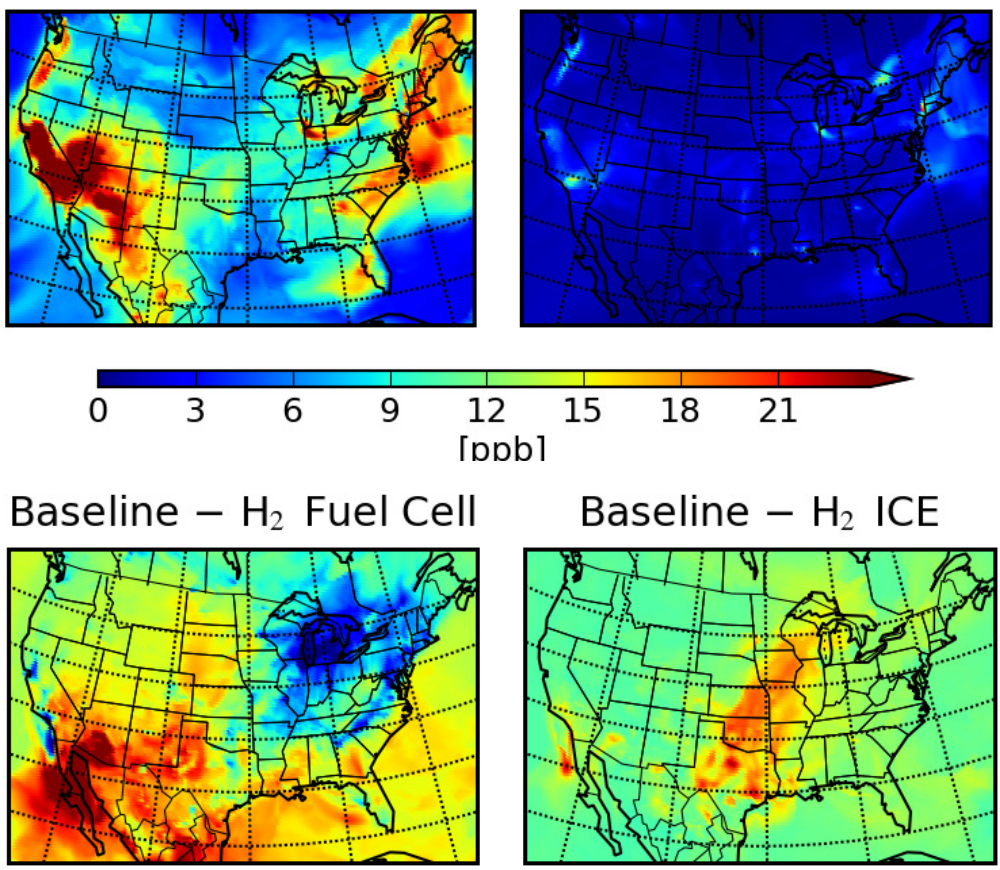

Baseline $-\mathrm{H}_{2}$ ICE
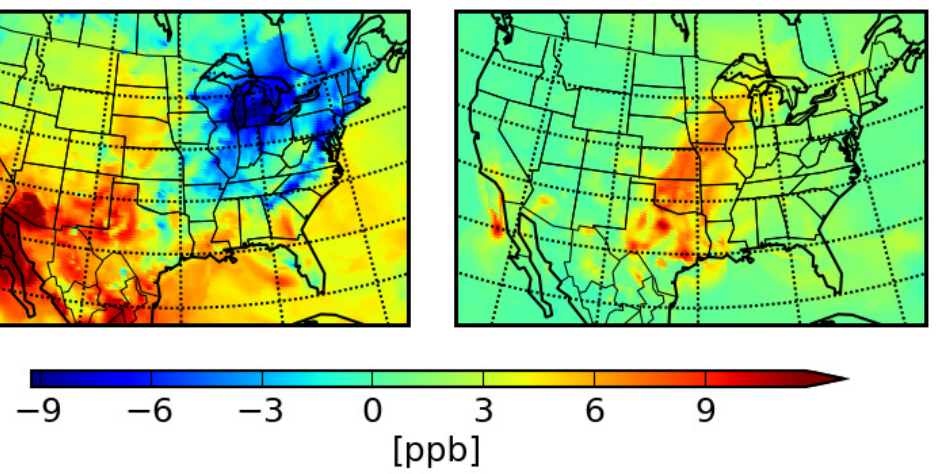

Figure 1. Monthly averages of the maximum daily 8-hour-average $\mathrm{O}_{3}$ concentrations for July (top) and Feb (bottom) for the A1Fi scenario across the contiguous United States. Each row contains the Baseline Case (left), difference between the Baseline and $\mathrm{H}_{2}$ - $\mathrm{FC}$ scenario (center), and difference between the Baseline and $\mathrm{H}_{2}$-ICE scenario (right). Data are averaged over the lowest three model levels $(\sim 250 \mathrm{~m})$. Note that the scales are different between panels. 


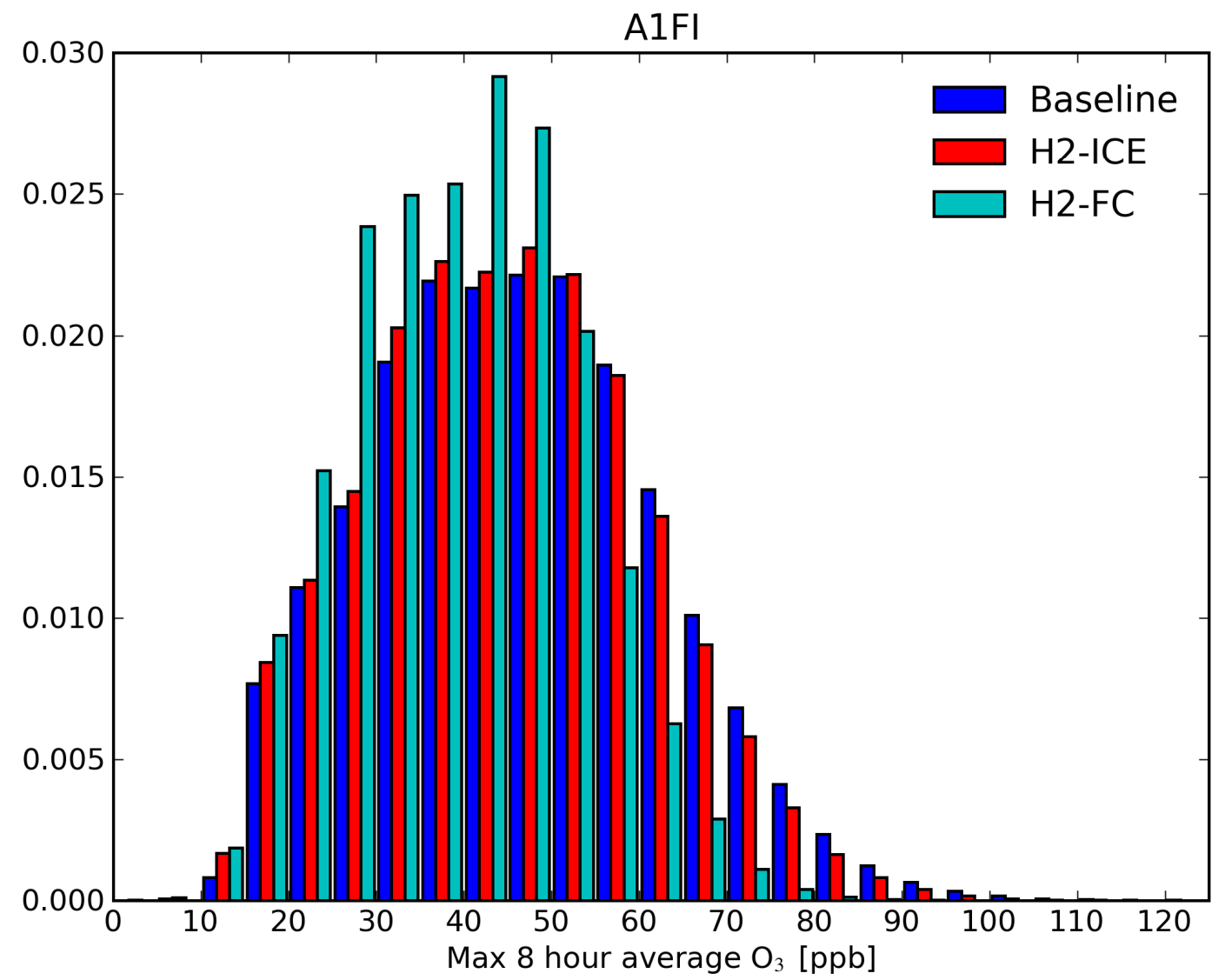

Figure 2. Normalized probability distribution $[\# / \mathrm{ppb}]$ of simulated surface daily 8-hour average maximum $\mathrm{O}_{3}$ concentrations over 1 year for the A1FI Baseline, $\mathrm{H}_{2}$-ICE, and $\mathrm{H}_{2}$ FC scenarios across the model domain. 

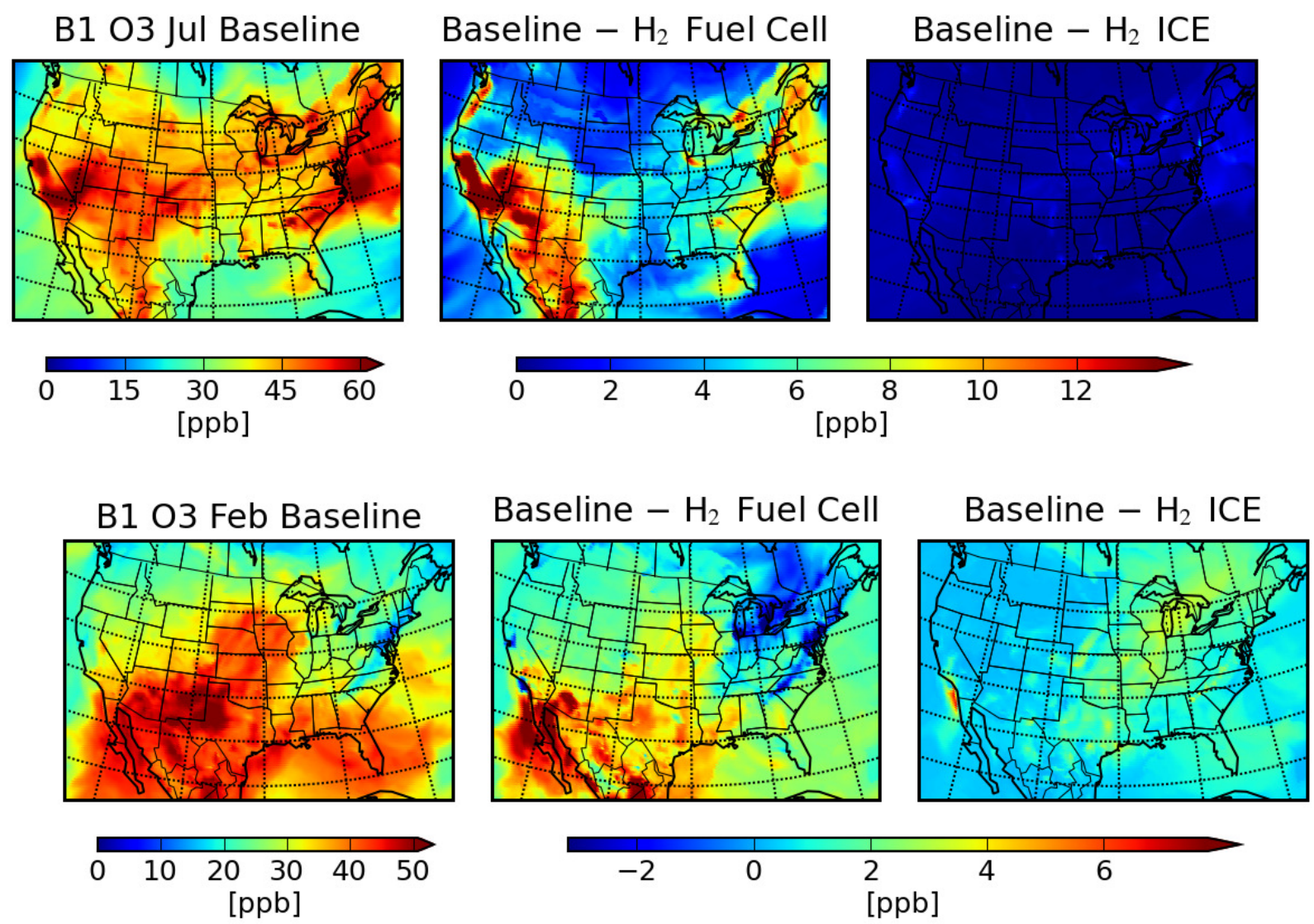

Figure 3. Monthly averages of the maximum daily 8-hour-average $\mathrm{O}_{3}$ concentrations for July (top) and Feb (bottom) for the B1 scenario across the contiguous United States. Each row contains the Baseline Case (left), difference between the Baseline and $\mathrm{H}_{2}-\mathrm{FC}$ scenario (center), and difference between the Baseline and $\mathrm{H}_{2}$-ICE scenario (right). Data are averaged over the lowest three model levels $(\sim 250 \mathrm{~m})$. Note that the scales are different between panels. 


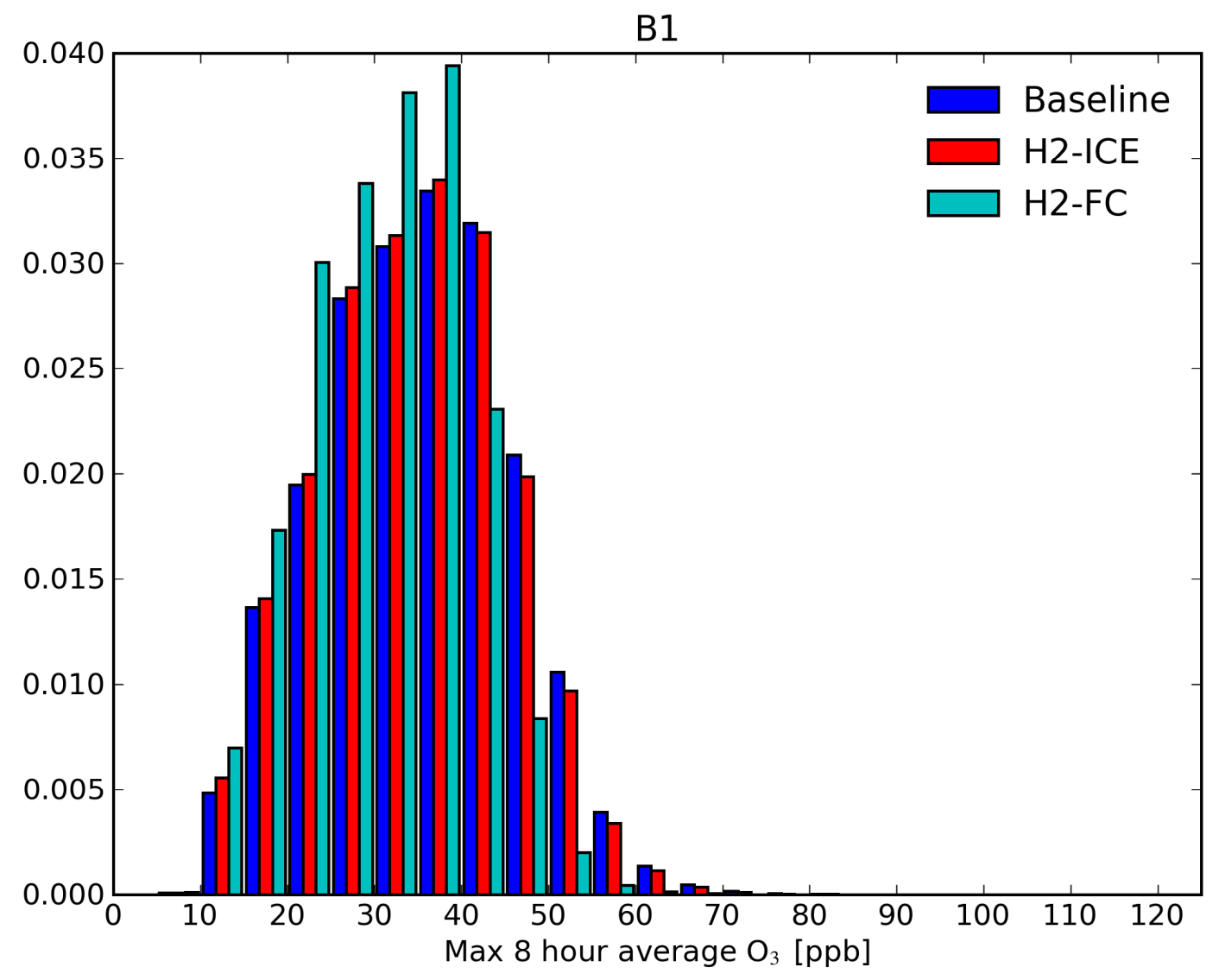

Figure 4. Normalized probability distribution $[\# / \mathrm{ppb}]$ of simulated surface daily 8-hour average maximum $\mathrm{O}_{3}$ concentrations over 1 year for the $\mathrm{B} 1$ Baseline, $\mathrm{H}_{2}$-ICE, and $\mathrm{H}_{2}-\mathrm{FC}$ scenarios across the model domain. 

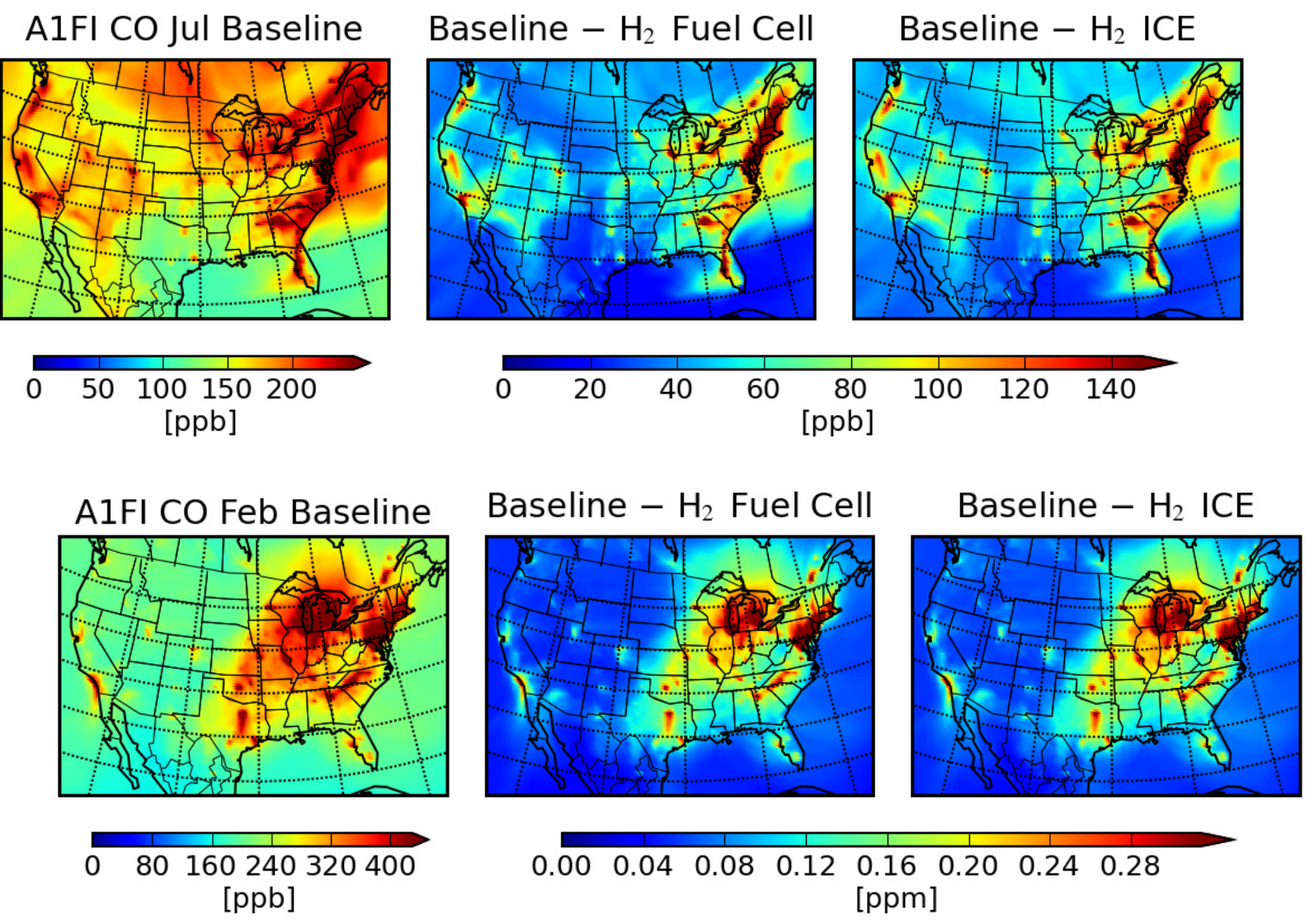

Figure 5. Monthly average CO concentrations for July (top) and Feb (bottom) for the A1Fi scenario across the contiguous United States. Each row contains the Baseline Case (left), difference between the Baseline and $\mathrm{H}_{2}-\mathrm{FC}$ scenario (center), and difference between the Baseline and $\mathrm{H}_{2}$-ICE scenario (right). Data are averaged over the lowest three model levels $(\sim 250 \mathrm{~m})$. Note that the scales are different between panels. 


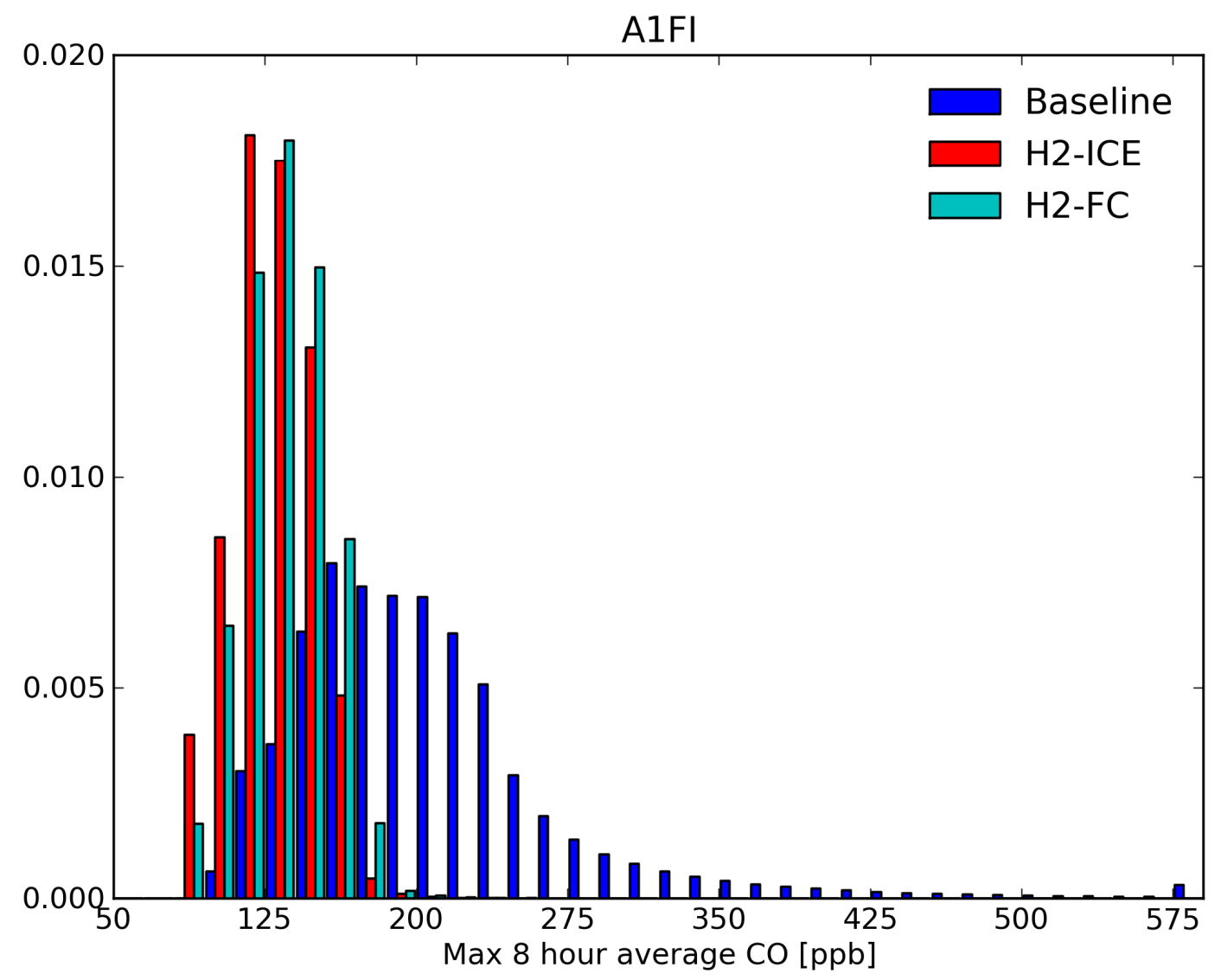

Figure 6. Normalized probability distribution [\#/ppb] of simulated surface daily 8-hour average maximum $\mathrm{CO}$ concentrations over 1 year for the A1FI Baseline, $\mathrm{H}_{2}$-ICE, and $\mathrm{H}_{2}$ FC scenarios across the model domain. 


\section{B1 CO Jul Baseline}
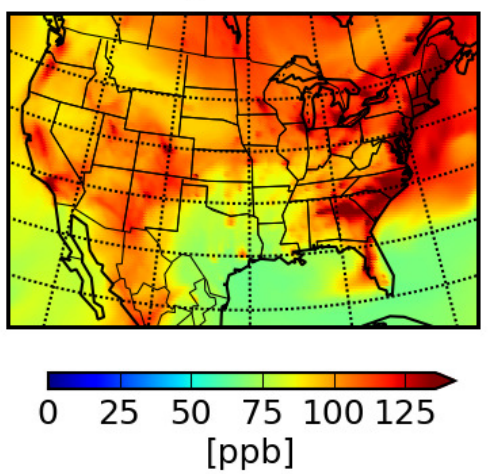
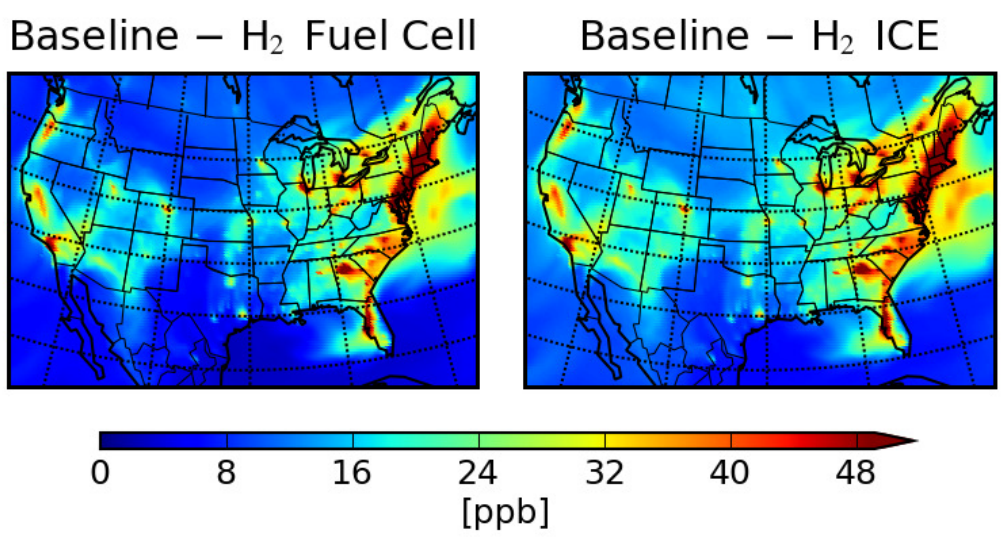

Figure 7. Monthly average CO concentrations for July (top) and Feb (bottom) for the B1 scenario across the contiguous United States. Each row contains the Baseline Case (left), difference between the Baseline and $\mathrm{H}_{2}$-FC scenario (center), and difference between the Baseline and $\mathrm{H}_{2}$-ICE scenario (right). Data are averaged over the lowest three model levels $(\sim 250 \mathrm{~m})$. Note that the scales are different between panels. 


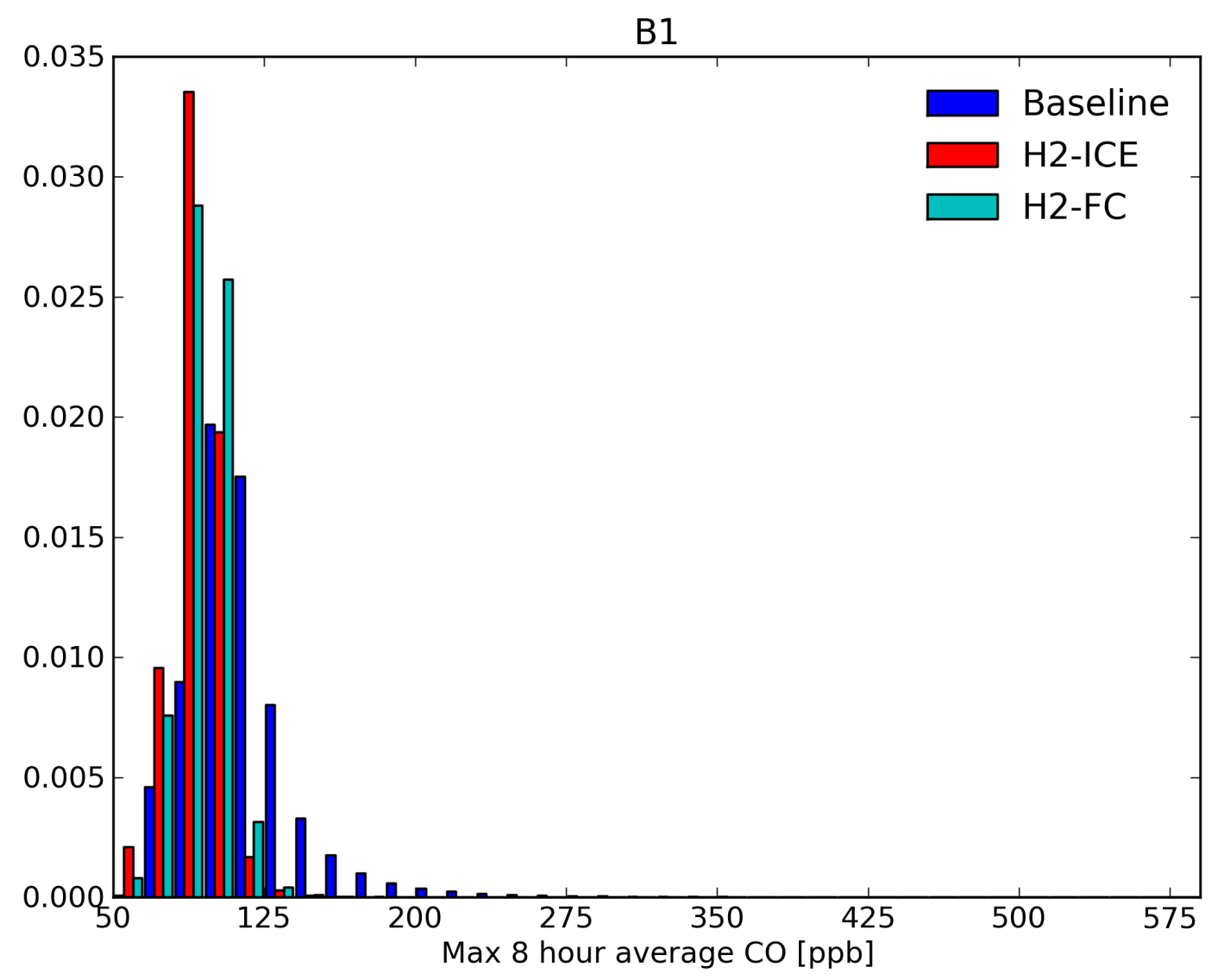

Figure 8. Normalized probability distribution $[\# / \mathrm{ppb}]$ of simulated surface daily 8-hour average maximum $\mathrm{CO}$ concentrations over 1 year for the $\mathrm{B} 1$ Baseline, $\mathrm{H}_{2}-\mathrm{ICE}$, and $\mathrm{H}_{2}$ FC scenarios across the model domain. 

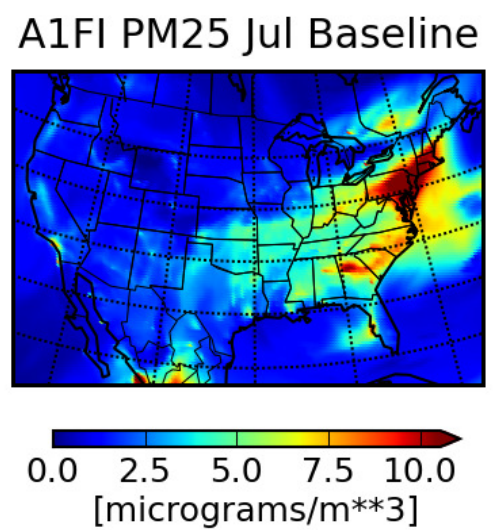

A1FI PM25 Feb Baseline
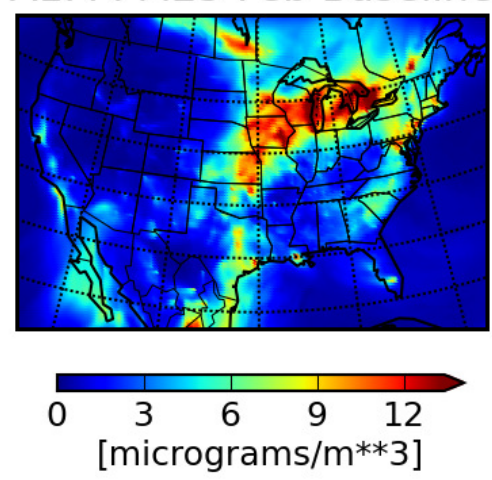

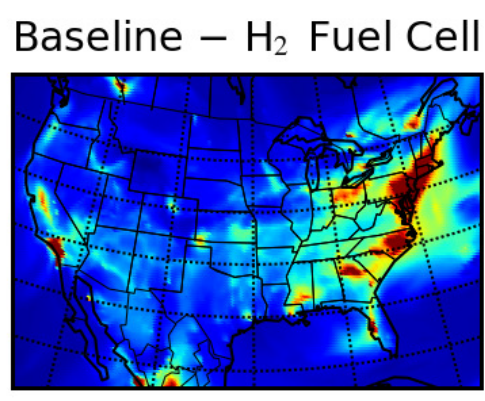

Baseline $-\mathrm{H}_{2}$ ICE
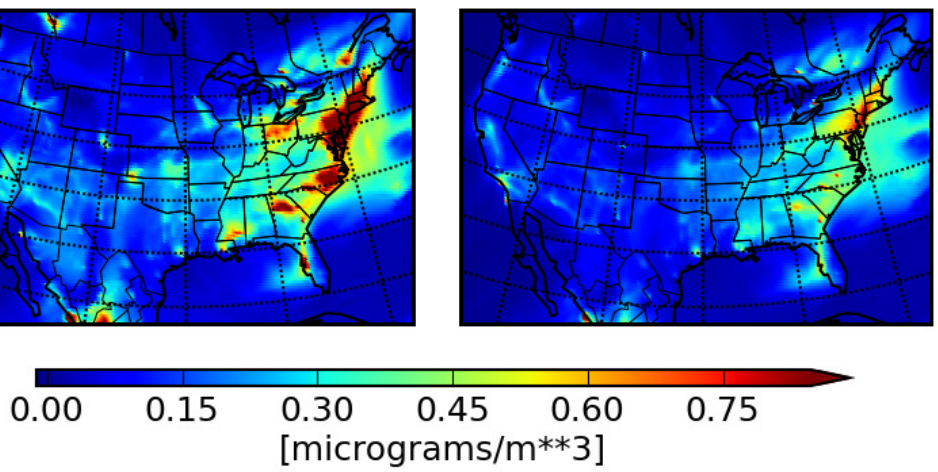

[micrograms $/ \mathrm{m}^{* * 3}$ ]

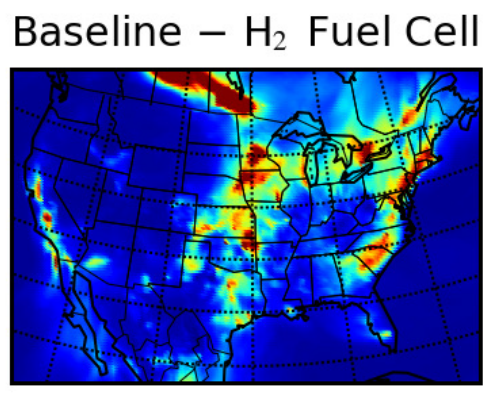

Baseline $-\mathrm{H}_{2}$ ICE
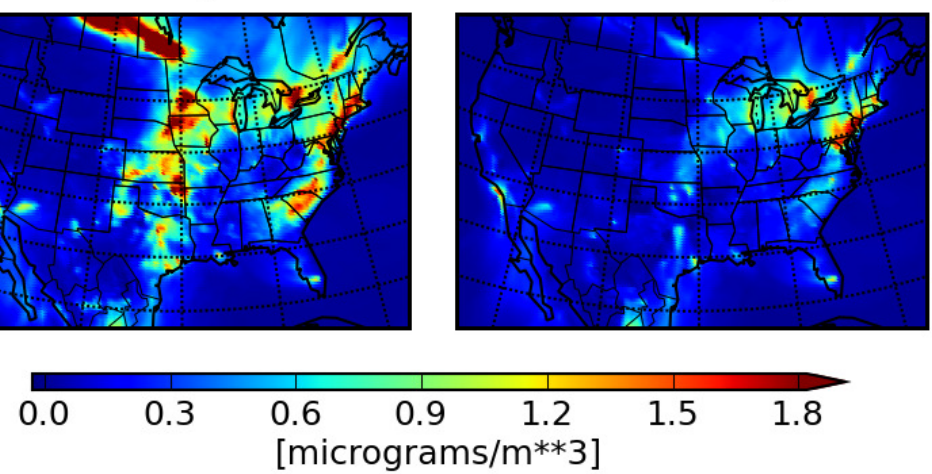

Figure 9. Monthly average PM 2.5 concentrations for July (top) and Feb (bottom) for the A1Fi scenario across the contiguous United States. Each row contains the Baseline Case (left), difference between the Baseline and $\mathrm{H}_{2}-\mathrm{FC}$ scenario (center), and difference between the Baseline and $\mathrm{H}_{2}$-ICE scenario (right). Data are averaged over the lowest three model levels $(\sim 250 \mathrm{~m})$. Note that the scales are different between panels. 


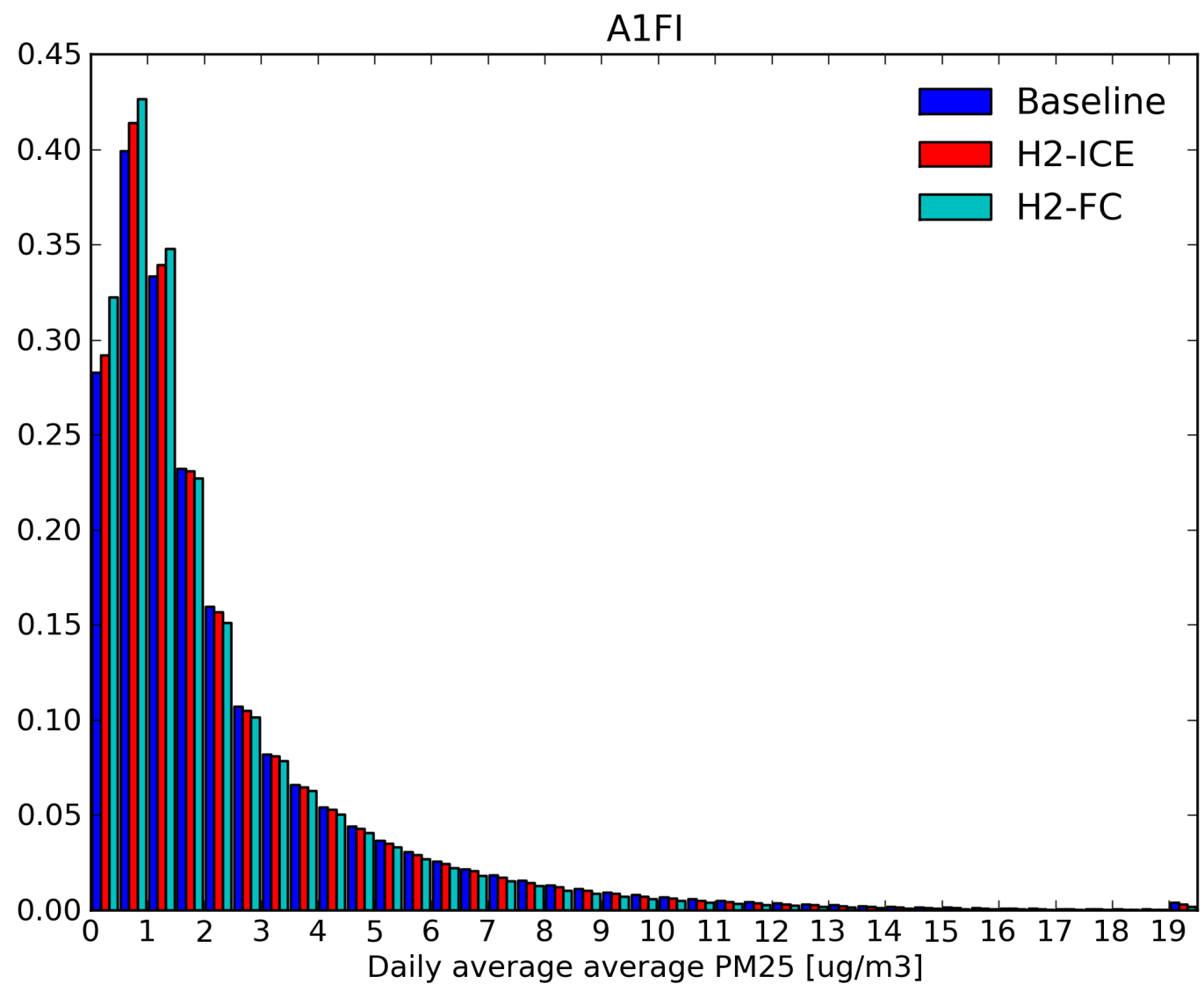

Figure 10. Normalized probability distribution $\left[\# / \mathrm{ug} \mathrm{m}^{-3}\right]$ of simulated surface daily average PM2.5 concentrations over 1 year for the A1FI Baseline, $\mathrm{H}_{2}$-ICE, and $\mathrm{H}_{2}$-FC scenarios across the model domain. 

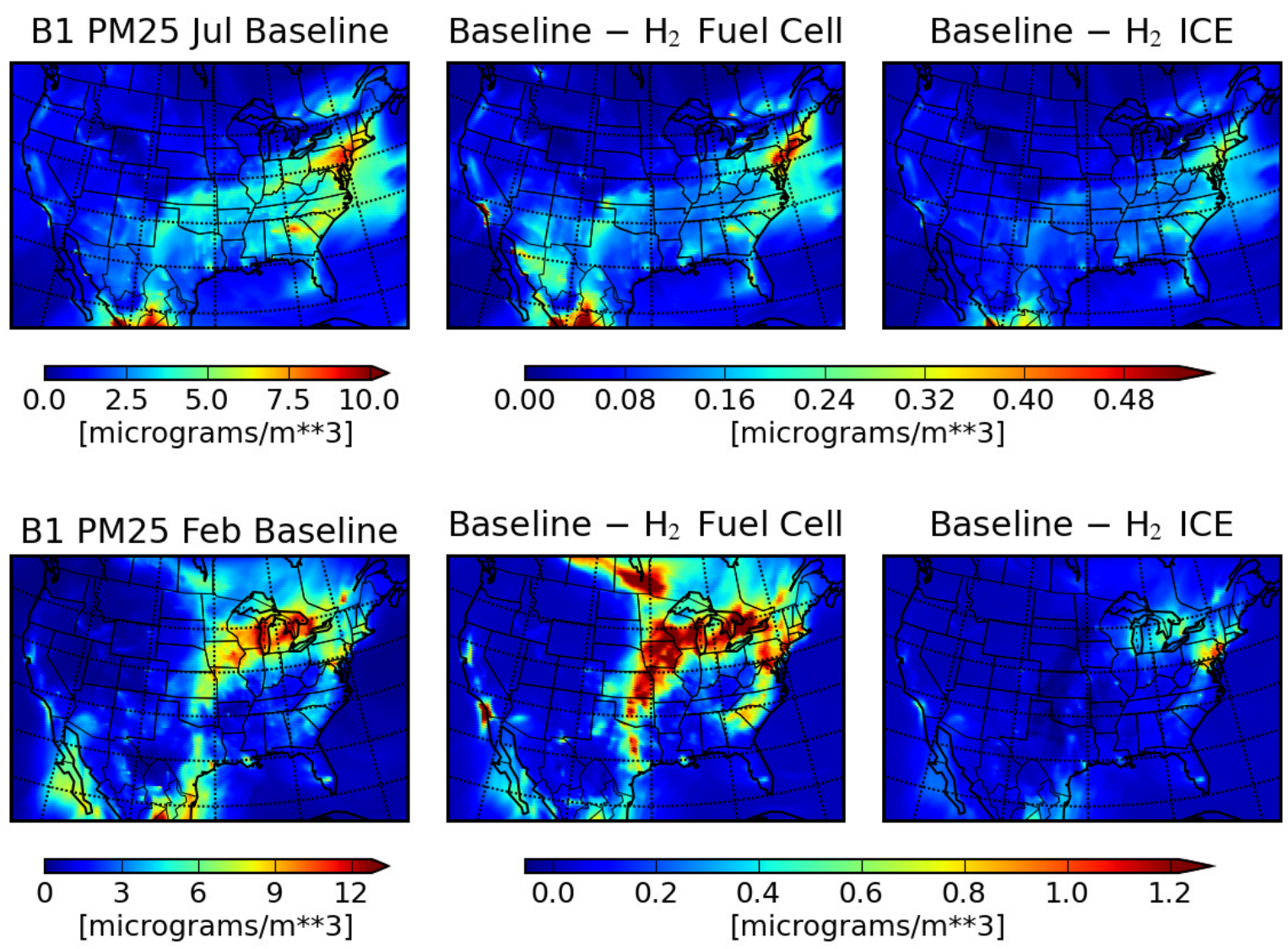

Figure 11. Monthly average PM 2.5 concentrations for July (top) and Feb (bottom) for the B1 scenario across the contiguous United States. Each row contains the Baseline Case (left), difference between the Baseline and $\mathrm{H}_{2}-\mathrm{FC}$ scenario (center), and difference between the Baseline and $\mathrm{H}_{2}$-ICE scenario (right). Data are averaged over the lowest three model levels $(\sim 250 \mathrm{~m})$. Note that the scales are different between panels. 
B1

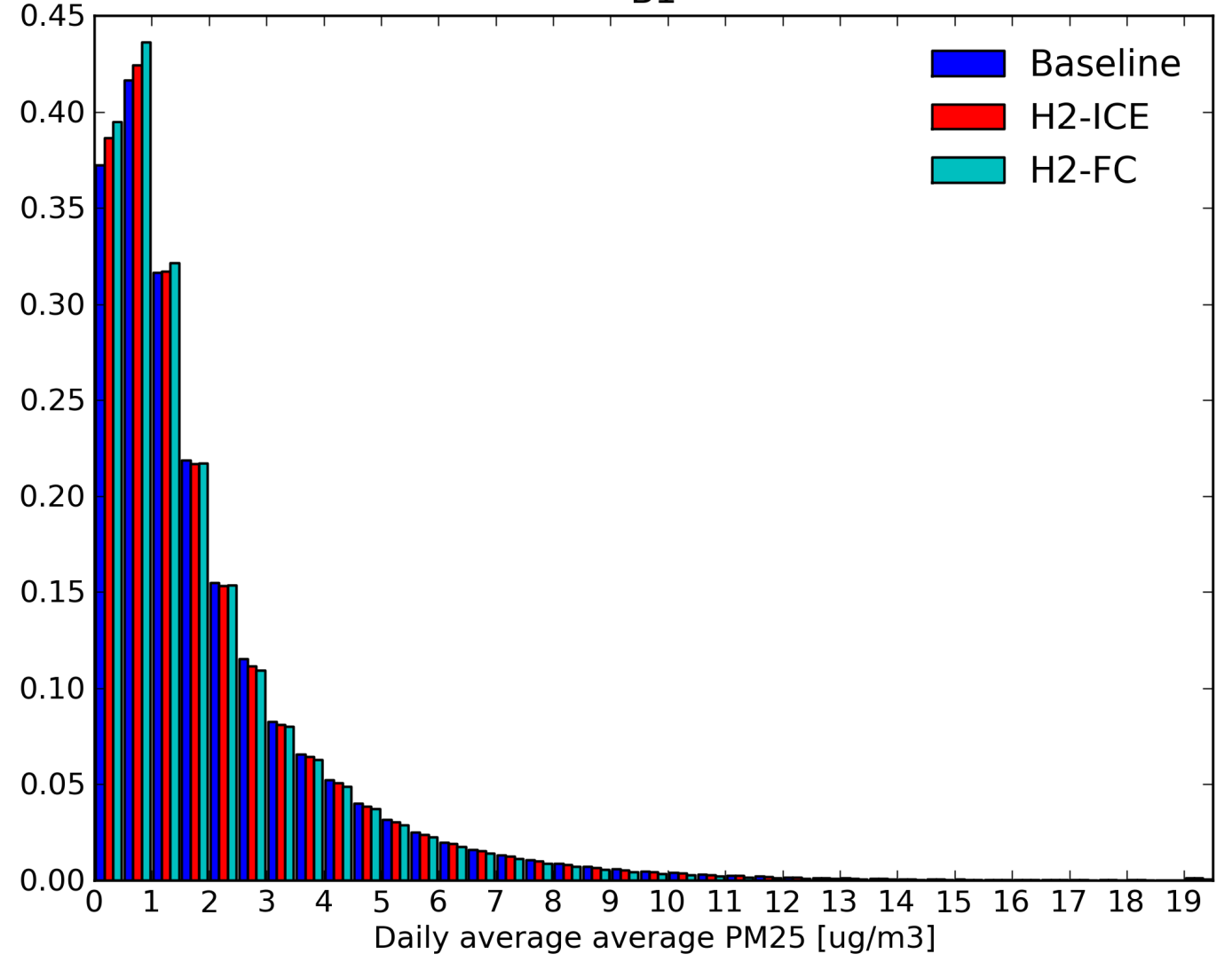

Figure 12. Normalized probability distribution $\left[\# / \mathrm{ug} \mathrm{m}^{-3}\right]$ of simulated surface daily average PM2.5 concentrations over 1 year for the B1 Baseline, $\mathrm{H}_{2}$-ICE, and $\mathrm{H}_{2}$-FC scenarios across the model domain. 
A1FI PAN Jul Baseline
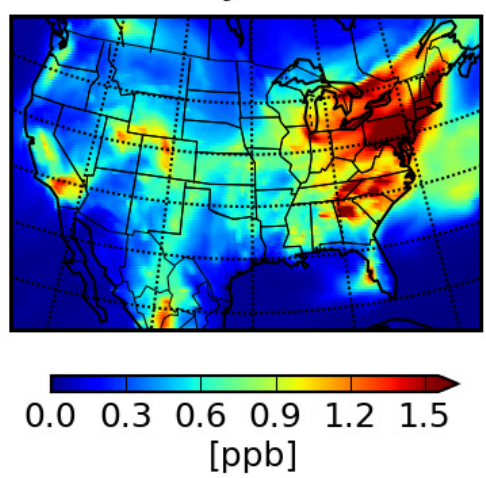

A1FI PAN Feb Baseline
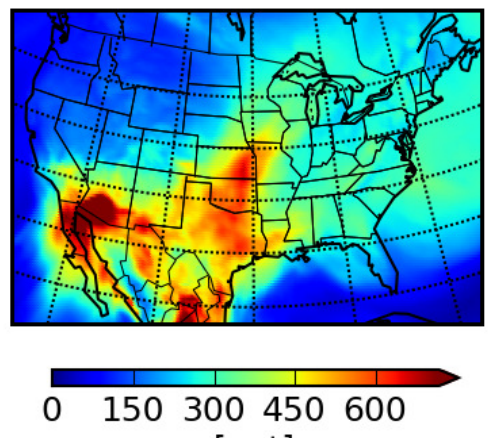

[ppt]

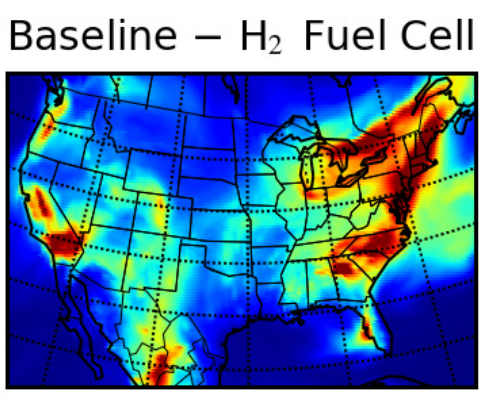

Baseline $-\mathrm{H}_{2}$ ICE
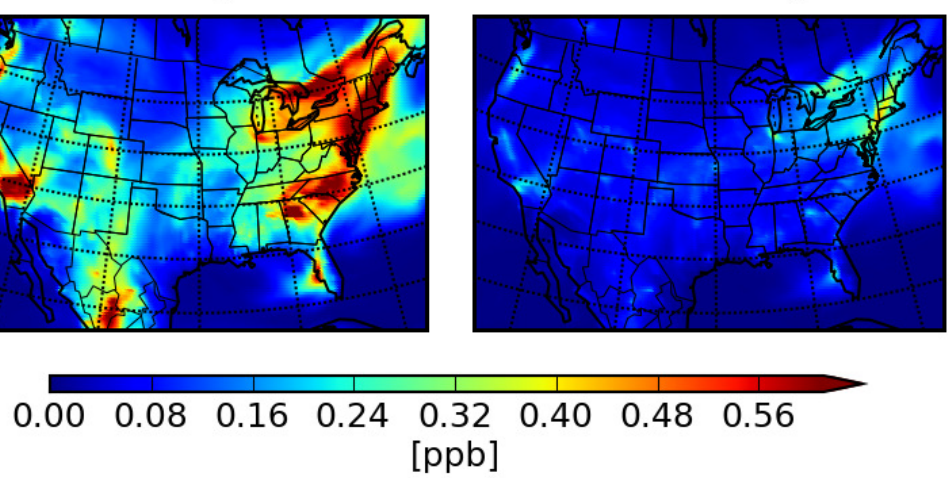
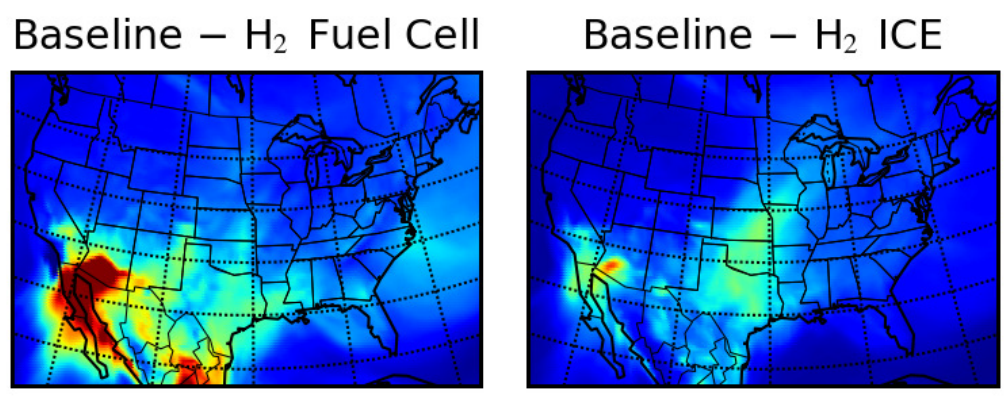

0
50
100150
200

$250 \quad 300 \quad 350$ [ppt]

Figure 13. Monthly average PAN concentrations for July (top) and Feb (bottom) for the A1Fi scenario across the contiguous United States. Each row contains the Baseline Case (left), difference between the Baseline and $\mathrm{H}_{2}-\mathrm{FC}$ scenario (center), and difference between the Baseline and $\mathrm{H}_{2}$-ICE scenario (right). Data are averaged over the lowest three model levels $(\sim 250 \mathrm{~m})$. Note that the scales are different between panels. 
B1 PAN Jul Baseline

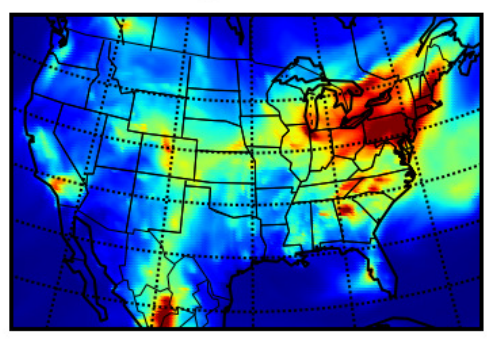

$0 \quad 150300450600750$ [ppt]

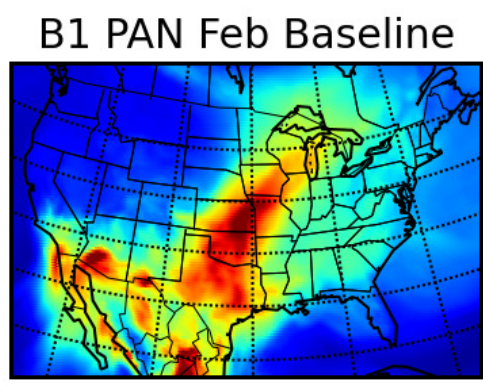

080160240320400

[ppt]

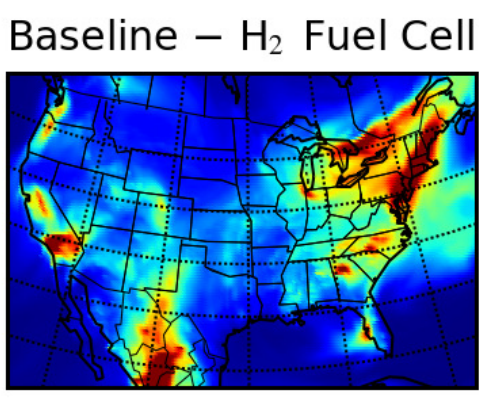

Baseline $-\mathrm{H}_{2}$ ICE
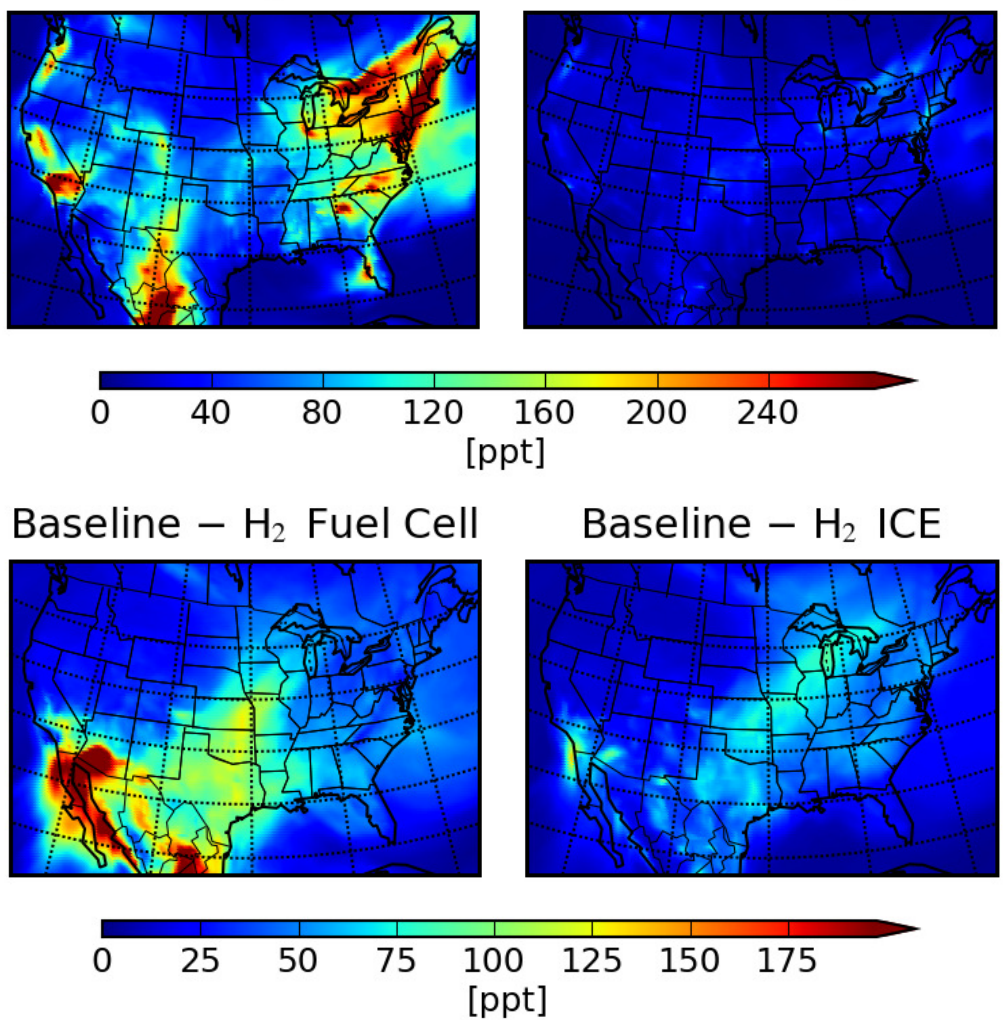

Figure 14. Monthly average PAN concentrations for July (top) and Feb (bottom) for the B1 scenario across the contiguous United States. Each row contains the Baseline Case (left), difference between the Baseline and $\mathrm{H}_{2}-\mathrm{FC}$ scenario (center), and difference between the Baseline and $\mathrm{H}_{2}$-ICE scenario (right). Data are averaged over the lowest three model levels $(\sim 250 \mathrm{~m})$. Note that the scales are different between panels. 

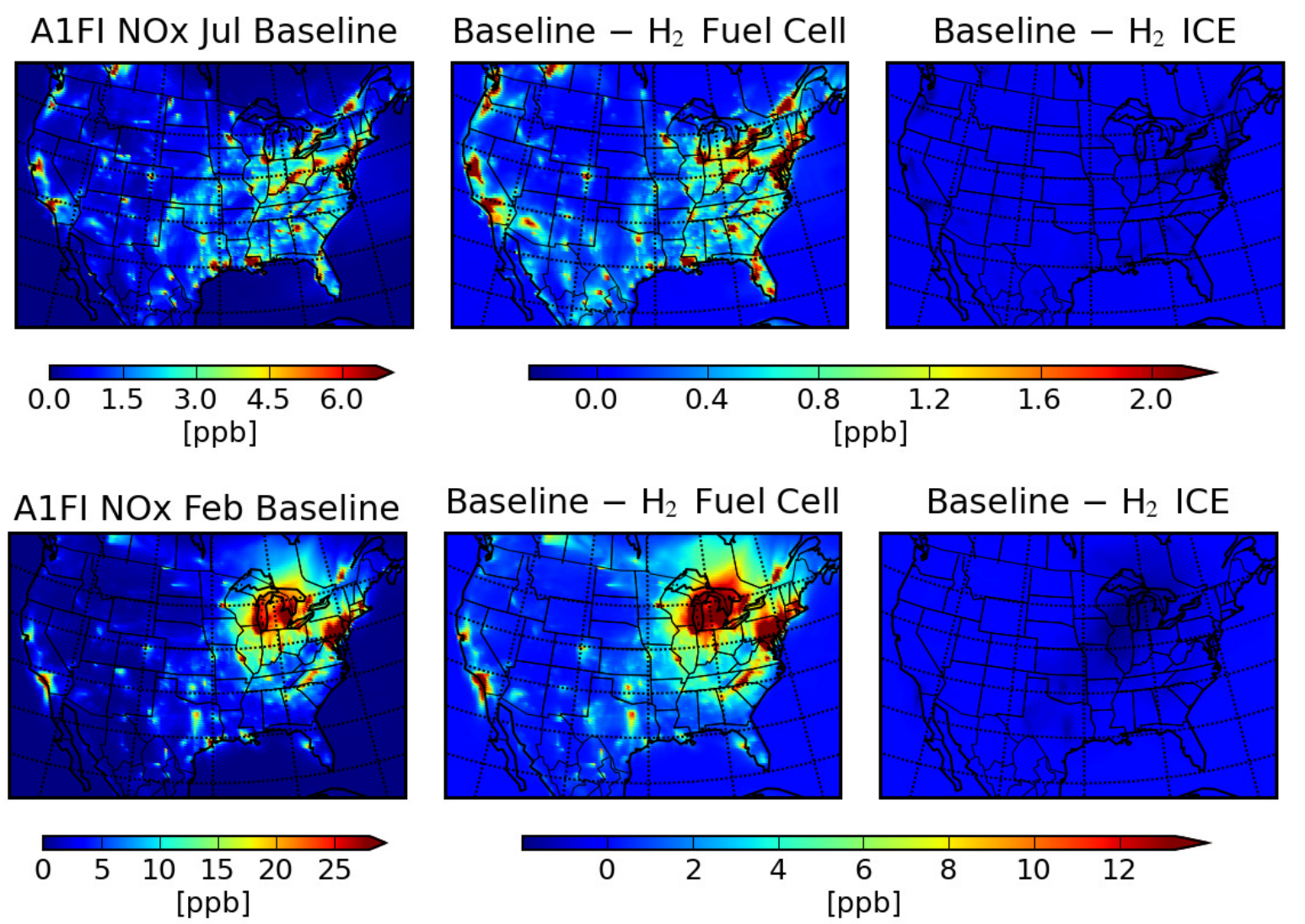

Figure 15. Monthly average NOx concentrations for July (top) and Feb (bottom) for the A1Fi scenario across the contiguous United States. Each row contains the Baseline Case (left), difference between the Baseline and $\mathrm{H}_{2}-\mathrm{FC}$ scenario (center), and difference between the Baseline and $\mathrm{H}_{2}$-ICE scenario (right). Data are averaged over the lowest three model levels $(\sim 250 \mathrm{~m})$. Note that the scales are different between panels. 

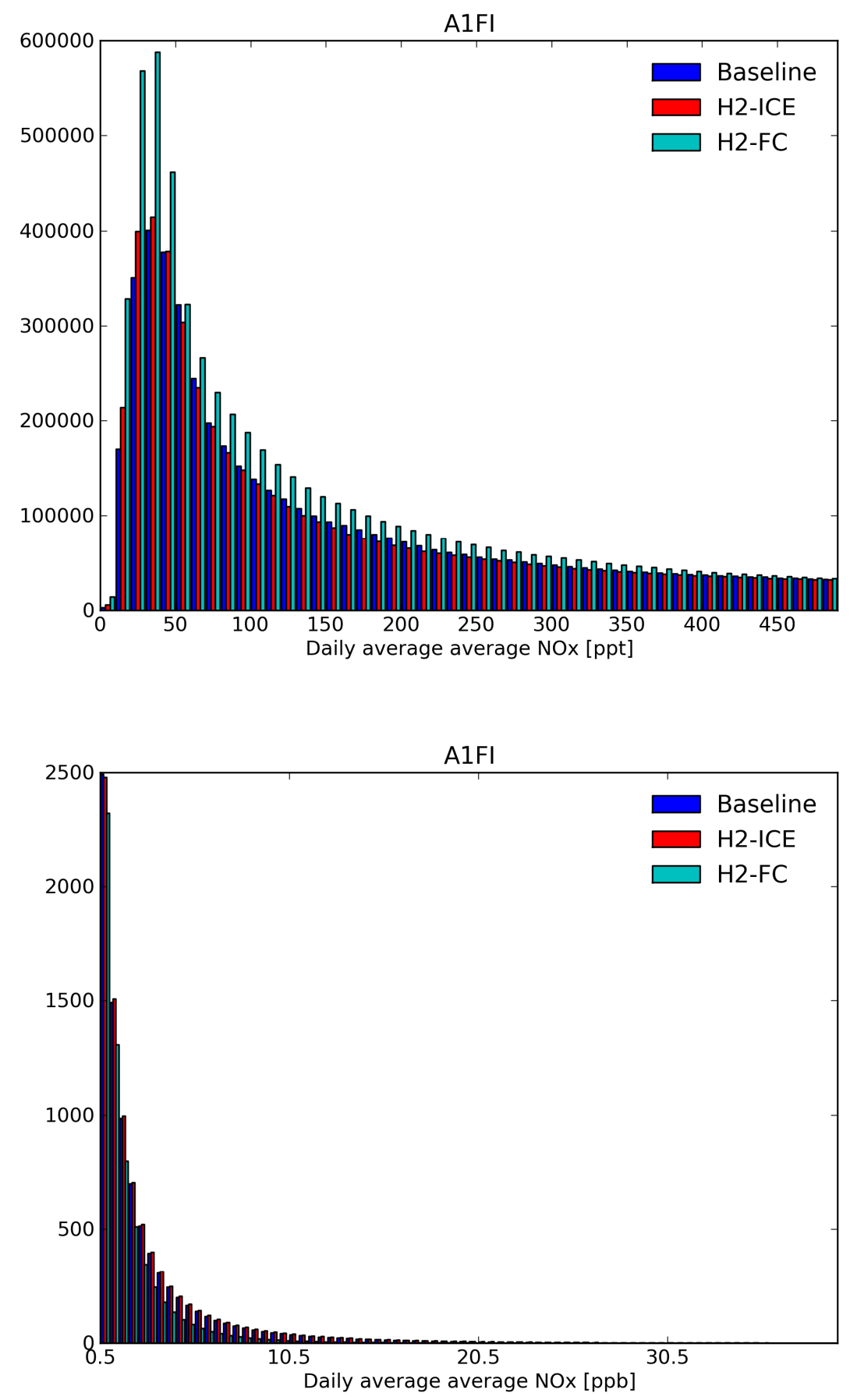

Figure 16. Distribution of simulated surface daily average NOx concentrations over 1 year for the A1Fi Baseline, $\mathrm{H}_{2}$-ICE, and $\mathrm{H}_{2}-\mathrm{FC}$ scenarios across the model domain. Top 
panel shows distribution from 0-500 ppt and the bottom panel shows the distribution from 0.5 to $40 \mathrm{ppb}$. Vertical axis in both panels is \#/ppt. Note the difference in scales.
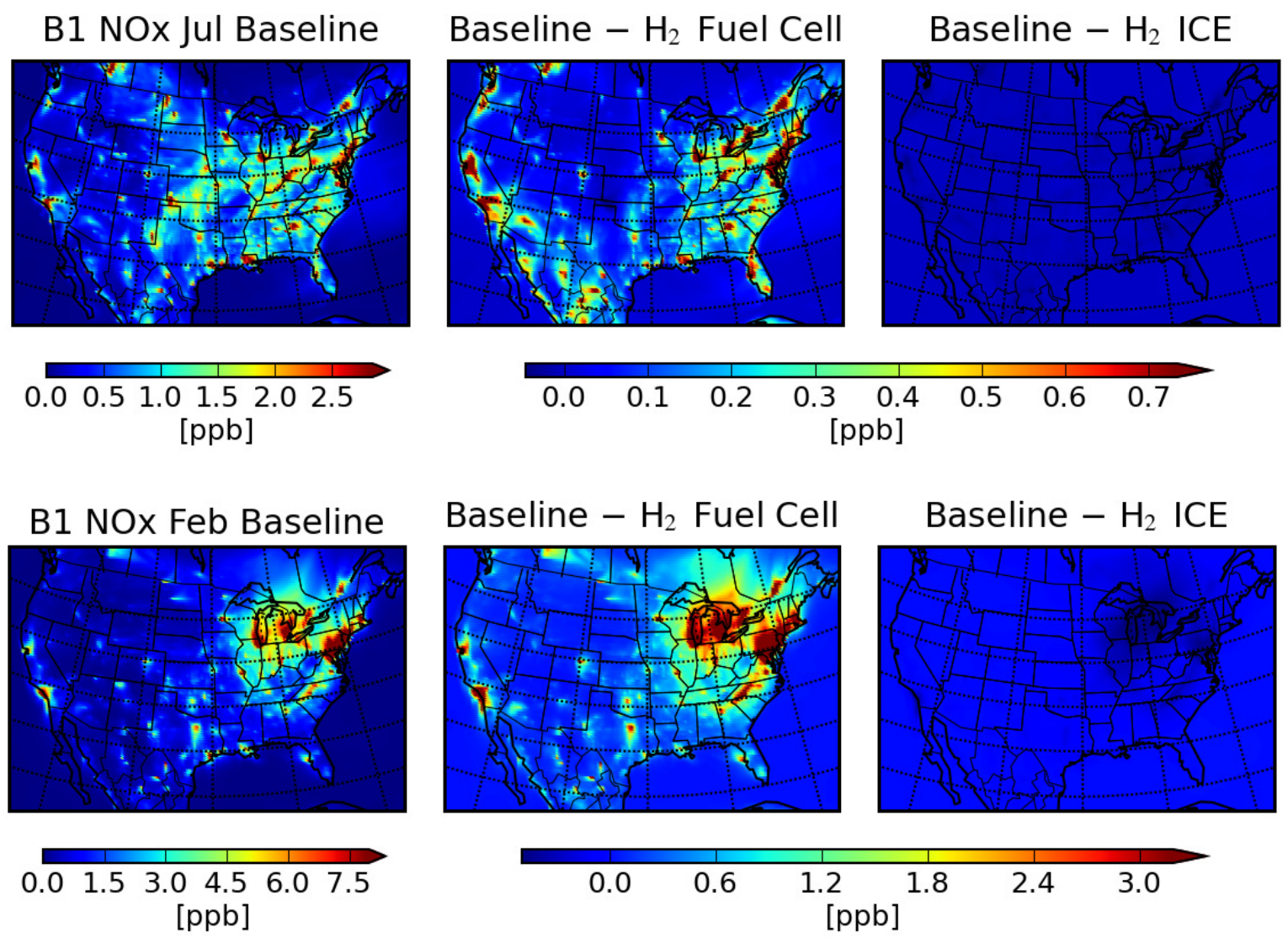

Figure 17. Monthly average NOx concentrations for July (top) and Feb (bottom) for the B1 scenario across the contiguous United States. Each row contains the Baseline Case (left), difference between the Baseline and $\mathrm{H}_{2}-\mathrm{FC}$ scenario (center), and difference between the Baseline and $\mathrm{H}_{2}$-ICE scenario (right). Data are averaged over the lowest three model levels $(\sim 250 \mathrm{~m})$. Note that the scales are different between panels. 

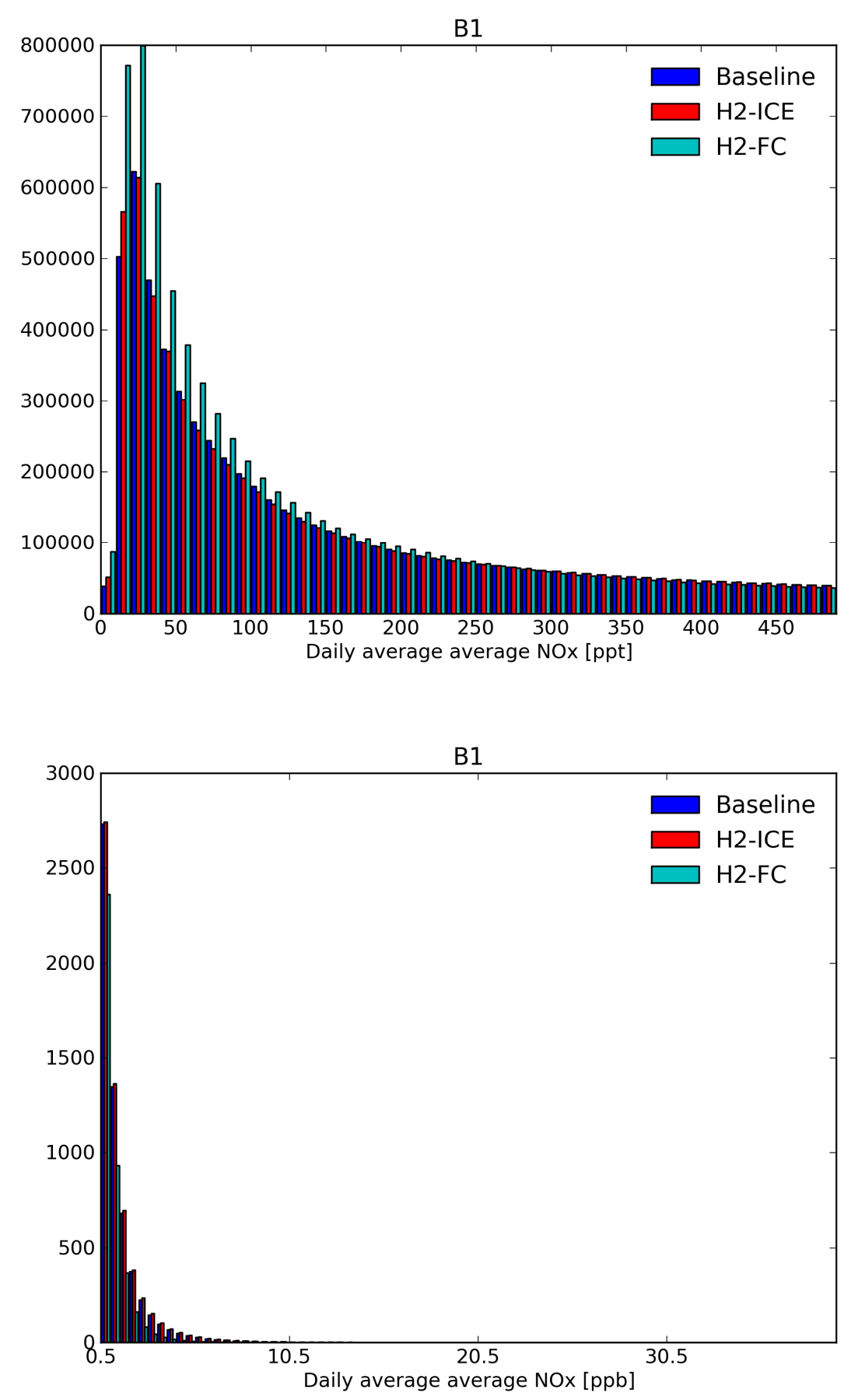

Figure 18. Distribution of simulated surface daily average NOx concentrations over 1 year for the $\mathrm{B} 1$ Baseline, $\mathrm{H}_{2}-\mathrm{ICE}$, and $\mathrm{H}_{2}-\mathrm{FC}$ scenarios across the model domain. Top 
panel shows distribution from 0-500 ppt and the bottom panel shows the distribution from 0.5 to $40 \mathrm{ppb}$. Vertical axis in both panels is \#/ppt. Note the difference in scales. 


\title{
Section 5 \\ 1) The Effect of Long Term $\mathrm{H}_{2}$ Enrichment on $\mathrm{H}_{2}$ uptake by Soils
}

\author{
David B. Layzell, Yanping Cen and Neal Scott \\ Institute for Sustainable Energy, Environment and Economy, University of Calgary, \\ Calgary, Alberta \\ Dept. Geography, Queen's University, Kingston, Ontario K7L 3N6
}

\section{Introduction}

Soil microbes play a major role in the global hydrogen $\left(\mathrm{H}_{2}\right)$ cycle, accounting for about $80 \%$ of the $\mathrm{H}_{2}$ removed from our current atmosphere. If leaks and fugitive emissions from a future $\mathrm{H}_{2}$ economy increase the atmospheric hydrogen concentration $\left[\mathrm{H}_{2}\right]$ above the current level $\left(0.55 \mathrm{ppm}_{2}\right)$, the soil microbes would be expected to respond by increasing their number or capacity for $\mathrm{H}_{2}$ consumption. Previous studies from our laboratory have shown that a five-fold increase in $\left[\mathrm{H}_{2}\right]\left(2.75 \mathrm{ppm} \mathrm{H}_{2}\right)$ causes an immediate 4 to 5 fold stimulation in the $\mathrm{H}_{2}$ deposition (i.e. uptake) rate (i.e. a first order relationship). However, after long-term (3-5 months) exposure to the higher $\left[\mathrm{H}_{2}\right]$, the $\mathrm{H}_{2}$ deposition rate increased to 7 to 12 times higher than that of soils exposed to air with current levels of $\mathrm{H}_{2}$.

To use this information in $\mathrm{H}_{2}$ cycle models, it will be important to understand the nature of the relationship between long term exposure to elevated $\left[\mathrm{H}_{2}\right]$ and the rate of $\mathrm{H}_{2}$ deposition in soils. This could be a linear, concave or convex relationship.

\section{Experimental Design:}

Twelve soil chambers were designed and built so that the $\left[\mathrm{H}_{2}\right]$ could be controlled in the gas space over the soil. Each of the rectangular plastic chambers held $2900 \mathrm{~cm}^{3}$ of soil with a surface area of $320 \mathrm{~cm}^{2}$ and $9 \mathrm{~cm}$ of soil depth. The soil was taken from a corn (Zea mays) field at the Ottawa Research Station of Agriculture and Agrifood Canada in Ottawa, Ontario.

The chambers were allocated into the following three $\mathrm{H}_{2}$ treatments with four chambers per treatment:

Ambient: $0.47 \pm 0.02 \mathrm{ppm} \mathrm{H}_{2}$

Medium: $1.38 \pm 0.03 \mathrm{ppm} \mathrm{H}_{2}$

High: $2.48 \pm 0.04 \mathrm{ppm} \mathrm{H}_{2}$

The $\mathrm{H}_{2}$ concentrations in the inflow and exhaust gas streams for each chamber were monitored over the 243 days of treatment and the results combined with information on the flow rate to calculate the rate of $\mathrm{H}_{2}$ deposition. Every few days during the treatment period, the chambers were weighted and water added to bring the weight (and the soil water content) back to its initial value. 


\section{Results:}

After 67 days of soil exposure to air with $0.47,1.38$ or $2.48 \mathrm{ppm} \mathrm{H}_{2}$, a linear relationship was found between the $\mathrm{H}_{2}$ concentration and the rate of $\mathrm{H}_{2}$ uptake by the soil (Fig 1.1). However, after 114 or 243 days of exposure, a clear convex relationship was observed (Fig 1.1). When the results were expressed in terms of the relative $\mathrm{H}_{2}$ uptake rate, a similar pattern emerged (Fig. 1.2).

\section{Discussion / Conclusion}

The results reported here have important implications for modeling the role of soils in the feedback control over the atmospheric $\mathrm{H}_{2}$ concentration in a future $\mathrm{H}_{2}$ economy.

The convex relationship shown in Fig. 1.1 suggests that even a small enrichment in the atmospheric $\mathrm{H}_{2}$ concentration above ambient (say from 0.5 to $1.4 \mathrm{ppm}$ ), there would be a significant stimulatory effect on the $\mathrm{H}_{2}$ uptake by soils. However, above $1.4 \mathrm{ppm}_{2}$, the effect of $\mathrm{H}_{2}$ enrichment on $\mathrm{H}_{2}$ uptake by soils will be less than the effect of a similar $\mathrm{pH}_{2}$ increment below $1.4 \mathrm{ppm}$.

While these studies do not provide any evidence on the underlying mechanism, a number of simple explanations are possible. The most obvious is the potential for a limiting factor affecting the rate of $\mathrm{H}_{2}$ uptake in soil at $\mathrm{H}_{2}$ concentrations above $1.4 \mathrm{ppm}$.

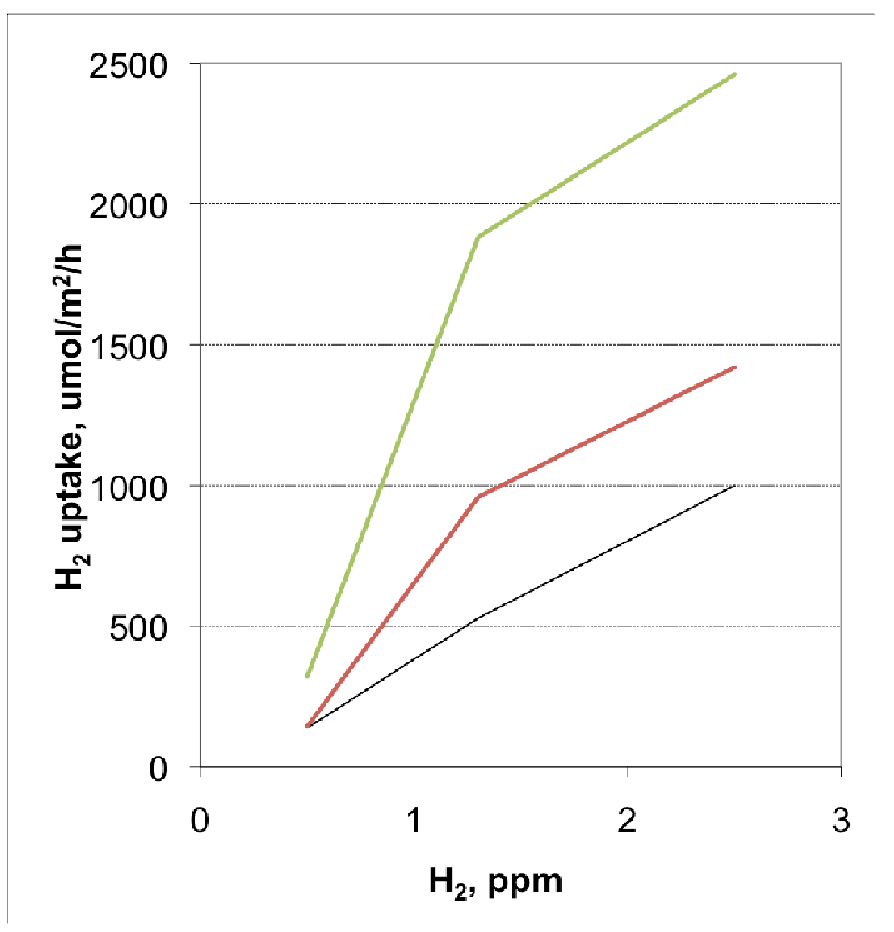


Fig 1.1 The effect of long term exposure of soils to a head space concentration of hydrogen on the rate of $\mathrm{H}_{2}$ uptake by the soil. 67days (Grey), 114 days (red), 243 days (Green)
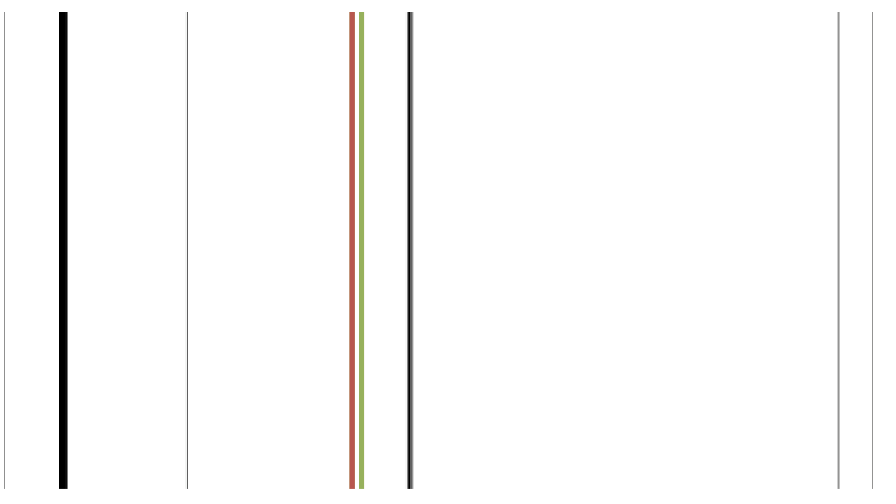

Fig 1.2 The effect of long term exposure of soils to a head space concentration of hydrogen on the relative rate of $\mathrm{H}_{2}$ uptake by the soil. 67days (Grey), 114 days (red), 243 days (Green) 


\title{
2) Impact of adaptive $\mathrm{H}_{2}$ soil sink on atmospheric $\mathrm{H}_{2}$ concentrations in a future society with an $\mathrm{H}_{2}$-based road transportation sector
}

\author{
Dong Wang, Wenjing Jia, Seth Olsen, Don Wuebbles
}

University of Illinois, Urbana Champaign

It is not well understood how soil microbes, which are the most important sink of atmospheric $\mathrm{H}_{2}$, will respond to increased atmospheric $\mathrm{H}_{2}$ concentrations in a future society with a hydrogen-based road transportation sector. Recent laboratory studies as part of this project support the hypothesis that soil microbes will adapt to elevated atmospheric $\mathrm{H}_{2}$ concentration by increasing their $\mathrm{H}_{2}$ uptake non-linearly. Based on these laboratory results, we have carried out model simulations to evaluate the impact of this adaptation on atmospheric $\mathrm{H}_{2}$ concentrations in a future $\mathrm{H}_{2}$ society.

Our laboratory studies indicate that microbial adaptation to higher ambient $\mathrm{H}_{2}$ levels could have a large impact on the magnitude of the $\mathrm{H}_{2}$ soil sink in the future. Examining the impact of this adaptation is critical as it could have a large affect on future atmospheric $\mathrm{H}_{2}$ concentrations particularly for the high-emissions scenarios. Current results suggest that at the concentrations simulated for the A1FI 2050 Baseline scenario uptake would be approximately 2.5 times current values and roughly 4 times higher for the $2050 \mathrm{~A} 1 \mathrm{FI} \mathrm{H}_{2}$-FC and $\mathrm{H}_{2}$-ICE scenarios (Figure 2.1). This increase in the $\mathrm{H}_{2}$ soil sink could provide a strong negative feedback to increasing atmospheric $\mathrm{H}_{2}$ concentrations and could possibly mitigate some of the adverse stratospheric impacts of an $\mathrm{H}_{2}$ economy.

Figure 2.1, Laboratory study results of $\mathrm{H}_{2}$ uptake relative to the current value as a function of $\mathrm{H}_{2}$ ambient concentration. 
This adaptive uptake mechanism has been incorporated into the CAMChem tropospheric model and its impact on atmospheric concentrations will be evaluated for the A1FI $\mathrm{H}_{2}-$ FC 2050 scenario.

In the MOZART atmospheric chemistry transport model the $\mathrm{H}_{2}$ soil sink is represented by deposition velocity $\left(\mathrm{V}_{\mathrm{d}}\right)$ to the surface. In the standard configuration $\mathrm{V}_{\mathrm{d}}\left(\mathrm{H}_{2}\right)$ is assumed to be two times the $\mathrm{CO}$ deposition velocity $\left(\mathrm{V}_{\mathrm{d}}(\mathrm{CO})\right)$, a value supported by observations under current conditions. To simulate the enhanced $\mathrm{H}_{2}$ soil sink $\mathrm{V}_{\mathrm{d}}\left(\mathrm{H}_{2}\right)$ is assumed to be dependent on the near-surface $\mathrm{H}_{2}$ concentration as well as $\mathrm{V}_{\mathrm{d}}(\mathrm{CO})$. The $\mathrm{H}_{2}$ dependence is implemented by scaling the original $\mathrm{V}_{\mathrm{d}}\left(\mathrm{H}_{2}\right)$ by a factor determined from the laboratory studies (Table 2.1). The model simulation was carried out for the A1FI-FC scenario which has the largest increase in atmospheric $\mathrm{H}_{2}$ concentration.

Table 2.3. Deposition velocity scale factor

\begin{tabular}{ll}
\hline $\begin{array}{l}\text { Range of }\left[\mathrm{H}_{2}\right] \\
{[\mathrm{ppm}]}\end{array}$ & Scale factor \\
\hline $\mathrm{H}_{2} \leq 0.5$ & $2.0^{*} \mathrm{H}_{2}$ \\
$0.5<\mathrm{H}_{2} \leq 1.3$ & $6.6 *\left(\mathrm{H}_{2}-0.5\right)+1.0$ \\
$\mathrm{H}_{2}>1.3$ & $2.1 *\left(\mathrm{H}_{2}-1.3\right)+6.28$ \\
\hline
\end{tabular}

Preliminary results indicate that soil microbe adaptation to elevated ambient $\mathrm{H}_{2}$ concentrations will decrease tropospheric $\mathrm{H}_{2}$ concentrations by more than $0.2 \mathrm{ppm}$ ( $20 \%$ ) relative to the non-adaptation case (Figure 2.2). The $\mathrm{H}_{2}$ concentration decrease extends into the stratosphere through the tropical upwelling, resulting in a pattern with a larger decrease in the tropics and a smaller decrease in higher latitudes at each altitude level in the stratosphere (Figure 2.2). The reduction in the Northern Hemisphere is larger than that in the Southern Hemisphere, with the largest absolute reduction appearing in the boundary layer in the northern mid-latitudes. This asymmetry reflects the overwhelming impact of soils on the continents of the northern hemisphere on global $\mathrm{H}_{2}$ budget. 

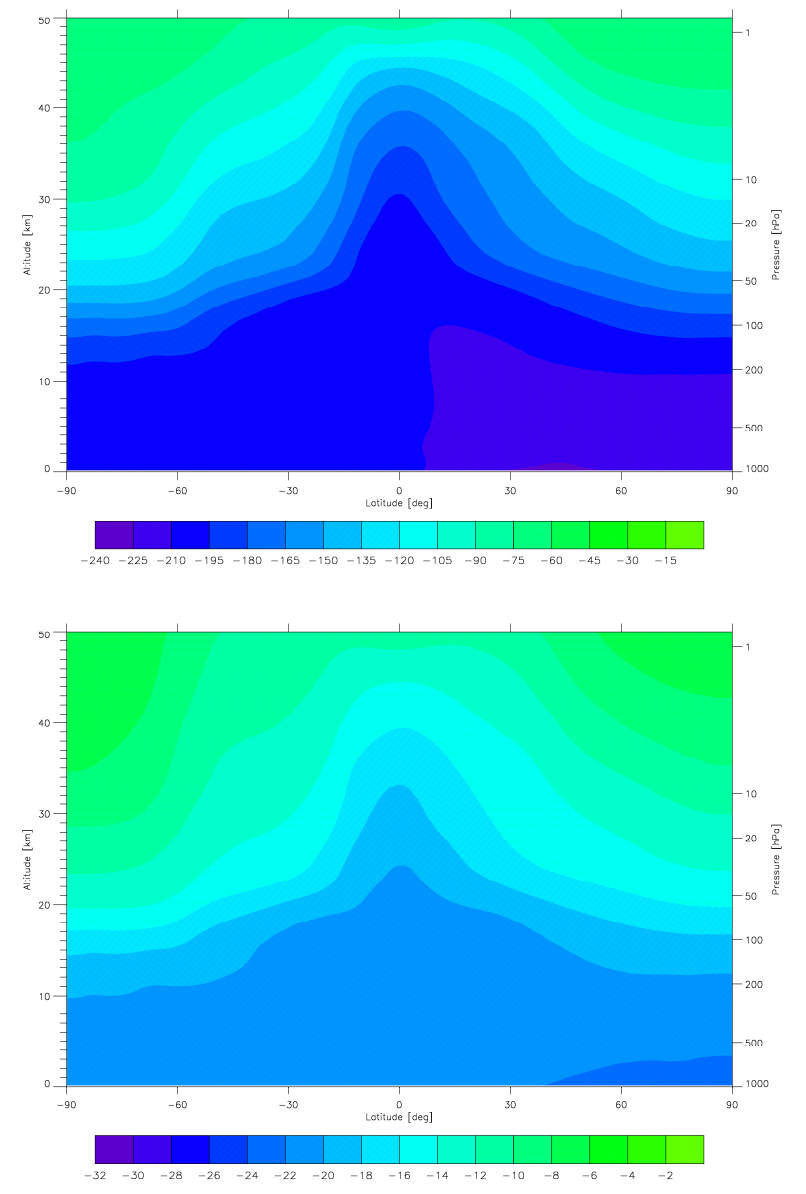

Figure 2.2 Absolute [ppb] (left) and relative [\%] (right) reduction of atmospheric $\mathrm{H}_{2}$ concentration with soil microbe adaptation compared to that without adaptation for the A1FI $\mathrm{H}_{2}$-FC scenario. 


\title{
Section 6 \\ Integrated Assessment Model for a Hydrogen-Based Road Transportation Sector
}

\author{
Seth Olsen, Dong Wang, Wenjing Jia, and Don Wuebbles \\ University of Illinois, Urbana Champaign
}

\section{Introduction}

The goal of the integrated assessment model (IAM) presented here is to facilitate the quick and easy assessment of the potential impacts of a transition to a $\mathrm{H}_{2}$-based transportation sector. Additionally, it will allow further analysis of the likely $\mathrm{H}_{2}$, greenhouse gases and criteria pollutant concentration changes (increases and/or decreases) arising from a developing global $\mathrm{H}_{2}$ infrastructure, including the ability to quantify the potential impacts of different market penetration scenarios. The IAM is based on a combination of results from detailed simulations of the impact of the emissions scenarios we developed (presented in a companion report) and other simplified models to assess other specific impacts. The outputs of the set of models and simulations are united, refined, and simplified to distill their essence to present the user with a single text file interface from which to make selections to create customized $\mathrm{H}_{2}$ scenarios. The user-defined variables includes information on depth of adoption of hydrogen as well as changes in the character of emissions. The IAM calculates the atmospheric perturbations of criteria pollutants and greenhouse gases and their impacts. The IAM focuses on changes in key atmospheric constituents that are of interest for this project including $\mathrm{H}_{2}$, $\mathrm{CO}_{2}$, column $\mathrm{O}_{3}$, tropospheric $\mathrm{O}_{3}, \mathrm{OH}$, and $\mathrm{CO}$, though the model could be expanded to include some other species or budget terms if necessary. The box-model IAM will synthesize our comprehensive modeling results as look up tables with interpolation. It will capture the nonlinearities in physics and chemistry to guide policy. However, it does not include dynamical feedbacks from climate change and larger scale regional airpollution. Additional detailed climate -chemistry modeling would be required to address those interactions.

\section{Methods}

The core model flows and computational modules of the IAM are depicted in Figure 1. There are core databases (emissions and concentrations). These are connected by three computational modules depicted by the numbered arrows: 1) calculates the atmospheric concentration changes of hydrogen and other species for the selected hydrogen penetration scenario; 2) calculates the radiative forcings (RF) from these concentration changes, and finally 3) calculates the temperature change from these RF changes. Each of these steps is described in more detail below. In this version, there is no active feedback capability for changes in air quality or climate to then affect concentrations further. 
The atmospheric changes for the user-defined scenario for all gases except $\mathrm{CO}_{2}$, (e.g., $\mathrm{H}_{2}$, $\mathrm{O}_{3}, \mathrm{OH}, \mathrm{CO}$, aerosols) are estimated by interpolation from archived results from our detailed simulation scenarios. The case libraries were developed using our state-of-the-art atmospheric chemistry-transport models CAM-Chem and MOZART and encompass a wide range of emissions scenarios as described in the companion emissions scenario report. Using these results as a basis, the atmospheric concentrations for the userdetermined scenario are calculated assuming a linear atmospheric response. The output from this calculation are available as changes in zonal annual means rather than changes in global means since many of these species are not uniformly distributed in the atmosphere. Regional concentration changes are output as annual averages at the surface. All of this data are then output as figures as well as data files. The linearized response assumption imposes certain restraints on the possible input scenarios. The requested scenario must be based on one of the core adoptions scenarios from the emissions scenarios, e.g., a combination of A1FI, or B1 and FC or ICE. Additionally the requested adoption scenario must be reasonably within the span of input scenarios used as a basis for the linearization in order to obtain scientifically justifiable results. Additionally the user scenario selection does not allow for regional variations. For most cases the restriction of this limitation is more than offset by the computational cost (weeks to months of computer run time) of a full atmospheric chemistry calculation.

The change in global mean $\mathrm{CO}_{2}$ concentration is calculated from estimates of the hydrogen-displaced $\mathrm{CO}_{2}$ emissions using the Bern carbon cycle model. The Bern carbon cycle model is a simplified parameter fit to a detailed terrestrial-ocean carbon cycle model (Plattner et al., 2001; Joos et al., 2001) and has been used extensively in the Intergovernmental Panel on Climate Change (IPCC) assessments (e.g., IPCC 2001). The radiative forcing change estimated from radiative efficiency factors and formulas relating atmospheric perturbations to their radiative forcings derived from complex models (e.g., IPCC 2001, IPCC 2007, Myhre et al., 1998). Finally, the temperature change response is calculated using the Shine et al. (2005) energy balance model that relates radiative forcing and climate sensitivity to global mean temperature response. It incorporates an upwelling-diffusion model for the ocean and resolves land and oceans separately in each hemisphere.

The tropospheric ozone radiative forcing is estimated directly from the ozone burden changes in the model and the specific radiative forcing. The aerosol radiative forcings are estimated from the current reported aerosol radiative forcings from IPCC [2007] for sulfate, nitrate, and black carbon (including the black carbon on snow albedo impact). From these current global average radiative forcings and the current model simulated aerosol burdens a specific forcing is calculated and this value is then scaled to the future aerosol burdens. Using relative changes in the radiative forcings in this manner reduces the significant uncertainties associated with calculations of absolute aerosol radiative forcing. It must be noted that there are large uncertainties associated with the aerosol radiative forcing estimates. The uncertainties associated with each forcing are often nearly as large as the value, e.g., the current RF for $\mathrm{BC}$ is $0.2+-0.15 \mathrm{~W} / \mathrm{m}^{2}$ and $0.1+-$ $0.1 \mathrm{~W} / \mathrm{m}^{2}$ for the BC snow albedo effect [IPCC, 2007]. The IPCC currently assigns a low level of scientific understanding to the aerosol RF, medium to the ozone RF, and high to $\mathrm{CO}_{2}$ RF. The stratospheric ozone specific RF is estimated from the current IPCC estimated RF due to stratospheric ozone loss $(-0.05+-0.1)$ and the change in 
stratospheric ozone column ( -10DU) for the same time period [WMO, 2006]. The methane $\left(\mathrm{CH}_{4}\right)$ concentration changes are estimated as in IPCC [1999] based on changes in the $\mathrm{CH}_{4}$ lifetime calculated from the CAM-Chem tropospheric impact simulations (Table 1.) with an amplification factor of 1.4 [e.g., IPCC 2001]. The small positive feedback of $\mathrm{CH}_{4}$ changes on global background tropospheric $\mathrm{O}_{3}$ is also included.

The time evolution of adoption is assumed to increase linearly from zero at the beginning of adoption, here taken to be 2005, to the end point of the user input percent adoption in 2050. Thus the non- $\mathrm{CO}_{2} \mathrm{RFs}$ increase linearly from zero in the start year (2005) to their maximum absolute value in 2050. The $\mathrm{CO}_{2}$ changes and $\mathrm{RFs}$ are calculated from the more detailed carbon cycle model. All of the timeseries are plotted as differences from the Baseline scenario. Radiative forcing and temperature changes are the differences from the Baseline scenario and not absolute values and thus represent the changes from the Baseline path due to the adoption of $\mathrm{H}_{2}$ technology.

The model is designed in a modular fashion such that the addition of new or updated modules and cases in the library will be relatively straightforward. This capability is particularly important since the simplified RF and temperature response modules will likely be updated as scientific understanding and computational power increase.

\section{Overview of Results for Scenarios}

Although the emphasis of the integrated assessment model is to provide a tool to allow DOE to evaluate scenarios of their choosing, here we present a short summary of the climate impact of the A1FI-FC, A1FI-ICE, B1-FC, and B1-ICE scenarios from the companion tropospheric assessment study.

For all scenarios there is a decrease in global average radiative forcing and temperature with the adoption of an $\mathrm{H}_{2}$ based road transportation scenario (Figures 2-5). The majority of the impact is caused by the decrease in atmospheric $\mathrm{CO}_{2}$ concentrations due to the displacement of fossil fuel usage for transportation. This benefit is only realized for $\mathrm{H}_{2}$ produced by non- $\mathrm{CO}_{2}$ emitting means, e.g., wind, solar, nuclear. The total 2050 radiative forcing changes are nearly $-0.6 \mathrm{~W} / \mathrm{m}^{2}$ (A1FI-FC), $-0.65 \mathrm{~W} / \mathrm{m}^{2}$ (A1FI-ICE), $-0.25 \mathrm{~W} / \mathrm{m}^{2}$ (B1-FC), and $-0.27 \mathrm{~W} / \mathrm{m}^{2}$ (B1-ICE). For comparison the total RF change from 2005 to 2050 is estimated to be $3.2 \mathrm{~W} / \mathrm{m}^{2}$ for the A1FI scenario and $1.77 \mathrm{~W} / \mathrm{m}^{2}$ for the B1 scenario [IPCC, 2001]. The corresponding total 2050 temperature changes are nearly 0.34 (A1FI-FC), -0.37 (A1FI-ICE), -0.09 (B1-FC), and -0.15 (B1-ICE). For comparison the total temperature change from 2005 to 2050 is estimated to be $1.62{ }^{\circ} \mathrm{C}$ for the A1FI scenario and $0.96{ }^{\circ} \mathrm{C}$ for the B1 scenario [IPCC, 2001].

The largest single contribution to the changes is from $\mathrm{CO}_{2}$ (the $\mathrm{CO}_{2}$ contribution is at least 4 times larger than any other contribution (Figures 2-5)). For all scenarios the sulfate $\left(\mathrm{SO}_{4}\right) \mathrm{RF}$ change is positive (a warming effect) but small due to the decrease in sulfate aerosols. The stratospheric ozone RF change is small and negative (a cooling effect) and the nitrate aerosol contribution is small and positive. While the relative contribution of the other species is mostly independent of the scenario, the $\mathrm{CH}_{4}$ depends critically on the technology scenario. For the fuel cell technology scenarios the $\mathrm{CH}_{4} \mathrm{RF}$ 
change is positive due to the increased $\mathrm{CH}_{4}$ lifetime while for the internal combustion engine (ICE) scenarios the $\mathrm{CH}_{4} \mathrm{RF}$ change is negative due to the decrease in $\mathrm{CH}_{4}$ lifetime in those scenarios. The dependence of the $\mathrm{CH}_{4} \mathrm{RF}$ change on scenario causes the overall decrease in RF to be larger for the ICE scenarios than for the FC scenarios. While this is desirable from a climate perspective it must be emphasized that air quality improved much more in the FC scenarios than in the ICE scenarios. The RF changes for soot and tropospheric ozone are negative for all scenarios though the decreases are larger for the FC scenarios.

Conclusions: Overall, the adoption of $\mathrm{H}_{2}$ as an energy carrier for road transportation will have a beneficial impact on climate reducing global average radiative forcings and surface temperature provided the hydrogen is produced without emitting $\mathrm{CO}_{2}$ to the atmosphere. This study indicates that there are some trade-offs to be addressed, e.g., the scenarios with the largest improvement from a climate perspective (ICE) and the scenarios with the largest improvement from an air quality perspective (FC) are not the same. It should also be emphasized that, as with the air quality improvements, the future growth scenario has a larger impact on future climate than adopting a $\mathrm{H}_{2}$ based road transportation sector with either FC or ICE technology. For example, even though the climate improvements are greater for the A1FI scenarios with the adoption of an $\mathrm{H}_{2}$ based road transportation sector, future climate change is still lower for any of the B1 future growth scenarios regardless of $\mathrm{H}_{2}$ adoption.

\section{IAM Scenario Selection and Use}

Here we describe the use of the model in detail and results for a sample scenario. Most of the scenario selection parameters for the IAM are located in the H2_IAM.py file. Editing of these files on Windows is easiest with wordpad or the idle editor with python. These are the parameters discussed here (see the technical documentation in the README file for additional details on modifying additional parameters). The base scenario is selected based on the 'Growth_Scenario' and 'Tech_Scenario' parameters. These parameters determine the base or starting point for the penetration scenario selection. The 'Growth_Scenario' may be either 'B1' or 'A1FI' and the 'Tech_Scenario' may be either 'FC' or 'ICE'. The 'Scenario_Scale' parameter determines the penetration of hydrogen as a road transportation fuel as a percentage and must be between 0 and 1.0. Note that if Scenario_Scale is 0.5 then it is assumed that $50 \%$ of the fuel is supplied as $\mathrm{H}_{2}$ and $50 \%$ is supplied traditional fossil fuel. Additional optional parameters are 'Scenario_Prefix' which will be used as a prefix for all output files in order to make it easier to differentiate different runs with different scenarios and 'OutDir' which is the directory in which to store the output files (this directory will be created if it does not already exist). 'SaveData' and 'SavePlots' are flags to determine whether the data and plots will be written to files. Since plotting the data requires some (though not much) additional time. For this example we have chosen Growth_Scenario=A1FI, Tech_Scenario=FC, ScenarioPrefix='A1FI_FC', and Scenario_Scale=1.0 with the SaveData and SavePlots flags set to 'True'. 
When the model is run the following files are written to the output directory.

A1FI_FC_emissions.txt: which contains the emissions of $\mathrm{H} 2, \mathrm{CO}, \mathrm{NO}, \mathrm{SO} 2, \mathrm{BC}$, and NMVOC for this scenario.

A1FI_FC_CO_latlon.png A1FI_FC_O3_col_latlon.png A1FI_FC_O3_zonal.png A1FI_FC_CO_zonal.png A1FI_FC_O3_col_strat_latlon.png A1FI_FC_OH_zonal.png A1FI_FC_H2_latlon.png A1FI_FC_O3_col_trop_latlon.png

A1FI_FC_PM25_latlon.png

A1FI_FC_H2_zonal.png A1FI_FC_O3_latlon.png A1FI_FC_RF.png

A1FI_FC_dT.png

These files contain plots of the resulting baseline scenario and differences between the Baseline and selected scenario.

A1FI_FC_CO_latlon_base.txt A1FI_FC_CO_zonal_base.txt A1FI_FC_H2_latlon_base.txt A1FI_FC_H2_zonal_base.txt A1FI_FC_O3_col_latlon_base.txt A1FI_FC_O3_col_strat_latlon_base.txt A1FI_FC_CO_latlon_diff.txt A1FI_FC_CO_zonal_diff.txt A1FI_FC_H2_latlon_diff.txt A1FI_FC_H2_zonal_diff.txt A1FI_FC_O3_col_latlon_diff.txt A1FI_FC_O3_col_strat_latlon_diff.txt A1FI_CO2_dT.txt
A1FI_FC_O3_col_trop_latlon_base.txt

A1FI_FC_O3_latlon_base.txt

A1FI_FC_O3_zonal_base.txt

A1FI_FC_OH_zonal_base.txt

A1FI_FC_PM25_latlon_base.txt
A1FI_FC_O3_col_trop_latlon_diff.txt

A1FI_FC_O3_latlon_diff.txt

A1FI_FC_O3_zonal_diff.txt

A1FI_FC_OH_zonal_diff.txt

A1FI_FC_PM25_latlon_diff.txt

A1FI_FC_RF.txt

A1FI_FC_CO2.txt

These files contain the data used to make the plots described above and a description of the grid. 


\section{References}

IPCC 1999: Aviation and the Global Atmosphere, Prepared in collaboration with the Scientific Assessment Panel to the Montreal Protocol on Substances that Deplete the Ozone Layer, J.E.Penner, D.H.Lister, D.J.Griggs, D.J.Dokken, M.McFarland (Eds.), Cambridge University Press, UK. pp 373.

IPCC 2001: Climate Change 2001: Contribution of Working Group I to the Third Assessment Report of the Intergovernmental Panel on Climate Change (IPCC) J. T. Houghton, Y. Ding, D.J. Griggs, M. Noguer, P. J. van der Linden and D. Xiaosu (Eds.) Cambridge University Press, UK. pp 944.

IPCC, 2007: Climate Change 2007: The Physical Science Basis. Contribution of Working Group I to the Fourth Assessment Report of the Intergovernmental Panel on Climate Change [Solomon, S., D. Qin, M. Manning, Z. Chen, M. Marquis, K.B. Averyt, Tignor and H.L. Miller (eds.)]. Cambridge University Press, Cambridge, United Kingdom and New York, NY, USA, 996 pp.

Joos, F., I. Prentice, S. Sitch, R. Meyer, G. Hooss, G. Plattner, S. Gerber, K. Hasselmann, Global warming feedbacks on terrestrial carbon uptake under the IPCC emission scenarios, Global Biogeochemical Cycles, 15, 891- 907, 2001.

Myhre, G., E.J. Highwood, K.P. Shine, and F. Stordal: New estimates of radiative forcing due to well mixed greenhouse gases. Geophysical Research Letters., 25, 2715-2718, 1998.

Plattner, G.-K., F. Joos, T.F. Stocker, and O. Marchal, Feedback mechanisms and sensitivities of ocean carbon uptake under global warming, Tellus, 53B, 564-592, 2001.

Shine, K., J. Fuglestvedt, K. Hailemariam, N. Stuber, Alternatives to the Global Warming Potential for Comparing Climate Impacts of Emissions of Greenhouse Gases, Climatic Change, 68, 3, 281-302, 2005.

WMO (World Meteorological Organization), Scientific Assessment of Ozone Depletion: 2006, Global Ozone Research and

Monitoring Project—Report No. 50, 572 pp., Geneva, Switzerland, 2007. 
Table 1. $\mathrm{CH}_{4}$ lifetimes [years] for the CAM-Chem $2050 \mathrm{H}_{2}$ based road transportation sector impact assessment model simulations.

\begin{tabular}{|c|c|c|}
\hline & A1FI & B1 \\
\hline 2050 Baseline & 9.1 & 8.3 \\
\hline 2050 FC & 9.7 & 8.8 \\
\hline 2050 ICE & 8.7 & 8.1 \\
\hline
\end{tabular}




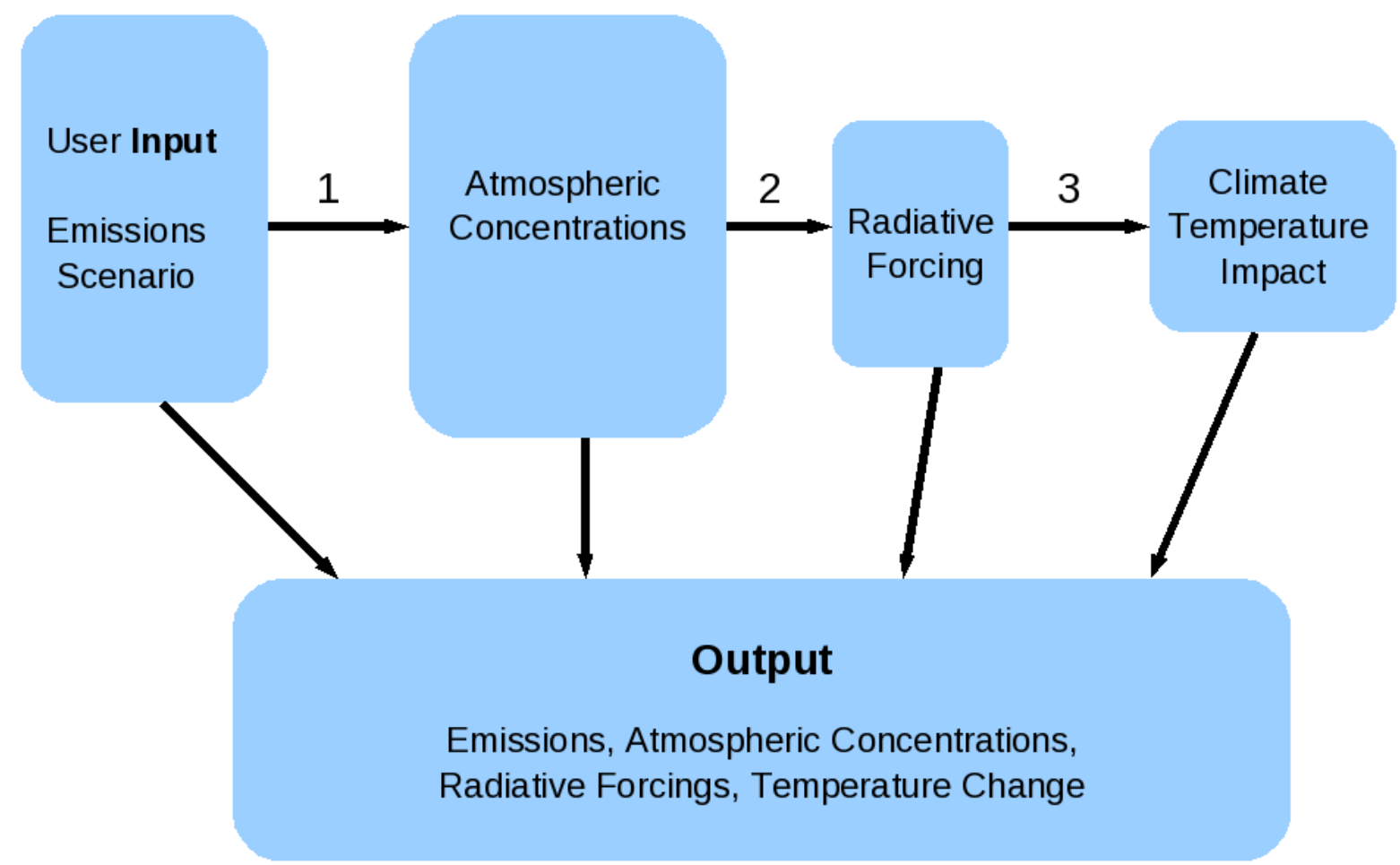

Figure 1. Schematic diagram of the hydrogen Integrated Assessment Model. The boxes represent the levels of data and the numbered arrows represent the computational modules that calculate the next level of data from the previous one as described in the text.
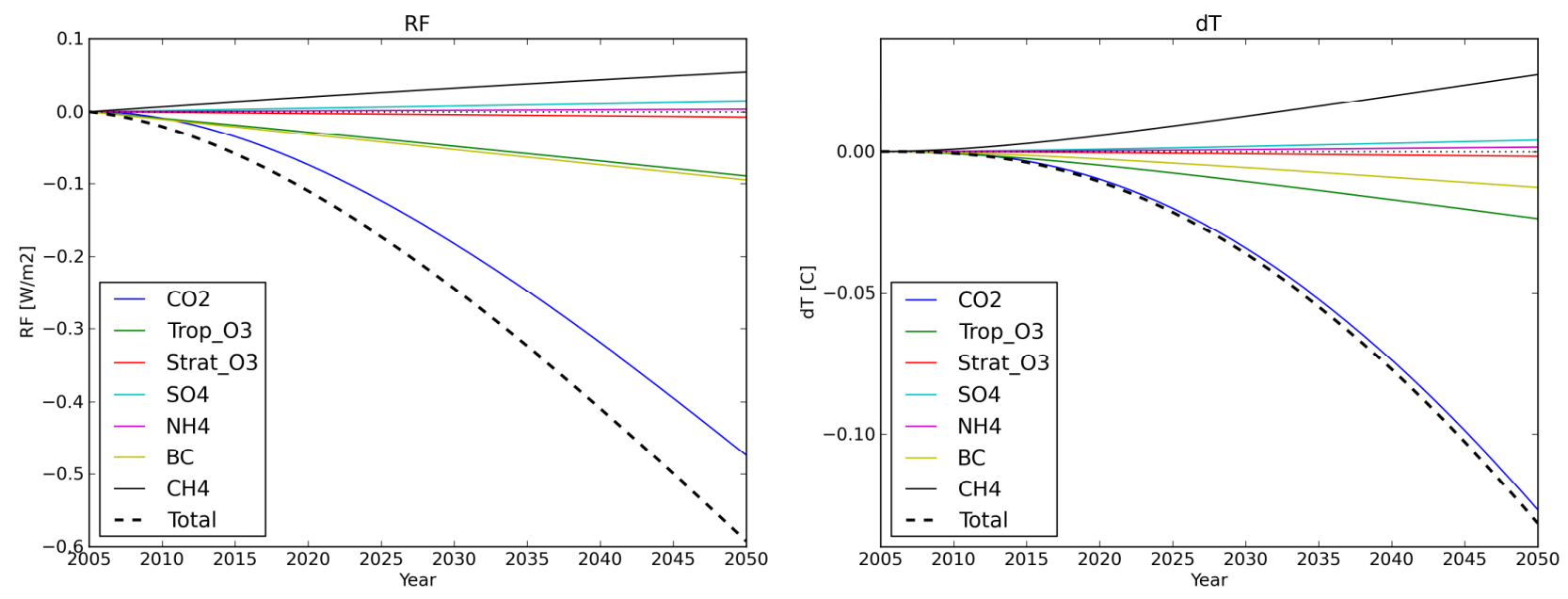
Figure 2. Radiative forcing (left) and temperature (right) changes due to the adoption of an $\mathrm{H}_{2}$ powered road transportation sector for the A1FI-FC scenario.
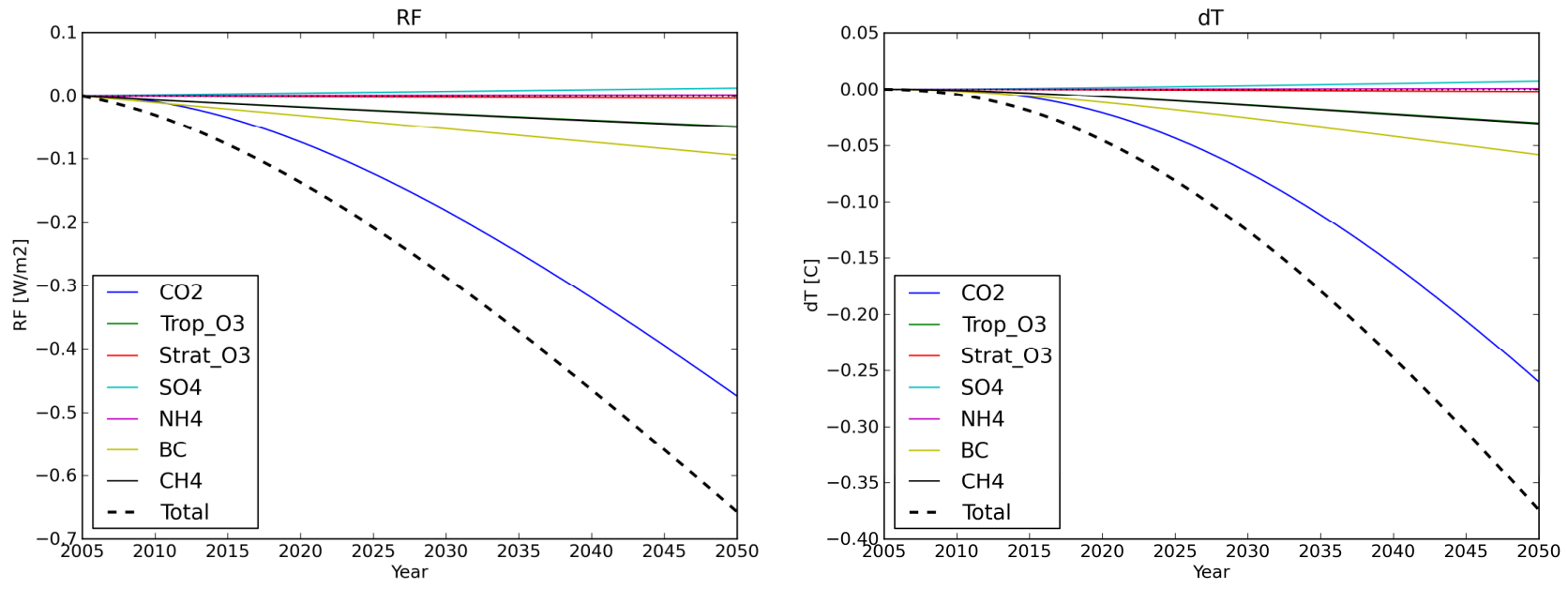

Figure 3. Radiative forcing (left) and temperature (right) changes due to the adoption of an $\mathrm{H}_{2}$ powered road transportation sector for the A1FI-ICE scenario.
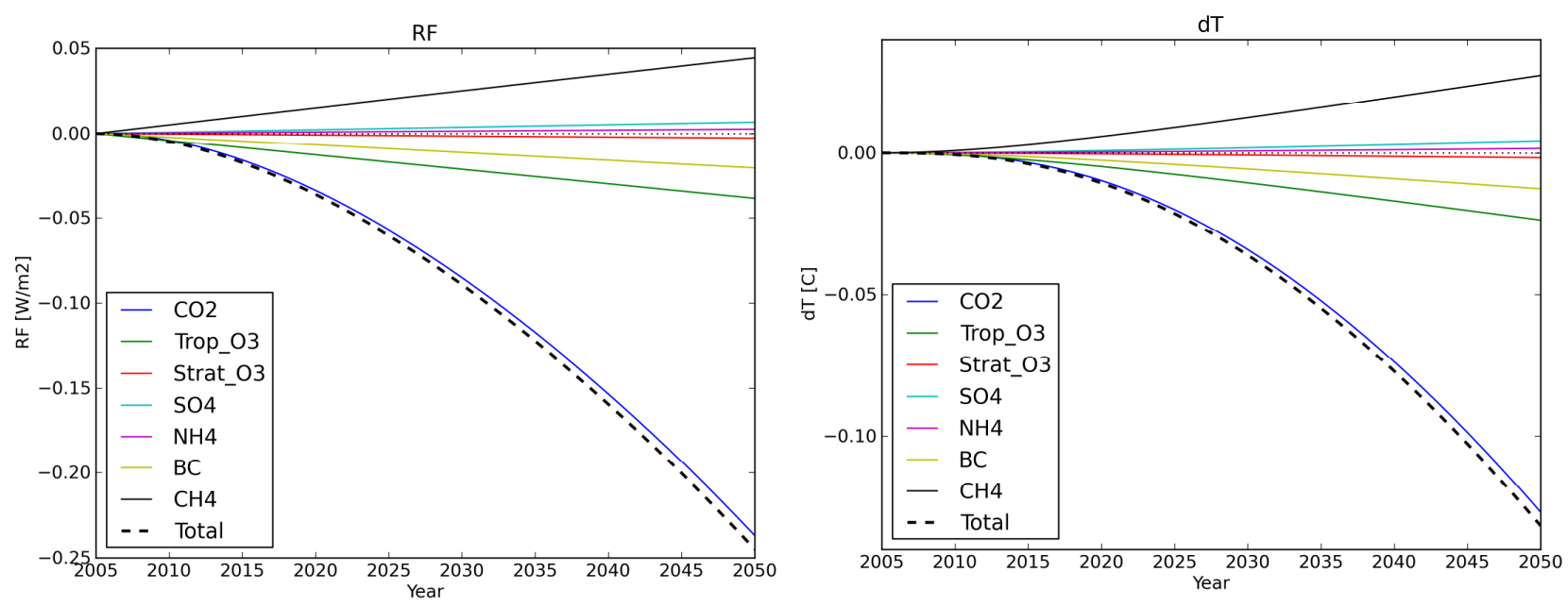

Figure 4. Radiative forcing (left) and globally-averaged temperature (right) changes due to the adoption of an $\mathrm{H}_{2}$ powered road transportation sector for the B1-FC scenario. 

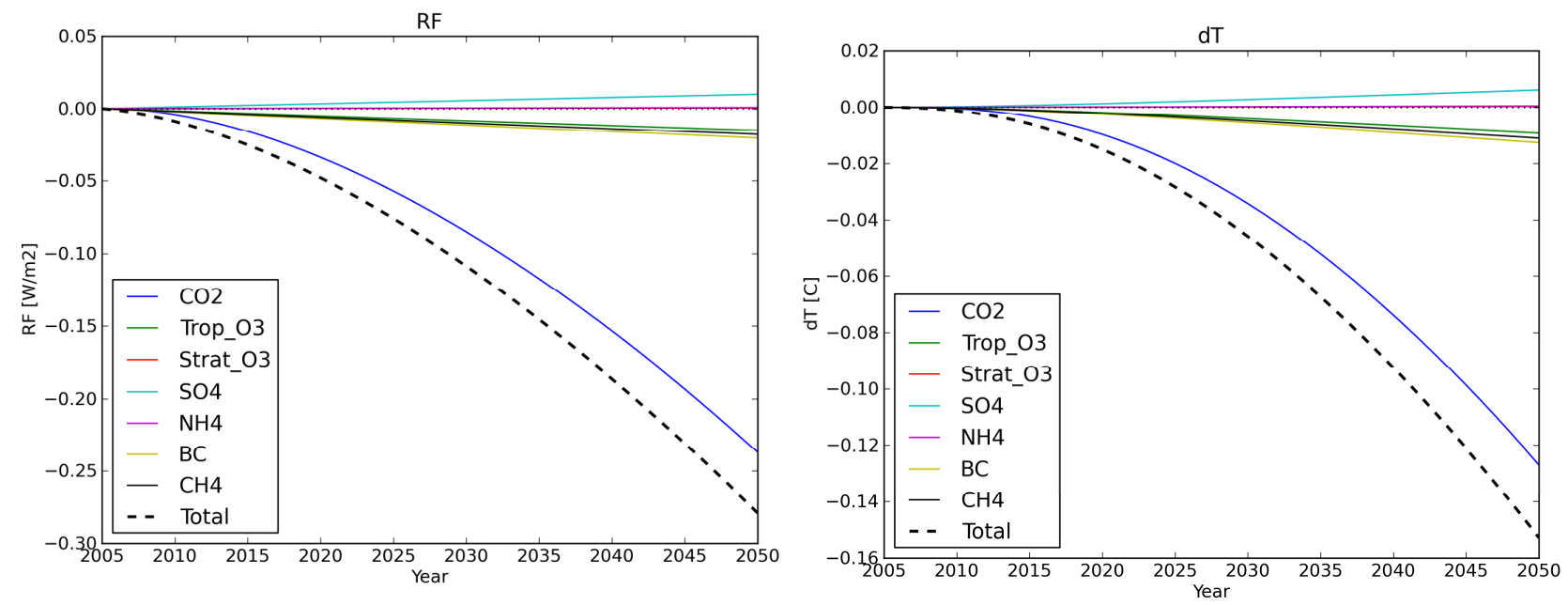

Figure 5. Radiative forcing (left) and globally-averaged temperature (right) changes due to the adoption of an $\mathrm{H}_{2}$ powered road transportation sector for the B1-ICE scenario. 


\title{
Section 7
}

\section{$\mathrm{H}_{2}$ Production Oxygen Plume Risk Assessment}

\author{
Dong Wang, Don Wuebbles and Angus Rockett \\ University of Illinois, Urbana-Champaign
}

In a hydrogen economy, oxygen $\left(\mathrm{O}_{2}\right)$ can be a by-product of molecular hydrogen $\left(\mathrm{H}_{2}\right)$ production, if $\mathrm{H}_{2}$ is generated from electrolysis of water. The produced oxygen, if not collected for other use is expected to be released to the atmosphere. Increased oxygen concentration can facilitate fire spread. Thus it is of interest to examine the expected increase in oxygen content around a large-scale electrolysis facility. Here we analyze this potentially hazardous effect by estimating the increased $\mathrm{O}_{2}$ concentration near an $\mathrm{H}_{2}$ plant with an assumed emission rate using a Gaussian plume model.

\section{Estimated emission rate}

As a "worst-case" scenario the $\mathrm{O}_{2}$ release rate from 100 large $\mathrm{H}_{2}$ plants. It is assumed that all energy needed by the U.S. for road transport is provided by $\mathrm{H}_{2}$. The energy demand by total U.S. transportation system for year 2002 was estimated to be 26.5 Quads [LLNL]. The future road transportation part is assumed to be roughly equal to this value.

To meet such a demand, $890 \mathrm{GJ}\left(1 \mathrm{GJ}=1 \times 10^{9} \mathrm{Joules}\right)$ must be stored in the form of $\mathrm{H}_{2}$ per second. Taking the energy density of $\mathrm{H}_{2}$ (142 MJ/kg, Bossel, Ulf and Eliasson [2003]) into account, $6200 \mathrm{~kg} \mathrm{sec}^{-1} \mathrm{H}_{2}$ must be produced. The corresponding $\mathrm{O}_{2}$ production is $\sim 5 \times 10^{4} \mathrm{~kg} \mathrm{sec}^{-1}$. Assuming there are $100 \mathrm{H}_{2}$ factories with equal production capacities distributed throughout the U.S, each will release $500 \mathrm{~kg} \mathrm{sec}^{-1} \mathrm{O}_{2}$. This oxygen is assumed to be released from an $80 \mathrm{~m}$ high stack.

There is no specific threshold for a major increase in fire spread. As oxygen concentration increases fire spread increases both because more oxidizer is available and because a fuel/oxidizer mixture closer to stoichiometry is more readily achieved so the fire burns hotter near the surface, accelerating pyrolysis of the surface. A significant increase in fire spread can be expected from a 5 volume \% increase in oxygen concentration, therefore we take this as a threshold for a significant impact of oxygen from a large-scale electrolyzer. Under standard temperature and pressure conditions, a 5 volume $\%$ increase in oxygen concentration is equal to $70 \mathrm{~g} \mathrm{~m}^{-3}$. This constitutes our expected zone of fire safety risk around an electrolyzer. 


\section{Gaussian plume model}

Snap-shot $\mathrm{O}_{2}$ plume concentrations downwind of an $\mathrm{O}_{2}$ source in a realistic atmosphere are difficult to predict precisely in a timely fashion because of instantaneous turbulence, ubiquitous in the mixing-layer atmosphere (Fig. 1, left). However, according to observations, the time-averaged pollutant concentration generally obeys a Gaussian distribution in the horizontal and vertical directions in the plane normal to the prevailing wind direction (Fig. 1, right). Thus the Gaussian plume model (Fig. 2) has been developed, and has been widely used since the 1940s.
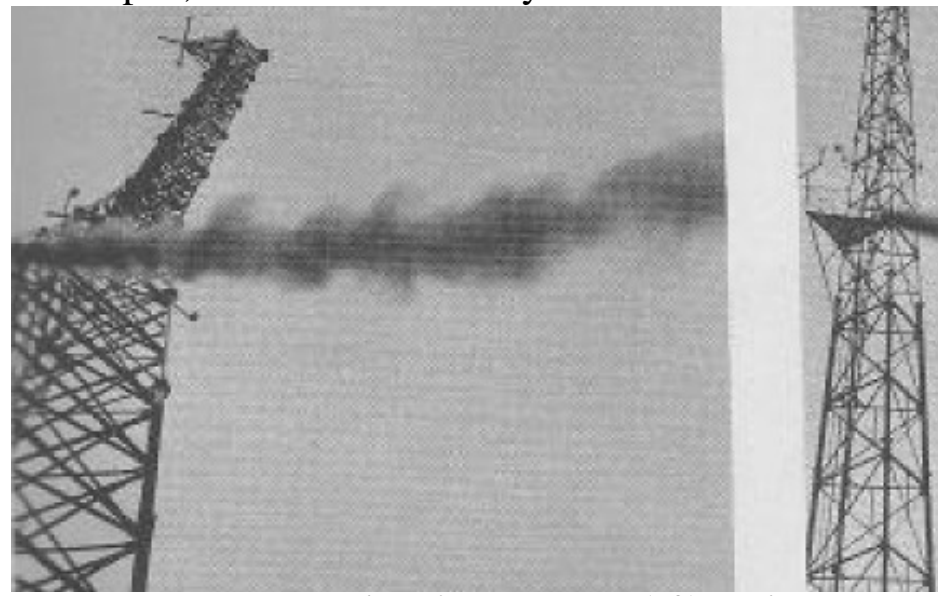

Figure 2. Instantaneous (left) and time-averaged (right) plume shape. Source: Blade et al., Meteorology and Atomic Energy, 1968

Based on a Gaussian distribution, concentrations of a pollutant in the stack plume can be described by the following equation,

$$
C=\frac{Q}{2 \pi u \sigma_{y} \sigma_{z}} \bullet \exp \left(-\frac{y^{2}}{2 \sigma_{y}^{2}}\right) \cdot\left[\exp \left(-\frac{(z-H)^{2}}{2 \sigma_{z}^{2}}\right)+\exp \left(-\frac{(z+H)^{2}}{2 \sigma_{z}^{2}}\right)\right]
$$

Where $\mathrm{C}$ is the oxygen concentration, $\mathrm{Q}$ is the oxygen emission rate, $\mathrm{u}$ is the background wind speed, $\mathrm{H}$ is the stack height, and $\sigma_{y}$ and $\sigma_{z}$ are horizontal and vertical standard deviations of the emission distribution.

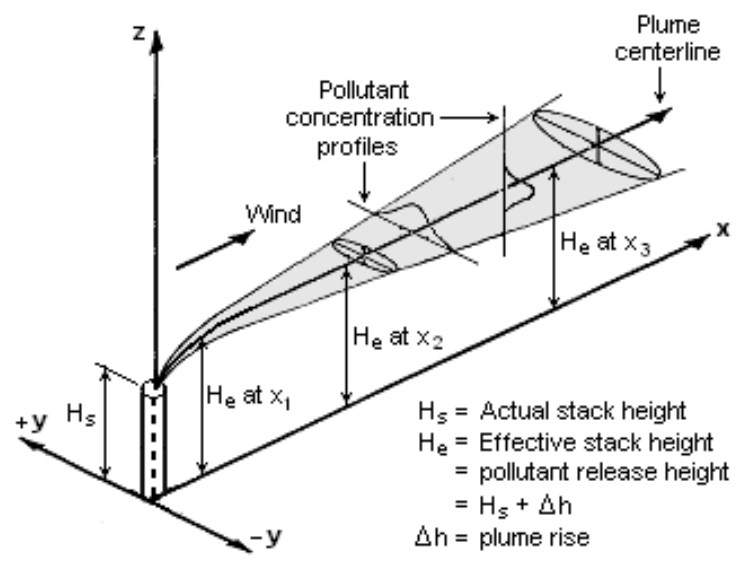

Figure 2. A visualization by Milton Beychok of a buoyant Gaussian air pollutant dispersion plume. The oxygen plume is not expected to be buoyant but the general shape is expected to be the same in form but closer to the ground. 
$\sigma_{y}$ and $\sigma_{z}$ are functions of distance to the emission source and stability classes (Table 1). The main mechanisms to dilute the pollutant plume are entrainment and mixing of fresh ambient air into the plume. The intensity of these processes is determined by the amount of atmospheric turbulence present in the mixing layer. Thus, classifying atmospheric stability is helpful in describing intensity of atmospheric dispersion. The judging criteria for Pasquill stability classes are listed in Table 2.

Table 1. The Pasquill stability classes

\begin{tabular}{cc}
\hline Stability class & Definition \\
\hline A & Very unstable \\
B & Unstable \\
C & Slightly unstable \\
D & Neutral \\
E & Slightly stable \\
F & Stable \\
\hline
\end{tabular}

When there are inversions present, which act like a lid aggravating the concentration in the mixing layer, the Gaussian equation can be modified as the following,

$$
C=\frac{Q}{2 \pi u \sigma_{y} \sigma_{z}} \bullet \exp \left(-\frac{y^{2}}{2 \sigma_{y}^{2}}\right) \cdot \sum_{m=-\infty}^{+\infty}\left[\exp \left(-\frac{(z-H+2 m L)^{2}}{2 \sigma_{z}^{2}}\right)+\exp \left(-\frac{(z+H+2 m L)^{2}}{2 \sigma_{z}^{2}}\right)\right]
$$

where $\mathrm{L}$ is the bottom height of the lowest inversion layer. Treatment of the problem with an assumed inversion layer both presents a "worst-case" condition and simply handles the non-buoyant plume.

Table 2. Classifying criteria for Pasquill stability classes

\begin{tabular}{cccccc}
\hline Surface wind speed & \multicolumn{2}{c}{ Daytime incoming solar radiation } & \multicolumn{2}{c}{ Nighttime cloud cover } \\
\hline $\mathrm{m} / \mathrm{s}$ & Strong & Moderate & Slight & $>50 \%$ & $<50 \%$ \\
\hline$<2$ & $\mathrm{~A}$ & $\mathrm{~A}-\mathrm{B}$ & $\mathrm{B}$ & $\mathrm{E}$ & $\mathrm{F}$ \\
$2-3$ & $\mathrm{~A}-\mathrm{B}$ & $\mathrm{B}$ & $\mathrm{C}$ & $\mathrm{E}$ & $\mathrm{F}$ \\
$3-5$ & $\mathrm{~B}$ & $\mathrm{~B}-\mathrm{C}$ & $\mathrm{C}$ & $\mathrm{D}$ & $\mathrm{E}$ \\
$5-6$ & $\mathrm{C}$ & $\mathrm{C}-\mathrm{D}$ & $\mathrm{D}$ & $\mathrm{D}$ & $\mathrm{D}$ \\
$>6$ & $\mathrm{C}$ & $\mathrm{D}$ & $\mathrm{D}$ & $\mathrm{D}$ & $\mathrm{D}$ \\
\hline
\end{tabular}

\section{Model results and discussion}

Emitted $\mathrm{O}_{2}$ plume concentrations were calculated for various combinations of stability classes, background wind speeds and inversion layers present. Detailed $\mathrm{O}_{2}$ concentrations are plotted in the horizontal plane at stack height and vertical cross-section in Appendices I and II.

When inversion layers are present, the $\mathrm{O}_{2}$ plume cannot disperse into the atmosphere and is confined in the mixing layer. Thus, the $\mathrm{O}_{2}$ concentration is larger than without inversions. The effect of inversions is apparent by comparing Appendices I and II. 
Under each specific stability class, the $\mathrm{O}_{2}$ plume concentration decreases with increasing background wind. This is easy to understand because dispersion is stronger with larger wind speed. In the extreme case, under stability class $\mathrm{F}$ with a background wind speed of $1 \mathrm{~m} \mathrm{~s}^{-1}$, the $70 \mathrm{~g} \mathrm{~m}^{-3}$ critical concentration extends to 1600 meters downwind of the source. When inversion layer is at $100 \mathrm{~m}$ aloft, this value can be as far as 1800 meters.

At the same background wind speed, the $\mathrm{O}_{2}$ concentration increases with increasing stability. Meanwhile, the horizontal dimension of increased fire risk increases significantly. The effect of atmospheric stability on $\mathrm{O}_{2}$ plume dispersion is illustrated in Figures 3 and 4.
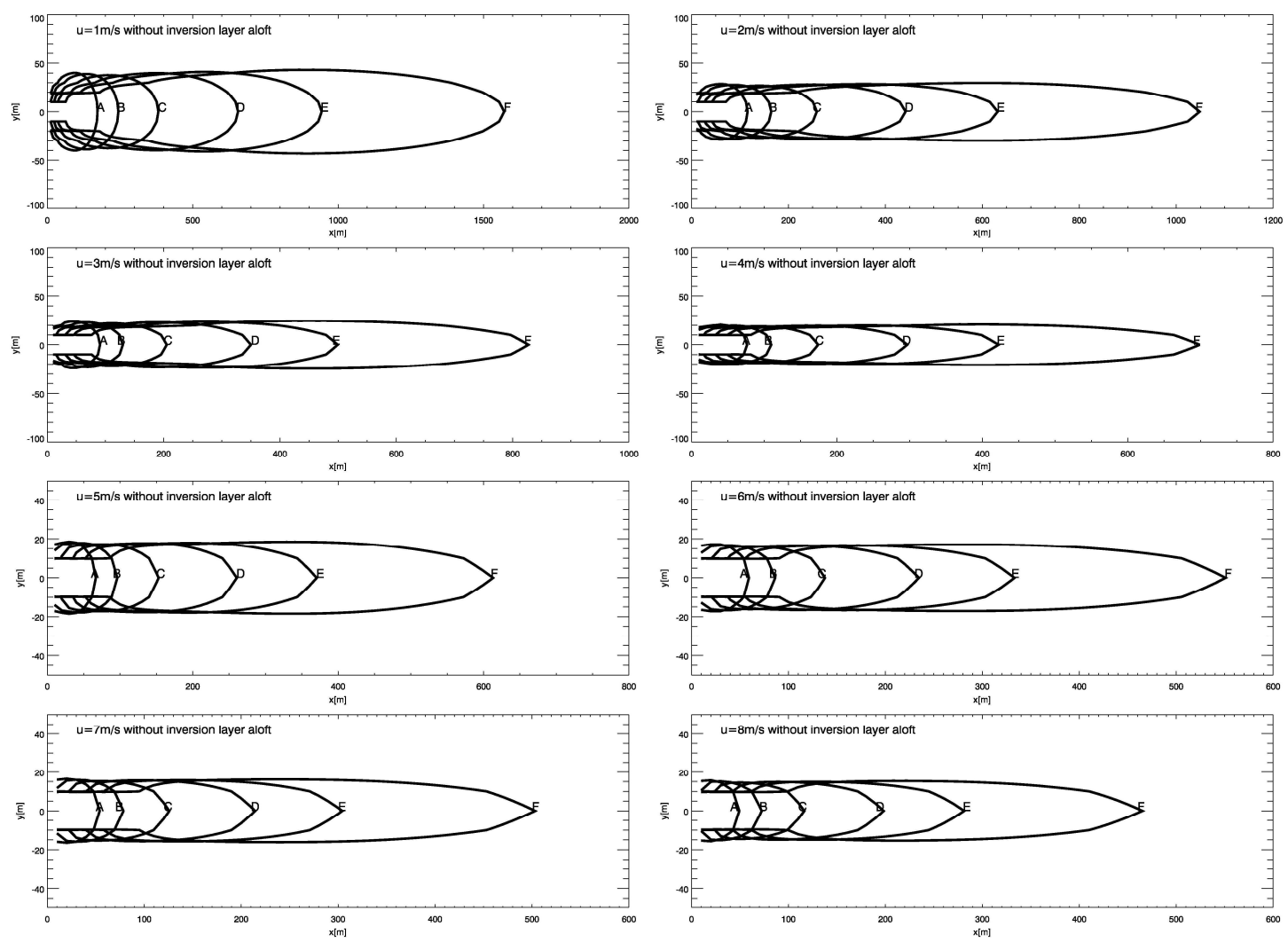

Figure 3. Stack height level $\mathrm{O}_{2}$ plume concentration with different background wind speed under different stability classes. The $\mathrm{x}$-axis is along the prevailing wind direction.

The $\mathrm{O}_{2}$ plume concentration from an $\mathrm{H}_{2}$ plant in a future $\mathrm{H}_{2}$ society estimated based on the series of assumptions and simplifications described above produces typical behaviors as described above. The productivity of an individual $\mathrm{H}_{2}$ plant may be quite different from the case we are studying here. However, one can easily get the desired $\mathrm{O}_{2}$ concentration from this study by scaling the $\mathrm{Q}$ term in the Gaussian plume equation and rescaling the concentrations in each of the plots described for higher or lower values. For example, provided that stability class and background wind speed are the same, if in a real case an $\mathrm{H}_{2}$ plant is emitting $100 \mathrm{~kg} \mathrm{~s}^{-1} \mathrm{O}_{2}$ instead of the $500 \mathrm{~kg} \mathrm{~s}^{-1}$ assumed in this study, then the $\mathrm{O}_{2}$ concentrations in the plots would be reduced by a factor of five. 

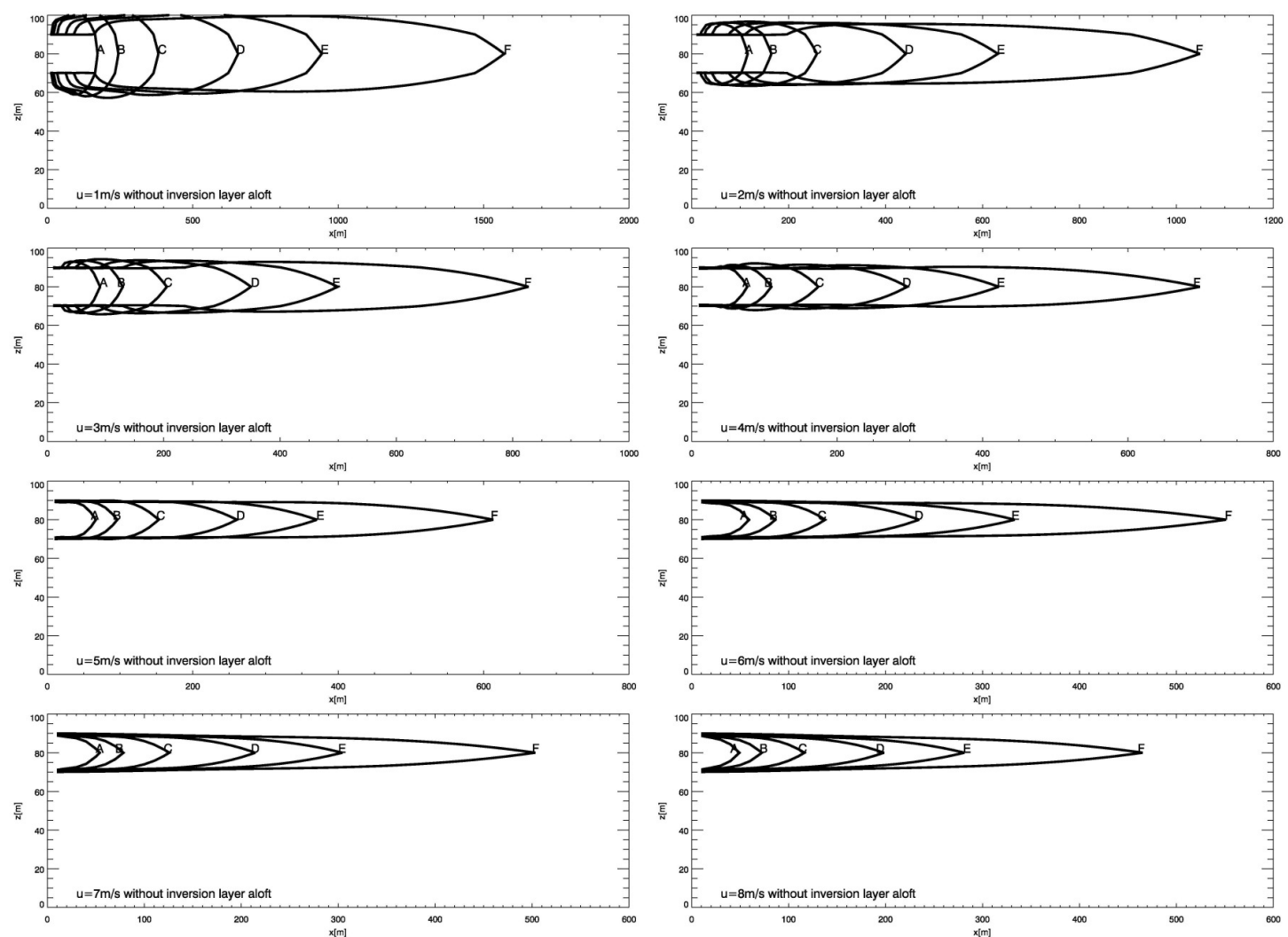

Figure 4. Vertical cross-section $\mathrm{O}_{2}$ plume concentration with different background wind speed under different stability classes. The $\mathrm{x}$-axis is along the prevailing wind direction.

As mentioned before, the Gaussian plume equation is designated to describe a timeaveraged plume. In real case the instantaneous concentration might fluctuate due to atmospheric disturbances. Therefore, the fire hazardous area may be larger than the area bound by the critical lines in this study. Safety regulation makers must bear this in mind. Likewise in a completely stagnant airmass with a velocity of zero the oxygen concentration could easily build up to dangerous levels at the electrolyzer plant itself. 


\section{References:}

- Energy \& Environment Directorate, Lawrence Livermore National Laboratory, http://eed.llnl.gov/flow/02flow.php, June, 2004.

- $\quad$ Bossel, Ulf \& Eliasson, Baldur. Energy and The Hydrogen Economy. January 2003. 


\title{
Section 8 \\ Impact of an $\mathrm{H}_{2}$-Based Road Transportation Sector on Materials and Structures
}

\begin{abstract}
Angus Rockett
The incorporation of elemental hydrogen into almost all metals decreases their ductility greatly and can be a cause of fracture in high hydrogen environments. Therefore the adoption of a hydrogen economy with consequent increases in atmospheric hydrogen is a concern. While any amount of hydrogen represents a potential threat to an engineering/structural metal alloy a key question is whether the level of hydrogen predicted here to be associated with the hydrogen economy, including in localized areas, represents a threat to metal structures.
\end{abstract}

Analysis of the predicted levels of atmospheric hydrogen combined with an extensive theoretical and experimental analysis of hydrogen embrittlement mechanisms in metals shows that the hydrogen economy does not represent such a threat. Under normal conditions, even were hydrogen concentrated in a local area, the incorporation rate of hydrogen into structural alloys is too slow to degrade their properties. This is because metals include a surface oxide layer that is typically somewhat protective for hydrogen incorporation and further that hydrogen in its typical diatomic configuration is relatively unreactive. The necessary decomposition of the diatom as a first step to incorporation in and embrittlement of a metal is slow. Therefore unless a combination of metals is used that can simultaneously catalyze decomposition of the hydrogen molecules and promote incorporation of the resulting atoms into a strongly embrittleable metal, it is highly unlikely that atmospheric hydrogen would represent a threat. Such a catalytic combination is relatively rare and elevated temperatures are normally needed in any case to incorporate hydrogen at a sufficient rate to cause trouble.

The primary concern in a hydrogen economy would be in pressurized storage vessels and pipelines where metals are exposed to high pressures of pure hydrogen for extended times. Knowing this, designs can be adopted and specific metals chosen to reduce or practically eliminate concerns. 
We therefore conclude that hydrogen embrittlement of metals does not pose a threat to structures or devices under normal circumstances. 